\title{
Essays on Comparing Poverty Measures, Gender Differences in Subjective Well-being, Food Insecurity and Malnutrition in Pakistan
}

\author{
Dissertation \\ to obtain the Ph.D. degree \\ in the Courant Research Center 'Poverty, Equity and Growth' \\ At the Faculty of Economic Sciences, \\ Georg-August-University Göttingen, Germany
}

\author{
Presented by \\ Tahir Mahmood \\ Born in Pakistan
}

Göttingen, August 2018 
Name of supervisor: $\quad$ Prof. Xiaohua Yu, PhD

Professor of Agricultural Economics

Courant Research Centre "Poverty, Equity and Growth"

University of Göttingen

Platz der Goettinger Sieben 5, Goettingen, 37073, Germany

Email: xyu@uni-goettingen.de

Name of co-supervisor: $\quad$ Prof. Stephan Klasen, PhD

Professor of Development Economics

Courant Research Centre "Poverty, Equity and Growth"\&

Chair of Development Economics

University of Göttingen

Platz der Göttinger Sieben 3, Göttingen 37073, Germany

Email: sklasen@uni-goettingen.de

Name of co-supervisor: $\quad$ Prof. Dr. Sebastian Vollmer

Professor of Development Economics

(Chair of Development Economics/

Centre for Modern Indian Studies (CeMIS))

University of Göttingen

Platz der Göttinger Sieben 3, Göttingen 37073, Germany

Email: svollmer@uni-goettingen.de

Date of Dissertation: 24-07-2018

(Please fill in the date of dissertation. It is the day before the doctoral celebration, on this day the faculty council makes your grades public) 


\section{$\underline{\text { Acknowledgement }}$}

My Ph.D study is financially supported by AWKUM, Faculty Development Program, Pakistan. I would like to thank them for providing enough stipends for me to stay and study in Germany. First, I wish to thank Prof. Xiaohua Yu for inviting me to study in Göttingen, Germany. I would like to gratefully acknowledge, the enthusiastic supervision, encouragement, guidance and support of Prof. Xiaohua Yu from the initial level to the final level, which enabled me to develop an understanding of the subject. Above all and the most needed, he provided me unflinching encouragement and support in various ways. His truly intuition has made as a consistent oasis of ideas and passions, which exceptionally inspire and enrich my growth as a student and a researcher.

I would like to thank Prof. Stephan Klasen and Prof. Sebastian Vollmer in supervising me and being part of my admission committee and examination committee. I would also appreciate their valuable comments, suggestions, and guidance during my presentations at the Dev. Eco. Seminar and help in my research and career. I would like to thank Jana Nowakowsky for her endless support during my study period. She helped me from the office work to the family affairs. It would never become possible for me to prosecute my studies without mentioning my father (late) desire and love for education.

I am forever indebted to my family for their understanding, endless patience, and encouragement, when it was most required. I am grateful to all my friends and colleagues; Faisal Abbas, Junaid Ahmed, Eva Hasiner, Feifei Sun, Dieter Komle, Farah, Tran Duc Tri, Christoph with whom I spent my studies time and learned a lot from them.

Tahir Mahmood 


\section{Research Papers}

1. Do the Poor really Feel Poor? Comparing Objective Poverty with Subjective Poverty in Pakistan

(Published in Social Indicators Research with Prof. Xiaohua Yu and Prof. Stephan

Klasen). http://link.springer.com/article/10.1007/s11205-018-1921-4

2. He Said, She Said: Unpacking Pakistan's Intra-household Gender Differences in Subjective Well-being

3. What determines food (in)security in Pakistan? New evidence using Food Insecurity Experience Scale Survey Module (FIES-SM)

4. Why under five children are stunted in Punjab, Pakistan? Multilevel analysis of Multiple Indicator Cluster Survey (MICS-2014) 


\section{Table of Contents}

List of Tables ................................................................................................................................................iv

List of Figures...............................................................................................................................................................

List of Abbreviations .....................................................................................................................

Chapter 1 Executive Introduction ...........................................................................................................................1

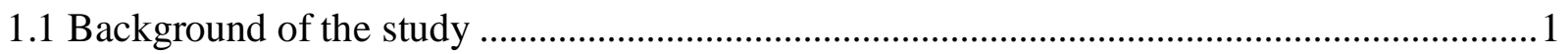

1.2 Poverty scenario and gender differences in Pakistan ............................................................2

1.2.1 Do the poor really feel poor? ......................................................................................

1.2.2 Gender differences in subjective well-being.................................................................5

1.3 Food insecurity and malnutrition scenario in Pakistan ........................................................... 6

1.3.1 What determines food insecurity in Pakistan? ..............................................................6

1.3.2 Why under five children are stunted in Pakistan ............................................................

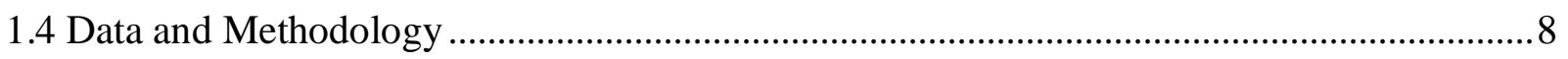

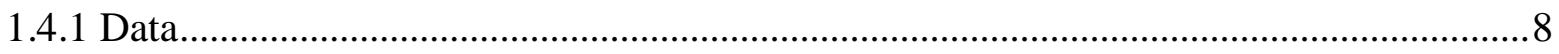

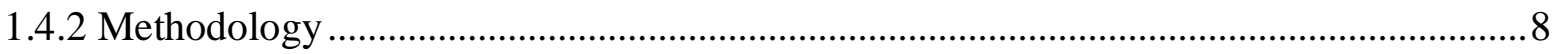

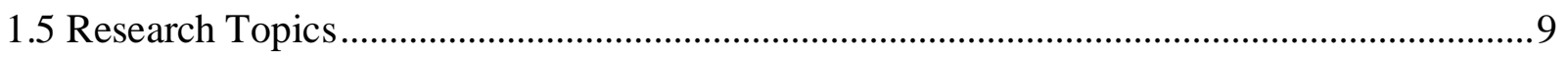

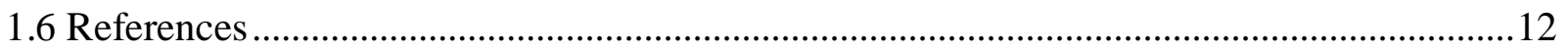

\section{Chapter 2 Do the Poor really Feel Poor? Comparing Objective Poverty with Subjective}

Poverty in Pakistan......................................................................................................................................15

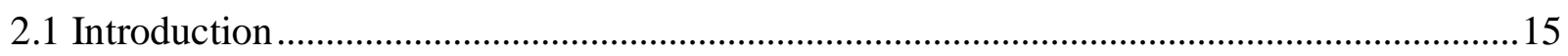

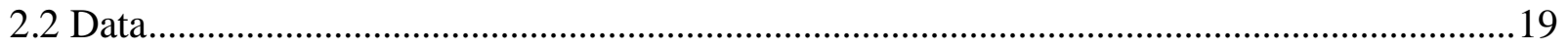

2.2.1 Research design ............................................................................................... 19

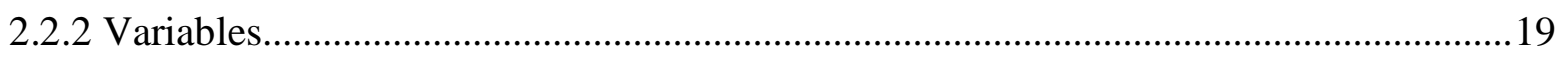

2.2.3 Descriptive statistics ...............................................................................................2

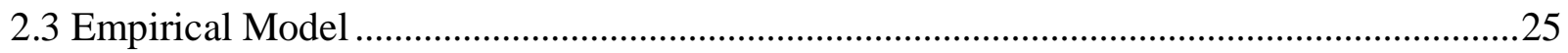

2.3.1 Comparison between subjective poverty and objective poverty ………………….......2

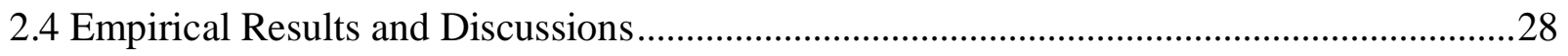

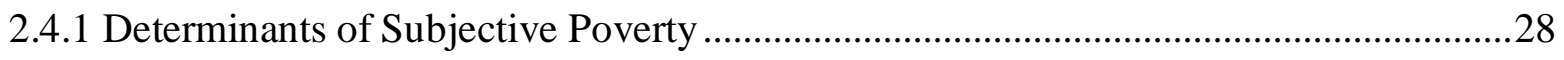

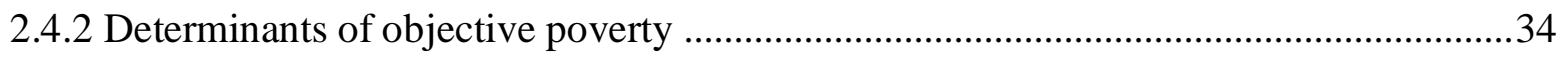

2.4.3 Comparison of subjective poverty with objective poverty …………………..................39 


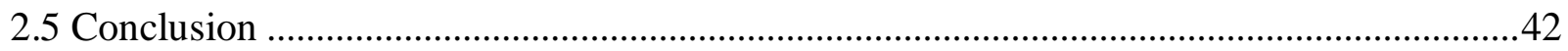

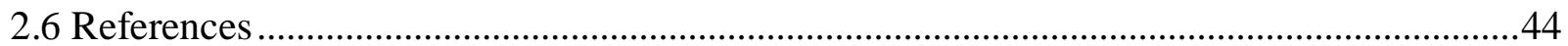

Chapter 3 He Said, She Said: Unpacking Pakistan's Intra-household Gender Differences in

Subjective Well-being..............................................................................................................51

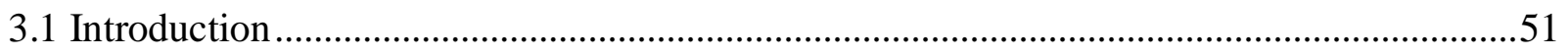

3.2 Data, hypothesis and variables.......................................................................................54

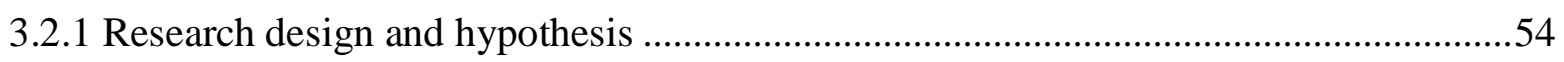

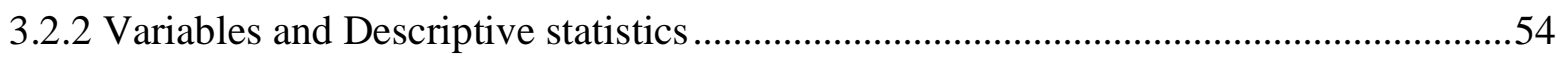

3.2.3 Descriptive statistics ...............................................................................................5

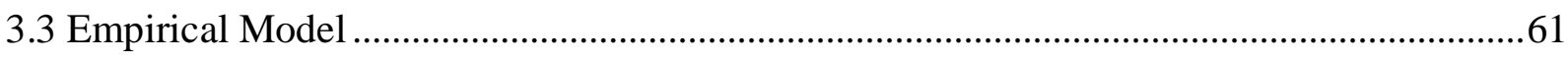

3.3.1 Comparison between male and female subjective well-being........................................62

3.4 Empirical Results and Discussion .................................................................................63

3.4.1 Determinants of male and female subjective well-being ...............................................63

3.4.2 Gender difference in the determinants of subjective well-being ....................................68

3.5 Conclusion and policy recommendations ……………………………………………….....74

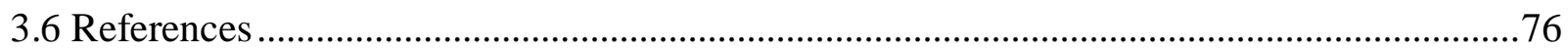

Chapter 4 What determines food (in)security in Pakistan? New evidence using Food

Insecurity Experience Scale Survey Module (FIES-SM)...........................................................81

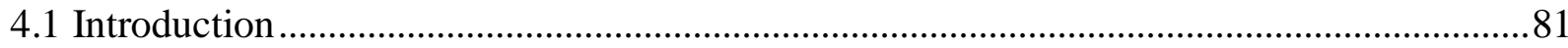

4.2 Data design, hypothesis, variables, and descriptive statistics ................................................ 84

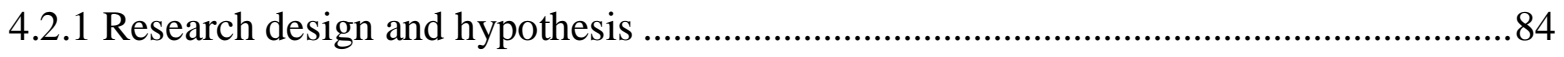

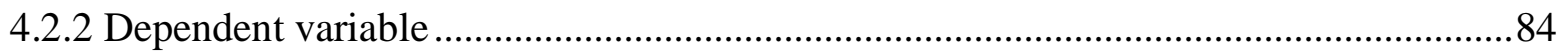

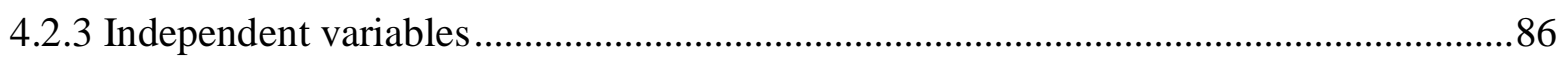

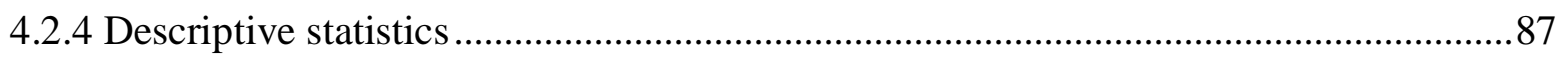

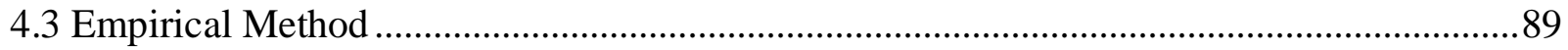

4.4 Empirical Results and Discussions ................................................................................91

4.5 Conclusion and Policy Recommendations.............................................................................

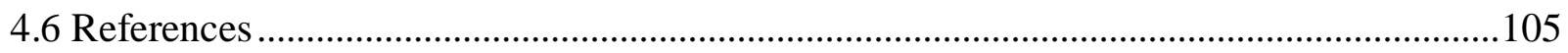

Chapter 5 Why under five children are stunted in Punjab, Pakistan? Multilevel analysis of Multiple Indicator Cluster Survey (MICS-2014)......................................................................110 


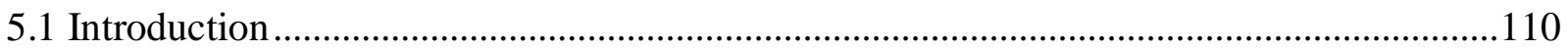

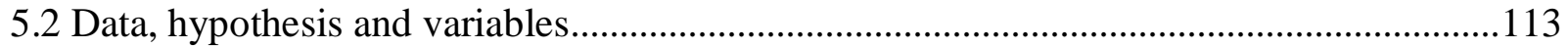

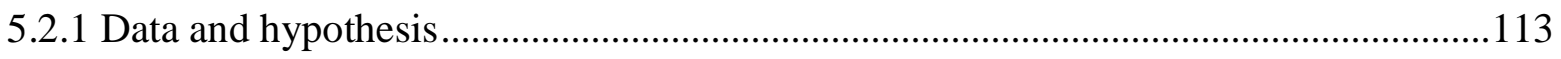

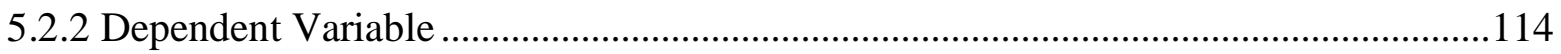

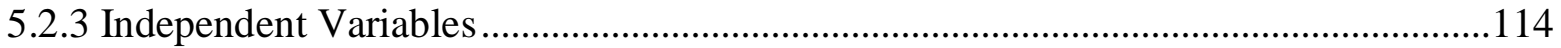

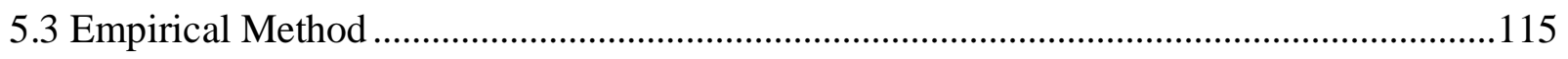

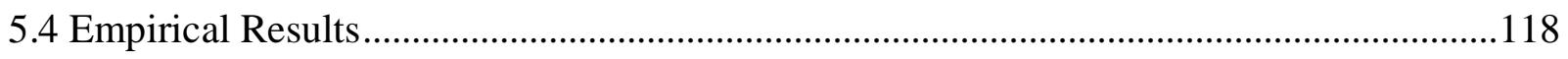

5.4.1 Bivariate Analysis Results .......................................................................................118

5.4.2 Multivariate Analysis Results .................................................................................. 121

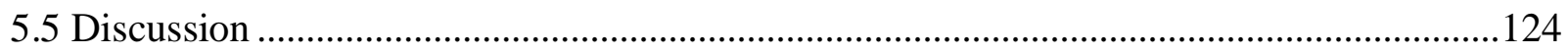

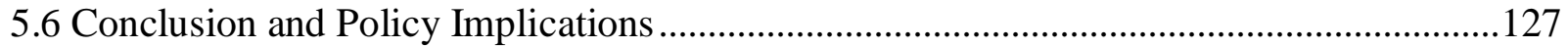

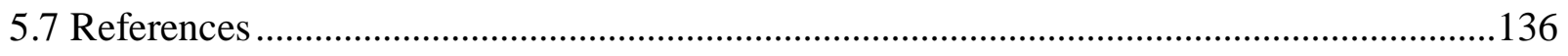

Chapter 6 Conclusion and Policy Recommendations ..............................................................................142 


\section{List of Tables}

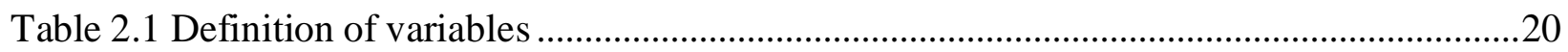

Table 2.2 Demographic and socio-economic characteristics of households ...................................22

Table 2.3 Descriptive Statistics of Subjective Poverty in Pakistan ................................................24

Table 2.4 Aggregate poverty measures $1 \$, \$ 1.25$ and $\$ 1.9$ per person per day (objective poverty)

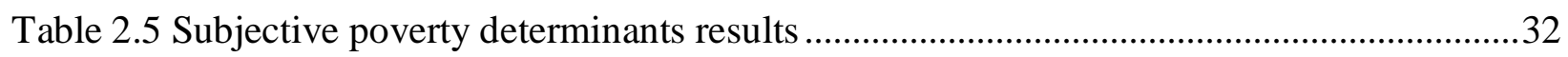

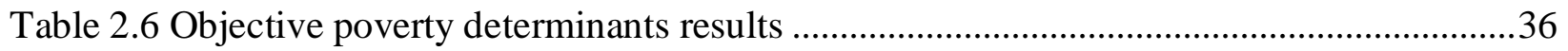

Table 2.7 Comparison of subjective poverty and objective poverty $(\$ 1.25) \ldots \ldots \ldots \ldots \ldots \ldots \ldots \ldots \ldots \ldots \ldots . . . .40$

Table 2.8 Spearman's correlation matrix …………………........................................................42

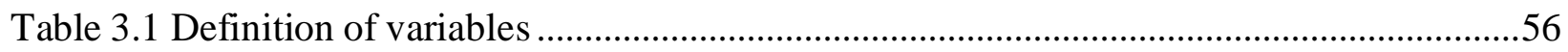

Table 3.2 Demographic and socio-economic characteristics of household ...................................58

Table 3.3 Descriptive Statistics of Subjective Well-being in Pakistan ...........................................59

Table 3.4 Correlation matrix of both male and female subjective Well-being.................................60

Table 3.5 Order Probit models estimation results ..........................................................................67

Table 3.6 Robust linear regression and multinomial models estimation results .............................71

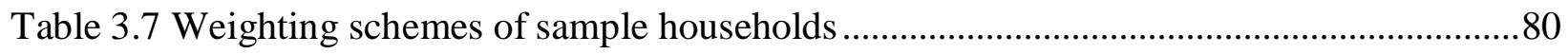

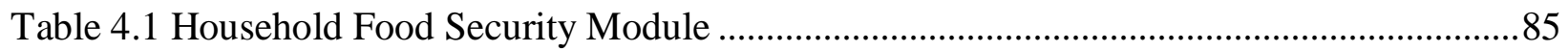

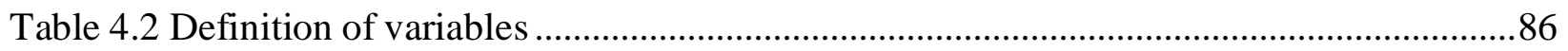

Table 4.3 Weighting schemes of sample households ..................................................................... 87

Table 4.4 Descriptive statistics of Food Insecurity Experience Scale (FIES) in Pakistan..............88

Table 4.5 Correlation matrix of food insecurity experience scale (FIES) ......................................8

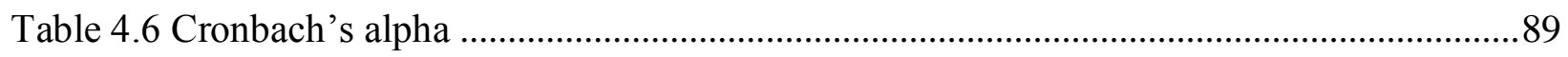

Table 4.7 Results of ordered probit model, probit model and linear probability models ..............99

Table 5.1 Prevalence of moderate and severe childhood stunting at various levels of independent variables in Punjab, Pakistan (Punjab MICS-2014) .........................................................119

Table 5.2 Multivariable Regression results of Multilevel Models Punjab (MICS-2014)............128

Table 5.3 Multivariable Regression results of Multilevel Models Punjab (MICS-2014)............131 Table 5.4 Description of the Variance Partition Coefficient (VPC) and Intra Class Correlation

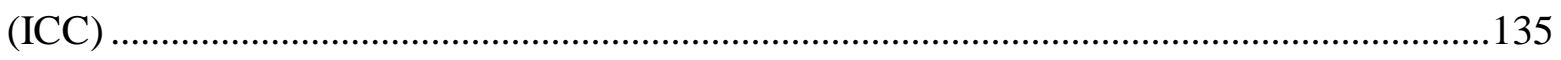




\section{List of Figures}

Figure 2. 1 Relationship between per capita expenditure and subjective well-being...........47

Figure 3.1 Gender differences in subjective well-being.............................................................55

Figure 4. 1 Relationship between food security and poverty ....................................................93

Figure 4. 2 Relationship between food security and inflationary shocks....................................97

Figure 4. 3 Relationship between income (poverty) and food insecurity ...................................109

Figure 4. 4 Relationship between food security and poverty....................................................109 


\section{List of Abbreviations}

\begin{tabular}{|c|c|}
\hline AIDS & Acquired Immune Deficiency Syndrome \\
\hline ANT & Antenatal Care \\
\hline D.G. Khan & Dera Ghazi Khan \\
\hline EB & Enumeration Block \\
\hline DHS & Demographic and Health Survey \\
\hline $\mathrm{FAO}$ & Food and Agriculture Organization \\
\hline FEI & Food Energy Intake \\
\hline FIES & Food Insecurity Experience Scale \\
\hline FIES-SM & Food Insecurity Experience Scale Survey Module \\
\hline FII & Food Insecurity Index \\
\hline GHI & Global Hunger Index \\
\hline GTD & Global Terrorism Database \\
\hline GWP & Gallup World Pool \\
\hline HAZ & Height for Age \\
\hline HIES & Household Integrated Economic Survey \\
\hline HIV & Human Immunodeficiency Virus \\
\hline ICC & Intra Class Correlation \\
\hline IEQ & Income Evaluation Question \\
\hline IFPRI & International Food Policy Research Institute \\
\hline ILO & International Labor Organization \\
\hline $\mathrm{KP}$ & Khyber Pakhtunkhwa \\
\hline LPM & Linear Probability Model \\
\hline MICS & Multiple Indicator Cluster Survey \\
\hline MIQ & Minimum Income Question \\
\hline NNS & National Nutrition Survey \\
\hline OBI & Old age Benefit Institution \\
\hline PBM & Pakistan Bait UL Mal \\
\hline PBS & Punjab Bureau of Statistics \\
\hline PCA & Principal Component Analysis \\
\hline PCV & Proportional Change in Variance \\
\hline PDHS & Pakistan Demographic and Health Survey \\
\hline PFDs & Provincial Food Departments \\
\hline PIDE & Pakistan Institute of Development Economics \\
\hline PPAF & Pakistan Poverty Alleviation Fund \\
\hline PPHS & Pakistan Panel Household Survey \\
\hline PPP & Purchasing Power Parity \\
\hline PSLM & Pakistan Living Standard and Measurement \\
\hline PSUs & Primary Sampling Units \\
\hline $\mathrm{R} \& \mathrm{D}$ & Research and Development \\
\hline SDC & Swiss Agency for Development and Cooperation \\
\hline
\end{tabular}




$\begin{array}{ll}\text { SDG2 } & \text { United Nations Sustainable Development Goal } 2 \\ \text { SDPI } & \text { Sustainable Development Policy Institute } \\ \text { SSUs } & \text { Secondary Sampling Units } \\ \text { SUN } & \text { Scaling Up Nutrition } \\ \text { UNDP } & \text { United Nations Development Program } \\ \text { UNICEF } & \text { The United Nations International Children's Fund } \\ \text { USDA } & \text { Unites States Department of Agriculture } \\ \text { VoH } & \text { Voice of Hungry } \\ \text { VPC } & \text { Variance Partition Coefficient } \\ \text { WASH } & \text { Water, Sanitation, and Hygiene } \\ \text { WFP } & \text { World Food Program } \\ \text { WHO } & \text { World Health Organization } \\ \text { WWF } & \text { Workers Welfare Funds }\end{array}$




\section{Chapter 1 Executive Introduction}

\subsection{Background of the study}

Poverty, food insecurity, and malnutrition are some of the pressing challenges of the world. Poverty is more than the lack of income and resources to ensure a sustainable livelihood. Its manifestations include hunger, malnutrition, and limited access to education, social discrimination, and lack of participation in decision-making. Globally, one in ninth people today (815 million) are undernourished. One in four of the world's children suffer stunted growth (World Bank 2015). Food insecurity is clearly related to poverty and could even be thought of as a subset of poverty. Nutrition security depends not only on adequate food security but also on adequate care practices and adequate health. However, poverty and malnutrition can have nonfood determinants or manifestations. While these terms are often use interchangeably, each of these dimensions are distinct from each other conceptually. One closely related issue with these dimensions is the intra-household gender differences. Unfortunately, Pakistan has performed poorly on these dimensions. Therefore, the empirical analyses of these pressing issues are the basic motivation of the study. Recent approaches to international development policy stress the growing importance of these crosscutting themes and social issues.

Pakistan is a lower middle-income country with a population of 207.7 million ranked sixth in the world (Pakistan Census 2017). Since 1947 Pakistan's economic growth continue to grow particularly per capita increase of about 2 percent over a long period of fifty years despite fourfold increase in the population. However, Pakistan has lost economic ground to rapidly growing economies of Asia particularly South East Asia. Moreover, agriculture is the backbone of the economy. Pakistan's agriculture sector presents enormous potential for growth through increased productivity. During the financial year 2017, the agriculture sector contributed 19.5 percent in gross domestic product (GDP) and it employs 42.3 percent of the country's total labor force, constitutes 65 percent of export earnings, provides livelihood of 62 percent population and raw materials for many value added industries. The industrial sector contributes 20.88 percent in GDP, while the services sector has the highest contribution of about 60 percent. The per capita income in dollar term is 1629 in fiscal year 2017. The estimated population growth and fertility is 1.86 and 3 respectively (Economic Survey 2016/17). 
Moreover, despite the relative high economic growth Pakistan is lagging behind in many social development indicators. Be it, education, nutrition, health, food security, well-being, or gender equality, spends much less as a percentage of GDP than many developing countries. For example, the Human Development Report ranks Pakistan at $147^{\text {th }}$ out of 188 countries under the Human Development Index (HDI) based on education, health and national income per capita (UNDP 2016). ${ }^{1}$ The multidimensional Poverty Index stands at 0.197 based on Pakistan Living Standards Measurement Survey (2014/15). Using the same data the multidimensional poverty head count ratio was estimated at $38.8 \%$ of the population. Similarly, the latest National nutrition Survey (NNS) conducted in 2011 report shows that 44 percent of children below five years of age are stunted, 32 percent are underweight, followed by 15 percent wasted. According to World Food Program (WFF), about 60 percent of the people are food insecure. Hence, this research focuses on the pressing problems that are comparing poverty measures, gender differences, food insecurity, and malnutrition.

Therefore, the main motivation of the study is to analyze the determinants of both subjective and objective poverty and comparing the monetary measure of poverty with subjective poverty to better formulate and implement poverty alleviation policy. Similarly, it is also important to explore the determinants of gender differences in well-being and malnutrition, particularly stunting is one of the acute undernutrition problem in Pakistan. Equally important are the food insecurity problem faced by the majority of the poor segment of society. Importantly poverty, malnutrition, and food insecurity are inter-related and have been driven by each another. The following are the main objectives of this dissertation. First, fill the research gap of poverty measures and determine who are actually poor. Second, explore gender differences in subjective well-being. Third, investigate the determinants of food insecurity. Fourth, analyze the determinants of malnutrition at household, community, and district level. More details are discussed in the next subsections.

\subsection{Poverty scenario and gender differences in Pakistan}

Poverty has become one of the central issues of the world. Pakistan is no exception. According to Multidimensional Poverty report 2016, poor are predominantly rural, young, less educated, less access to health facilities, large household size and more children. The government of Pakistan

\footnotetext{
${ }^{1}$ Pakistan's HDI value is 0.550 , out of 1 as against South Asia's average HDI value of 0.621 and world's average value of 0.717 .
} 
vision 2025 "No one left behind" is in complete consonance with Sustainable Development Goals (SDGs), however, it poses challenges of eradicating poverty in all its dimensions. In this context, Social Safety Nets (SSN) is working to mitigate the menace of poverty. They have started social safety nets programs such as cash transfer, in-kind transfer, food, and school feeding programs, social pension to provide access to essential services such as education, health, housing, and food security. Specifically, Benazir Income Support Program (BISP) is the largest single cash transfer program in Pakistan. ${ }^{2}$

Similarly, Pakistan Poverty Alleviation Fund (PIAF) an apex organization also supports the government social protection programs by providing a poverty graduation approach for the poorest households. It assists very poor households to left them out of poverty. ${ }^{3}$ In addition, Zakat and Pakistan Bait-Ul-Mal (PBM) funds are making significant contribution in alleviation of poverty. ${ }^{4}$ In the same manner, Workers Welfare Funds (WWF), Employees Old age Benefit Institution (OBI) and Micro finance network play an important role in the eradication of poverty. The long-term objectives are to eradicate extreme and chronic poverty and women empowerment.

However, challenges are in the implementation of these programs that include; in setting up the eligibility criteria, how to measure poverty, how to identify who are actually poor, how to introduce the poverty scorecard given the scarcity of the resources and supply-demand gap. To this end, first, we compare the objective poverty with subjective poverty and its determinants analysis.

Similarly, Millennium Development Goal 3 is to promote gender equality and empower women. Women represent a staggering higher percentage of the world's poor. Women and men have different access to resources within the households. Data from households may reveal hidden discrimination according to age, gender, and economic opportunities. In order to design appropriate Poverty Reduction Strategies, there is need to consider the individual status within a household because men and women experience poverty in different ways. With poverty

\footnotetext{
${ }^{2}$ The quarterly cash transfer has increased over the years to Rs. 4834/- per family in fiscal year 2016-17. The number of beneficiaries has increased from 1.7 million in 2009 to 5.42 million in 2017. Its annual disbursement increased from Rs. 16 billion in 2009 to Rs. 115 billion in 2017

${ }^{3}$ The PPAF provide supports in projects such as social inclusion-gender, environment, infrastructure, health and education, livelihood, and microfinance.

${ }^{4}$ A total amount of Rs. 7570 million zakat funds and Rs. 2183 million Bait-u-Mal funds have been distributed in fiscal year 2017 .Zakat funds are used for the assistance to needy, poor, indigent, orphans, widows, handicapped, and disabled. Similarly, the Bait-ul-Mal provide assistance to destitute, widows, invalid, infirm and needy persons as per eligibility criteria.
} 
reduction embodied in the UN Millennium Declaration as an overarching development objective, the fact that women are disproportionately affected by extreme poverty and Pakistan is no exception. Using data from a UN DHS (2012-13) report reveals that 12 percent of women in Pakistan (4.9 million) of age 18-49 are simultaneously deprived in four sustainable development Goals related dimensions (child marriage, education, health care and employment). Food insecurity is at a staggering 11 percent higher among women (UN 2017).Therefore, we investigate gender differences in subjective well-being in unpacking the factors that cause these differences at micro level. The following two subsections describe poverty comparison and gender differences separately.

\subsubsection{Do the poor really feel poor?}

Poverty is a multidimensional phenomenon, which encompass not only monetary deprivation, but also include limited access to health care, education and other social benefit deprivation for all communities across the country. The most critical question related to poverty is how to set poverty threshold? Should we need to focus only on economic factors or we also need to include non-economic factors that defines poverty? Whether the measurement of poverty should be based on objective measure such as calorie, basic needs, food security, or accessibility. Alternatively, should we use the different subjective dimensions of poverty? For example, in contrast to objective poverty measures, the subjective poverty measure is also important measures of poverty such as we have poverty measures based on life satisfaction and happiness (Stevenson and Wolfers 2013; Kingdon and Knight 2006; Zhou and Yu 2017; Shams 2014), and economic position (Riffault 1991; Ravallion and Lokshin 2002). Actually, these measures complement the conventional measures, as poverty is multidimensional, and vary from country to country, as well as depend on the specific circumstances of the country.

To compare poverty across countries $\$ 1.9$ per day poverty threshold is used (World Bank 2015). Nevertheless, most countries have their own poverty measures to inform their policy makers. Hence, it is very important to develop such a national poverty measures that should be related to specific national circumstances but also incorporates the multi-faced nature of poverty. To this end this paper; compare the objective poverty with subjective poverty, to draw inferences about the determinants that will help in the development of national version of poverty measures that reflect their own development plan, data sources, and aspirations. In order to fulfill the gap between the economic development and social development, this micro level study may be used 
as a tool to target the inequalities and eradicate poverty in its entire dimensions. It also recommends that it is not safe to use one measures of poverty.

\subsubsection{Gender differences in subjective well-being}

In changing global economic scenario, gender sensitive development strategies are an integral part of economic and social development. Importantly, gender discrepancies arise due to socioculture factors and institutional support discrimination in terms of access to education, health, nutrition, land, and labor markets. In this study, we are interested to describe and analyze the determinants of the same household, on what factors male and female respond differently to their economic position. The gender aspect here is that contributions are in general unequal distributed by gender that is men employment has found to be more important than women (Mies 1982). Similarly, studies have shown that men and women have different perception about their contribution, with women more aware of the tension between supposedly joint and individual interests (Bennett et al. 2012).

The rationale for including the gender perspective explicitly in the policies is that female experience well-being differently, because of different needs, options, incentives, and constraints. A full understanding of gender dimension is inevitable because gender inequalities are leading to inefficient economic outcomes (Bamberger et al. 2002). Given that both members within household are assessing the same question, it is reasonable to envisage if that their affirmative responses about subjective economic position differ then it would cause gender differences in subjective well-being relatively. Specifically, Kalugina et al. (2009), use Russian data to estimate spouses' relative shares by the difference in how they positioned themselves on a societal poor- rich ladder, the finding concludes a significant spousal wage differences. Similarly, Bonke and Browing (2009) utilize cross sectional Danish data, interpreted answers to a question on satisfaction with regard to present financial situation, indicating respondents' level of material well-being generally and their consumption in particular. Hence, a full understanding of gender dimension of well-being can change significantly the policy makers on priority basis and programs related to poverty reduction strategy in developing countries. 


\subsection{Food insecurity and malnutrition scenario in Pakistan}

The World Food Summit 1998 defined food security as "when all people at all times have physical and economic access to sufficient, safe, and nutritious food to dietary needs and food preferences for an active and healthy life". Pakistan has experienced rise in food insecurity during the last decade owing to conflicts, natural disasters, and economic instability. Pakistan has ranked $11^{\text {th }}$ worst among 118 countries in the Global Hunger Index (2016). The latest National nutrition Survey (NNS) conducted in 2011 report shows 44 percent of children below five years of age are stunted, 32 percent are underweight, followed by 15 percent wasted. Based on Household Integrated Economic Survey (2013/14), the average daily household calorie consumption per adult equivalent is 2033 calorie, which is 13 percent less than the officially recommended level of 2350 calories. Similarly, average calorie consumption of households are 1570 for the poorest quintile, well below the recommended threshold by 23 percent. Furthermore, for urban households, it is 10 percent lower than the urban households are (World Bank, 2016a). Cereals are important source of calories, out of which 60 percent of poorest calories come from cereals. Among cereals, wheat is the most important source of calories followed by rice. However, cost of calorie from wheat is higher for poor than non-poor households. The cost of food rose significantly from 2001 to 2013 by 270 percent compared to 180 percent nonfood prices (World Bank, 2016a).

According to Food and Agriculture Organization (FAO) report daily per capita calorie fluctuated between 2200 and 2400 calories since 1970s. The average daily calorie consumption per adult equivalent declined from 2228 to 2033 between 2002 through 2014 (World Bank, 2016a). Pakistan allocates about 1 percent of its total budget toward nutrition-related programs compared to an average of 2 percent for a sample of 24 developing countries. Hence, it is imperative to find out what are the major determinants of food insecurity and malnutrition.

\subsubsection{What determines food insecurity in Pakistan?}

Food security is a multidimensional phenomenon, which surrounds different regional, community and household level factors. However, common accepted metric to measure the determinants of food insecurity across different countries has so for been lacking. For example, the conventional model-based estimates are inconsistent (Barret 2010; Masset 2011; Klasen 2008; Svedberg 2002). Food insecurity is ubiquitous as more than 800 million people are undernourished across the globe (FAO, 2014). Moreover, food insecurity on the rise in 
developing countries, even though production double during the last three decades to meet the rising demand of food (FAO, 2009). Furthermore, globally, hunger and malnutrition has decline but food security is still a challenge to be secured. In recent years, Pakistan has become a food surplus country, particularly major producer of wheat and rice. Despite this tremendous growth, the poor and vulnerable segment of society cannot afford sufficient and nutritious food. According to World Food Program (WFP), about 60 percent of the people are food insecure and malnutrition is ubiquitous.

Using NNS (2011) data, Di Cesare et al. (2015) find that household food insecurity measured by household food security survey module, is negatively associated with height for age (HAZ), weight for age (WAZ) and weight for height (WHZ). Numerous other studies have used experiential food insecurity scales over the past decades such as (Coates et al. 2003; Coates et al. 2006; Webb et al. 2006; Frongillo and Nanama 2006; Nord 2012; Smith et al. 2017a; Smith et al. 2017b). Hence, in our study, we will explore the determinants of food insecurity at micro level. This study will fill the existing the research gap, while also draw inferences about food insecurity, poverty and inflation.

\subsubsection{Why under five children are stunted in Pakistan}

Malnutrition is a complex phenomenon ranging from undernutrition owing to deficiencies in energy, proteins, and micronutrients to problems of overweight and obesity in Pakistan. According to Scaling Up Nutrition (SUN) more than 177,000 children under five die annually due to their or their mother' malnutrition. ${ }^{5}$ The latest National nutrition Survey (NNS) conducted in 2011 report shows 44 percent of children below five years of age are stunted, 32 percent are underweight, followed by 15 percent wasted in Pakistan. The report also delineates that 54 percent are deficit in vitamin A, 39 percent are deficit in zinc, 40 percent are deficit in vitamin D, 44 percent are deficit in iron, and 62 percent are anemic. Similarly, 51 percent of pregnant women are anemic, 46 percent are deficit in vitamin A, 69 percent are deficit in vitamin D, and 59 percent are deficit in calcium. Moreover, ongoing conflicts and violence coupled with largescale displacement, recurrent natural disasters, and economic instability has exacerbated the prevailing food insecurity situation and has retarded the livelihood opportunities.

\footnotetext{
${ }^{5}$ Pakistan Scaling Up Nutrition (SUN) Secretariat at the Ministry of Planning Development and Reform (MPDR), done in collaboration with the United Nations World Food Programme (WFP).
} 


\subsection{Data and Methodology}

\subsubsection{Data}

We use three types of data sources in our analysis. For poverty, gender differences and food insecurity paper we use third round Pakistan Panel Household Survey (PPHS) 2010, a joint project of Pakistan Institute of Development Economics (PIDE) and World Bank. The sample size is 4142 households covering four provinces of which 2800 are rural and 1342 urban households. The PPHS covers a wide range of issues such as population size, poverty, education, employment, health, nutrition, food insecurity, housing, and well-being. For malnutrition paper, we utilize MICS Punjab, 2014. The Multiple Indicator Cluster Survey (MICS) is an international household survey program developed by UNICEF. It collects statistically sound, internationally comparable estimates of more than one hundred and twenty five key indicators that are used to access the situation of children and women in Punjab, Pakistan. The total sample size is 41,000 households, and the analysis consists of 25067 children under five year of age.

\subsubsection{Methodology}

This dissertation mainly employs qualitative response models and its application in different socio-economic problems such as poverty, gender differences, and malnutrition and food insecurity. Qualitative response models constitute a class of regression used to predict the results in one of a discrete number of mutually exclusive outcomes. The models considered in the analysis are the linear probability model, a probit model, an ordered probit model, the multinomial probit model depending on the nature of economic behavior governing the response and on the objective of the analysis. Qualitative variable may be binomial (yes/no), multinomial response may be ordered or unordered. The Maximum Likelihood estimation is utilized where we want to maximize the total probability of the data.

However, for stunting paper we use three level random intercept hierarchical models. Where the households (level 1) are nested within communities (level 2) and communities are nested within districts (level 3). It is important to incorporate three level structures, because we expect a substantially higher level of variance among the three levels on the response variable under study. Furthermore, incorrectly modeling the dependency in the data likely to obtained biased standard error for the predictor variable. (Higher level needs different policies, practices, context and compositional effects). 
In the first paper, we use ordered probit model to highlight the determinants of both objective poverty and subjective poverty, probit model as robust check and multinomial probit and spearman's rank model for the comparison of objective poverty with subjective poverty. Similarly, in the second paper, we use ordered probit model to find out the determinants of male and female subjective well-being and robust linear regression for unpacking gender differences in well-being and multinomial model as robust check. For the paper of food insecurity, we utilize the ordered probit model and probit model and linear probability model as robust check. Multilevel random intercept three level hierarchical models are used to investigate the stunting at household, community and district level.

\subsection{Research Topics}

The empirical analysis highlights several important stylized facts. Chapter 2 through 5 analyses the comparison of objective and subjective poverty, gender differences in subjective well-being, determinants of food insecurity and malnutrition in Pakistan, respectively. Finally, Chapter 6 concludes and suggests policy recommendations.

Chapter 2 investigates the comparison of monetary metric of poverty measure with subjective measure of poverty. The current literature on poverty focuses intensively on objective poverty based on household income, household consumption, basic needs, calorie intake, or a multidimensional poverty approach. In contrast, this paper researches subjective poverty, which is compared with objective poverty measured by income in Pakistan. We find that the determinants of subjective poverty (feeling poor) are not limited to household consumption, but include household size, household demographic structure, agriculture land ownership, sanitation facility, physical, and food insecurity.

In comparison with the overall non-poor, the objective poor and the subjective poor households are determined by different factors. Particularly, subjectively below the poverty line household with higher education, household size, own residence and physical security have a significant positive impact on the eradication of poverty relative to overall non-poor. In addition, the Spearman Rank test upholds that subjective poverty measure complements the conventional method. Thus, priority should be given to specific targeted determinants, which are more important in the alleviation of poverty, while making and implementing public policy given the limited available resources. 
Chapter 3 analyzes the gender differences in subjective well-being. Numerous studies explore gender differences in welfare economics and its implications for economic development. We use a new procedure to estimate gender differences within households by comparing affirmative responses about the respective economic position of a male - female couple. Given that both members within the household respond to the same question, it is deemed reasonable for it to envisage the difference of opinion about the respondent's relative economic position implying gender differences in subjective well-being.

We find that the determinants of subjective well-being of male and female are not limited by household consumption, but also include household's demographic structure, agricultural land ownership, sanitation and physical and food insecurity. Similarly, gender difference in subjective well-being is associated with gender specific access to goal relevant resources. Particularly, food insecurity imparts double negative impact on women subjective well-being whereas physical insecurity is mainly concerned with male subjective well-being. As a robust check, the multinomial model results are consistent with the preceding findings. Finally, the link test statistic and diagnostic results confirm that the models are well-specified. Since the gender response to subjective well-being does not completely overlap; hence, establishing the existence of different policy responses to subjective well-being. We conclude that it is not safe to gauge well-being from one dimension only.

Chapter 4 investigates the important determinants of food insecurity. The available literature on food insecurity measures focuses intensively on calories available per capita at the national level (FAO), household income and expenditure procedures, individuals' dietary intake, anthropometry, and recently developed method by Food and Agriculture Organization (FAO), the so-called experience based food insecurity measurement scales. However, to our best knowledge, limited studies are available for the case of Pakistan. Accordingly, we are using food insecurity experience scale, originally adopted in the US, similar tools followed in various part of the world incorporating quantitative, qualitative, psychological, and social dimension of food security. we find that the determinants of food insecurity are not limited by household consumption, but also affected by household size, household demographic structures, agriculture land ownership, borrowing, natural shocks, violence and inflation. In addition, the linear probability model results are in line with the aforementioned findings. Moreover, the link test result confirms that all the models utilized in the analysis are well specified. In conclusion, 
priority should be given to specific targeted determinants that are more important in the alleviation of food insecurity, while making and implementing public policy given the limited available resources.

Chapter 5 deals with analyzing the determinants of malnutrition in Pakistan. Pakistan is facing an acute problem of child under-nutrition as about 45 percent of children in Pakistan are stunted and in Punjab, the largest province by population and GDP share having stunting prevalence of about 33 percent. In addition about $27 \%$ moderately and $10 \%$ severely stunted children of less than five years in Punjab. To this end, keeping in mind the nature of cluster effect in our data we employ multilevel random intercept model utilizing MICS, 2014 data which consists of 25065 under five years of children. The primary objective of the study is to examine empirically the determinants of stunting at different level of hierarchy. The $L R$ test favored the multilevel logistic regression instead of conventional logistic regression. The unconditional model VPC and ICC statistics show high degree of variability at the household, community and district level. However, majority of the variation in stunting both moderate and severe lies at the household level. The conditional model results indicate strong predicting power of explanatory variables. The household level variation increases, while at the community and district level it declines when control for explanatory variables. Particularly, the district level variation declines by more than 95 percent indicating that almost all variation in stunting is explained by explanatory variables at district level, while at household level the variation increases. This reveals that there exist an acute income inequality, access to health care facility, food insecurity, and opportunities deprivation at household level.

Moreover, the results depict that increasing age of child, increasing birth order of the child, illiterate mothers and fathers, lack of sanitation facilities and being poor wealth status are associated significantly with moderate and sever stunting. The smaller the size of the child at birth it is highly likely (2.5 times) that the child is stunted. Surprisingly, there is a gender bias in stunting in Punjab and being girl child is associated with moderate and severe stunting which depicts the patriarchal nature of the society and a strong prevalence of gender bias in household resource allocations in Pakistan. This outcome of our analysis points towards targeting not only individual children but also their families and communities they are living in. 


\subsection{References}

Bamberger, M., M. Blackden, L. Fort, V. Manoukian, (2002), "Gender", Chapter 10, in A Sourcebook for Poverty Reduction Strategies, vol 1: Core Techniques and Cross-Cutting Issues, by Jeni Klugman (editor), World Bank, Washington, D. C.

Barrett, C. B. (2010). Measuring food insecurity. Science, 327(5967), 825-828.

Bennett, F., De Henau, J., Himmelweit, S., Sung, S. (2012). Financial togetherness and autonomy within couples. Gendered lives: Gender inequalities in production and reproduction, 97-122.

Bonke, J., Browning, M. (2009). The distribution of financial well-being and income within the household. Review of Economics of the Household, 7(1), 31-42.

Coates, J., Webb, P., Houser, R. (2003). Measuring food insecurity: going beyond indicators of income and anthropometry. Food and Nutrition Technical Assistance Project, Academy for Educational Development.

Coates, J., Wilde, P. E., Webb, P., Rogers, B. L., Houser, R. F., (2006). Comparison of a Qualitative and a Quantitative Approach to Developing a Household Food Insecurity Scale for Bangladesh. J. Nutr. 136, 1420S-1430S.

Di Cesare, M., Bhatti, Z., Soofi, S. B., Fortunato, L., Ezzati, M., \& Bhutta, Z. A. (2015). Geographical and socioeconomic inequalities in women and children's nutritional status in Pakistan in 2011: an analysis of data from a nationally representative survey. The Lancet Global Health, 3(4), e229-e239.

FAO. (2013). The multiple dimensions of food security. Food and Agriculture Organization of the United Nations. http://www.fao.org/

FAO. (2009). The state of Food Insecurity in the World. Economic crisis-impacts and lesson learned. Rome: Food and Agriculture Organization of the United Nations. http://www.fao.org/

FAO, IFAD and WFP. (2014). The State of Food Insecurity in the World 2014. Strengthening the enabling environment for food security and nutrition. Rome, FAO.

Frongillo, E. A., Nanama, S., (2006). Development and Validation of an Experience-Based Measure of Household Food Insecurity within and across Seasons in Northern Burkina Faso. J. Nutr. 136, 1409S-1419S. 
International Food Policy Research Institute. 2016. Global Nutrition Report 2016: From Promise to Impact: Ending Malnutrition by 2030. Washington, DC.

Kalugina, E., Radtchenko, N., Sofer, C. (2009). How do spouses share their full income? Identification of the sharing rule using self-reported income. Review of Income and Wealth, 55(2), 360-391.

Kingdon, G. G., Knight, J. (2006). Subjective well-being poverty vs. Income poverty and capabilities poverty? The Journal of Development Studies, 42(7), 1199-1224.

Klasen, S. (2008).Poverty, undernutrition, and child mortality: Some inter-regional puzzles and their implicationsfor research and policy. The Journal of Economic Inequality, 6(1), 89115.

Mies, M. (1982).The lace makers of Narsapur: Indian house wives produce for the world market. Zed Books.

National Nutrition Survey (2011). Planning and Development Division, Government of Pakistan

Nord, M., 2012. How much does the Supplemental Nutrition Assistance Program alleviate food insecurity? Evidence from recent programme leavers. Public Health Nutr. 15, 811-817. doi:10.1017/S1368980011002709

Masset, E. (2011). A review of hunger indices and methods to monitor country commitment to fighting hunger. Food policy, 36, S102-S108.

Ravallion, M., Lokshin, M. (2002).Self-rated economic welfare in Russia. European Economic Review, 46(8), 1453-1473.

Riffault H. (1991) How Poverty is Perceived. In: Reif K., Inglehart R. (eds) Eurobarometer. Palgrave Macmillan, London

Shams, K. (2014).Determinants of Subjective Well-Being and Poverty in Rural Pakistan: A Micro-Level Study.Social Indicators Research, 119(3), 1755-1773.

Smith, M.D., Kassa, W., Winters, P., (2017a). Assessing food insecurity in Latin America and the Caribbean using FAO’s Food Insecurity Experience Scale. Food Policy, 71, 48-61. doi:10.1016/j.foodpol.2017.07.005

Smith, M.D., Rabbitt, M.P., Coleman- Jensen, A., (2017b). Who are the World's Food Insecure? New Evidence from the Food and Agriculture Organization's Food Insecurity Experience Scale.World Dev. 93, 402-412. doi:10.1016/j.worlddev.2017.01.006 
Stevenson, B., and Wolfers, J. (2013). Subjective well-being and income: Is there any evidence of satiation? The American Economic Review, 103(3), 598-604.

Svedberg, P. (2002). Undernutrition overestimated. Economic Development and Cultural Change, 51(1), 5-36.

United Nations women calculations based on micro data from NIPS and ICF International, 2013. United Nations women calculations based on DHS (2012-13), 2013.

United Nations women calculations based on data from 2014-2015 FAO Food Insecurity Experience Scale (FIES) survey.

www.unwomen.org/en/what-we-do/economic-empowerment/facts-and-figures worldbank.org/mdgs/gender.html

Zhou, S., and Yu, X. (2017).Regional Heterogeneity of Life Satisfaction in Urban China: Evidence from Hierarchical Ordered Logit Analysis. Social Indicators Research, 132(1), $25-45$.

Webb, P., Coates, J., Frongillo, E.A., Rogers, B.L., Swindale, A., Bilinsky, P., (2006). Measuring Household Food Insecurity: Why It's So Important and Yet So Difficult to Do. J. Nutr. 136, 1404S-1408S. 


\section{Chapter 2 Do the Poor really Feel Poor? Comparing Objective Poverty with Subjective Poverty in Pakistan}

\subsection{Introduction}

The World Bank Development Report in 2013 indicates that 10.7 percent of the world's population lives on less than US $\$ 1.90$ per day, which is the current poverty line, set by the World Bank. ${ }^{6}$ Using the Pakistan Living Standard and Measurement (PSLM) 2014/15, the multidimensional poverty index based on the Alkire-Foster method, stands at 0.197, while the multidimensional poverty head count ratio was estimated at 38.8 percent of the population. Strong disparities in the poverty ratio between urban and rural areas also exist i.e. 9.4 percent in urban areas and 54.6 percent in rural areas. Consistently, the 2013 World Bank Development Report reveals that 29 percent of the people live below the poverty line in Pakistan. There is a hot debate over the measurement of poverty, as there are many different measures from different dimensions. Though the prevalent measurement applied in many countries exercises to set an objective poverty line, the comparison between different regions and groups is difficult (Deaton 2010). The objective poverty measures are prone to the changing pattern of purchasing power parity (PPP).

Uncertainty about PPP is not the only source of sensitivity in poverty measures. The national poverty lines are treated as precise cut-off. Likewise, poverty lines are set using standard technical rules, such as income, expenditure, or consumption, and not well informed in democratic discussion. For instance, there is an intensive discussion on the poverty line in India, which is set by the fixed calorie needs approach (Deaton \& Drèze 2009). The reason is that as if the economic condition of household improves, individuals will do less energy consumption work, which however would increase poverty based on the fixed calorie needs, even though this might not be the case. At the same time, small changes in the threshold can have large effects on the count when there is a large fraction of the population near the line. Thus, it is hard to justify

\footnotetext{
${ }^{6}$ Objective poverty is defined as 'when the household income or consumption, after adjusting for household composition, is below a designated threshold line. While subjective poverty is defined as 'an individual or households perception of their economics position in life (both broader and narrow concept of subjective poverty).
} 
treating people so differently, whether or not they happen to fall on one or the other side of a largely arbitrary line (Deaton \& Heston 2010).

Conventional poverty counts can also be very sensitive to survey design. For example, data availability issues on consumption instead of income, non-availability of regular annual surveys data and changes of surveys over time are some of the issues with the conventional measure of poverty. Again, loopholes exist about the ability of the household surveys to capture income and consumption accurately (Jodha 1988). Another example comes from Indian national sample survey carried out in 1998: seven-day recall for food and some other items in place of the 30-day period that had been their long standard. This change resulted in a sharp increase in the reported monthly expenditure, removing almost 175 million Indian from the national poverty count. The effect would have been larger if the standard nutritional approach was used (Deaton 2001). Hence, the global poverty estimates are a rough estimate, expecting classification errors. Keeping in view the above measurement, two methods gained prominence recently: one is the capability approach (Sen 1988, 1993) and the other one is the multidimensional approach.

Poverty is also a subjective feeling. Some who are not objectively poor may feel poor, while some who are objectively poor do not feel poor. In order to overcome the aforementioned problems, different from the mainstream literature, Van Praag (1968), and Vos and Garner (1991) suggest a concept of subjective poverty measure: turning self-reports of income adequacy into poverty lines.

Specifically, in contrast to conventional measures of objective poverty, different concepts of subjective poverty measures have been proposed by researchers ranging from Income Evaluation Question (IEQ), Minimum Income Question (MIQ), and consumption adequacy questions, to broader definition of subjective welfare such as asking questions about life satisfaction and happiness to a somewhat narrow yet comprehensive definition by ranking individuals on a ladder from the poorest to the richest. Among all, Van Praag (1968, 1971), first used an Income Evaluation Question (IEQ) for a household survey: what income is considered very bad, bad, not good, not bad, good, and very good. Likewise, Goedhart et al. (1977) asked households a Minimum Income Question (MIQ), what minimum income is needed 'to make ends meet'? The concept of income as a measure of poverty is likely to be misunderstood by respondents particularly in poor parts of the world. The critique about the income criterion comes from Garner and Vos (1995). Further, subjective poverty line is derived using qualitative questions 
about perceived food consumption adequacy (Pradhan and Ravallion 2000). Van Praag et al. (2003) find out the limitations of aforementioned procedure that income is only one predictor among other important demographic and socio-economic variables effecting subjective wellbeing. ${ }^{7}$

Instead of asking question about income metrics, Cantril (1995) resort to ask open-ended question from individuals usually called the Cantril ladder: where people place themselves on a ladder according to their happiness and life satisfaction. Stevenson and Wolfers (2013) tested the subjective well-being and income relationship using the five waves of the Gallup World Poll and World Values Survey, and ask questions about people's life satisfaction and happiness. Furthermore, Kingdon and Knight (2006), and Zhou and Yu (2017) use the life satisfaction question ranging from very dissatisfied (coded as 1) to very satisfied (coded as 5). Similarly, Deeming (2013) used four global measures of subjective well-being: life satisfaction, worthwhile, happy, and anxious ranging from the lowest to the highest ladder. Shams (2014) tested determinants of subjective well-being using a happiness index in Pakistan but limited to the rural domain. However, the broad definition is sometimes criticized on the ground that just because someone is poor does not mean he or she is unhappy or unsatisfied.

A narrow yet accurate and comprehensible approach to well-being is to define the Cantril (1965) ladder from the poorest to the richest. There have been a number of studies. For instance, Mangahas (1995) for Philippines, ask people whether they are poor, borderline, or non-poor. Likewise, Riffault (1991), ask a similar question consisting seven-step ladders from the poorest to the richest, and the Euro barometer identifies the poor who fall on the lowest two ladders. Ravallion and Lokshin (2002) conducted a similar study asking people's perception of their economic welfare in Russia. The question goes as "please imagine a 9-step ladder where on the bottom, the first step, stand the poorest people, and on the highest step, the ninth, stand the rich. On which step are you today?"

Keeping the aforementioned literatures in view, we study the subjective poverty in Pakistan by asking the following question from the household head: "In our society some people have higher economic position (the rich), and other has lower economic position (the poor). Below is a scale from one to ten. The numbers 1 through 10 represent different levels of economic position, from

\footnotetext{
${ }^{7}$ Subjective well-being is defined as “a person's cognitive and affective evaluations of his or her life' (Diener et al. 2002). We have broader concept of subjective poverty (life satisfaction, happiness) and narrow definition of subjective poverty (perception about economic situation). In this study, we use the narrow definition of subjective poverty.
} 
the lowest to the highest. On the scale, please indicate the position you occupy". Following Riffault (1991), we also constructed a binary variable of extreme poor consisting of the lowest two ladders and non-poor consisting of 3 to 10 ladders. Our intension is to value the individual freedom by asking individuals directly about his/her economic situation, instead of asking about life satisfaction, happiness, or income metrics. Because sometimes, satisfaction and happiness have different interpretations/connotations for individuals surveyed, despite their economic status. $^{8}$

The benefit of this narrowed definition is that it makes the comparison to a monetary poverty line more meaningful. Another advantage of this perception type variable, unlike orthodox and/or physical variables, is that it does not require extensive cleaning of the data and is therefore less expensive. Generally, the perception type survey items are easy to answers. Unlike the official poverty line, the subjective poverty threshold is not easy to manipulate. The subjective poverty nevertheless also confronts some issues such as response errors, random discrepancies in the interpretation of the survey question, idiosyncratic differences in the respondents' moods and differences in preferences (taste and personality). However, for specific purposes such as welfare impacts of policies and overall well-being, one would not attach much significance to such differences.

Self-rated questions about well-being are established as an alternative to a poverty measure. Nonetheless, to the best of our knowledge, research on subjective poverty is carried out in a limited way in Pakistan, although Pakistan is a large country with a population close to 200 million. In recently years, Pakistan has experienced a relatively rapid economic growth. Hence, the motivation is to fill the gap in the research area of subjective poverty in Pakistan. The prime objective of the study is to compare the subjective and objective poverty line for Pakistan. The study also attempts to yield anti-poverty policy implications by incorporating the subjective poverty measure into the conventional approaches.

The rest of the paper is organized as follows. Section 2 explains the data design, variables and shows descriptive statistics of the study; Section 3 presents the empirical method, followed by empirical results and discussions in section 4. Finally, section 5 concludes and gives some policy recommendations.

\footnotetext{
${ }^{8}$ Individual freedom means the right to express their opinions and communicate freely with others their economic position without any constraints.
} 


\subsection{Data}

\subsubsection{Research design}

Our analysis is based on the third round Pakistan Panel Household Survey (PPHS) in 2010, a joint project of the Pakistan Institute of Development Economics (PIDE) and the World Bank. The sample size is 4142 households covering four provinces of which 2800 are rural and 1342 urban households. ${ }^{9}$ After cleaning the data with missing variables, we obtained 3015 households consisting of 2143 rural and 872 urban samples. The PPHS covers a wide range of issues, including fertility, education, employment, poverty, health, nutrition, food insecurity, housing, and well-being. The current study utilizes cross sectional data. The cross sectional survey data is easier and cheaper than the longitudinal data, no follow up is required, and possesses greater control over precision of estimates in subgroups particularly due to stratified sampling. The disadvantage of using survey data are no control over purpose and method of data collection in case of secondary data. In addition, we cannot say much about causality but only correlation.

\subsubsection{Variables}

The basic subjective poverty question is asked from the head of the household, i.e. rank the household from the lowest ladder 1 (poor) to the highest ladder 10 (rich) in terms of economic position. We have also constructed a binary variable of subjective poverty which consists of the samples of the lowest 2 ladder as the poor and the rest as non-poor (Riffault 1991). For the purpose of comparison, we have categorized objective poverty based on per capita consumption of $\$ 1.25$ and $\$ 1$ per day.

The important determinants of subjective poverty included in the analysis are: (1) Per capita consumption which is the main measure of objective poverty; (2) Household composition, which is considered differently in subjective and objective poverty; (3) Gender based classification of children less than 18 years and also less than 6 years; (4) Age, education, marital status and employment status of the household head; moreover, (5) Main household characteristics which are expected to affect subjective poverty, i.e. household asset proxies by television, agriculture land holding, water and sanitation facilities, borrowing and livestock.

\footnotetext{
${ }^{9}$ Districts included in the sample from four provinces are; Dir, Mardan and Lakki Marwat from KP; Attock, Hafizabad, Faisalabad, Vehari, Bahawalpur and Muzaffargarh from Punjab; Larkana, Nawabshah, Mirpur Khas, and Badin from Sindh; and Loralai, Khuzdar, and Gwadar from Baluchistan.
} 
In addition, food insecurity and physical insecurity are of high value to poor people, but they are often missing due to difficult measurement (Sen 1988). Alkire (2007) stressed that insufficient empirical data which has a direct impact on the human development and well-being, particularly on the poor, such as physical security, agency, and empowerment, could improve standard surveys in a promising way. To analyze whether their inclusion adds sufficient influence to poverty and policy relevance, we take into account physical security measured by community insecurity and food insecurity in the analysis. The community insecurity question asked from the household head "in the last twelve months, have you heard incidents or injury or property damage experienced by others living in your community?" The community security question can have strong impact on well-being and policy relevance, because when the data was collected in 2010, terrorism was at its peak in Pakistan. Similarly, the other important determinant included in the study is, "During the last 12 months was your household worried any time that your food would run out before you had money to buy more?" Clearly, the food insecurity question also has strong impact on the well-being, due to a bad harvest in 2010, which almost destroyed fifty percent of the harvest. Moreover, to control for regional heterogeneities (such as religion, social differences), regional and provincial dummies are incorporated in the analysis.

Two interaction terms are included, which are considered necessary for the analysis: the interaction between household being farmers and having agriculture land. We expect a positive effect of the interaction because agriculture land owning and farmer has strong consequences on poverty. Likewise, the interaction between household asset and per capita consumption has also an impact on subjective poverty. Because having television in the house does not alone manifest well-being, the interaction with the income or consumption makes strong assumption of being well off. Hence, we expect a significant effect of the interactions on the subjective well-being. Table 2.1 presents the definition and description of variables included in the analysis.

\section{Table 2.1 Definition of variables}

\begin{tabular}{ll}
\hline Variables & Definitions \\
\hline $\begin{array}{l}\text { Outcome variables } \\
\text { Subjective poverty, }(1-\end{array}$ & $\begin{array}{l}\text { In our society some people have high economic position (the rich), and } \\
\text { other have low economic position (the poor). Below is a scale from one to } \\
\text { ten. The numbers } 1 \text { through } 10 \text { represent different levels in terms of } \\
\text { economic position, from the lowest to the highest. On the scale, please } \\
\text { indicate the position you occupy. } \\
\text { We define the scale of 1-2 as poor, and the rest as non-poor }\end{array}$
\end{tabular}




\begin{tabular}{|c|c|}
\hline Variables & Definitions \\
\hline & Poor $=0$, Non-poor $=1$ \\
\hline \$1perdaypovertyline & Below $\$ 1$ per day is poor, above non-poor (per capita consumption) \\
\hline $\begin{array}{l}\$ 1.25 \text { per daypoverty } \\
\text { line }\end{array}$ & $\begin{array}{l}\text { Below } \$ 1.25 \text { per day per person is poor and above non-poor (per capita } \\
\text { consumption) }\end{array}$ \\
\hline $\begin{array}{l}1.90 \$ \text { per day poverty } \\
\text { line }\end{array}$ & Below $\$ 1.9$ per day is poor, above non-poor (per capita consumption) \\
\hline $\begin{array}{l}\text { Comparison } \quad \text { (Four } \\
\text { categories) }\end{array}$ & $\begin{array}{l}\text { Category } 1=\text { overall non-poor (both subjective and objective non-poor), } \\
\text { category } 2=\text { objective poor and subjective non-poor category } 3=\text { subjective } \\
\text { poor and objective non-poor category } 4=\text { overall poor (both subjective and } \\
\text { objective poor) }\end{array}$ \\
\hline Explanatory variables & \\
\hline $\begin{array}{l}\text { Log of per capita } \\
\text { consumption }\end{array}$ & $\begin{array}{l}\text { Household natural log of per capita consumption used as proxy for } \\
\text { household per capita income per month. }\end{array}$ \\
\hline Household size & Total member of the household as a continuous variable \\
\hline $\begin{array}{l}\text { Gender based } \\
\text { classification of children } \\
\text { less than } 18 \text { years \& } 6 \\
\text { years age }\end{array}$ & $\begin{array}{l}\text { We have constructed continuous variables of children male and female } \\
\text { separately as an explanatory variable. To examine how the gender of child } \\
\text { affects well-being poverty }\end{array}$ \\
\hline Household head age & Included both age and age-squared \\
\hline $\begin{array}{l}\text { Household head } \\
\text { education }\end{array}$ & We have used education as years of schooling as continuous variable. \\
\hline $\begin{array}{l}\text { Household Head marital } \\
\text { status }\end{array}$ & $\begin{array}{l}\text { We divide marital status of household head into three groups. Group- } 1 \\
\text { married. Group- } 2 \text { is equal to divorced. Group- } 3 \text { is equal to single. }\end{array}$ \\
\hline $\begin{array}{l}\text { Household head } \\
\text { employmentlevel }\end{array}$ & $\begin{array}{l}\text { We categorize employment status of the household head into whether } \\
\text { household head is employed, farmer or run his own business. } \\
\text { Yes }=1, \text { No }=0\end{array}$ \\
\hline Agriculture land & $\begin{array}{l}\text { Did the father of the head of household own agriculture land? Yes }=1, \text { No }= \\
0\end{array}$ \\
\hline livestock & $\begin{array}{l}\text { Does your household currently own animals? } \\
\text { Yes }=1, \text { No }=0\end{array}$ \\
\hline Household's borrowing & $\begin{array}{l}\text { Have you ever tried to borrow in the past } 12 \text { months and has been } \\
\text { successful? } \\
\text { Yes }=1, \mathrm{No}=0\end{array}$ \\
\hline Food insecurity & $\begin{array}{l}\text { During the last } 12 \text { months was your household worried any time that your } \\
\text { food would run out before you had money to buy more? } \\
\text { Yes }=1, \mathrm{No}=0\end{array}$ \\
\hline $\begin{array}{l}\text { Community insecurity } \\
\text { level }\end{array}$ & $\begin{array}{l}\text { In the last } 12 \text { months, have you heard any incidents or injury or property } \\
\text { damage experienced by others living in your community? Yes }=1 \text {, No }=0\end{array}$ \\
\hline $\begin{array}{l}\text { Agriculture landfarmer } \\
\text { interaction }\end{array}$ & We use interaction term for farmers having own agriculture land \\
\hline Water facility & $\begin{array}{l}\text { World health organization definition of improved drinking water definition } \\
\text { Improved }=1 \text {, No }=0\end{array}$ \\
\hline Sanitation facility & $\begin{array}{l}\text { WHO definition of improved sanitation facility } \\
\text { Improved }=1, \text { No }=0\end{array}$ \\
\hline Residence own & $\begin{array}{l}\text { Whether household has its own house? } \\
\text { Yes }=1, \text { No }=0\end{array}$ \\
\hline $\begin{array}{l}\text { Household } \\
\text { (television) }\end{array}$ & $\begin{array}{l}\text { Household having television in their houses as an asset } \\
\text { Yes }=1, \text { No }=0\end{array}$ \\
\hline $\begin{array}{l}\text { Interaction term per } \\
\text { capita consumption plus }\end{array}$ & We use interaction between asset and consumption \\
\hline
\end{tabular}




\begin{tabular}{ll}
\hline Variables & Definitions \\
\hline asset & We have two region, Urban $=1$, Rural $=0$ \\
Region & Province- $1=$ Punjab, province- $2=$ Sindh, province- $3=$ KP, province- $4=$ \\
Provinces & Baluchistan \\
\hline
\end{tabular}

\subsubsection{Descriptive statistics}

Table 2.2 shows descriptive statistics of demographic and socio-economic characteristics of the households under study. Almost fifty percent of the household heads are illiterate. Average age of the household head is 48. Equivalent household size is calculated according to the modified OECD equivalence scale. The average household size is 5.38 which is slightly less than the average household size 6.41 (Household Integrated Economic Survey, 2011-12) and national average household size 6.38 members observed for the period 2010-11. Similarly, 31 percent of the households have agriculture land holding, only 11 percent livestock holding, and approximately 10 percent run their own businesses. In addition, 78 percent of the households have their own residence, 50 percent possess assets, three-fourths percent have no access to borrowing, and approximately half of the households have no sanitation facility. Alarmingly, 59 percent of the households are food insecure and 21 percent faced physical insecurity. Almost 70 percent of the households reside in rural area. Moreover, the distributions of households are 30, 31, 11, and 18 percent for Punjab, Sindh, KP and Baluchistan, respectively.

Table 2.2 Demographic and socio-economic characteristics of households

\begin{tabular}{|c|c|c|c|c|}
\hline Characteristics & Mean & SD & Min & Max \\
\hline \multicolumn{5}{|l|}{ Outcome variables } \\
\hline Subjective poverty $(1-10)$ & 3.34 & 1.45 & 1 & 10 \\
\hline $\begin{array}{l}\text { Subjective poverty } \quad \text { (Poor- } \\
\text { nonpoor) }\end{array}$ & 0.72 & 0.45 & $0=$ Poor & $1=$ Non-poor \\
\hline Objective poor ( $\$ 1$ per day) & 0.68 & 0.47 & $0=$ Poor & $1=$ Non-poor \\
\hline Objective poor ( $\$ 1.25$ per day) & 0.52 & 0.50 & $0=$ Poor & $1=$ Non-poor \\
\hline Objective poor ( $\$ 1.9$ per day) & 0.24 & 0.42 & $0=$ Poor & $1=$ Non-poor \\
\hline \multicolumn{5}{|l|}{ Household head characteristics } \\
\hline Age & 47.87 & 14.84 & 16 & 90 \\
\hline Schooling & 3.81 & 4.69 & 0 & 16 \\
\hline Employed & 0.83 & 0.37 & $0=\mathrm{No}$ & $1=$ Yes \\
\hline Own Business & 0.10 & 0.30 & $0=\mathrm{No}$ & $1=$ Yes \\
\hline Farmer & 0.31 & 0.46 & $0=\mathrm{No}$ & $1=$ Yes \\
\hline \multicolumn{5}{|l|}{ Household characteristics } \\
\hline Log per capita consumption & 7.76 & 0.64 & 4.98 & 11.56 \\
\hline Household size & 5.38 & 2.80 & 2 & 26 \\
\hline Girls $<18$ years & 1.64 & 1.55 & 0 & 14 \\
\hline
\end{tabular}




\begin{tabular}{lllll}
\hline Characteristics & Mean & SD & Min & Max \\
\hline Boys < 18 years & 1.76 & 1.64 & 0 & 16 \\
Boys < 6 years & 0.56 & 0.87 & 0 & 5 \\
Girls < 6 years & 0.55 & 0.85 & 0 & 5 \\
Agriculture land holding & 0.39 & 0.48 & $0=$ No & $1=$ Yes \\
Household livstock & 0.11 & 0.31 & $0=$ No & $1=$ Yes \\
Household borrowing & 0.26 & 0.44 & $0=$ No & $1=$ Yes \\
Household asset (TV) & 0.50 & 0.50 & $0=$ No & $1=$ Yes \\
Own residence & 0.78 & 0.41 & $0=$ No & $1=$ Yes \\
Food insecurity & 0.59 & 0.49 & $0=$ No & $1=$ Yes \\
Physical injury & 0.21 & 0.41 & $0=$ No & $1=$ Yes \\
Water facility & 0.91 & 0.27 & $0=$ No & $1=$ Yes \\
Sanitation facility & 0.54 & 0.49 & $0=$ No & $1=$ Yes \\
Province & 2.09 & 1.02 & 1 & 4 \\
Region & 0.28 & 0.45 & $0=$ rural & $1=$ urban \\
\hline
\end{tabular}

Note: Definition of variables are given in Table 1. Author's calculation

Table 2.3 shows descriptive statistic of subjective poverty in Pakistan. The first part is the original question asked the household head about his subjective poverty which consists of 10 ladders. The result shows that almost 60 percent of household subjective poverty falls on the first three ladders. This indicates that significant majority of the household are subjectively poor. The second part of the Table shows the poor and non-poor category. The poor category consists of the lowest two ladders and non-poor as the rest rank from 3 to 10. This classification shows that 28 percent of the household are poor subjectively at the national level (Table 2.2). The regional and Punjab subjective poverty statistics are in line with national subjective poverty trend. While, the distribution of subjective poverty based on this ranking shows stark divergence for other provinces. That is, based on the first two ladders, 2.59 percent of households of Baluchistan, 12.69 percent of KP and 44.71 percent of Sindh province are poor.

Table 2.3 also shows the national average subjective poverty as well as regional and provincial subjective poverty. This is calculated as 10 minus the average rank to the 10 step subjective wellbeing question. The overall national subjective poverty is 7.65 , which indicates that most of the people still regard themselves poor. The regional distribution of subjective poverty for urban and rural areas is 7.76 and 7.61 respectively. Interestingly, urban people subjectively feel poorer than rural, though the difference is not large and significant. Moreover, the distribution of average subjective poverty across four provinces of Pakistan is 7.84, 8.00, 6.80, and 7.24 for Punjab, Sindh, Khyber Pakhtunkhwa (KP) and Baluchistan, respectively. This depicts that Sindh ranks highest in subjective poverty, whereas KP is the least poor in the national ranking of subjective 
poverty. This might have resulted from regional heterogeneities, such as, religion, regional income inequality, and physical security. Similarly, the districts sampled, from Punjab are poorer in comparison with other districts in the same province. In addition, districts chosen from Baluchistan are better off compared to other districts in the same province. This indicates that districts chosen from Sindh and Punjab are poorer in relative terms.

Table 2.3 Descriptive Statistics of Subjective Poverty in Pakistan

\begin{tabular}{|c|c|c|c|c|c|c|c|c|c|c|}
\hline \multicolumn{11}{|c|}{ Part-1: Original question rank from poorest to the richest (\%) } \\
\hline Category & Poorest & 2 & 3 & 4 & 5 & 6 & 7 & 8 & 9 & Richest \\
\hline National & 9.25 & 19.47 & 30.68 & 19.37 & 14.26 & 4.21 & 1.96 & 0.66 & 0.07 & 0.07 \\
\hline Urban & 9.86 & 19.27 & 33.37 & 18.92 & 14.11 & 2.64 & 1.61 & 0.11 & 0.00 & 0.11 \\
\hline Rural & 9.01 & 19.55 & 29.58 & 19.55 & 14.33 & 4.85 & 2.10 & 0.89 & 0.09 & 0.05 \\
\hline Punjab & 8.65 & 21.09 & 38.58 & 15.35 & 11.86 & 3.11 & 1.17 & 0.19 & 0.00 & 0.00 \\
\hline Sindh & 15.97 & 28.74 & 24.18 & 14.14 & 9.67 & 3.56 & 2.37 & 1.28 & 0.09 & 0.00 \\
\hline $\mathrm{KP}$ & 2.37 & 10.32 & 17.85 & 21.72 & 33.33 & 10.97 & 3.23 & 0.22 & 0.00 & 0.00 \\
\hline Baluch. & 0.94 & 1.66 & 42.35 & 40.00 & 11.06 & 1.18 & 1.42 & 0.71 & 0.24 & 0.47 \\
\hline \multicolumn{11}{|c|}{ Part-2: Poor verses non-poor $(\%)$} \\
\hline Category & Poor & \multicolumn{9}{|c|}{ Non-poor } \\
\hline National & 28.72 & \multicolumn{9}{|c|}{71.28} \\
\hline Urban & 29.13 & \multicolumn{9}{|c|}{70.87} \\
\hline Rural & 28.56 & \multicolumn{9}{|c|}{71.44} \\
\hline Punjab & 29.74 & \multicolumn{9}{|c|}{70.26} \\
\hline Sindh & 44.71 & \multicolumn{9}{|c|}{55.29} \\
\hline $\mathrm{KP}$ & 12.69 & \multicolumn{9}{|c|}{87.31} \\
\hline Baluch. & 2.59 & \multicolumn{9}{|c|}{97.41} \\
\hline
\end{tabular}

Part-3: Average subjective poverty in different regions and provinces of Pakistan

\begin{tabular}{llllllll}
\hline Sample & National & Urban & Rural & Punjab & Sindh & KP & Baluch. \\
\hline Poverty & 7.65 & 7.76 & 7.61 & 7.84 & 8.00 & 6.80 & 7.24 \\
\hline
\end{tabular}

N = 3015 Source: PPHS 2010, Note: To calculate the average subjective poverty we rank original question in descending order. Baluch. stands for Baluchistan

Table 2.4 depicts the results of the objective poverty count together with the poverty gap index. The overall poverty headcount index is $32 \%$ and $48 \%$ using $\$ 1$ per day and $\$ 1.25$ per day, respectively. Though the new poverty line set by the World Bank is $\$ 1.90$ per day. It is too high for Pakistan, where almost $76 \%$ are poor based on $\$ 1.90$ per day; hence, it is not reasonable and relevant to this study. We therefore use $\$ 1$ and $\$ 1.25$ per day as the poverty lines for this study. Our results are almost in line with the national poverty line (Rs. 1745), which was about $36 \%$ 
during the analysis period $2010 .{ }^{10}$ However, the rural poverty is higher compared to the urban poverty. Consequently, we find contrast findings of subjective and objective poverty for urban and rural domains. The two most poverty ridden provinces Baluchistan and Khyber Pakhtunkhwa (KP) are less poor compared to Punjab province in our analysis. The poverty gap index, which is defined as the average ratio of the poverty gap to the poverty line and squared poverty gap index have the same conclusion as the headcount index.

Table 2.4 Aggregate poverty measures $1 \$, \$ 1.25$ and \$1.9 per person per day (objective poverty)

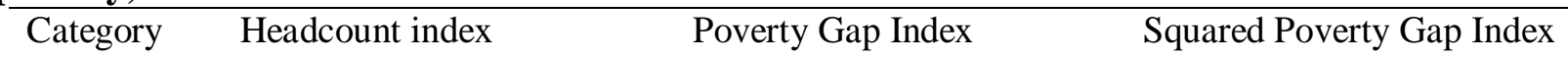

\begin{tabular}{llllllllll} 
& \multicolumn{1}{c}{$\$ 1$} & $\$ 1.25$ & $\$ 1.9$ & $\$ 1$ & $\$ 1.25$ & $\$ 1.9$ & $\$ 1$ & $\$ 1.25$ & $\$ 1.9$ \\
\hline $\begin{array}{l}\text { Overall } \\
\text { Region }\end{array}$ & 0.32 & 0.48 & 0.76 & 0.08 & 0.14 & 0.32 & 0.03 & 0.06 & 0.16 \\
Urban & 0.21 & 0.37 & 0.70 & 0.05 & 0.09 & 0.25 & 0.01 & 0.03 & 0.12 \\
$\begin{array}{l}\text { Rural } \\
\text { Province }\end{array}$ & 0.36 & 0.52 & 0.79 & 0.09 & 0.16 & 0.34 & 0.04 & 0.07 & 0.18 \\
Punjab & 0.31 & 0.46 & 0.73 & 0.08 & 0.14 & 0.31 & 0.03 & 0.06 & 0.16 \\
Sindh & 0.40 & 0.56 & 0.83 & 0.11 & 0.18 & 0.27 & 0.04 & 0.08 & 0.20 \\
KP & 0.29 & 0.45 & 0.74 & 0.06 & 0.13 & 0.30 & 0.02 & 0.05 & 0.14 \\
Baluchistan & 0.18 & 0.33 & 0.68 & 0.03 & 0.07 & 0.23 & 0.008 & 0.02 & 0.10 \\
\hline
\end{tabular}

Author'scalculation PPHS-2010

Furthermore, appendix Table 2.9 delineates the sampling weight for the overall sample as well as urban-rural domains. The population for each district is taken from the census 1998. The estimation is done with the sampling weight after cleaning the data. The last three columns from left to right represent the normalized sampling weight of overall, urban, and rural sample respectively.

\subsection{Empirical Model}

To analyze the determinants of subjective poverty which individuals ranked from the poorest to the richest and objective poverty captured by per capita consumption, we use an ordered probit

\footnotetext{
${ }^{10}$ The national poverty line is Rs. 1,745 per capita per month(2010/11). The official poverty line was estimated using the Food Energy Intake (FEI) method, which regresses household consumption expenditure on calories consumed. The poverty line is evaluated at the minimum threshold caloric intake requirement (Economic Survey 2013-14).
} 
model, while a probit model is used as robustness check (Greene 2011). ${ }^{11}$ In order to compare subjective poverty with objective poverty, we utilize a multinomial probit model and Spearman's rank correlation test.

The latent outcome variable denoted by $s p_{i}^{*}$ ranging from $-\infty$ to $+\infty$ is assumed to be a linear function of independent explanatory variables as:

$$
s p_{i}^{*}=\beta^{i} x_{i}+\epsilon_{i}
$$

Where $\mathrm{i}$ is the individual observation, $\epsilon_{i}$ is the corresponding error with standard normal distribution. We use ten-scale (ladder) latent response variable ranging from the lowest 'poor' to the highest 'rich'. The observed categorical variable $s p_{i}$ is related to unobserved $s p_{i}^{*}$ by the threshold model define as;

$$
s p_{i}=\left\{\begin{array}{ccc}
1 & \text { if }-\infty<s p_{i}^{*} \leq \tau_{1} \\
2 & \text { if } & \tau_{1}<s p_{i}^{*} \leq \tau_{2} \\
& & \cdot \\
10 & \text { if } & \tau_{9}<s p_{i}^{*} \leq+\infty
\end{array}\right.
$$

Where, $\tau_{1}$ to $\tau_{9}$ are the threshold (cut-off) points. Given the independent variables, the probability of being observed response variable corresponds to the probability that the latent response variable lies between the corresponding thresholds.

$\operatorname{Pr}(s p=1 \mid \mathrm{X})=\operatorname{Pr}\left(s p_{i}^{*} \leq \tau_{1}\right)=\Pi_{1}$

$\operatorname{Pr}(s p=2 \mid \mathrm{X})=\operatorname{Pr}\left(\tau_{1}<s p_{i}^{*} \leq \tau_{2}\right)=\Pi_{2}-\Pi_{1}$

$\operatorname{Pr}(s p=9 \mid \mathrm{X})=\operatorname{Pr}\left(\tau_{8}<s p_{i}^{*} \leq \tau_{9}\right)=\Pi_{9}-\Pi_{8}$

$\operatorname{Pr}(s p=10 \mid \mathrm{X})=\operatorname{Pr}\left(\tau_{9}<s p_{i}^{*}\right)=1-\Pi_{9}$

Where $\Pi_{s}$ is the probability distribution function. Where, "sp" stands for subjective poverty.

Similarly, the probit models for both subjective poverty and objective poverty: "poor", "nonpoor" are given by:

$\operatorname{Pr}(s p)=0 \mid \mathrm{X})=\operatorname{Pr}\left(s p_{i}^{*} \leq \tau\right)=\Pi$

$\operatorname{Pr}(s p)=1 \mid \mathrm{X})=\operatorname{Pr}\left(s p_{i}^{*}>\tau\right)=1-\Pi$

\footnotetext{
${ }^{11}$ we utilize ordered probit model and probit model in our analysis given the nature of the data set. Using the ordered probit model sometime, the parallel regression assumption is violated. In this case, the generalized ordered probit is used as an alternative model. However, this model is very sensitive to low frequency counts. As a result, we have chosen to present the results of ordered probit model. In addition, we use the multinomial model, which is usually used when the parallel regression assumption is violated.
} 
Where $\tau$ is the threshold value, below the threshold value lie the poor and above the threshold value lie the non-poor.

Table 1 elaborates the explanatory variables included in our model, and provides information about household demographic characteristics, household socio-economic characteristics, household food insecurity situation, community insecurity situation, and regional and province dummies to control for regional heterogeneities. The econometric model is specified as:

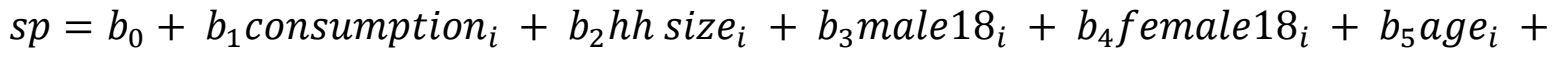

$$
\begin{aligned}
& b_{6}(\text { age })_{i}^{2}+b_{7} e d u c_{i}+b_{8} \text { marital stautus }_{i}+b_{9} \text { business }_{i}+b_{10} \text { agriculture land }_{i}+ \\
& b_{11} \text { farmer }_{i}+b_{12} \text { agri.farmer }_{i}+b_{13} \text { borrowing }_{i}+b_{14} \text { livestock }_{i}+b_{15} \text { assetTV }_{i}+
\end{aligned}
$$

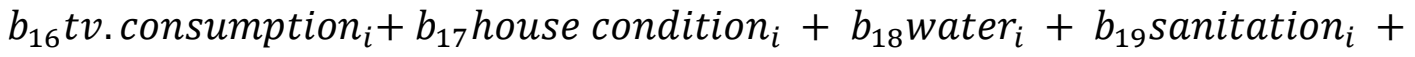

$$
\begin{aligned}
& b_{20} \text { food insecurity }_{i}+b_{21} \text { physical insecurity } i+b_{22} \text { region }_{i}+b_{23} \text { province }_{i}+e_{i}
\end{aligned}
$$

The above-mentioned explanatory variables are considered necessary determinants of subjective and objective poverty in the literature.

\subsubsection{Comparison between subjective poverty and objective poverty}

The multinomial probit model is a generalized form of the probit model used when outcome variable takes on several categories. The model attempts to explain the relative effect of different explanatory variables on the outcome variable categories. The choices/categories are called alternatives and are coded as $\mathrm{j}=1,23,4$. Our data consists of alternative-invariant or case specific regressor - the regressors vary over the individual but do not vary over the alternative $\mathrm{j}$. The probability that individual i select alternative $\mathrm{j}$ is given by:

$$
p_{i j}=p\left(y_{i}=j\right)=\theta\left(x_{i j}^{\prime} \beta\right)
$$

We utilize four alternatives of the outcome variable; subjective non-poor and objective non-poor as category 1 (overall non-poor). Category 2 constitutes of subjective non-poor and objective poor. Category 3 consists of subjective poor but objective non-poor. Finally, category 4 deals with subjective and objective poor households (overall poor). For this purpose, we utilized the binary subjective poverty (lowest two ranks as being subjectively poor and above rank two as non-poor) and objective poverty measured less than $\$ 1.25$ per day as poor (see appendix Table 2.10 for $\$ 1$ results).

In addition, as a robust check of comparison between the subjective and objective poverty, we resort to simple Spearman's rank correlation coefficient. There are two methods to calculate 
Spearman correlation: data without tied rank, and data with tied rank. Clearly, our data set includes tied rank; hence, we use the second method of Spearman's rank correlation coefficient method.

$$
\rho=1-\frac{6 \sum d_{i}^{2}}{n\left(n^{2}-1\right)} \rho=\frac{\sum_{i}\left(x_{i}-\bar{x}\right)\left(y_{i}-\bar{y}\right)}{\sqrt{\sum_{i}\left(x_{i}-\bar{x}\right)^{2} \sum_{i}\left(y_{i}-\bar{y}\right)^{2}}}
$$

The Spearman's rank order correlation is a non-parametric test that measures the strength and direction between two monotonic variables, taking values from +1 to -1 . The closer the value to zero, the weaker is the association between the ranks.

Now the question is that how to utilize the Spearman's correlation to compare the subjective with objective poverty. For this purpose, first we run the equation of subjective well-being ranging from the poorest to the richest rank (1-10). Then we determine the predicted value for the outcome (1). The outcome (1) is the predicted probability of being the poorest household. Afterward, we subtract the predicted probability of outcome (1) from 1 to get the probability of being non-poor. The Spearman's correlation test is utilized to test correlations between the new predicted probability and the per capita household consumption and between the original subjective question and per capita consumption. The null hypothesis states that the two variables are independent. If the null hypothesis were not rejected, it would mean that the subjective poverty is independent from the objective poverty level, implying both concepts should be taken into account while making and implementing poverty reduction strategies depending on the situation.

\subsection{Empirical Results and Discussions}

\subsubsection{Determinants of Subjective Poverty}

Table 2.5 presents the findings of the determinants of subjective poverty. The household income as well as consumption is an important determinant of subjective poverty. Actual per capita consumption and income turn out to be highly significant determinants of subjective well-being (Diener et al. 1993; Pradhan and Ravallion 2000; Ravallion and Lokshin 2002; Lever 2004; Kingdon and Knight 2006; Stevenson and Wolfers 2013; Deeming 2013). The current study confirms that household per capita consumption is an important determinant of subjective poverty (Diener and Biswas-Diener 2002; Zhou and Yu, 2017). The coefficient of per capita consumption is 0.25 indicating that as per capita consumption increases, the subjective poverty 
decreases significantly. Similarly, one unit increase in log of household per capita consumption leads to 11.7 percentage point lower probability of experiencing subjective poverty. However, there is a so-called Easterlin Paradox: Income is positively correlated with subjective well-being at the individual level, but not important at the aggregate/average level. Layard (2005) tested this paradox for United States and Western Europe, and finds that since 1945 the personal income doubled, but subjective well-being hardly increased or even negative sometimes. ${ }^{12}$ However, a recent study by Oishi and Kesebir (2015), states that Easterlin paradox can be explained partly by inequality. They examined the Easterlin Paradox for 34 countries, and confirmed that economic growth was not associated with increase in happiness when it was accompanied by growing income inequality. It suggests that equal distribution of national wealth is the prerequisite to eradicate subjective poverty.

Similarly, demographic variables play a pivotal role in determining subjective poverty. Specifically, household size is an important variable in determining the economic situation of the household particularity in developing countries due to high dependency ratio. As the household size increases, the chance of being in the poor bracket falls significantly. The coefficient of household size is 0.05 , and statistically significant. It means as the household size increases the well-being of the household improves significantly. This can be manifested from the average marginal effect, which indicates that an increase in household size is associated with 1.8 percentage point higher probability of being subjectively better off. Our findings are almost similar to the existing studies. The subjective poverty has a reasonable relationship to family size. Winkelmann (2005) reveals that subjective well-being improves if income and household size increases proportionally. This indicates that for additional members of households, income equivalent scale should give a weight lower than one.

We have also constructed gender-based groups: one is children age less than 18 years and other one is children age group less than 6 years based on gender classification. The motivation of this classification is to check the impact of the classification of children based on gender on the overall household well-being. The study confirms that with the same age group, male children are preferred over female children subjectively. For instance, an increase in the number of male

\footnotetext{
${ }^{12}$ We also check the linear relationship between the district average value of the ladder (subjective well-being) and the log of per capita consumption to check the Easterlin Hypothesis (1974), and found a linear relationship among the districts average value of the ladder (average subjective well-being) and log per capita consumption. Appendix Figure 2.1.
} 
children compared with female children under 6 years of age lead to 2.9 percentage point lower chance of experiencing poverty subjectively. However, the relative importance of being male child is higher for both age groups objectively. The reason could be due to gender bias, because households having more male children have less household size, so they are less poor in objective measure. Winkelmann (2005) examined that well-being of individuals within the same family is highly correlated. The correlation is higher among siblings compared to correlation among spouses.

Similarly, feelings of belonging and identity, stable and secure marital relationship have favorable effect on subjective poverty, and vice versa. Camfield et al. (2009), Dolan et al. (2008), Kingdon, and Knight (2006) indicate that probability of being unhappy increases with single households member compared to couples. Similarly, Ravallion and Lokshin (2002) analyzed that divorced or widowed individual put himself or herself on a lower ladder of subjective well-being. In this analysis, majority of the households head are married, so the result shows no significant differences for the households head being divorced or single. However, objectively the single person is worse off compared to married and divorced. As the household head becomes older, the subjective and objective poverty increases, however, insignificantly. Importantly, United Nations Development Program (UNDP) considers education as torchbearer for employment, revenue generation, creativity, self-respect and confidence. Education through many channels reduces subjective poverty: creating employment opportunities, accessing economic resources, sense of control over life, stable social relationship, especially marriage that increases social support (Ross and Van Willigen 1997). On the contrary, if job offer does not match with education level, it often results in frustration, hence negative impact on subjective well-being (ILO 2005). The correlation between education and subjective well-being is not linear, and often depends on how one defines, and uses the ideas of education, influences, and happiness (Michalos 2008). The current study finds a significant impact of education on subjective poverty. The coefficients of education are 0.02 and 0.05 for subjective poverty and objective poverty respectively and both are statistically significant. The findings indicate with each additional year of schooling the probability of well-being both subjectively and objectively increases. Similarly, the average marginal effect confirms that an additional year of schooling enhances 0.07 and 1.8 percentage point lower probability of experiencing subjective poverty and objective poverty respectively. 
Subjective well-being depends on how individuals have control over personnel, better application of one's capabilities, work objectives, security both physical and job, and social status of the work (Warr 1999). Happiness studies show complicated correlation between work and well-being. The current study also confirms that employment reduces subjective poverty, but it is statistically not significant. This study is consistent with previous studies such as that unemployment has a large negative impact on well-being (Winkelmann 2005). Moreover, the results indicate a significant positive impact on well-being of farmers having agriculture land. However, farmers without their own land have significant negative impact on well-being. It also shows that, in Pakistan being an agriculture country, in relative terms farmers are worse off compared to other occupations, perhaps because of the relationship of farmers and agriculture landowners such as crop sharing or land leasing which could make farmers pay one third of their output as rents.

Small farm size households perceive livestock holdings as a contributing factor in improving the quality of life. ${ }^{13}$ The findings confirm a negative but not significant impact of livestock on subjective poverty. This is due to the fact that majority of the cattle breeder live on subsistence livelihood. Interestingly, the household borrowing has a significant positive impact on subjective poverty. Majority of the households have no access to the formal means of borrowing. Therefore, in desperate situation they borrow with high cost from the informal sources, ultimately often unable to pay it back. Likewise, improved sanitation facility has also a significant effect on the eradication of subjective poverty, while the improved drinking water has no significant effect; perhaps because more than 90 percent of the households have access to clean drinking water. The finding also confirms the better the physical house type, the lesser the chances of household to fall in the subjective poverty.

Two important variables such as physical insecurity and food insecurity are utilized in the analysis, which have strong influence on human development and well-being (Alkire 2007). The coefficients of food insecurity and physical insecurity for subjective poverty are -0.28 and -0.16 respectively. The findings delineate that food vulnerable and physically insecure household are likely to fall in the subjective poverty, even when the household expenditure is controlled for. The reason could be due to a severe flood in 2010, which almost destroyed fifty percent of the

\footnotetext{
${ }^{13}$ WHO defines Quality of Life as an individual's perception of their position in life in the context of the culture and value systems in which they live and in relation to their goals, expectations, standards, and concerns. It is broader concept affected in a complex way by person's physical health, beliefs, psychology, social status, and relation to their environment.
} 
crops- backbone of the agriculture sector. Moreover, the terrorist activities were also active in the survey time. The interaction between household asset proxies by having television and household income has statistically significant negative impact on subjective poverty as well. In addition, television now almost become the necessary good, and has strong connection with income. Similarly, the present analysis confirmed that ownership of consumer durables raises subjective well-being (Ravallion and Lokshin 2002).

Finally, to control for regional heterogeneities, regional and provincial dummies are incorporated in the analysis. Importantly, contrary to the national poverty line, the household living in the rural areas, feels much better in terms of subjective poverty. Moreover, Mangahas (1995) find out that the subjective poverty is negatively related to urban areas. Hence, the current study is consistent with the previous studies. In addition, the KP province is the better off province compared to the remaining provinces, while Sindh province is the worst-off, which justify the results as the districts taken from the Sindh province is the least developed districts in the survey. The regional effect on subjective poverty can be due to perception of relative well-being, in that, living in affluent areas people feel relatively worse off (Ravallion and Lokshin 2002). This could better explain the large discrepancies in the subjective and objective poverty in the better off region.

Table 2.5 Subjective poverty determinants results

\begin{tabular}{|c|c|c|c|c|c|c|}
\hline \multirow[t]{2}{*}{ Variables } & \multirow{2}{*}{$\begin{array}{l}\text { Model }^{\mathrm{a}} \\
\text { Coefficient }\end{array}$} & \multirow{2}{*}{$\begin{array}{l}\text { Model } 2^{\mathrm{b}} \\
\text { Coefficient }\end{array}$} & \multirow{2}{*}{$\begin{array}{l}{\text { Model } 3^{\mathrm{c}}}^{\text {Coefficient }} \\
\end{array}$} & \multicolumn{3}{|c|}{ Model $4^{\mathrm{d}}$} \\
\hline & & & & Ave. $M E^{f}$ & Coefficient & Ave. ME \\
\hline \multicolumn{7}{|c|}{ Household size as a continuous variable } \\
\hline Household size & $\begin{array}{l}0.049 * * * \\
(0.011)\end{array}$ & $\begin{array}{l}0.049 * * * \\
(0.010)\end{array}$ & $\begin{array}{l}0.060 * * * \\
(0.017)\end{array}$ & $\begin{array}{l}0.018^{* * *} \\
(0.005)\end{array}$ & $\begin{array}{l}0.064 * * * \\
(0.016)\end{array}$ & $\begin{array}{l}0.019 \text { *** } \\
(0.004)\end{array}$ \\
\hline \multicolumn{7}{|l|}{ Gender classification } \\
\hline Girls $<18$ years & $\begin{array}{l}0.021 \\
(0.016)\end{array}$ & & $\begin{array}{l}0.030 \\
(0.024)\end{array}$ & $\begin{array}{l}0.009 \\
(0.007)\end{array}$ & & \\
\hline Boys $<18$ years & $\begin{array}{l}0.017 \\
(0.015)\end{array}$ & & $\begin{array}{l}0.038 \\
(0.025)\end{array}$ & $\begin{array}{l}0.011 \\
(0.007)\end{array}$ & & \\
\hline Girls $<6$ years & & $\begin{array}{l}0.052^{*} \\
(0.027)\end{array}$ & & & $\begin{array}{l}0.025 \\
(0.042)\end{array}$ & $\begin{array}{l}0.007 \\
(0.012)\end{array}$ \\
\hline Boys $<6$ years & & $\begin{array}{l}0.054 * * \\
(0.027)\end{array}$ & & & $\begin{array}{l}0.098 * * \\
(0.043)\end{array}$ & $\begin{array}{l}0.029 * * \\
(0.012)\end{array}$ \\
\hline Age of household head & & & & & & \\
\hline age & $\begin{array}{l}0.0006 \\
(0.010)\end{array}$ & $\begin{array}{l}0.005 \\
(0.010)\end{array}$ & $\begin{array}{l}-0.011 \\
(0.013)\end{array}$ & $\begin{array}{l}-0.003 \\
(0.003)\end{array}$ & $\begin{array}{l}-0.005 \\
(0.012)\end{array}$ & $\begin{array}{l}-0.001 \\
(0.003)\end{array}$ \\
\hline Age aquared & $\begin{array}{l}4.61 \mathrm{e}-06 \\
(0.0001)\end{array}$ & $\begin{array}{l}-3.34 \mathrm{e}-05 \\
(0.0001)\end{array}$ & $\begin{array}{l}0.0001 \\
(0.0001)\end{array}$ & $\begin{array}{l}0.000 \\
(0.000)\end{array}$ & $\begin{array}{l}5.31 \mathrm{e}-05 \\
(0.0001)\end{array}$ & $\begin{array}{l}0.000 \\
(0.000)\end{array}$ \\
\hline
\end{tabular}

Household head education (years of schooling as a continuous variable) 


\begin{tabular}{|c|c|c|c|c|c|c|}
\hline \multirow[t]{2}{*}{ Variables } & Model $1^{\mathrm{a}}$ & Model $2^{b}$ & Model $3^{\mathrm{c}}$ & & Model $4^{\mathrm{d}}$ & \\
\hline & Coefficient & Coefficient & Coefficient & Ave. $\mathrm{ME}^{\mathrm{f}}$ & Coefficient & Ave. ME \\
\hline \multirow[t]{2}{*}{ Schooling } & $0.026 * * *$ & $0.026 * * *$ & $0.024 * * *$ & $0.007 * * *$ & $0.024 * * *$ & $0.007 * * *$ \\
\hline & $(0.005)$ & $(0.005)$ & $(0.007)$ & $(0.002)$ & $(0.008)$ & $(0.002)$ \\
\hline \multicolumn{7}{|c|}{ Marital status (Reference category married) } \\
\hline \multirow[t]{2}{*}{ Divorced } & -0.062 & -0.067 & -0.066 & -0.019 & -0.073 & -0.022 \\
\hline & (0.099) & (0.099) & $(0.140)$ & $(0.042)$ & $(0.140)$ & $(0.042)$ \\
\hline \multirow[t]{2}{*}{ Single } & 0.048 & 0.086 & -0.026 & -0.008 & 0.0004 & 0.000 \\
\hline & $(0.172)$ & $(0.171)$ & $(0.242)$ & $(0.07)$ & $(0.241)$ & $(0.071)$ \\
\hline \multicolumn{7}{|c|}{ Employment status (Reference category unemployed) } \\
\hline \multirow[t]{2}{*}{ Employed } & 0.064 & 0.082 & 0.122 & 0.036 & 0.147 & 0.043 \\
\hline & $(0.076)$ & $(0.076)$ & $(0.105)$ & 0.031 & $(0.105)$ & $(0.031)$ \\
\hline \multicolumn{7}{|c|}{ Own business (Reference category No) } \\
\hline \multirow[t]{2}{*}{ Yes } & 0.051 & 0.048 & 0.152 & 0.045 & 0.155 & 0.045 \\
\hline & $(0.072)$ & $(0.072)$ & $(0.116)$ & 0.034 & $(0.116)$ & $(0.034)$ \\
\hline \multicolumn{7}{|c|}{ Agriculture land (Reference category No) } \\
\hline \multirow[t]{2}{*}{ Yes } & 0.014 & 0.014 & 0.0335 & 0.027 & 0.033 & 0.026 \\
\hline & $(0.062)$ & $(0.062)$ & $(0.093)$ & 0.023 & $(0.090)$ & $(0.023)$ \\
\hline \multicolumn{7}{|c|}{ Farmers (Reference category No) } \\
\hline \multirow[t]{2}{*}{ Yes } & 0.009 & 0.004 & -0.066 & 0.002 & -0.070 & 0.0006 \\
\hline & $(0.090)$ & $(0.089)$ & $(0.110)$ & 0.025 & $(0.110)$ & $(0.025)$ \\
\hline \multicolumn{7}{|c|}{ Interaction term (agriculture land and farmers) } \\
\hline \multirow[t]{2}{*}{ Iteractionterm } & $0.225^{* *}$ & $0.219 * *$ & 0.204 & & 0.195 & \\
\hline & $(0.110)$ & $(0.110)$ & $(0.148)$ & & $(0.148)$ & \\
\hline \multicolumn{7}{|c|}{ Own house (Reference category No) } \\
\hline \multirow[t]{2}{*}{ Yes } & $0.261 * * *$ & $0.267 * * *$ & $0.410 * * *$ & 0.122 & $0.417 * * *$ & $0.123 * * *$ \\
\hline & $(0.060)$ & $(0.060)$ & $(0.078)$ & $(0.022)$ & $(0.078)$ & $(0.022)$ \\
\hline \multicolumn{7}{|c|}{ Household livestock (Reference category No) } \\
\hline \multirow[t]{2}{*}{ Yes } & 0.061 & 0.056 & 0.036 & 0.011 & 0.025 & 0.007 \\
\hline & $(0.074)$ & $(0.074)$ & $(0.108)$ & $(0.032)$ & $(0.108)$ & $(0.232)$ \\
\hline \multicolumn{7}{|c|}{ Household borrowing (Reference category No) } \\
\hline Yes & $-0.141 * * *$ & $-0.147 * * *$ & -0.042 & -0.012 & -0.043 & -0.012 \\
\hline & $(0.053)$ & $(0.053)$ & $(0.071)$ & $(0.021)$ & $(0.071)$ & $(0.021)$ \\
\hline Household asse & ion) (Referer & ce category I & & & & \\
\hline Yes & $-1.185^{* *}$ & $-1.149 * *$ & $-2.887 * * *$ & 0.003 & $-2.865^{* * *}$ & 0.004 \\
\hline & $(0.559)$ & $(0.557)$ & $(0.887)$ & $(0.023)$ & $(0.877)$ & $(0.023)$ \\
\hline Household log & apita consum & tion & & & & \\
\hline Consumption & $0.252 * * *$ & $0.254 * * *$ & $0.214 * *$ & $0.117 * * *$ & $0.201 * *$ & $0.113 * * *$ \\
\hline & $(0.058)$ & $(0.057)$ & $(0.088)$ & $(0.018)$ & $(0.085)$ & $(0.018)$ \\
\hline Interaction term & mption and a & set) & & & & \\
\hline Interaction term & $0.154 * *$ & $0.150 * *$ & $0.376 * * *$ & & $0.373 * * *$ & \\
\hline & $(0.072)$ & $(0.071)$ & $(0.116)$ & & $(0.114)$ & \\
\hline Food insecurity & nce category & No) & & & & \\
\hline Yes & $-0.256^{* * *}$ & $-0.253^{* * *}$ & $-0.248 * * *$ & $-0.073 * * *$ & $-0.245^{* * *}$ & $-0.072 * * *$ \\
\hline & $(0.051)$ & $(0.051)$ & $(0.075)$ & $(0.022)$ & $(0.075)$ & $(0.022)$ \\
\hline Physical injury & ice category I & & & & & \\
\hline Yes & $-0.148 * * *$ & $-0.146^{* * *}$ & $-0.147 *$ & $-0.043^{*}$ & $-0.145^{*}$ & $-0.043^{*}$ \\
\hline & $(0.052)$ & $(0.052)$ & $(0.078)$ & $(0.023)$ & $(0.078)$ & $(0.023)$ \\
\hline Water facility & e category ur & improved) & & & & \\
\hline Improved & 0.076 & 0.079 & 0.100 & 0.029 & 0.106 & 0.031 \\
\hline & $(0.084)$ & $(0.084)$ & $(0.118)$ & $(0.034)$ & $(0.118)$ & $(0.034)$ \\
\hline & & & & & & \\
\hline
\end{tabular}




\begin{tabular}{|c|c|c|c|c|c|c|}
\hline \multirow[t]{2}{*}{ Variables } & \multirow{2}{*}{$\begin{array}{l}\text { Model 1 }^{\mathrm{a}} \\
\text { Coefficient }\end{array}$} & \multirow{2}{*}{$\begin{array}{l}\text { Model } 2^{b} \\
\text { Coefficient }\end{array}$} & \multicolumn{2}{|l|}{ Model $3^{\mathrm{c}}$} & \multicolumn{2}{|l|}{ Model $4^{\mathrm{d}}$} \\
\hline & & & Coefficient & Ave. $\mathrm{ME}^{\mathrm{f}}$ & Coefficient & Ave. ME \\
\hline \multicolumn{7}{|c|}{ Sanitation facility (reference category unimproved) } \\
\hline \multirow{2}{*}{ Improved } & 0.038 & 0.037 & 0.098 & 0.029 & 0.098 & 0.029 \\
\hline & $(0.051)$ & $(0.050)$ & $(0.073)$ & $(0.021)$ & $(0.073)$ & $(0.021)$ \\
\hline \multicolumn{7}{|c|}{ Provinces (reference category Punjab) } \\
\hline \multirow[t]{2}{*}{ Sindh } & -0.029 & -0.031 & $-0.211 * * *$ & $-0.070 * * *$ & $-0.207 * * *$ & $-0.069 * * *$ \\
\hline & $(0.056)$ & $(0.056)$ & $(0.074)$ & $(0.024)$ & $(0.074)$ & $(0.024)$ \\
\hline \multirow[t]{2}{*}{$\mathrm{KP}$} & $0.738 * * *$ & $0.751 * * *$ & $0.664 * * *$ & $0.181 * * *$ & $0.682 * * *$ & $0.184 * * *$ \\
\hline & $(0.068)$ & $(0.068)$ & $(0.105)$ & $(0.025)$ & $(0.104)$ & $(0.025)$ \\
\hline \multirow[t]{2}{*}{ Balochistan } & $0.385 * * *$ & $0.398 * * *$ & $1.364 * * *$ & $0.284 * * *$ & $1.385 * * *$ & $0.287 * * *$ \\
\hline & $(0.063)$ & $(0.063)$ & $(0.163)$ & $(0.022)$ & $(0.163)$ & $(0.022)$ \\
\hline \multicolumn{7}{|c|}{ Region (referencecategory Rural) } \\
\hline \multirow[t]{2}{*}{ Urban } & $-0.235^{* * *}$ & $-0.233 * * *$ & $-0.208 * *$ & $-0.06 * *$ & $-0.200 * *$ & $-0.059 * *$ \\
\hline & $(0.060)$ & $(0.061)$ & $(0.087)$ & $(0.025)$ & $(0.087)$ & $(0.025)$ \\
\hline \multirow[t]{2}{*}{ Constant } & & & $-1.871 * *$ & & $-1.942 * * *$ & \\
\hline & & & $(0.742)$ & & $(0.736)$ & \\
\hline Cut1 & $1.284 * *$ & $1.397 * * *$ & & & & \\
\hline Cut2 & $2.195 * * *$ & $2.308 * * *$ & & & & \\
\hline Cut3 & $3.060 * * *$ & $3.173 * * *$ & & & & \\
\hline Cut4 & $3.654 * * *$ & $3.768 * * *$ & & & & \\
\hline Cut5 & $4.495 * * *$ & $4.610 * * *$ & & & & \\
\hline Cut6 & $4.997 * * *$ & $5.112 * * *$ & & & & \\
\hline Cut7 & $5.522 * * *$ & $5.638 * * *$ & & & & \\
\hline Cut8 & $6.274 * * *$ & $6.400 * * *$ & & & & \\
\hline Cut9 & $6.552 * * *$ & $6.682 * * *$ & & & & \\
\hline \multicolumn{7}{|l|}{ Diagnostic test } \\
\hline Wald chi2(27) & 562.46 & 568.82 & 388.19 & & 396.83 & \\
\hline Prob > chi 2 & 0.000 & 0.000 & 0.000 & & 0.000 & \\
\hline Pseudo R2 & 0.08 & 0.08 & 0.16 & & 0.16 & \\
\hline Log pseudolikelihood & -315.390 & -315.212 & -101.436 & & -101.366 & \\
\hline Numberofobs. & 3,015 & 3,015 & 3,015 & 3,015 & 3,015 & 3,015 \\
\hline \multicolumn{7}{|c|}{ Robust standard errors in parentheses; $* * * p<0.01, * * p<0.05, * p<0.1$} \\
\hline$a=$ Model 1: Ordered pro & it model scale & 1 to scale-10( & subjective pove & ty gender clo & ssification less & he 18 years), \\
\hline$b=$ Model 2: Ordered prob & it model scale- & 1 to scale-10 (s & ubjective pover & y gender cla & sification less & he 6 years), \\
\hline $\begin{array}{l}c=\text { Model 3: Probit mo } \\
\text { classification less than } 18 y\end{array}$ & $\begin{array}{l}\text { del based on } \\
\text { ears) }\end{array}$ & scale $1-2$ as & poor and 3-10 & as non-poc & (subjective & overty gender \\
\hline $\begin{array}{l}d=\text { Model 4: Probit mo } \\
\text { classification less than } 6 \text { ye }\end{array}$ & $\begin{array}{l}\text { del based on } \\
\text { ars) }\end{array}$ & scale 1-2 as & poor and 3-10 & as non-poc & (subjective & overty gender \\
\hline \multicolumn{7}{|l|}{$f=$ average marginal effect } \\
\hline
\end{tabular}

\subsubsection{Determinants of objective poverty}

Table 2.6 shows the results of objective poverty based on $\$ 1.25$ and $\$ 1$ per day. Being non-poor is coded 1 so that a positive coefficient means the covariate is associated with less poverty. Many findings of the objective poverty approaches are in line with the subjective poverty measure, but still some results are contradictory to the subjective poverty approach and need further explanation. Specifically, with the increase of household size, the conventional poverty escalates 
while the households become better off subjectively. In subjective term, an additional member of household is considered as an asset, and adds value to the household. While in monetary sense, the household become worse off with the increase of household size. Importantly, we have classified children based on gender. The findings confirm that boys are preferred over girls in both age groups objectively, implying that boys are given an economic values in monetary term relatively. The reason could be due to less household size having male children due to gender bias. However, subjectively, during young age, boys are also preferred, but with increasing age the difference between genders diminishes subjectively. In addition, household borrowing is considered as a burden subjectively and has a statistically negative impact on subjective wellbeing; nevertheless, it has an insignificant positive impact on household objective poverty.

Another important contradiction between findings of the two approaches comes up from the regional and provincial differences. The subjective poverty of households living in rural areas is lower, while it is higher for urban areas. Nevertheless, more chances of employment and income generation opportunities exist in urban localities. Hence, we expect that poverty will decline in monetary approach. However, this is opposite to the subjective approach. Other pivotal results of the two approaches are that food insecurity has a significant negative impact on households' subjective as well as objective well-being. For instance, one percent increase in food insecurity leads to 7.3 percentage point and 5.3 percentage points' higher probability of experiencing subjective and objective poverty, respectively. Regarding physical insecurity, we have contrasting results for both poverty approaches. For example, physical insecurity imparts significant negative impact on well-being in the subjective approach. However, the impact of physical insecurity is not statistically significant in the monetary approach. The reason behind this could be that physical insecurity imparts mental and psychological stress on households, while objectively it has a lesser impact due to ease of compensation or migration from the affected region. 


\section{Table 2.6 Objective poverty determinants results}

\begin{tabular}{|c|c|c|c|c|c|c|c|c|}
\hline \multirow[b]{3}{*}{ Variables } & \multicolumn{4}{|c|}{$\$ 1.25$ per day } & \multicolumn{3}{|l|}{$\$ 1$ per day } & \\
\hline & \multicolumn{2}{|l|}{ Model 1} & \multicolumn{2}{|l|}{ Model 2} & \multicolumn{2}{|l|}{ Model 3} & \multicolumn{2}{|l|}{ Model 4} \\
\hline & Coefficient & Ave. ME & Coeff. & Ave. ME & Coeff. & Ave. ME & Coeff. & Ave. ME \\
\hline \multicolumn{9}{|c|}{ Household size as a continuous variables } \\
\hline Household size & $\begin{array}{l}-0.147 * * * \\
(0.016)\end{array}$ & $\begin{array}{l}-0.050 * * * \\
(0.005)\end{array}$ & $\begin{array}{l}-0.131 * * * \\
(0.014)\end{array}$ & $\begin{array}{l}-0.045 * * * \\
(0.004)\end{array}$ & $\begin{array}{l}-0.160 * * * \\
(0.015)\end{array}$ & $\begin{array}{l}-0.044 * * * \\
(0.004)\end{array}$ & $\begin{array}{l}-0.147 * * * \\
(0.014)\end{array}$ & $\begin{array}{l}-0.044 * * * \\
(0.004)\end{array}$ \\
\hline \multicolumn{9}{|c|}{ Gender classification } \\
\hline $\begin{array}{l}\text { Girls }<18 \\
\text { years }\end{array}$ & $\begin{array}{l}0.046 * * \\
(0.021)\end{array}$ & $\begin{array}{l}0.015 * * \\
(0.007)\end{array}$ & & & $(0.022)$ & $(0.007)$ & & \\
\hline $\begin{array}{l}\text { Boys }<18 \\
\text { years }\end{array}$ & $\begin{array}{l}0.052 * * \\
(0.021)\end{array}$ & $\begin{array}{l}0.018 * * \\
(0.007)\end{array}$ & & & $\begin{array}{l}0.064 * * * \\
(0.022)\end{array}$ & $\begin{array}{l}0.019 * * \\
(0.006)\end{array}$ & & \\
\hline Girls $<6$ years & & & $\begin{array}{l}0.045 \\
(0.038)\end{array}$ & $\begin{array}{l}0.015 \\
(0.013)\end{array}$ & & & $\begin{array}{l}0.037 \\
(0.039)\end{array}$ & $\begin{array}{l}0.011 \\
(0.012)\end{array}$ \\
\hline Boys $<6$ years & & & $\begin{array}{l}0.067 * \\
(0.037)\end{array}$ & $\begin{array}{l}0.023 * \\
(0.012)\end{array}$ & & & $\begin{array}{l}0.072 * \\
(0.038)\end{array}$ & $\begin{array}{l}0.022 * * \\
(0.011)\end{array}$ \\
\hline \multicolumn{9}{|c|}{ Age of household head } \\
\hline age & $\begin{array}{l}-0.002 \\
(0.012)\end{array}$ & $\begin{array}{l}-0.0007 \\
(0.000)\end{array}$ & $\begin{array}{l}0.003 \\
(0.012)\end{array}$ & $\begin{array}{l}0.001 \\
(0.004)\end{array}$ & $\begin{array}{l}-0.000 \\
(0.012)\end{array}$ & $\begin{array}{l}-0.000 \\
(0.003)\end{array}$ & $\begin{array}{l}0.005 \\
(0.012)\end{array}$ & $\begin{array}{l}0.001 \\
(0.003)\end{array}$ \\
\hline Age squared & $\begin{array}{l}5.14 \mathrm{e}-05 \\
(0.0001)\end{array}$ & $\begin{array}{l}0.000 \\
(0.000)\end{array}$ & $\begin{array}{l}-7.65 \mathrm{e}-06 \\
(0.0001)\end{array}$ & $\begin{array}{l}0.000 \\
(0.000)\end{array}$ & $\begin{array}{l}8.28 \mathrm{e}-05 \\
(0.0002)\end{array}$ & $\begin{array}{l}0.000 \\
(0.000)\end{array}$ & $\begin{array}{l}2.47 \mathrm{e}-05 \\
(0.0002)\end{array}$ & $\begin{array}{l}0.000 \\
(0.000)\end{array}$ \\
\hline \multicolumn{9}{|c|}{ Household head education (years of schooling as a continuous variable) } \\
\hline Schooling & $\begin{array}{l}0.055^{* * * *} \\
(0.006)\end{array}$ & $\begin{array}{l}0.018 * * * \\
(0.002)\end{array}$ & $\begin{array}{l}0.053 * * * \\
(0.006)\end{array}$ & $\begin{array}{l}0.018 * * * \\
(0.002)\end{array}$ & $\begin{array}{l}0.053 * * * \\
(0.007)\end{array}$ & $\begin{array}{l}0.016 * * * \\
(0.002)\end{array}$ & $\begin{array}{l}0.052 * * * \\
(0.007)\end{array}$ & $\begin{array}{l}0.015 * * * \\
(0.002)\end{array}$ \\
\hline \multicolumn{9}{|c|}{ Marital status (Reference category married) } \\
\hline Divorced & $\begin{array}{l}-0.054 \\
(0.132)\end{array}$ & $\begin{array}{l}-.018 \\
(0.045)\end{array}$ & $\begin{array}{l}-0.058 \\
(0.133)\end{array}$ & $\begin{array}{l}-0.019 \\
(0.045)\end{array}$ & $\begin{array}{l}-0.016 \\
(0.135)\end{array}$ & $\begin{array}{l}-0.005 \\
(0.041)\end{array}$ & $\begin{array}{l}-0.020 \\
(0.136)\end{array}$ & $\begin{array}{l}-0.006 \\
(0.041)\end{array}$ \\
\hline Single & $\begin{array}{l}-0.154 \\
(0.216)\end{array}$ & $\begin{array}{l}0.052 \\
(0.073)\end{array}$ & $\begin{array}{l}-0.167 \\
(0.217)\end{array}$ & $\begin{array}{l}-0.057 \\
(0.074)\end{array}$ & $\begin{array}{l}-0.186 \\
(0.217)\end{array}$ & $\begin{array}{l}0.058 \\
(0.070)\end{array}$ & $\begin{array}{l}-0.197 \\
(0.217)\end{array}$ & $\begin{array}{l}-0.062 \\
(0.070)\end{array}$ \\
\hline \multicolumn{9}{|c|}{ Employment status (Reference category unemployed) } \\
\hline Employed & $\begin{array}{l}0.0334 \\
(0.103)\end{array}$ & $\begin{array}{l}0.011 \\
(0.035)\end{array}$ & $\begin{array}{l}0.070 \\
(0.102)\end{array}$ & $\begin{array}{l}0.024 \\
(0.035)\end{array}$ & $\begin{array}{l}0.103 \\
(0.101)\end{array}$ & $\begin{array}{l}0.031 \\
(0.030)\end{array}$ & $\begin{array}{l}0.135 \\
(0.101)\end{array}$ & $\begin{array}{l}0.041 \\
(0.030)\end{array}$ \\
\hline \multicolumn{9}{|c|}{ Own business (Reference category No) } \\
\hline Yes & 0.148 & 0.051 & 0.141 & 0.048 & $0.247 * *$ & $0.075 * *$ & $0.236 * *$ & $0.072 * *$ \\
\hline
\end{tabular}




\begin{tabular}{|c|c|c|c|c|c|c|c|c|}
\hline \multirow[b]{3}{*}{ Variables } & \multicolumn{4}{|c|}{$\$ 1.25$ per day } & \multicolumn{4}{|c|}{$\$ 1$ per day } \\
\hline & \multicolumn{2}{|l|}{ Model 1} & \multicolumn{2}{|l|}{ Model 2} & \multicolumn{2}{|c|}{ Model 3} & \multicolumn{2}{|l|}{ Model 4} \\
\hline & Coefficient & Ave. ME & Coeff. & Ave. ME & Coeff. & Ave. ME & Coeff. & Ave. ME \\
\hline & $(0.103)$ & $(0.035)$ & $(0.103)$ & $(0.035)$ & $(0.109)$ & $(0.033)$ & $(0.109)$ & $(0.033)$ \\
\hline \multicolumn{9}{|c|}{ Agriculture land (Reference category No) } \\
\hline Yes & $\begin{array}{l}0.110 \\
(0.085)\end{array}$ & $\begin{array}{l}0.045^{*} \\
(0.024)\end{array}$ & $\begin{array}{l}0.113 \\
(0.085)\end{array}$ & $\begin{array}{l}0.045^{*} \\
(0.024)\end{array}$ & $\begin{array}{l}-0.0318 \\
(0.084)\end{array}$ & $\begin{array}{l}0.007 \\
(0.021)\end{array}$ & $\begin{array}{l}-0.028 \\
(0.084)\end{array}$ & $\begin{array}{l}0.007 \\
(0.021)\end{array}$ \\
\hline \multicolumn{9}{|c|}{ Farmer (Reference category No) } \\
\hline Yes & $\begin{array}{l}-0.062 \\
(0.109)\end{array}$ & $\begin{array}{l}-0.011 \\
(0.027)\end{array}$ & $\begin{array}{l}-0.073 \\
(0.108)\end{array}$ & $\begin{array}{l}-0.016 \\
(0.027)\end{array}$ & $\begin{array}{l}-0.175 \\
(0.107)\end{array}$ & $\begin{array}{l}-0.032 \\
(0.025)\end{array}$ & $\begin{array}{l}-0.186^{*} \\
(0.106)\end{array}$ & $\begin{array}{l}-0.036 \\
(0.025)\end{array}$ \\
\hline \multicolumn{9}{|c|}{ Interaction term (farmer and agriculture land) } \\
\hline $\begin{array}{l}\text { Interaction } \\
\text { term }\end{array}$ & $\begin{array}{l}0.075 \\
(0.137)\end{array}$ & & $\begin{array}{l}0.065 \\
(0.136)\end{array}$ & & $(0.137)$ & & $\begin{array}{l}0.171 \\
(0.136)\end{array}$ & \\
\hline \multicolumn{9}{|c|}{ Own house (Reference category No) } \\
\hline Yes & $\begin{array}{l}0.256 * * * \\
(0.077)\end{array}$ & $\begin{array}{l}0.087 * * * \\
(0.026)\end{array}$ & $\begin{array}{l}0.259 * * * \\
(0.076)\end{array}$ & $\begin{array}{l}0.089 * * * \\
(0.026)\end{array}$ & $\begin{array}{l}0.300 * * * \\
(0.076)\end{array}$ & $\begin{array}{l}0.091 * * * \\
(0.022)\end{array}$ & $\begin{array}{l}0.302 * * * \\
(0.075)\end{array}$ & $\begin{array}{l}0.092 * * * \\
(0.022)\end{array}$ \\
\hline \multicolumn{9}{|c|}{ Livestock (Reference category No) } \\
\hline Yes & $\begin{array}{l}-0.095 \\
(0.093)\end{array}$ & $\begin{array}{l}-0.032 \\
(0.032)\end{array}$ & $\begin{array}{l}-0.097 \\
(0.094)\end{array}$ & $\begin{array}{l}-0.033 \\
(0.032)\end{array}$ & $\begin{array}{l}0.140 \\
(0.094)\end{array}$ & $\begin{array}{l}0.042 \\
(0.028)\end{array}$ & $\begin{array}{l}0.134 \\
(0.094)\end{array}$ & $\begin{array}{l}0.041 \\
(0.028)\end{array}$ \\
\hline \multicolumn{9}{|c|}{ Borrowing (Reference category No) } \\
\hline Yes & $\begin{array}{l}0.028 \\
(0.069)\end{array}$ & $\begin{array}{l}0.009 \\
(0.023)\end{array}$ & $\begin{array}{l}0.025 \\
(0.069)\end{array}$ & $\begin{array}{l}0.008 \\
(0.023)\end{array}$ & $\begin{array}{l}-0.019 \\
(0.069)\end{array}$ & $\begin{array}{l}-0.005 \\
(0.021)\end{array}$ & $\begin{array}{l}-0.023 \\
(0.069)\end{array}$ & $\begin{array}{l}-0.007 \\
(0.021)\end{array}$ \\
\hline \multicolumn{9}{|c|}{ Household asset (television)(Reference category No) } \\
\hline Yes & $\begin{array}{l}0.492 * * * \\
(0.067)\end{array}$ & $\begin{array}{l}0.174 * * * \\
(0.024)\end{array}$ & $\begin{array}{l}0.490 * * * \\
(0.067)\end{array}$ & $0.173 * * *$ & $\begin{array}{l}0.443 * * * \\
(0.068)\end{array}$ & $\begin{array}{l}0.138 * * * \\
(0.021)\end{array}$ & $\begin{array}{l}0.443 * * * \\
(0.068)\end{array}$ & $\begin{array}{l}0.139 * * * \\
(0.021)\end{array}$ \\
\hline \multicolumn{9}{|c|}{ Food insecurity (Reference category secure) } \\
\hline Food insecure & $\begin{array}{l}-0.156^{* *} \\
(0.068)\end{array}$ & $\begin{array}{l}-0.053 * * \\
(0.023)\end{array}$ & $\begin{array}{l}-0.148 * * \\
(0.068)\end{array}$ & $\begin{array}{l}-0.051 * * \\
(0.023)\end{array}$ & $\begin{array}{l}-0.143 * * \\
(0.069)\end{array}$ & $\begin{array}{l}-0.043 * * \\
(0.021)\end{array}$ & $\begin{array}{l}-0.136^{*} \\
(0.069)\end{array}$ & $\begin{array}{l}-0.041 * * \\
(0.021)\end{array}$ \\
\hline \multicolumn{9}{|c|}{ Physical injury (Reference category No injury) } \\
\hline injury & $\begin{array}{l}-0.099 \\
(0.073)\end{array}$ & $\begin{array}{l}-0.034 \\
(0.025)\end{array}$ & $\begin{array}{l}-0.092 \\
(0.073)\end{array}$ & $\begin{array}{l}-0.032 \\
(0.025)\end{array}$ & $\begin{array}{l}-0.071 \\
(0.072)\end{array}$ & $\begin{array}{l}-0.021 \\
(0.022)\end{array}$ & $\begin{array}{l}-0.065 \\
(0.072)\end{array}$ & $\begin{array}{l}-0.019 \\
(0.030)\end{array}$ \\
\hline \multicolumn{9}{|c|}{ Water facility (Reference category unimproved) } \\
\hline Improved & $\begin{array}{l}0.003 \\
(0.108)\end{array}$ & $\begin{array}{l}0.002 \\
(0.024)\end{array}$ & $\begin{array}{l}0.012 \\
(0.107)\end{array}$ & $\begin{array}{l}0.004 \\
(0.036)\end{array}$ & $\begin{array}{l}0.104 \\
(0.098)\end{array}$ & $\begin{array}{l}0.031 \\
(0.029)\end{array}$ & $\begin{array}{l}0.114 \\
(0.098)\end{array}$ & $\begin{array}{l}0.034 \\
(0.030)\end{array}$ \\
\hline
\end{tabular}




\begin{tabular}{|c|c|c|c|c|c|c|c|c|}
\hline \multirow[b]{3}{*}{ Variables } & \multicolumn{4}{|c|}{$\$ 1.25$ per day } & \multicolumn{4}{|c|}{$\$ 1$ per day } \\
\hline & \multicolumn{2}{|l|}{ Model 1} & \multicolumn{2}{|l|}{ Model 2} & \multicolumn{2}{|c|}{ Model 3} & \multicolumn{2}{|l|}{ Model 4} \\
\hline & Coefficient & Ave. ME & Coeff. & Ave. ME & Coeff. & Ave. ME & Coeff. & Ave. ME \\
\hline Improved & $\begin{array}{l}0.179 * * * \\
(0.065)\end{array}$ & $\begin{array}{l}0.016^{* * * *} \\
(0.022)\end{array}$ & $\begin{array}{l}0.172 * * * \\
(0.065)\end{array}$ & $\begin{array}{l}0.059 * * * \\
(0.022)\end{array}$ & $\begin{array}{l}0.281^{* * * *} \\
(0.065)\end{array}$ & $\begin{array}{l}0.085 * * * \\
(0.019)\end{array}$ & $\begin{array}{l}0.276 * * * \\
(0.065)\end{array}$ & $\begin{array}{l}0.084 * * * \\
(0.019)\end{array}$ \\
\hline \multicolumn{9}{|c|}{ Provinces (Reference category Punjab) } \\
\hline Sindh & $\begin{array}{l}-0.046 \\
(0.071)\end{array}$ & $\begin{array}{l}-0.016 \\
(0.025)\end{array}$ & $\begin{array}{l}-0.030 \\
(0.071)\end{array}$ & $\begin{array}{l}-0.010 \\
(0.024)\end{array}$ & $\begin{array}{l}0.032 \\
(0.072)\end{array}$ & $\begin{array}{l}0.009 \\
(0.022)\end{array}$ & $\begin{array}{l}0.043 \\
(0.072)\end{array}$ & $\begin{array}{l}0.013 \\
(0.022)\end{array}$ \\
\hline $\mathrm{KP}$ & $\begin{array}{l}0.173 * * \\
(0.087)\end{array}$ & $\begin{array}{l}0.059 * * \\
(0.029)\end{array}$ & $\begin{array}{l}0.183^{* *} \\
(0.087)\end{array}$ & $\begin{array}{l}0.062^{* *} \\
(0.029)\end{array}$ & $\begin{array}{l}0.202 * * \\
(0.091)\end{array}$ & $\begin{array}{l}0.060 * * \\
(0.026)\end{array}$ & $\begin{array}{l}0.211 * * \\
(0.091)\end{array}$ & $\begin{array}{l}0.063^{* *} \\
(0.026)\end{array}$ \\
\hline Baluchistan & $\begin{array}{l}0.226 * * \\
(0.098)\end{array}$ & $\begin{array}{l}0.077 * * \\
(0.033)\end{array}$ & $\begin{array}{l}0.254 * * * \\
(0.098)\end{array}$ & $\begin{array}{l}0.086 * * * \\
(0.033)\end{array}$ & $\begin{array}{l}0.368^{* * * *} \\
(0.108)\end{array}$ & $\begin{array}{l}0.105^{* * *} * \\
(0.029)\end{array}$ & $\begin{array}{l}0.394 * * * \\
(0.109)\end{array}$ & $\begin{array}{l}0.113 * * * \\
(0.029)\end{array}$ \\
\hline \multicolumn{9}{|c|}{ Region (Reference category rural) } \\
\hline Urban & $\begin{array}{l}0.002 \\
(0.080)\end{array}$ & $\begin{array}{l}0.0008 \\
(0.027)\end{array}$ & $\begin{array}{l}0.010 \\
(0.081)\end{array}$ & $\begin{array}{l}0.003 \\
(0.027)\end{array}$ & $\begin{array}{l}0.002 \\
(0.081)\end{array}$ & $\begin{array}{l}0.0008 \\
(0.024)\end{array}$ & $\begin{array}{l}0.008 \\
(0.082)\end{array}$ & $\begin{array}{l}0.002 \\
(0.025)\end{array}$ \\
\hline Constant & $\begin{array}{l}-0.136 \\
(0.324)\end{array}$ & & $\begin{array}{l}-0.287 \\
(0.330)\end{array}$ & & $\begin{array}{l}0.033 \\
(0.323)\end{array}$ & & $\begin{array}{l}-0.116 \\
(0.330)\end{array}$ & \\
\hline \multicolumn{9}{|l|}{ Diagnostic test } \\
\hline Wald chi2(25) & 369.59 & & 364.51 & & 407.79 & & 400.06 & \\
\hline Prob > chi2 & 0.000 & & 0.000 & & 0.000 & & 0.000 & \\
\hline Pseudo R2 & 0.13 & & 0.13 & & 0.14 & & 0.14 & \\
\hline $\begin{array}{l}\text { Log } \\
\text { pseudolikeliho } \\
\text { od }\end{array}$ & -116.823 & & -117.151 & & -104.592 & & -104.876 & \\
\hline Observations & 3015 & & 3015 & & 3015 & & 3015 & \\
\hline
\end{tabular}

$a=$ Model 1: Probit model based on $\$ 1.25$ per day (objective poverty gender classification less than 18 years) $b=$ Model 2: Probit model based on $\$ 1.25$ per day (objective poverty gender classification less than 6 years) $c=$ Model 3: Probit model based on \$1 per day (objective poverty gender classification less than 18 years) $d=$ Model 4: Probit model based on $\$ 1$ per day (objective poverty gender classification less than 6 years) 


\subsubsection{Comparison of subjective poverty with objective poverty}

Table 2.7 shows the results of the multinomial probit model. As discussed in the methodological part, we have generated four categories of outcome variables: subjective non-poor-objective nonpoor combination (overall non-poor), subjective non-poor-objective poor combination (objective poor), subjective poor-objective non-poor combination (subjective poor), and subjective poorobjective poor combination (overall poor). The overall non-poor category is taken as a base outcome. Hence, we have three categories' findings relative to the base outcome discussed in detail as under.

In comparison to the overall non-poor, household size is associated with a higher likelihood of being poor objectively as well as overall poor and lower likelihood of being subjectively poor, consistent with the preceding results. Meanwhile, households with boys are more likely to be out of poverty objectively compared to the overall non-poor outcome group, whereas no significant differences is seen based on the gender classification subjectively. In addition, the chances of being out of overall poverty increases for the households consisting boys relatively to the base outcome, also consistent with the previous results. Likewise, the chances of subjective poor increases for divorced household head and declines for single marital status household head, compared to the overall non-poor, however, the results are insignificant. More education lowers, as expected, the likelihood of being objectively or subjectively poor.

In relative term, when the households lying below the poverty line have their own residence, the chances of being impoverished declines. Hence, owning a house contributes to the eradication of poverty in the society. Similarly, improved sanitation facilities increase significantly the wellbeing of households that are both objectively poor and over all poor. However, the coefficients of subject poor households are insignificant. Thus improving the sanitation system for the poor has much value relatively. Moreover, farmers' households having their own land, the payoffs are high for the poor households, however statistically insignificant. The statistical insignificance could be due to Pakistan being an agriculture country, where household living above the poverty line usually have control over agriculture land. The payoffs of overall poor employed household head regarding poverty reduction are statistically significant relatively, but the results for the other categories are not significant. Similarly, the overall poor households having their own business are less likely to be poor. Interestingly, the impact of livestock on the well-being of four 
categories is surprising. The households, which own livestock are more likely to be poor compared to the base non-poor category. This indicates that the livestock are the means of livelihood of poor, but not enough to improve the well-being of the poor. In the same way, the impact of household borrowing in reducing poverty is the same on all four categories.

Physical insecurity affects individuals mentally and psychologically more than, it does economically. The findings delineate that household living below the poverty line, incidents of physical insecurity increases poverty. This indicates that above the poverty line, household have more capacity to cope with the immediate effect of terrorist activities. They have better coping options both in the short and long run. Household asset is also an important contributor in alleviating poverty of individuals. Likewise, both subjective poor and overall poor are more likely to be food vulnerable compared to the non-poor households.

Table 2.7 Comparison of subjective poverty and objective poverty (\$1.25)

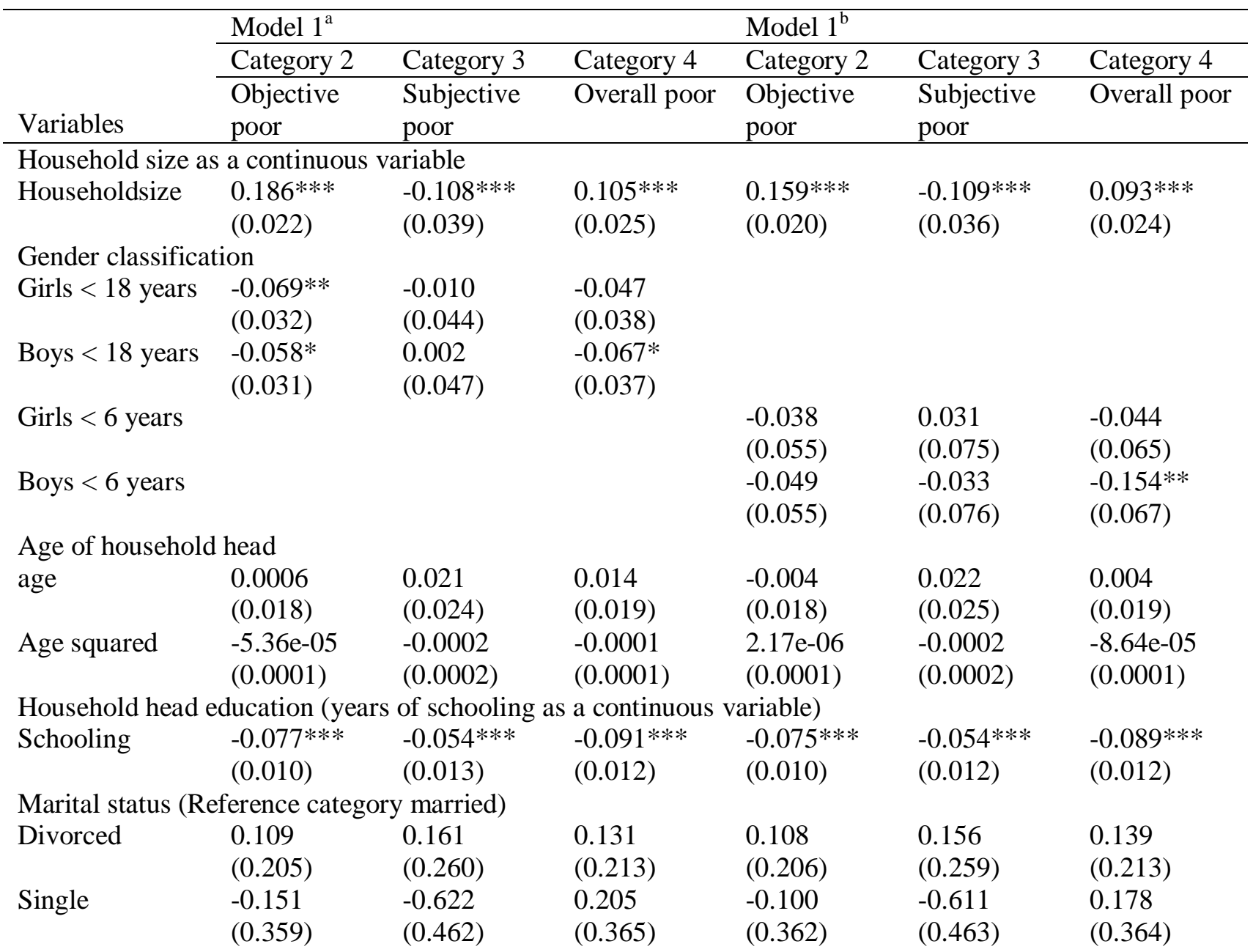


Employment status (Reference category unemployed)

$\begin{array}{lllllll}\text { Employed } & 0.098 & 0.081 & -0.214 & 0.052 & 0.074 & -0.261^{*} \\ & (0.160) & (0.184) & (0.159) & (0.160) & (0.183) & (0.157)\end{array}$

Own business (Reference category No)

$\begin{array}{lllllll}\text { Yes } & -0.189 & -0.255 & -0.376^{* *} & -0.179 & -0.255 & -0.375^{* *} \\ & (0.151) & (0.192) & (0.188) & (0.151) & (0.191) & (0.188)\end{array}$

Agriculture land (Reference category No)

$\begin{array}{lllllll}\text { Yes } & -0.226^{*} & -0.199 & -0.135 & -0.230^{*} & -0.205 & -0.141 \\ & (0.127) & (0.161) & (0.149) & (0.127) & (0.161) & (0.148)\end{array}$

Farmer (Reference category No)

$\begin{array}{lllllll}\text { Yes } & -0.031 & -0.069 & 0.182 & -0.015 & -0.069 & 0.186 \\ & (0.164) & (0.208) & (0.182) & (0.163) & (0.208) & (0.181)\end{array}$

Interaction term (farmer and agriculture land)

$\begin{array}{lllllll}\text { Interaction term } & -0.081 & -0.356 & -0.329 & -0.070 & -0.346 & -0.306 \\ & (0.203) & (0.270) & (0.234) & (0.203) & (0.270) & (0.232)\end{array}$

Own house (Reference category No)

$\begin{array}{lllllll}\text { Yes } & -0.214 * & -0.442 * * * & -0.753 * * * & -0.214 * & -0.443 * * * & -0.761 * * * \\ & (0.115) & (0.143) & (0.132) & (0.115) & (0.142) & (0.132)\end{array}$

Livestock (Reference category No)

$\begin{array}{lllllll}\text { Yes } & 0.217 & 0.140 & 0.011 & 0.216 & 0.140 & 0.025 \\ & (0.138) & (0.187) & (0.165) & (0.139) & (0.187) & (0.166)\end{array}$

Household borrowing (Reference category No)

$\begin{array}{lllllll}\text { Yes } & -0.058 & 0.037 & 0.009 & -0.057 & 0.035 & 0.014 \\ & (0.106) & (0.125) & (0.116) & (0.106) & (0.124) & (0.117)\end{array}$

Household asset (television)(Reference category No)

\begin{tabular}{|c|c|c|c|c|c|c|}
\hline Yes & $\begin{array}{l}-0.696 * * * \\
(0.099)\end{array}$ & $\begin{array}{l}-0.228^{*} \\
(0.129)\end{array}$ & $\begin{array}{l}-0.600 \text { *** } \\
(0.120)\end{array}$ & $\begin{array}{l}-0.689 * * * \\
(0.099)\end{array}$ & $\begin{array}{l}-0.230 * \\
(0.130)\end{array}$ & $\begin{array}{l}-0.600 \text { **** } \\
(0.120)\end{array}$ \\
\hline \multicolumn{7}{|c|}{ Food insecurity (Reference category secure) } \\
\hline Food insecure & $\begin{array}{l}0.121 \\
(0.099)\end{array}$ & $\begin{array}{l}0.259^{* *} \\
(0.131)\end{array}$ & $\begin{array}{l}0.505^{* * *} * \\
(0.119)\end{array}$ & $\begin{array}{l}0.114 \\
(0.099)\end{array}$ & $\begin{array}{l}0.262 * * \\
(0.131)\end{array}$ & $\begin{array}{l}0.498 * * * \\
(0.119)\end{array}$ \\
\hline \multicolumn{7}{|c|}{ Physical injury (Reference category No injury) } \\
\hline injury & $\begin{array}{l}0.114 \\
(0.111)\end{array}$ & $\begin{array}{l}0.191 \\
(0.137)\end{array}$ & $\begin{array}{l}0.270 * * \\
(0.124)\end{array}$ & $\begin{array}{l}0.102 \\
(0.111)\end{array}$ & $\begin{array}{l}0.191 \\
(0.136)\end{array}$ & $\begin{array}{l}0.267 * * \\
(0.124)\end{array}$ \\
\hline
\end{tabular}

Water facility (Reference category unimproved)

\begin{tabular}{|c|c|c|c|c|c|c|}
\hline Improved & $\begin{array}{l}0.0327 \\
(0.162)\end{array}$ & $\begin{array}{l}-0.0775 \\
(0.203)\end{array}$ & $\begin{array}{l}-0.0983 \\
(0.181)\end{array}$ & $\begin{array}{l}0.0195 \\
(0.161)\end{array}$ & $\begin{array}{l}-0.0809 \\
(0.203)\end{array}$ & $\begin{array}{l}-0.106 \\
(0.180)\end{array}$ \\
\hline \multicolumn{7}{|c|}{ Sanitation facility (Reference category unimproved) } \\
\hline Improved & $\begin{array}{l}-0.183^{*} \\
(0.0962)\end{array}$ & $\begin{array}{l}-0.0744 \\
(0.123)\end{array}$ & $\begin{array}{l}-0.382 * * * \\
(0.117)\end{array}$ & $\begin{array}{l}-0.171^{*} \\
(0.0959)\end{array}$ & $\begin{array}{l}-0.0730 \\
(0.123)\end{array}$ & $\begin{array}{l}-0.378^{* * * *} \\
(0.117)\end{array}$ \\
\hline \multicolumn{7}{|c|}{ Provinces (Reference category Punjab) } \\
\hline Sindh & $\begin{array}{l}0.124 \\
(0.105)\end{array}$ & $\begin{array}{l}0.389 * * * \\
(0.135)\end{array}$ & $\begin{array}{l}0.272 * * \\
(0.117)\end{array}$ & $\begin{array}{l}0.0937 \\
(0.105)\end{array}$ & $\begin{array}{l}0.378 * * * \\
(0.135)\end{array}$ & $\begin{array}{l}0.262^{* *} \\
(0.117)\end{array}$ \\
\hline KP & $\begin{array}{l}-0.0568 \\
(0.126)\end{array}$ & $\begin{array}{l}-0.659 \text { *** } \\
(0.175)\end{array}$ & $\begin{array}{l}-0.977 * * * \\
(0.164)\end{array}$ & $\begin{array}{l}-0.0624 \\
(0.126)\end{array}$ & $\begin{array}{l}-0.663 \text { *** } \\
(0.175)\end{array}$ & $\begin{array}{l}-1.009 * * * \\
(0.164)\end{array}$ \\
\hline Baluchistan & $\begin{array}{l}-0.165 \\
(0.141)\end{array}$ & $\begin{array}{l}-1.476^{* * * *} \\
(0.252)\end{array}$ & $\begin{array}{l}-1.967 * * * \\
(0.287)\end{array}$ & $\begin{array}{l}-0.196 \\
(0.141)\end{array}$ & $\begin{array}{l}-1.479 * * * \\
(0.253)\end{array}$ & $\begin{array}{l}-2.002 * * * \\
(0.287)\end{array}$ \\
\hline \multicolumn{7}{|c|}{ Region (Reference category rural) } \\
\hline Urban & $\begin{array}{l}-0.128 \\
(0.121)\end{array}$ & $\begin{array}{l}0.0858 \\
(0.146)\end{array}$ & $\begin{array}{l}0.249 * \\
(0.140)\end{array}$ & $\begin{array}{l}-0.136 \\
(0.122)\end{array}$ & $\begin{array}{l}0.0843 \\
(0.146)\end{array}$ & $\begin{array}{l}0.232^{*} \\
(0.140)\end{array}$ \\
\hline Constant & $\begin{array}{l}-0.00351 \\
(0.500)\end{array}$ & $\begin{array}{l}-0.0147 \\
(0.632)\end{array}$ & $\begin{array}{l}0.352 \\
(0.537)\end{array}$ & $\begin{array}{l}0.110 \\
(0.509)\end{array}$ & $\begin{array}{l}-0.0465 \\
(0.648)\end{array}$ & $\begin{array}{l}0.615 \\
(0.546)\end{array}$ \\
\hline
\end{tabular}




\begin{tabular}{|c|c|c|}
\hline \multicolumn{3}{|l|}{ Diagnostic test } \\
\hline Wald chi2(75) & 713.81 & 708.66 \\
\hline Prob > chi2 & 0.000 & 0.000 \\
\hline $\begin{array}{l}\text { Log } \\
\text { pseudolikelihoo } \\
\text { d }\end{array}$ & -217.636 & -217.853 \\
\hline Observations & 3015 & 3015 \\
\hline
\end{tabular}

Finally, the Spearman's rank correlation result rejects the null hypothesis that the variables are independent. This confirms that subjective poverty and objective poverty measures are closely related, though some determinants are different in terms of statistical significance. The findings add to the existing literature that the subjective poverty approach is also important measure of poverty in addition to the objective poverty measure. Thus, subjective poverty should be considered, as it has more broad contents particularly in developing countries where the variables such as education, household size, physical security, and residential status have far greater impact on the lower segment of society relatively. Table 2.8 presents the Spearman's rank correlation results.

Table 2.8 Spearman's correlation matrix

\begin{tabular}{lccc}
\hline & $\begin{array}{l}\text { Subjective poverty } \\
\text { Predicted outcome(1)) }\end{array}$ & $\begin{array}{l}\text { Objective poverty (per } \\
\text { capita consumption) }\end{array}$ & $\begin{array}{l}\text { Subjective poverty } \\
(1-10)\end{array}$ \\
\hline $\begin{array}{l}\text { Subjective poverty(1- } \\
\text { 10) Pred outcome(1)) }\end{array}$ & 1.00 & & \\
$\begin{array}{l}\text { Objective poverty (per } \\
\text { capita consumption) }\end{array}$ & $0.48^{a}$ & 1.00 & \\
$\begin{array}{l}\text { Subjective poverty (1- } \\
10)\end{array}$ & $0.49^{a}$ & $0.26^{a}$ & 1.00 \\
\hline
\end{tabular}

Test of Ho: Variables are independent

$a_{* * *} p<0.01$

\subsection{Conclusion}

We analyzed the determinants of subjective poverty in detail, and compared it with objective poverty. The subjective poverty approach consists of two cases. One is the ranking by individuals from the poorest to the richest. The other one is to generate poor and non-poor categories based on the ranking. Then we compared the determinants of subjective poverty with objective poverty line of $\$ 1.25$ and $\$ 1$ per day. The findings of subjective poverty approach 
complement the objective poverty, but the subjective poverty has more broad contents. We have contradictory findings for some of their determinants; such as household size, gender classification, physical and food insecurity and regional domains. In addition, the results of robustness check based on probit model are in line with the aforementioned measures. In comparing the two measures, we utilize the multinomial probit model after generating four nominal categories. The results also confirm these findings.

Keeping in view the above analyses, we highlight the possible implication of the study and suggest policy recommendation. First, subjective poverty approach is an important measure of poverty. Second, categorization of subjective poor captures well the impact of specific determinants. The payoff of higher education, own residence, physical security are large for the poor. In addition, the poor cannot cope with adverse situations. A small contribution of these predictors results in multiple effect for the poor due to much greater social and economic benefits. Therefore, promoting public programs such as rural education, housing policy, food policy, and security level should be in line with these findings. The local government should be involved to pinpoint the targeted groups based on subjective measure to solve their problems in a better manner. Similarly, there is a need to create opportunities for women such as education, right of inheritance, employment to come at par with their male counterpart. The security level of the poor should be given keen attention because the poor have limited coping strategies. 


\subsection{References}

Alkire, S. (2007). The Missing Dimensions of Poverty Data: Introduction to the Special Issue. Oxford Development Studies, 35(4), 347-359.

Camfield, L., Choudhury, K., \& Devine, J. (2009). Well-being, Happiness and Why Relationships Matter: Evidence from Bangladesh. Journal of Happiness Studies, 10(1), 71-91.

Cantril, H. (1965) The pattern of human concerns. Rutgers University Press, New Brunswick

Deaton, A. (2001). Computing prices and poverty rates in India, 1999-2000. Princeton, Research Programme in Development Studies.

Deaton, A. (2010). Price Indexes, Inequality, and the Measurement of World Poverty.The American Economic Review, 100(1), 3-34.

Deaton, A., \& Drèze, J. (2009).Food and Nutrition in India: Facts and Interpretations. Economic and Political Weekly, 44(7), 42-65.

Deaton, A., \& Heston, A. (2010).Understanding PPPs and PPP-based National Accounts. American Economic Journal: Macroeconomics, 2(4), 1-35

Deeming, C. (2013). Addressing the Social Determinants of Subjective Wellbeing: The Latest Challenge for Social Policy. Journal of Social Policy, 42(3), 541-565.

Diener, E., \& Biswas-Diener, R. (2002). Will money increase subjective well-being?.Social indicators research, 57(2), 119-169.

Diener, E., Oishi, S., \& Lucas, R. E. (2002).Subjective well-being: The science of happiness and life satisfaction.In C.R. Snyder \& S. J. Lopez (Ed.), Handbook of Positive Psychology. Oxford and New York : Oxford University Press.

Diener, E., Sandvik, E., Seidlitz, L., \& Diener, M. (1993).The relationship between income and subjective well-being: Relative or absolute? Social Indicators Research, 28(3), 195-223.

Dolan, P., Peasgood, T., \& White, M. (2008). Do we really know what makes us happy? A review of the economic literature on the factors associated with subjective well-being. Journal of Economic Psychology, 29(1), 94-122.

Garner, T. I., \& Vos, K. D. (1995). Income sufficiency v. poverty Results from the United States and The Netherlands. Journal of Population Economics, 8(2), 117-134.

Goedhart, T., Halberstadt, V., Kapteyn, A., \& Van Praag, B. (1977). The Poverty Line: Concept and Measurement.The Journal of Human Resources, 12(4), 503-520, doi:10.2307/145372 
Government of Pakistan (2014). Economic Survey 2013-14. Ministry of Finance. Islamabad.

Greene, W. H. (2011). Econometric Analysis (7th edition). ISBN-13, 978-0131395381.

International Labour Oragnisation (ILO), (2005).Socioeconomic security for a better World.Geneva: ILO.

Jodha, N. S. (1988). Poverty Debate in India: A Minority View. Economic and Political Weekly, 23(45/47), 2421-2428.

Kingdon, G. G., \& Knight, J. (2006).Subjective well-being poverty vs. Income poverty and capabilities poverty?The Journal of Development Studies, 42(7), 1199-1224.

Layard, R. (2005). Happiness: lessons from a new science Penguin, London, UK. ISBN 9780141016900

Lever, J. P. (2004).Poverty and Subjective Well-being in Mexico. Social Indicators Research, 68(1), 1-33.

Mangahas, M. (1995). Self-rated poverty in the Phillippines, 1981-1992. International Journal of Public Opinion Research, 7(1), 40-52.

Michalos, A. C. (2008). Education, Happiness and Wellbeing. Social Indicators Research, 87(3), $347-366$.

Oishi, S., \& Kesebir, S. (2015). Income inequality explains why economic growth does not always translate to an increase in happiness. Psychological science, 26(10), 1630-1638.

Pradhan, M., \& Ravallion, M. (2000). Measuring Poverty Using Qualitative Perceptions of Consumption Adequacy. The Review of Economics and Statistics, 82(3), 462-471.

Ravallion, M., \& Lokshin, M. (2002). Self-rated economic welfare in Russia. European Economic Review, 46(8), 1453-1473.

Riffault H. (1991) How Poverty is Perceived. In: Reif K., Inglehart R. (eds) Eurobarometer. Palgrave Macmillan, London

Ross, C. E., \& Van Willigen, M. (1997). Education and the subjective quality of life. Journal of health and social behavior, Vol. 38, No. 3, 275-297.

Sen, A. (1988). The Standard of Living. Cambridge University Press

Sen, A. (1993). Capability and Well-being. The quality of life, 30, Oxford: Clarendon Press.

Shams, K. (2014). Determinants of Subjective Well-Being and Poverty in Rural Pakistan: A Micro-Level Study. Social Indicators Research, 119(3), 1755-1773. 
Stevenson, B., \& Wolfers, J. (2013). Subjective well-being and income: Is there any evidence of satiation? The American Economic Review, 103(3), 598-604.

Van Praag, B. M. S. (1971). The Welfare Function of Income in Belgium: An Empirical Investigation. European Economic Review. 2(3): 337-69, doi:10.1016/00142921(71)90045-6

Van Praag, B. M. (1968). Individual welfare functions and consumer behavior: A theory of rational irrationality, Vol. 57. North-Holland Pub. Co..

Van Praag, B. M. S., Frijters, P., \& Ferrer-i-Carbonell, A. (2003).The anatomy of subjective well-being.Journal of Economic Behavior \& Organization, 51(1), 29-49.

Vos, K. D., \& Garner, T. I.(1991). An Evaluation of Subjective Poverty Definitions: Comparing Results from the U.S. and the Netherlands. Review of Income and Wealth, 37(3): 267-85.

Warr, P. (1999). Well-Being and the Workplace. In D. Kahneman, E. Diener, \& N. Schwarz (Eds.), Well-Being: The Foundations of Hedonic Psychology (pp. 392-412). New York: Russell Sage Foundation.

Winkelmann, R. (2005). Subjective well-being and the family: Results from an ordered probit model with multiple random effects. Empirical Economics, 30(3), 749-761.

Zhou, S., \& Yu, X. (2017). Regional Heterogeneity of Life Satisfaction in Urban China: Evidence from Hierarchical Ordered Logit Analysis. Social Indicators Research, 132(1), $25-45$. 


\section{Appendix}

Figure 2. 1 Relationship between per capita expenditure and subjective well-being

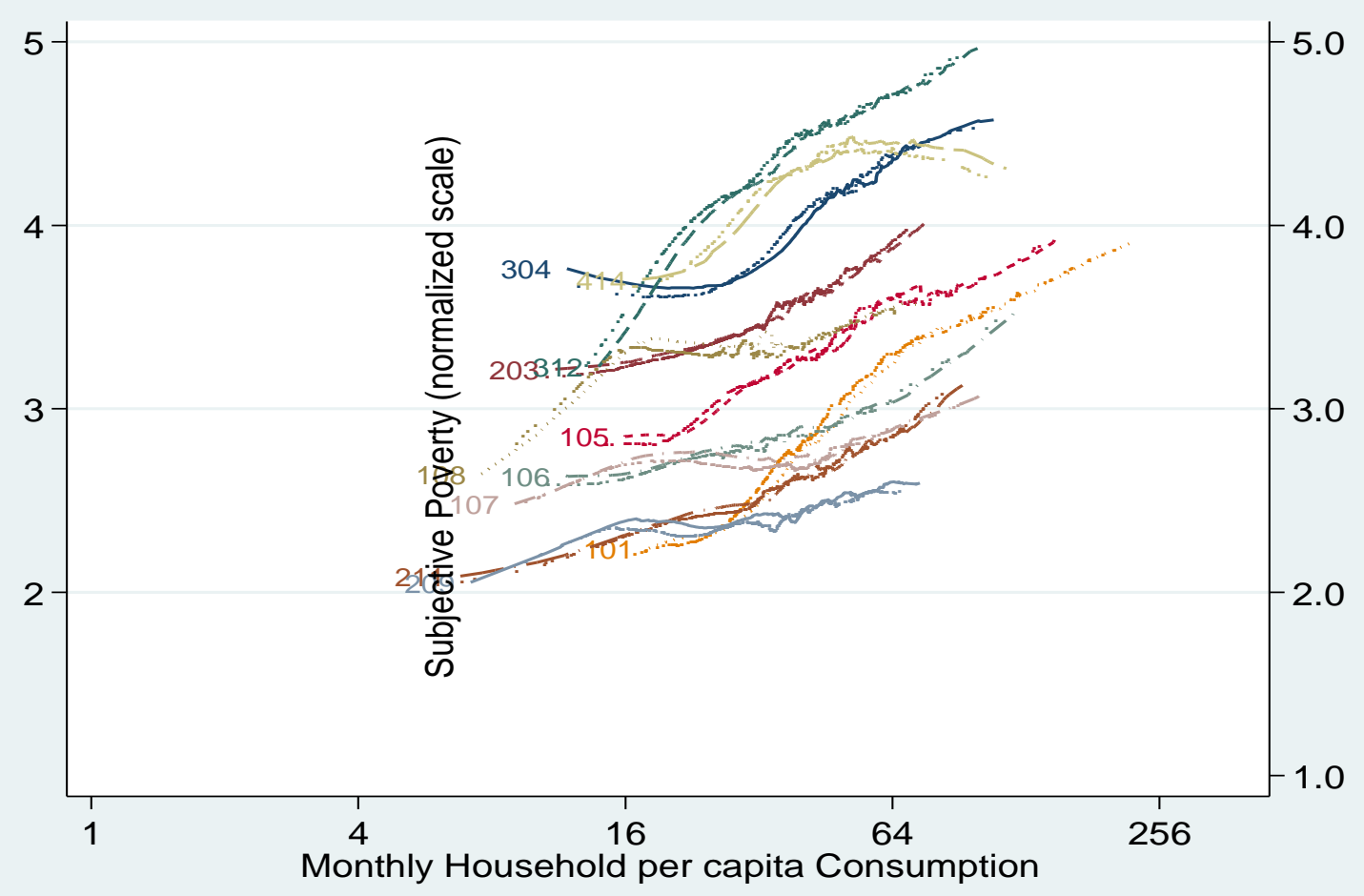


Do the Poor really Feel Poor? Comparing Objective Poverty with...

Appendix Table 1 Weighting scheme of sample households

\begin{tabular}{|c|c|c|c|c|c|c|}
\hline Districts & $\begin{array}{l}\text { Total } \\
\text { population }^{\mathrm{a}}\end{array}$ & $\begin{array}{l}\text { Sample } \\
\text { population }^{\text {b }}\end{array}$ & $\begin{array}{l}\text { pweights } \\
{\left[(T P)_{j} /(S P)_{j}\right]}\end{array}$ & $\begin{array}{l}\text { pw-normalized } \\
{\left[(P W)_{J} / \sum(P W)_{j}\right]}\end{array}$ & $\begin{array}{l}\text { pw-normalized- } \\
\text { Urban } \\
{\left[(P W u)_{J} \sum(P W u)_{j}\right]}\end{array}$ & $\begin{array}{l}\text { pw-normalized- } \\
\text { Rural } \\
{\left[(P W r)_{J} / \sum(P W r)_{j}\right]}\end{array}$ \\
\hline & $(T P)_{j}$ & $(S P)_{j}$ & $(P W)_{J}$ & $(P W N)_{J}$ & $(P W N u)_{J}$ & $(P W N r)_{J}$ \\
\hline Faisalabad & 5429547 & 3031 & 1791.33 & 0.207 & 0.166 & 0.172 \\
\hline Attock & 1274935 & 1344 & 948.61 & 0.093 & 0.083 & 0.081 \\
\hline Hafizabad & 1136044 & 3648 & 311.41 & 0.049 & 0.041 & 0.023 \\
\hline Vehari & 717649 & 2563 & 280.00 & 0.045 & 0.034 & 0.021 \\
\hline Muzafargarh & 832980 & 1785 & 466.65 & 0.038 & 0.055 & 0.035 \\
\hline Bahawalpur & 2090416 & 1895 & 1103.12 & 0.090 & 0.074 & 0.097 \\
\hline Badin & 2635903 & 1972 & 1336.66 & 0.055 & 0.082 & 0.117 \\
\hline Nawabshah & 2433091 & 2406 & 1011.26 & 0.079 & 0.113 & 0.078 \\
\hline MirpurKhas & 1071533 & 2237 & 479.00 & 0.049 & 0.054 & 0.036 \\
\hline Larkana & 905935 & 1603 & 565.14 & 0.029 & 0.060 & 0.045 \\
\hline Dir & 1927066 & 2545 & 757.19 & 0.093 & 0.069 & 0.065 \\
\hline Mardan & 1460100 & 1872 & 779.96 & 0.063 & 0.049 & 0.075 \\
\hline LakkiMarwat & 490025 & 543 & 902.44 & 0.047 & 0.032 & 0.090 \\
\hline loralai & 297554 & 1409 & 211.18 & 0.019 & 0.010 & 0.019 \\
\hline Kuzdar & 417466 & 937 & 445.53 & 0.026 & 0.045 & 0.035 \\
\hline Gwadar & 185498 & 1220 & 152.04 & 0.010 & 0.026 & 0.008 \\
\hline Total & 23305743 & 31010 & 11541.59 & 1 & 1 & 1 \\
\hline
\end{tabular}

$\mathrm{a}=$ Census 1998, $\mathrm{b}=$ Pakistan Panel Household Survey (PPHS) 2010. Author calculation 
Do the Poor really Feel Poor? Comparing Objective Poverty with...

Appendix Table 2 Comparison of subjective poverty and objective poverty (\$1)

\begin{tabular}{|c|c|c|c|c|c|c|}
\hline \multirow[b]{3}{*}{ Variables } & \multicolumn{3}{|c|}{ Model $1^{a}$} & \multicolumn{3}{|c|}{ Model $1^{b}$} \\
\hline & Category 2 & Category 3 & Category 4 & Category 2 & Category 3 & Category 4 \\
\hline & $\begin{array}{l}\text { Objective } \\
\text { poor }\end{array}$ & $\begin{array}{l}\text { Subjective } \\
\text { poor }\end{array}$ & Overall poor & Objective poor & $\begin{array}{l}\text { Subjective } \\
\text { poor }\end{array}$ & Overall poor \\
\hline \multicolumn{7}{|c|}{ Household size as a continuous variable } \\
\hline \multirow[t]{2}{*}{ Householdsize } & $0.195^{* * *}$ & $-0.094 * * *$ & $0.127^{* * *}$ & $0.167^{* * *}$ & $-0.102 * * *$ & $0.125^{* * *}$ \\
\hline & $(0.021)$ & $(0.032)$ & $(0.024)$ & $(0.019)$ & $(0.030)$ & $(0.023)$ \\
\hline \multicolumn{7}{|c|}{ Gender classification } \\
\hline \multirow[t]{2}{*}{ Girls $<18$ years } & -0.037 & -0.007 & -0.021 & & & \\
\hline & $(0.032)$ & $(0.038)$ & $(0.040)$ & & & \\
\hline \multirow[t]{2}{*}{ Boys $<18$ years } & $-0.092 * * *$ & -0.029 & $-0.068 *$ & & & \\
\hline & $(0.032)$ & $(0.041)$ & $(0.039)$ & & & \\
\hline \multirow[t]{2}{*}{ Girls $<6$ years } & & & & -0.032 & 0.0205 & -0.044 \\
\hline & & & & $(0.054)$ & $(0.066)$ & $(0.070)$ \\
\hline \multirow[t]{2}{*}{ Boys $<6$ years } & & & & -0.056 & -0.040 & $-0.172 * *$ \\
\hline & & & & $(0.056)$ & $(0.069)$ & $(0.070)$ \\
\hline \multicolumn{7}{|c|}{ Age of household head } \\
\hline \multirow[t]{2}{*}{ age } & 0.006 & 0.029 & 0.003 & 0.001 & 0.028 & -0.005 \\
\hline & $(0.018)$ & $(0.021)$ & $(0.019)$ & $(0.014)$ & $(0.021)$ & $(0.019)$ \\
\hline \multirow[t]{2}{*}{ Age squared } & -0.0001 & -0.0002 & -0.0001 & -0.0001 & -0.0003 & $-5.09 e-05$ \\
\hline & $(0.0001)$ & $(0.0002)$ & $(0.0002)$ & $(0.0001)$ & $(0.0002)$ & $(0.0001)$ \\
\hline \multicolumn{7}{|c|}{ Household head education (years of schooling as a continuous variable) } \\
\hline \multirow[t]{2}{*}{ Schooling } & $-0.074 * * *$ & $-0.050 * * *$ & $-0.093 * * *$ & $-0.072 * * *$ & $-0.0495^{* * *}$ & $-0.092 * * *$ \\
\hline & $(0.011)$ & $(0.012)$ & $(0.012)$ & $(0.010)$ & $(0.0119)$ & $(0.012)$ \\
\hline \multicolumn{7}{|c|}{ Marital status (Reference category married) } \\
\hline \multirow[t]{2}{*}{ Divorced } & 0.172 & 0.245 & 0.007 & 0.176 & 0.242 & 0.011 \\
\hline & $(0.205)$ & $(0.226)$ & $(0.214)$ & $(0.208)$ & $(0.225)$ & $(0.214)$ \\
\hline \multirow[t]{2}{*}{ Single } & -0.238 & -0.548 & 0.330 & -0.176 & -0.521 & 0.275 \\
\hline & $(0.348)$ & $(0.390)$ & $(0.376)$ & $(0.349)$ & (0.389) & $(0.374)$ \\
\hline \multicolumn{7}{|c|}{ Employment status (Reference category unemployed) } \\
\hline \multirow[t]{2}{*}{ Employed } & 0.0257 & 0.041 & $-0.355^{* *}$ & -0.021 & 0.0247 & $-0.395^{* *}$ \\
\hline & $(0.158)$ & $(0.166)$ & $(0.163)$ & $(0.158)$ & $(0.165)$ & $(0.162)$ \\
\hline \multicolumn{7}{|c|}{ Own business (Reference category No) } \\
\hline \multirow[t]{2}{*}{ Yes } & $-0.376 * *$ & $-0.306^{*}$ & $-0.427^{* *}$ & $-0.359 * *$ & $-0.305^{*}$ & $-0.423 * *$ \\
\hline & $(0.162)$ & $(0.175)$ & $(0.203)$ & $(0.162)$ & $(0.174)$ & $(0.204)$ \\
\hline \multicolumn{7}{|c|}{ Agriculture land (Reference category No) } \\
\hline \multirow[t]{2}{*}{ Yes } & -0.016 & -0.101 & 0.016 & -0.017 & -0.106 & 0.014 \\
\hline & $(0.125)$ & $(0.146)$ & $(0.153)$ & $(0.125)$ & $(0.146)$ & $(0.153)$ \\
\hline Farmer (Referenc & category No & & & & & \\
\hline Yes & 0.064 & -0.079 & $0.315^{*}$ & 0.083 & -0.073 & $0.319 *$ \\
\hline & $(0.163)$ & $(0.182)$ & $(0.180)$ & $(0.162)$ & $(0.182)$ & $(0.180)$ \\
\hline Interaction term & armer and aq & |ture land) & & & & \\
\hline Interaction term & -0.108 & -0.183 & $-0.462 *$ & -0.101 & -0.179 & $-0.447^{*}$ \\
\hline & $(0.205)$ & $(0.241)$ & $(0.236)$ & $(0.204)$ & $(0.241)$ & $(0.235)$ \\
\hline
\end{tabular}


Do the Poor really Feel Poor? Comparing Objective Poverty with...

\begin{tabular}{|c|c|c|c|c|c|c|}
\hline \multicolumn{7}{|c|}{ Own house (Reference category No) } \\
\hline \multirow[t]{2}{*}{ Yes } & $-0.334 * * *$ & $-0.527 * * *$ & $-0.810 * * *$ & $-0.334 * * *$ & $-0.530 * * *$ & $-0.822 * * *$ \\
\hline & $(0.113)$ & $(0.125)$ & $(0.135)$ & $(0.112)$ & $(0.125)$ & $(0.135)$ \\
\hline \multicolumn{7}{|c|}{ Livestock (Reference category No) } \\
\hline \multirow[t]{2}{*}{ Yes } & -0.048 & 0.154 & $-0.322 * *$ & -0.042 & 0.156 & $-0.304^{*}$ \\
\hline & $(0.138)$ & $(0.172)$ & $(0.161)$ & $(0.139)$ & $(0.172)$ & $(0.161)$ \\
\hline \multicolumn{7}{|c|}{ Borrowing (Reference category No) } \\
\hline \multirow[t]{2}{*}{ Yes } & -0.039 & -0.018 & 0.090 & -0.036 & -0.020 & 0.097 \\
\hline & $(0.108)$ & $(0.113)$ & $(0.118)$ & $(0.108)$ & $(0.113)$ & $(0.118)$ \\
\hline \multicolumn{7}{|c|}{ Household asset (television) (Reference category No) } \\
\hline \multirow[t]{2}{*}{ Yes } & $-0.666 * * *$ & $-0.227^{*}$ & $-0.520 * * *$ & $-0.660 * * *$ & $-0.226^{*}$ & $-0.525 * * *$ \\
\hline & $(0.101)$ & $(0.118)$ & $(0.123)$ & $(0.101)$ & $(0.118)$ & $(0.123)$ \\
\hline \multicolumn{7}{|c|}{ Food insecurity (Reference category secure) } \\
\hline \multirow[t]{2}{*}{ Food insecure } & 0.087 & $0.273^{* *}$ & $0.569 * * *$ & 0.077 & $0.270 * *$ & $0.566 * * *$ \\
\hline & $(0.101)$ & $(0.119)$ & $(0.125)$ & $(0.101)$ & $(0.119)$ & $(0.125)$ \\
\hline \multicolumn{7}{|c|}{ Physical injury (Reference category No injury) } \\
\hline \multirow[t]{2}{*}{ injury } & 0.079 & $0.212^{*}$ & $0.242 * *$ & 0.068 & $0.211 *$ & $0.241 *$ \\
\hline & $(0.112)$ & $(0.126)$ & $(0.123)$ & $(0.112)$ & $(0.125)$ & $(0.124)$ \\
\hline \multicolumn{7}{|c|}{ Water facility (Reference category unimproved) } \\
\hline \multirow[t]{2}{*}{ Improved } & -0.044 & -0.022 & -0.229 & -0.0582 & -0.0280 & -0.237 \\
\hline & $(0.150)$ & $(0.190)$ & $(0.177)$ & $(0.149)$ & $(0.190)$ & $(0.177)$ \\
\hline \multicolumn{7}{|c|}{ Sanitation facility (Reference category unimproved) } \\
\hline \multirow[t]{2}{*}{ Improved } & $-0.357 * * *$ & -0.168 & $-0.475 * * *$ & $-0.346 * * *$ & -0.165 & $-0.476 * * *$ \\
\hline & $(0.097)$ & $(0.119)$ & $(0.113)$ & $(0.097)$ & $(0.119)$ & $(0.112)$ \\
\hline \multicolumn{7}{|c|}{ Provinces (Reference category Punjab) } \\
\hline \multirow[t]{2}{*}{ Sindh } & -0.018 & $0.298^{* *}$ & 0.190 & -0.045 & $0.287 * *$ & 0.191 \\
\hline & $(0.108)$ & $(0.119)$ & $(0.124)$ & $(0.108)$ & $(0.118)$ & $(0.124)$ \\
\hline \multirow[t]{2}{*}{ KP } & -0.173 & $-0.802 * * *$ & $-1.002 * * *$ & -0.175 & $-0.806 * * *$ & $-1.044^{* * *}$ \\
\hline & $(0.129)$ & $(0.161)$ & $(0.181)$ & $(0.129)$ & $(0.160)$ & $(0.181)$ \\
\hline \multirow[t]{2}{*}{ Baluchistan } & $-0.502 * * *$ & $-1.725 * * *$ & $-1.925^{* * *}$ & $-0.537 * * *$ & $-1.739 * * *$ & $-1.956 * * *$ \\
\hline & $(0.154)$ & $(0.248)$ & $(0.333)$ & $(0.155)$ & $(0.248)$ & $(0.332)$ \\
\hline \multicolumn{7}{|c|}{ Region (Reference category rural) } \\
\hline \multirow[t]{2}{*}{ Urban } & 0.0217 & $0.277^{* *}$ & 0.204 & 0.0179 & $0.273 * *$ & 0.189 \\
\hline & $(0.123)$ & $(0.132)$ & $(0.148)$ & $(0.123)$ & $(0.132)$ & $(0.148)$ \\
\hline \multirow[t]{2}{*}{ Constant } & -0.321 & -0.184 & 0.296 & -0.193 & -0.165 & 0.573 \\
\hline & $(0.507)$ & $(0.555)$ & $(0.545)$ & $(0.518)$ & $(0.567)$ & $(0.553)$ \\
\hline \multicolumn{7}{|l|}{ Diagnostic test } \\
\hline Wald chi2(75) & 722.18 & & & 716.73 & & \\
\hline Prob > chi2 & 0.000 & & & 0.000 & & \\
\hline $\begin{array}{l}\text { Log } \\
\text { pseudolikelihood }\end{array}$ & -206.578 & & & -206.733 & & \\
\hline Number of obs. & 3015 & & & 3015 & & \\
\hline
\end{tabular}

Robust standarderrors in parentheses; *** $p<0.01$, ** $p<0.05, * p<0.1$

$a=$ Model 1: Multinomial model based on gender classification less than 18 years

$b=$ Model 2: Multinomial model based on gender classification less than 6 years 


\section{Chapter 3 He Said, She Said: Unpacking Pakistan's Intra-household Gender Differences in Subjective Well-being}

\subsection{Introduction}

In recent years, researchers have made increasing use of subjective measures of well-being. For instance life satisfaction and happiness (Stevenson and Woofers 2013; Kingdon and Knight 2006; Zhou and Yu 2017; Deeming 2013; Shams 2014) or economic position (Mangahas 1995; Riffault 1991; Ravallion and Lokshin 2002). ${ }^{14}$ This extensive literature has help to herald a global emerging consensus on subjective measures of well-being. Similarly, numerous researches explore gender differences in welfare economics and their implications for economic development. We use a new procedure to estimates gender differences within households by comparing affirmative response about economic position of female-male couples. This gives evidence on how well the subjective well-being of couple is jointly distributed within households. Given that both members within the household are assessing the same question, it is reasonable to envisage if that their affirmative responses about subjective economic position differ then it would cause gender differences in subjective well-being in relative terms. This can be investigated by examining the factors affecting the difference in couple's answers, controlling for other possible influence on relative economic situation.

The economics of happiness literature reveals that women well-being is generally higher than men. However, these studies are available mainly for developed countries (Zweig 2015; Helliwell et al. 2015; Stevenson and Wolfer 2009; Blanchflower and Oswald 2004; Dolan et al. 2008; Easterlin 2001; Frey and Stutzer 2002). Nevertheless, differences in subjective well-being disappear after controlling for demographic and household characteristics (Diener et al. 1999; Veira Lima 2011). Furthermore, Stevensen and Wolfers (2009) find that women happiness decline in relative term over the last 30 years in most western countries, despite objective improvement in their economic position as well as bargaining power. Similarly, the psychology studies are in complete consonance with happiness studies that women well-being are higher

\footnotetext{
${ }^{14}$ Subjective well-being is defined as “a person's cognitive and affective evaluations of his or her life' (Diener et al. 2002). We have broader concept of subjective well-being (life satisfaction, happiness) and narrow definition of subjective well-being (perception about economic situation). In this study, we use the narrow definition of subjective well-being.
} 
than men, however, depression and anxiety are common in women (Nolen-Hoeksema and Rusting 2003).

Similarly, the female-male happiness gap is less clear in transition and developing countries. ${ }^{15}$ Specifically, in China rural women are happier than rural men after controlling for both objective and subjective household characteristics (Knight et al. 2009). Furthermore, Jovanovic (2017) study reveals that women are happier than men for the case of Iran. In contrast, Senik (2004) finding asserts that men are happier than women in Russia. In addition, there are no happiness differences between women and men for 15 Latin American nations (Graham and Pettinato 2001). Graham and Chattopadhyay (2012) findings show that women well-being are higher in high income countries, while there is no significant difference observed in lower income countries.

Only a few studies use subjective economic position directly to analyze intra-household gender differences in subjective well-being. Kalugina et al. (2009) used Russian data to estimate spouses' relative shares by the difference in how they positioned themselves on societal poorrich ladders, which they found that spousal wage differences are the main cause of difference in well-being. Similarly, Bonke and Browing (2009) utilized cross sectional Danish data that interpret answers to a question on satisfaction with regard to present financial situation indicating respondents' level of material well-being in general and their consumption in particular. The findings confirm differences in a couples' subjective well-being among other factors on their relative employment statuses and nonlinearity on their income shares. In addition Alessie et al. (2006) using the same subjective economic position question find that female relative share of income has a significant influence on female consumption shares in the majority of the European Union countries. Moreover, gender differences have also been analyzed with regard to satisfaction and marriage (Ross 1991) and satisfaction in life with divorce (Andress and Brockel 2007).

The gender aspect here is that contributions are unequally distributed by gender in general (men on average devote more time to paid work and women to housework and childcare).That is men's employment has been found to be more desirable than women's (Mies 1982). Similarly, Bennett et al. (2012) study shows that men and women have different perceptions about the relative contributions that are, women are more aware of the tension between supposedly joint

\footnotetext{
${ }^{15}$ In happiness literature, the term life satisfaction, happiness, and subjective well-being are used interchangeably.
} 
and individual interests. In addition; perception of well-being may vary with the distribution of resources within the household. Thus, for example a female breadwinner respondent may feel worse off because of her breadwinner partner does not want to share his non-poor income with her.

In the first place the human development concept derived from the fact that income or consumption is not a direct measure of life quality and other factors such as health, education, gender equity, and so on can be valuable (Sen 1985). Furthermore, objective measure of wellbeing is necessary but not sufficient because of heterogeneity that people react differently to the same events (Diner and Lucas 1999). Unlike expenditure data collected at the household level, one advantage of using individuals answers such as those about satisfaction or economic position is that they can unquestionably be assigned to each partner. The benefit of this narrowed definition is that it makes the comparison to a monetary measure of well-being more meaningful. Another advantage of perception type variable unlike orthodox and/or physical variables, they do not require extensive cleaning of the data and less costly. Generally, the perception type surveys are easy to answers. Unlike official objective measures, the subjective measure of well-being is not easily prone to manipulation. The subjective well-being, nevertheless also confronts with some issues such as response errors, random discrepancies in the interpretation of the surveys questions, idiosyncratic differences in the respondents' moods and differences in preferences (taste and personality). However, for specific purposes such as welfare impacts of policies and overall well-being, one would not attach considerable significance to such differences.

Importantly research on gender differences' in subjective well-being is actually not available for Pakistan, while Pakistan is an emerging middle income and populous country. In recent years, Pakistan has experienced a relatively rapid economic growth. Hence, the motivation of the study is to fill the existing research gap. First, explore the determinants of couple's subjective wellbeing within households. Second, unpack the factors that cause intra-household gender differences. To this end, the following question is asked from male-female respondents within households: "In our society some people have higher economic position, and other has lower economic position. Below is a scale from one to ten. The numbers 1 through 10 represent different levels of economic position, from the lowest to the highest. On the scale, please indicate 
the position you occupy". ${ }^{16}$ Accordingly, the research question/hypothesis of the study; whether there exists gender difference in subjective measure of well-being. If so, what are the factors that lead to such gender gap in well-being?

The rest of the paper is organized as follows. Section 2 explains the data design, hypothesis, variables and shows descriptive statistics. Section 3 presents the empirical method, followed by empirical results and discussions in section 4. Finally, section 5 concludes and gives some implications.

\subsection{Data, hypothesis and variables}

\subsubsection{Research design and hypothesis}

Our analysis is based on the third round Pakistan Panel Household Survey (PPHS) 2010, a joint project of the Pakistan Institute of Development Economics (PIDE) and the World Bank. The sample size is 4142 households covering four provinces of which 2800 are rural and 1342 urban households. After cleaning the data with missing variables, we obtained 2696 households consisting of 1938 rural and 758 urban samples. The PPHS covers a wide range of issues such as fertility, education, employment, health, nutrition, food insecurity, housing, and well-being. The current study utilizes cross sectional data. The cross sectional survey data is easier and cheaper than the longitudinal data, no follow up is required and have greater control over precision of estimates in subgroups particularly due to stratified sampling. The disadvantage of using surveys data are no control over purpose and method of data collection in case of secondary data. In addition, cannot say much about causality but only correlation

In this paper we test the main drivers of gender differences in subjective well-being. We also test the hypotheses, first, are there any significant differences in couple's subjective well-being? This hypothesis will be tested by t-test using the mean value of couple's subjective well-being. Second, what are the main drivers that lead to gender differences in subjective well-being?

\subsubsection{Variables and Descriptive statistics}

\subsubsection{Outcome variables}

The basic subjective question, which is asked from the male and female respondents within household that ranks the households from the lowest ladder (1) to the highest ladder (10) in terms

\footnotetext{
${ }^{16}$ : This question is asked from male and female within household. The data used in the analysis is only confined to husband-wife respondents to avoid ambiguity.
} 
of economic position. Hence the outcome variables are the male and female subjective wellbeing and the gender differences of subjective well-being. The gender difference variable is generated (female-male subjective well-being) by taking the difference of response of female and male subjective well-being. The generated outcome variable is a continuous variable which range from -7 to +8 . The lowest value -7 indicates that the subjective well-being of male (female) is the highest (lowest) while the highest (lowest) value shows that the subjective wellbeing of male (female) is the lowest (highest). (see Figure 3.1). Third we generated three nominal categories such as category-0 is neutral (same subjective well-being within household), category- 1 is where male subjective well-being is high and category- 2 is where female subjective well-being is high. ${ }^{17}$

\section{Figure 3.1 Gender differences in subjective well-being}

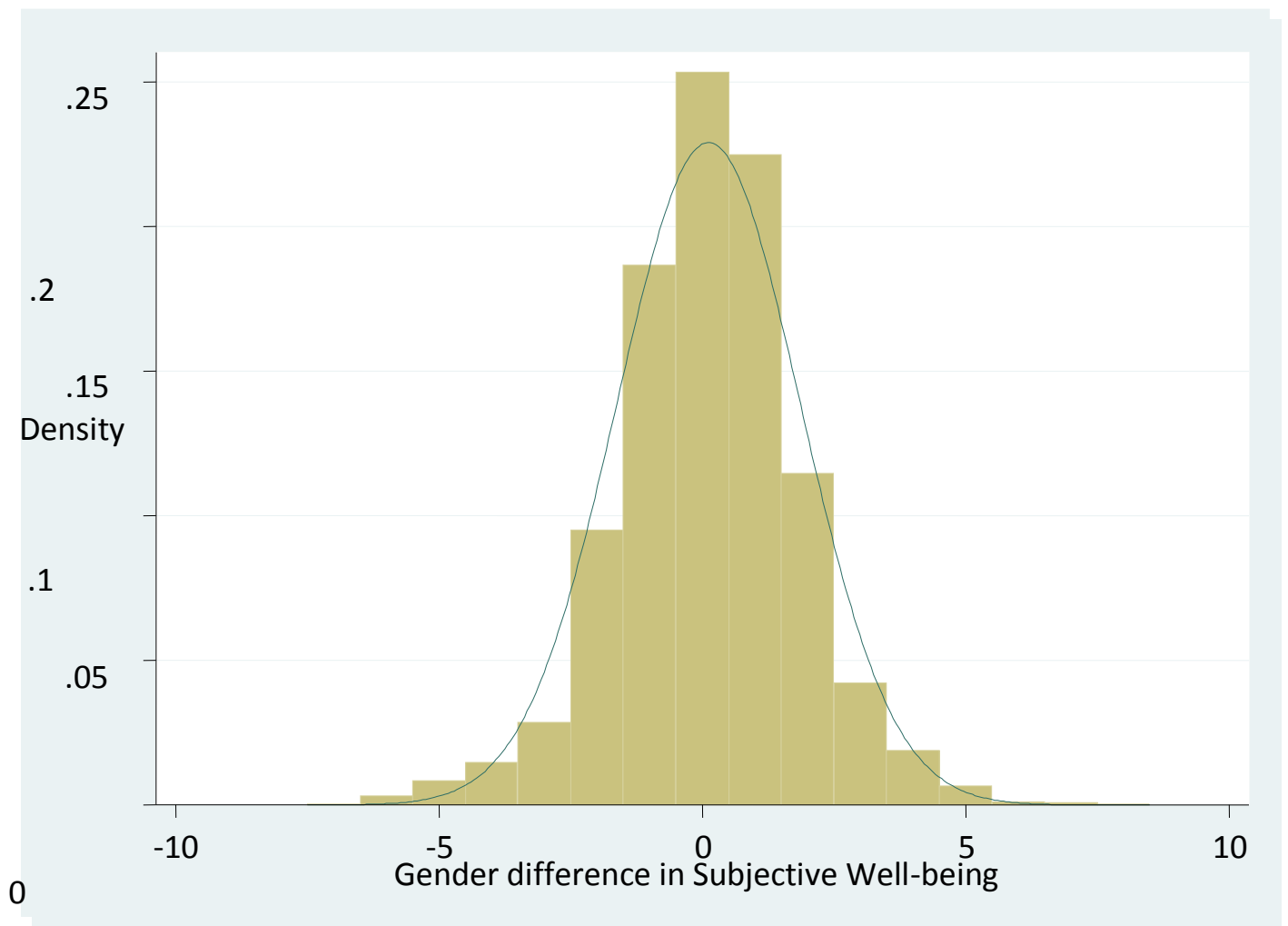

\subsubsection{Explanatory variables}

The explanatory variables that determine the subjective well-being included in the analysis are: (1) Per capita consumption; (2) Household size; (3) Gender based classification of children less than 18 years and also less than 6 years; (4) Age, education, marital status and employment

\footnotetext{
${ }^{17}$ All the continuous variables with negative sign are considered as category-1, while all the value with positive sign are considered as category- 2 , and value zero is considered as category- 0 .
} 
status of both male and female respondents within household; (5) Household characteristics, which are expected to affect the subjective well-being such as household assets proxies by television, agriculture land holding, water and sanitation facilities, and livestock. Presumably any or all of these variables can have different effects on subjective well-being of each respondent. In addition, two important variables food vulnerability and physical insecurity are included that are often missing due to difficulties in measurement (Sen 1988). For instance, Alkire (2007) stressed that insufficient empirical data which has a direct impact on the human development and well-being particularly on the poor such as physical security, agency, and empowerment, could improve standard surveys in a promising way. To check if these variables affect well-being and policy, we take into account physical insecurity measured by community insecurity and food insecurity in the analysis. The community insecurity question might have strong expected negative impact on well-being and policy relevance, because terrorism was at its peak in Pakistan in 2010. Clearly, the food insecurity question also could have a strong adverse impact on the well-being, due to a bad harvest and flood in 2010, which almost destroyed fifty percent of the crops yield. Moreover, to control for regional heterogeneities regional and provincial dummies are utilized in the analysis.

Similarly, the interaction term between household asset and per capita consumption has expected positive impact on subjective well-being. The interaction term with income or consumption makes strong assumption of being well off. Hence, we expect a significant positive impact of interaction term on the subjective well-being. Table 3.1 describes the definition of variables.

\section{Table 3.1 Definition of variables}

\begin{tabular}{|c|c|}
\hline Variables & Definitions \\
\hline Outcome variables & \\
\hline $\begin{array}{l}\text { Subjective Well-being, }(1-10) \\
\text { Both male and female } \\
\text { respondent of household }\end{array}$ & $\begin{array}{l}\text { In our society, some people have high economic position (rich), and } \\
\text { other have low economic position (poor). Below is a scale from one } \\
\text { to ten. The numbers } 1 \text { through } 10 \text { represent different levels in terms } \\
\text { of economic position, from the lowest to the highest. On the scale, } \\
\text { please indicate the position you occupy. }\end{array}$ \\
\hline $\begin{array}{l}\text { Difference of female \& male } \\
\text { subjective well-being }\end{array}$ & $\begin{array}{l}\text { We have gender difference of } 10 \text { scale ladder by subtracting the } \\
\text { subjective well-being of female from male subjective well-being }\end{array}$ \\
\hline $\begin{array}{l}\text { Comparison } \quad \text { (Three } \\
\text { categories) }\end{array}$ & $\begin{array}{l}\text { We have generated three categories from the gender difference } \\
\text { values: Category- } 1=\text { Household with same subjective well-being, } \\
\text { category- } 2=\text { Male subjective well-being is higher, category- } 3= \\
\text { Female subjective well-being is higher }\end{array}$ \\
\hline
\end{tabular}

Log of per capita Household natural log of per capita consumption used as proxy for 


\begin{tabular}{|c|c|}
\hline Variables & Definitions \\
\hline consumption & household per capita income. \\
\hline Household size & Total member of the household as a continuous variable \\
\hline $\begin{array}{l}\text { Gender based classification of } \\
\text { children less than } 18 \text { years \& } \\
6 \text { years age }\end{array}$ & $\begin{array}{l}\text { We have constructed continuous variables of children male and } \\
\text { female separately as an explanatory variable. To examine how the } \\
\text { gender of child affects subjective well-being }\end{array}$ \\
\hline Age of both respondents & Included both age and age-squared \\
\hline $\begin{array}{l}\text { Education of both } \\
\text { respondents }\end{array}$ & We have used education as years of schooling as continuous variable. \\
\hline $\begin{array}{l}\text { Respondent employment } \\
\text { level }\end{array}$ & $\begin{array}{l}\text { We categorize employment status of each respondents into whether } \\
\text { household head is employed, or not Yes }=1, \text { No }=0\end{array}$ \\
\hline Agriculture land & Did the household own agriculture land? Yes $=1$, No $=0$ \\
\hline livestock & $\begin{array}{l}\text { Does your household currently own animals? } \\
\text { Yes }=1, \text { No }=0\end{array}$ \\
\hline Food vulnerability & $\begin{array}{l}\text { During the last } 12 \text { months was your household worried any time that } \\
\text { your food would run out before you had money to buy more? } \\
\text { Yes }=1, \text { No }=0\end{array}$ \\
\hline Community insecurity level & $\begin{array}{l}\text { In the last } 12 \text { months, have you heard any incidents or injury or } \\
\text { property damage experienced by others living in your community? } \\
\text { Yes }=1, \text { No }=0\end{array}$ \\
\hline Water facility & $\begin{array}{l}\text { World health organization definition of improved drinking water } \\
\text { definition } \\
\text { Improved }=1, \text { No }=0\end{array}$ \\
\hline Sanitation facility & $\begin{array}{l}\text { WHO definition of improved sanitation facility } \\
\text { Improved }=1, \text { No }=0\end{array}$ \\
\hline Residence own & $\begin{array}{l}\text { Whether household has its own house? } \\
\text { Yes }=1, \text { No }=0\end{array}$ \\
\hline Household asset (television) & $\begin{array}{l}\text { Household having television in their houses as an asset } \\
\text { Yes }=1, \text { No }=0\end{array}$ \\
\hline $\begin{array}{l}\text { Interaction term per capita } \\
\text { consumption plus asset }\end{array}$ & We use interaction between asset and consumption \\
\hline Region & We have two region, Urban $=1$, Rural $=0$ \\
\hline Provinces & $\begin{array}{l}\text { Province }-1=\text { Punjab, province }-2=\text { Sindh, province }-3=K P \text {, province- } \\
4=\text { Baluchistan }\end{array}$ \\
\hline
\end{tabular}

\subsubsection{Descriptive statistics}

Table 3.2 shows the descriptive statistics of demographic and socio-economic characteristics of the households under study. Almost $50 \%$ of the men and $86 \%$ of the female are illiterate. Average age of the male is 47 and for female, it is 41 . Equivalent household size is calculated according to the modified OECD equivalence scale. The average household size is 5.36 which is slightly less than the average household size 6.41 (Household Integrated Economic Survey 2011-2012) and national average household size 6.38 members observed for the period 20102011. Similarly, $40 \%$ of the households have agriculture land holding, only $11 \%$ livestock holding, and approximately $50 \%$ possess assets. In addition, $79 \%$ of the households have their 
own residence, and approximately half of the households have no sanitation facilities. Alarmingly, $58 \%$ of the households are food insecure and $22 \%$ faced physical insecurity. Almost $28 \%$ of the households live in urban area. Moreover, the distributions of households are 33, 36, 16, and $15 \%$ for Punjab, Sindh, KP and Baluchistan, respectively.

Table 3.2 Demographic and socio-economic characteristics of household

\begin{tabular}{|c|c|c|c|c|}
\hline Characteristics & Mean & Std. dev. & Min & Max \\
\hline \multicolumn{5}{|l|}{ Outcome Variables } \\
\hline Subjective well-being (male) & 3.357 & 1.450 & 1 & 10 \\
\hline Subjective well-being (female) & 3.475 & 1.584 & 1 & 10 \\
\hline Gender difference (female - male) & 0.117 & 1.741 & -7 & 8 \\
\hline \multicolumn{5}{|l|}{ Male characteristics } \\
\hline Age & 47.319 & 14.300 & 19 & 90 \\
\hline Schooling & 3.937 & 4.782 & 0 & 15 \\
\hline Employment & 0.847 & 0.359 & $0=\mathrm{No}$ & $1=$ Yes \\
\hline \multicolumn{5}{|l|}{ Female characteristics } \\
\hline Age & 41.302 & 13.111 & 16 & 83 \\
\hline Schooling & 0.956 & 2.759 & 0 & 15 \\
\hline Employment & 0.134 & 0.340 & $0=$ No & $1=$ Yes \\
\hline \multicolumn{5}{|l|}{ Household characteristics } \\
\hline Household size & 5.361 & 2.763 & 2 & 24 \\
\hline Female children $<18$ & 1.649 & 1.522 & 0 & 12 \\
\hline Male children $<18$ & 1.800 & 1.632 & 0 & 16 \\
\hline Female children $<6$ & 0.555 & 0.846 & 0 & 5 \\
\hline Male children $<6$ & 0.575 & 0.861 & 0 & 5 \\
\hline Agriculture land holdings & 0.398 & 0.489 & $0=\mathrm{No}$ & $1=$ Yes \\
\hline Own house & 0.788 & 0.408 & $0=\mathrm{No}$ & $1=$ Yes \\
\hline Household livestock & 0.110 & 0.313 & $0=\mathrm{No}$ & $1=$ Yes \\
\hline Household asset (TV) & 0.504 & 0.500 & $0=$ No & $1=$ Yes \\
\hline Log per capita consumption & 7.752 & 0.633 & 4.98 & 11.56 \\
\hline Food insecurity & 0.576 & 0.494 & $0=\mathrm{No}$ & $1=$ Yes \\
\hline Physical injury & 0.216 & 0.412 & $0=$ No & $1=$ Yes \\
\hline Water facility & 0.9135 & 0.281 & $0=\mathrm{No}$ & $1=$ Yes \\
\hline Sanitation facility & 0.544 & 0.498 & $0=\mathrm{No}$ & $1=$ Yes \\
\hline Province & 2.136 & 1.040 & 1 & 4 \\
\hline Region & 0.281 & 0.449 & $0=$ Rural & $1=$ Urban \\
\hline
\end{tabular}

Table 3.3 shows the descriptive statistics of both male and female (couple) subjective well-being. The first part is the original question which is asked from the male respondent about his subjective well-being. The second part of the Table 3.3 is the original question which is asked from the female respondent about her subjective well-being. The couple response indicates that in general female perceive herself well off in relative terms except for Sindh province where female are worse off compared to male counterpart. The description of regional and provincial 
comparison of subjective well-being is also given. Similarly, third part of the Table 3.3 reports the male and female respondents' average subjective well-being. The average subjective economic positions of male and female are 3.36 and 3.47, respectively, which indicates that most of the couple still represent lower ladder of subjective well-being. However, women have slightly higher average level of reported economic position than men at national and regional level. This means that the average subjective well-being of female is higher than male. Our analysis also indicates significant gender differences in couple's subjective well- being. Moreover, gender difference in subjective well-being is larger in urban areas compared to rural areas. The reason could be due to women access to education, job market, and awareness due to access to electronic and social media. In addition, average level of reported economic position of women is also higher than those of men for Punjab, KP and Baluchistan provinces. However, one notable exception that is not surprising given the context is the Sindh province where the male respondents have higher average level of economic position. This could be because of Sindh province is the least developed. Importantly their women are the least educated among the provinces. Similarly, the KP province outperformed other provinces in their economic position. Importantly our results are in line with most of the previous literature where women subjective economic situation are high than men (Diener et al 1999; Veira Lima 2011; Grahman and Chattopadhyay 2012).

Table 3.3 Descriptive Statistics of Subjective Well-being in Pakistan

\begin{tabular}{lllllllllll}
\hline A. Original question rank from lowest to the highest $(\%)$ Male \\
\hline Category & 1 (lowest) & 2 & 3 & 4 & 5 & 6 & 7 & 8 & 9 & Highest \\
\hline National & 8.90 & 19.18 & 31.23 & 19.29 & 14.39 & 4.34 & 1.89 & 0.63 & 0.07 & 0.07 \\
Urban & 8.84 & 19.39 & 34.30 & 18.21 & 14.38 & 2.77 & 1.85 & 0.13 & 0.00 & 0.13 \\
Rural & 8.93 & 19.09 & 30.03 & 19.71 & 14.40 & 4.95 & 1.91 & 0.83 & 0.10 & 0.05 \\
Punjab & 8.78 & 20.27 & 40.32 & 14.53 & 11.94 & 2.93 & 1.01 & 0.23 & 0.00 & 0.00 \\
Sindh & 15.35 & 29.77 & 23.96 & 13.80 & 9.65 & 3.73 & 2.49 & 1.14 & 0.10 & 0.00 \\
KP & 2.31 & 9.70 & 18.24 & 21.25 & 33.95 & 11.32 & 3.00 & 0.23 & 0.00 & 0.00 \\
Baluchistan & 0.97 & 1.95 & 42.32 & 40.39 & 10.22 & 1.46 & 1.22 & 0.73 & 0.24 & 0.49 \\
\hline B. Original question rank from lowest to the highest $(\%)$ Female & & & & \\
\hline Category & 1 (Lowest) & 2 & 3 & 4 & 5 & 6 & 7 & 8 & 9 & Highest \\
\hline National & 9.57 & 19.51 & 24.41 & 21.77 & 16.28 & 4.45 & 2.30 & 1.11 & 0.37 & 0.22 \\
Urban & 7.78 & 17.55 & 22.30 & 24.93 & 19.39 & 2.64 & 2.37 & 1.58 & 0.66 & 0.79 \\
Rural & 10.27 & 20.28 & 25.23 & 20.54 & 15.07 & 5.16 & 2.27 & 0.93 & 0.26 & 0.00 \\
Punjab & 9.91 & 18.58 & 29.05 & 23.09 & 14.64 & 2.70 & 1.35 & 0.68 & 0.00 & 0.00 \\
Sindh & 16.60 & 30.50 & 23.34 & 15.66 & 8.09 & 3.32 & 1.45 & 0.62 & 0.41 & 0.00 \\
KP & 0.69 & 5.54 & 17.09 & 22.40 & 29.33 & 12.70 & 6.47 & 3.23 & 1.15 & 1.39 \\
Baluchistan & 1.70 & 10.46 & 24.57 & 32.60 & 25.30 & 2.19 & 1.95 & 0.97 & 0.24 & 0.00 \\
\hline
\end{tabular}




\begin{tabular}{llllllll}
\hline \multicolumn{7}{l}{ C. subjective Well-being score in different regions/provinces of Pakistan } \\
\hline Average well-being & Nation & Urban & Rural & Punjab & Sindh & KP & Baluc. \\
\hline Female & 3.47 & 3.65 & 3.41 & 3.31 & 2.89 & 4.71 & 3.90 \\
Male & 3.36 & 3.27 & 3.39 & 3.14 & 3.00 & 4.22 & 3.75 \\
\hline
\end{tabular}

$N=2696$ Source: PPHS 2010, Baluc means Baluchistan, Authors', calculation

Table 3.4 summarizes the joint distribution of male and female subjective well-being within households. If there is a complete agreement between the two then the number of respondents in the non-diagonal cells would be zero (see Table 3.4). The matching of male and female respondents within household is not sufficiently higher. For example, out of total 240 female and 258 male respondents who said they were on the lowest rung of the ladder, only 52 male and female of the same household amongst them respond to the lowest well-being ladder. Nonetheless, the diagonal matrix is also looks dominant. It suggests that there is still exist enough overlap between the couple having the same economic position. In addition, the value of Cramer's V statistic is 0.19 that indicates that the association between the two variables is highly significant. In addition, the Spearman's rho and Gamma statistic is quite high and statistically significant. These findings confirm specific determinants lead to some non-overlapping responses of male and female subjective well-being question.

Despite enough overlapping responses of male and female subjective well-being, the t-test null hypothesis is rejected which indicates that the couple mean response is significantly different from each other. For this purpose, we tested the null hypothesis that there is no difference between the mean values of the couple subjective well-being. Looking at the probability that the outcome is in either tail of the distribution, we reject the null hypothesis that the mean value of the couple are significantly different from zero. Importantly, the probabilities associated with the two alternative hypotheses are well below 0.05 , we would reject the null hypothesis meaning that the two mean of subjective well-being are significantly different. Table 3.4 lower section shows the results of null hypothesis against alternative hypotheses.

\section{Table 3.4 Correlation matrix of both male and female subjective Well-being}

\begin{tabular}{llllllll}
\hline Categories & Lowest & 2 & 3 & 4 & 5 & $6+$ & Total \\
\hline Lowest & 52 & 90 & 54 & 30 & 7 & 7 & 240 \\
2 & 95 & 156 & 126 & 73 & 38 & 29 & 517 \\
3 & 73 & 151 & 232 & 221 & 126 & 39 & 842 \\
4 & 19 & 71 & 132 & 132 & 121 & 45 & 520 \\
5 & 8 & 29 & 75 & 92 & 104 & 80 & 388
\end{tabular}




$\begin{array}{llllllll}6+ & 11 & 29 & 39 & 39 & 43 & 28 & 189 \\ \text { Total } & 258 & 526 & 658 & 587 & 439 & 228 & 2696\end{array}$

t-test to compare mean(difference) value of couples subjective well-being

$\begin{array}{ll}\text { swbf } & 3.47 \\ \text { swbm } & 3.36 \\ \text { diff } & 0.12(0.03) * * *\end{array}$

Null hypothesis: diff in mean value is equal to zero

Ho: $\operatorname{mean}($ diff $)=0$

Three Alternatve hypotheses:

$\begin{array}{ll}\text { Ha: } \text { mean }(\text { diff })<0 & \operatorname{Pr}(\mathrm{T}<\mathrm{t})=0.999 \\ \text { Ha: mean }(\text { diff })=0 & \operatorname{Pr}(|\mathrm{T}|>\mathrm{t})=0.0004 \\ \text { Ha: } \text { mean }(\text { diff })>0 & \operatorname{Pr}(|\mathrm{T}|>\mathrm{t})=0.0002\end{array}$

Cramer's V $=0.189$, Pearson Chi2 $(25)=483.33 \operatorname{Pr}=0.000$, Spearman's rho $=0.371$ Prob $>|t|=0.000$, Gamma $=$ 0.372 ASE $=0.017$. The row shows the female economic situation, while column shows the male economic situation.

Note: we have added up all values from 6 to 10 and considered them as 6 . This is only limited for this correlation matrix for simplicity. The rows show the subjective well-being of female while columns show the male well-being.

\subsection{Empirical Model}

To analyze the determinants of gender subjective well-being, first, we use an ordered probit model. Second, in order to compare the gender subjective well-being differences, we use a robust linear regression analysis and a multinomial probit model as robust check (Greene 2011). ${ }^{18}$ The latent outcome variable denoted by $s w b_{i}^{*}$ ranging from $-\infty$ to $+\infty$ and is assumed to be a linear function of independent explanatory variables:

$$
s w b_{i}^{*}=\beta^{i} x_{i}+\epsilon_{i}
$$

Where $\mathrm{i}$ is the individual observation, $\epsilon_{i}$ is the corresponding error with standard normal distribution. The "swb" stands for subjective well-being. We use ten-scale (ladder) latent response variable ranging from the lowest economic position to the highest economic position. The observed categorical variable $s w b_{i}$ is related to unobserved $s w b_{i}^{*}$ by the threshold model define as:

\footnotetext{
${ }^{18}$ We utilize ordered probit model in our analysis given the nature of the data set. Using the ordered probit model sometime, the parallel regression assumption is violated. In this case, the generalized ordered probit is used as an alternative model. However, this model is very sensitive to low frequency counts. As a result, we have chosen to present the results of ordered probit model. In addition, we use the multinomial model, which is usually, used when the parallel regression assumption is violated.
} 


$$
s w b_{i}=\left\{\begin{array}{c}
1 \text { if }-\infty<s w b_{i}^{*} \leq \tau_{1} \\
2 \text { if } \tau_{1}<s w b_{i}^{*} \leq \tau_{2} \\
\cdot \\
10 \text { if } \tau_{9}<s w b_{i}^{*} \leq+\infty
\end{array}\right.
$$

Where, $\tau_{1}$ to $\tau_{9}$ be the threshold (cut-off) points. Given the independent variables, the probability of being observed response variable corresponds to the probability that the latent response variable lies between the corresponding thresholds.

$\operatorname{Pr}(s w b=1 \mid \mathrm{X})=\operatorname{Pr}\left(s w b_{i}^{*} \leq \tau_{1}\right)=\Pi_{1}$

$\operatorname{Pr}(s w b=2 \mid \mathrm{X})=\operatorname{Pr}\left(\tau_{1}<s w b_{i}^{*} \leq \tau_{2}\right)=\Pi_{2}-\Pi_{1}$

$\operatorname{Pr}(s w b=9 \mid \mathrm{X})=\operatorname{Pr}\left(\tau_{8}<s w b_{i}^{*} \leq \tau_{9}\right)=\Pi_{9}-\Pi_{8}$

$\operatorname{Pr}(s w b=10 \mid \mathrm{X})=\operatorname{Pr}\left(\tau_{9}<s w b_{i}^{*}\right)=1-\Pi_{9}$

Where $\Pi_{s}$ is the probability distribution function.

Table 3.1 elaborates the explanatory variables included in our model, and provides information about household demographic characteristics, household socio-economic characteristics, household food insecurity situation, community insecurity situation, regional and province dummies to control for regional heterogeneities. The econometric model for both male and female is specified as:

$s w b=b_{0}+b_{1}$ consumption $_{i}+b_{2}{\text { hh } \text { size }_{i}+b_{3}{\text { male } 18_{i}}+b_{4} \text { female } 8_{i}+b_{5} \text { age }}_{i}+$ $b_{6}(\text { age })_{i}^{2}+b_{7}$ educ $_{i}+b_{8}$ marital stautus $_{i}+b_{9}$ agriculture land $_{i}+b_{10}$ livestock $_{i}+$ $b_{11} \operatorname{assetTV}_{i}+b_{12}$ tv. consumption $_{i}+b_{13}$ house condition $_{i}+b_{14}$ water $_{i}+$ $b_{15}$ sanitation $_{i}+b_{16}$ food vulnerability $_{i}+b_{17}$ physical insecurity $i+b_{18}$ region $_{i}+$ $b_{19}$ province $_{i}+e_{i}$

The following sets of explanatory variables are considered necessary determinants of male and female subjective well-being in the literature.

\subsubsection{Comparison between male and female subjective well-being}

To compare the subjective well-being between male and female of the same household, we use robust linear least square regression by regression the male and female respondents' 
characteristics and household characteristics. ${ }^{19}$ For this purpose we generate the dependent variable (female-male discrepancy) using the difference of response of female and male subjective well-being. The value of the gender difference variable range from -7 to +8 . The value (-7) indicates that the subjective well-being of male is the highest and the value (8) shows that the subjective well-being of female is the highest and vice versa.

To check the robustness we use the multinomial probit model, which is a generalized form of probit model used when outcome variable takes on several categories. The model attempts to explain the relative effect of different explanatory variables on the outcome variable categories. The choices/categories are called alternatives and are coded as $j=1,2,3$. Our data consists of alternative-invariant or case specific regressor-the regressors vary over the individuals but do not vary over the alternative $\mathrm{j}$. The probability that individual $i$ select alternative $\mathrm{j}$ is given by:

$$
p_{i j}=p\left(y_{i}=j\right)=\theta\left(x_{i j}^{\prime} \beta\right)
$$

We utilize three alternatives of the outcome variable; Category 1 (Household with same subjective well-being), category 2 (Male subjective well-being is greater than female subjective well-being) and category 3 (Female subjective well-being is greater than male subjective wellbeing). In addition, Cramer's V test, Pearson Chi2, Spearman's rank correlation coefficient, and gamma test have been used.

\subsection{Empirical Results and Discussion}

\subsubsection{Determinants of male and female subjective well-being}

Table 3.5 shows the estimated results of male and female subjective well-being. Model- 1 and model-2 present male subjective well-being based on gender classification less than 18 years and 6 years of children, respectively. Model-3 and model- 4 describe female subjective well-being based on gender classification less than 18 years and 6 years of children, respectively.

Household per capita income is an important determinants of subjective well-being (Diener and Biswas-Diener 2002; Winkelmann 2005; Zhou and Yu, 2017). Money buys happiness. Specifically, the coefficient of per capita consumption is 0.25 and 0.56 for male and female respectively, which indicates that as per capita consumption increases, the economic situation of

\footnotetext{
${ }^{19}$ Robust regression is an alternative to Least Squares regression, works well with less restrictive assumptions. Specifically, when outliers are present in the data. Outliers violate the assumption of normality. Robust regression minimizes the outliers' impact on the coefficients estimates.
} 
household improves, and thus the subjective well-being improves significantly. Our results are in line with the previous studies (Diener et al. 1993; Pradhan and Ravallion 2000; Ravallion and Lokshin 2002; Lever 2004; Kingdon and Knight 2006; Stevenson and Wolfers 2013; Deeming 2013).

Similarly, demographic variables play an important role in determining the subjective wellbeing. For example, household size determines the economic situation of households' particularity in developing countries due to high dependency ratio. In contrast to objective measure of well-being, this study shows as the Household size increases, the chance of being well off improves significantly. For example, the coefficient of household size is 0.05 and 0.06 for male and female, respectively and it is statistically significant. Our findings are almost similar to the previous studies. Winkelmann (2005) finds that subjective well-being improves if income and household size increases proportionally. It means that for additional members of households, income equivalent scale should give a weight lower than one.

The well-being and age of the respondents association is quite opposite for male and female. Well-being is statistically insignificant U-shaped in age for male, while it is inverted U-shaped in age for female and it is statistically significant. The inverted U-shaped well-being indicates that initially well-being improves with age but after certain age, it starts decline for female. This means female at younger age are happier while in older age female well-being gradually declines. One possible interpretation could be the lack of proper social security system and health insurance for the elderly female. This study is quite contrast to the previous studies in that well-being is U-shaped in age (Frijters and Beatton 2012; Winkelmann 2005; Blanchflower and Oswald 2004). Moreover, Stone et al. (2010) find that well-being remain the same in age for both male and female. Regarding classification of children based on gender and their age group, the study confirms that with the same age group male prefers male children to female children. For instance, an increase in the number of male children under 6 years of age, leads to improve well-being by 0.06 percentage points in relative term. The motivation of this classification is to check the impact of children based on gender on the overall households' economic situation. Winkelmann (2005) examined that well-being of individuals within the same family is highly correlated.

In addition, the study finds a significant impact of education on subjective well-being of male and female respondents. For instance, the coefficients of education are 0.02 and 0.03 for male 
and female, respectively and it is statistically significant. The findings indicate that an additional year of schooling is associated with higher economic position. Importantly education generates employment opportunities, access to economic resources, self-satisfied life, stable social relationship, particularly marriage that enhances social support (Ross and Van Willigen 1997). On the contrary, if job offer does not match with education level that usually results in frustration thus negatively affects economic position of households (ILO 2005). This study is also consistent with Ravallion and Lokshin (2002) in that education results in improving subjective well-being. Happiness studies show complicated correlation between work and well-being. The current study also confirms that employment improves male respondent's well-being significantly. The study is consistent with previous studies such as being employed the subjective well-being of men increase significantly (Warr 1999; Winkelmann 2005). However, employed women are worse off in terms of subjective well-being compared to unemployed women. Similarly, household own residence is considered as an identity and class status in developing countries. The coefficient of own residence is 0.20 and 0.18 for male and female, respectively. It means that own residence improves well-being significantly. Moreover, improved drinking water and surprisingly livestock has no significant effect on the subjective well-being. However, sanitation facility and agriculture land holding has significant positive impact on female subjective wellbeing.

Food insecurity and physical insecurity of households have strong influence on human development and well-being. The coefficients of food insecurity are -0.36 and -0.72 for both male and female respectively. The estimated coefficients are statistically significant nonetheless for the female its impact is twice of the male respondent. Thus, it means that female value the household food insecurity high because usually the female control the household activities. Moreover, only physical insecurity deteriorates the male subjective well-being. Clearly, it is because actually male are more prone to terrorist activities. The findings delineate that food vulnerable and physically insecure households are likely to be worse off, even if the households' expenditure is controlled. Our results confirm that 2010 flood is the main cause behind this negative correlation between food insecurity and well-being that almost destroyed the agriculture sector. Moreover, the terrorist activities were also active in the survey time. Thus, the current study also confirms this negative correlation between physical insecurity and well-being. 
The results of households' assets and their interaction with income are quite interesting. For example, the households having assets, their impact on male well-being is negative and for female it is positive. It means that households assets, impact well-being of each respondent in different pattern. Nowadays, television has become a necessity of almost all households. However, the result shows that only female well-being improve significantly. Nevertheless, an increase in the households' income in combination with assets, the male subjective well-being improves significantly. For example, the interaction of income with assets leads to increase men subjective well-being from 0.25 to 0.41 while for women it decline from 0.56 for income to 0.42 when interacted with the assets of the households. Furthermore, the present analysis confirms that ownership of consumer durables raises subjective well-being (Ravallion and Lokshin 2002).

Finally, we use regional and provincial dummies to control for regional heterogeneities. Importantly the male individual living in the rural areas feels better, while female well-being remains insignificant in different regions. This finding is consistent with the previous result (Mangahas 1995). In addition, the KP province is the better off among the provinces while Sindh province is the worst-off particularly female member of the households that justify the results as the districts taken from the Sindh province is the least developed districts in the survey. The regional effect on subjective well-being can be due to perception of relative well-being, in that living in affluent areas people feel relatively worse off (Ravallion and Lokshin 2002).

We draw the following conclusion from the preceding discussion. First, the impact of determinants on the subjective well-being varies for male and female respondents. It means some variables are important for male while they are not important for female. Importantly the food insecurity, physical insecurity, employment, agriculture land holding, sanitation facility, and location of residence have different meaning for male and female welfare. Specifically, the food insecurity and sanitation determinants have high value for women than men whereas physical insecurity is important to men. Second, it is inevitable to consider their determinants and value them accordingly while measuring the well-being. 
Table 3.5 Order Probit models estimation results

\begin{tabular}{|c|c|c|c|c|}
\hline Variables & Model-1 ${ }^{\mathrm{a}}$ & Model- $2^{\mathrm{b}}$ & Model-3 $3^{\mathrm{c}}$ & Model-4 ${ }^{\mathrm{d}}$ \\
\hline \multicolumn{5}{|c|}{ Respondent Characteristics } \\
\hline \multicolumn{5}{|c|}{ Age of Respondents } \\
\hline \multirow{2}{*}{ Age } & -0.007 & -0.002 & $0.022 * *$ & $0.023 * *$ \\
\hline & $(0.011)$ & $(0.011)$ & $(0.010)$ & $(0.010)$ \\
\hline \multirow[t]{2}{*}{ Age square } & 0.000 & 0.000 & $-0.0002 * *$ & $-0.0003 * * *$ \\
\hline & $(0.0002)$ & $(0.0001)$ & $(0.0002)$ & $(0.0001)$ \\
\hline \multicolumn{5}{|c|}{ Respondent education (years of schooling as a continuous variable) } \\
\hline \multirow[t]{2}{*}{ Schooling } & $0.022 * * *$ & $0.023 * * *$ & $0.034 * * *$ & $0.033 * * *$ \\
\hline & $(0.005)$ & $(0.00580)$ & $(0.008)$ & $(0.008)$ \\
\hline \multicolumn{5}{|c|}{ Employment status (Reference category unemployed) } \\
\hline \multirow{2}{*}{ Employed } & $0.160 *$ & $0.171 * *$ & -0.023 & -0.025 \\
\hline & $(0.082)$ & $(0.082)$ & $(0.064)$ & $(0.063)$ \\
\hline \multicolumn{5}{|c|}{ Household Characteristics } \\
\hline \multicolumn{5}{|c|}{ Household size as a continuous variable } \\
\hline \multirow[t]{2}{*}{ Household Size } & $0.050 * * *$ & $0.048 * * *$ & $0.058 * * *$ & $0.064 * * *$ \\
\hline & $(0.012)$ & $(0.011)$ & $(0.012)$ & $(0.011)$ \\
\hline \multicolumn{5}{|c|}{ Gender classification } \\
\hline \multirow[t]{2}{*}{ Girls $<18$ years } & 0.027 & & 0.0189 & \\
\hline & $(0.017)$ & & $(0.018)$ & \\
\hline \multirow[t]{2}{*}{ Boys $<18$ years } & 0.012 & & 0.004 & \\
\hline & $(0.016)$ & & $(0.018)$ & \\
\hline \multirow[t]{2}{*}{ Girls $<6$ years } & & 0.046 & & 0.038 \\
\hline & & $(0.029)$ & & $(0.029)$ \\
\hline \multirow[t]{2}{*}{ Boys $<6$ years } & & $0.065^{* *}$ & & -0.032 \\
\hline & & $(0.028)$ & & $(0.030)$ \\
\hline \multicolumn{5}{|c|}{ Agriculture land (Reference category No) } \\
\hline \multirow[t]{2}{*}{ Yes } & 0.075 & 0.071 & $0.317 * * *$ & $0.316^{* * *}$ \\
\hline & $(0.055)$ & $(0.055)$ & $(0.054)$ & $(0.054)$ \\
\hline \multicolumn{5}{|c|}{ Residence status (Reference category No) } \\
\hline \multirow[t]{2}{*}{ Yes } & $0.201 * * *$ & $0.206^{* * *}$ & $0.178 * * *$ & $0.181 * * *$ \\
\hline & $(0.063)$ & $(0.063)$ & $(0.059)$ & $(0.059)$ \\
\hline \multicolumn{5}{|c|}{ Household Livestock (Reference category No) } \\
\hline \multirow[t]{2}{*}{ Yes } & 0.042 & 0.036 & 0.083 & 0.087 \\
\hline & $(0.078)$ & $(0.079)$ & $(0.076)$ & $(0.076)$ \\
\hline Household asset ( & 1) (Referenc & ory $\mathrm{No})$ & & \\
\hline Yes & $-1.288 * *$ & $-1.237 * *$ & $1.454 * *$ & $1.443 * *$ \\
\hline & $(0.618)$ & $(0.616)$ & $(0.614)$ & $(0.615)$ \\
\hline Household log of & a consumpt & & & \\
\hline Consumption PC & $0.254 * * *$ & $0.258 * * *$ & $0.565 * * *$ & $0.556 * * *$ \\
\hline & $(0.063)$ & $(0.062)$ & $(0.066)$ & $(0.065)$ \\
\hline Interaction term & tion and ass & & & \\
\hline Interation term & $0.161 * *$ & $0.156^{*}$ & $-0.149 *$ & $-0.148 *$ \\
\hline & $(0.079)$ & $(0.079)$ & $(0.079)$ & $(0.079)$ \\
\hline Food insecurity ( $\mathrm{r}$ & category $\mathrm{N}$ & & & \\
\hline Yes & $-0.366 * * *$ & $-0.360 * * *$ & $-0.726 * * *$ & $-0.725 * * *$ \\
\hline & $(0.052)$ & $(0.053)$ & $(0.056)$ & $(0.056)$ \\
\hline Physical insecurit & nce category & & & \\
\hline Yes & $-0.175 * * *$ & $-0.173 * * *$ & -0.062 & -0.058 \\
\hline
\end{tabular}




\begin{tabular}{|c|c|c|c|c|}
\hline Variables & Model-1 ${ }^{\mathrm{a}}$ & Model-2 ${ }^{\mathrm{b}}$ & Model-3 ${ }^{\mathrm{c}}$ & Model-4 $4^{\mathrm{d}}$ \\
\hline & $(0.055)$ & $(0.055)$ & $(0.056)$ & $(0.056)$ \\
\hline \multicolumn{5}{|c|}{ Water facility (reference category unimproved) } \\
\hline Improved & $\begin{array}{l}0.134 \\
(0.093)\end{array}$ & $\begin{array}{l}0.135 \\
(0.093)\end{array}$ & $\begin{array}{l}-0.105 \\
(0.076)\end{array}$ & $\begin{array}{l}-0.105 \\
(0.076)\end{array}$ \\
\hline \multicolumn{5}{|c|}{ Sanitation facility (reference category unimproved) } \\
\hline Improved & $\begin{array}{l}0.062 \\
(0.052)\end{array}$ & $\begin{array}{l}0.062 \\
(0.053)\end{array}$ & $\begin{array}{l}0.346 * * * \\
(0.052)\end{array}$ & $\begin{array}{l}0.346 * * * \\
(0.052)\end{array}$ \\
\hline \multicolumn{5}{|c|}{ Provinces (reference category Punjab) } \\
\hline Sindh & $\begin{array}{l}-0.051 \\
(0.058)\end{array}$ & $\begin{array}{l}-0.052 \\
(0.058)\end{array}$ & $\begin{array}{l}-0.234 * * * \\
(0.058)\end{array}$ & $\begin{array}{l}-0.230 * * * \\
(0.058)\end{array}$ \\
\hline KP & $\begin{array}{l}0.774 * * * \\
(0.072)\end{array}$ & $\begin{array}{l}0.789 * * * \\
(0.071)\end{array}$ & $\begin{array}{l}0.986 * * * \\
(0.072)\end{array}$ & $\begin{array}{l}0.987 * * * \\
(0.071)\end{array}$ \\
\hline Baluchistan & $\begin{array}{l}0.382 * * * \\
(0.062)\end{array}$ & $\begin{array}{l}0.396 \text { *** } \\
(0.062)\end{array}$ & $\begin{array}{l}0.215^{* * * *} \\
(0.075)\end{array}$ & $\begin{array}{l}0.221 * * * \\
(0.075)\end{array}$ \\
\hline \multicolumn{5}{|c|}{ Region (reference category Rural) } \\
\hline Urban & $\begin{array}{l}-0.250 * * * \\
(0.064)\end{array}$ & $\begin{array}{l}-0.246 * * * \\
(0.064)\end{array}$ & $\begin{array}{l}-0.007 \\
(0.059)\end{array}$ & $\begin{array}{l}-0.004 \\
(0.060)\end{array}$ \\
\hline Cut1 & $1.084 * *$ & $1.273^{* *}$ & $3.500 * * *$ & $3.441 * * *$ \\
\hline Cut2 & $1.986 * * *$ & $2.175 * * *$ & $4.502 * * *$ & $4.443 * * *$ \\
\hline Cut3 & $2.876^{* * *}$ & $3.065 * * *$ & $5.463 * * *$ & $5.405^{* * *}$ \\
\hline Cut4 & $3.445 * * *$ & $3.636 * * *$ & $6.314 * * *$ & $6.256 * * *$ \\
\hline Cut5 & $4.302 * * *$ & $4.494 * * *$ & $7.338 * * *$ & $7.281 * * *$ \\
\hline Cut6 & $4.810^{* * *}$ & $5.002 * * *$ & $7.867 * * *$ & $7.809 * * *$ \\
\hline Cut7 & $5.314 * * *$ & $5.509 * * *$ & $8.325 * * *$ & $8.266 * * *$ \\
\hline Cut8 & $6.038 * * *$ & $6.246 * * *$ & $8.859 * * *$ & $8.800 * * *$ \\
\hline Cut9 & $6.318 * * *$ & $6.530 * * *$ & $9.261 * * *$ & $9.202 * * *$ \\
\hline \multicolumn{5}{|l|}{ Diagnostic test } \\
\hline Wald Chi2 (21) & 494.21 & 500.94 & 1067.75 & 1063.93 \\
\hline Prob > Chi2 & 0.000 & 0.000 & 0.000 & 0.000 \\
\hline Pseudo R2 & 0.0748 & 0.0754 & 0.167 & 0.167 \\
\hline Log Pseudolikelihood & -321.592 & -321.388 & -295.297 & -295.238 \\
\hline Observations & 2,696 & 2,696 & 2,663 & 2,663 \\
\hline
\end{tabular}

Robust standard errors in parentheses; $* * * p<0.01, * * p<0.05, * p<0.1$

$a=$ Model 1: Ordered probit model scale-1 to scale-10 (Male subjective well-being gender classification less the 18 years),

$b=$ Model 2: Ordered probit model scale-1 to scale-10 (Male subjective well-being gender classification less the 6 years),

$c=$ Model 1: Ordered probit model scale-1 to scale-10 (Female subjective well-being gender classification less the 18 years),

$d=$ Model 2: Ordered probit model scale-1 to scale-10 (Female subjective well-being gender classification less the 6 years),

\subsubsection{Gender difference in the determinants of subjective well-being}

The second research question is whether there exist gender differences in the subjective wellbeing. This can be examined by analyzing the magnitude of any affect for a given change in the determinants on the difference in the respondents' subjective well-being. A negative coefficient 
of independent variable indicates that the subjective well-being of male is increasing and for female, it is decreasing. A positive coefficient of independent variable indicates that the subjective well-being of male is lower and for female, it is higher. Table 3.6 shows the gender difference in subjective well-being results and for robust check the multinomial findings. Model1 and model- 2 represent robust regression results, whereas model- 3 and model- 4 describe the multinomial findings. Most of the coefficients are not highly significant; however, some results are gender specific and highly significant.

For example, an additional year of schooling has a significant larger impact on the subjective well-being of women compared to men. In addition, the household having male children less than 6 years of age group the subjective well-being of men are higher compared to women wellbeing. This result is in line with these studies (Tian et al. 2018; Hadley et al. 2008). Furthermore, households with agriculture land holding the subjective well-being of women are higher compared to men. Similarly, the households who possess assets their subjective well-being of female increases compared to men. Similarly, the subjective well-being of women is larger than men with increasing per capita consumption household. Whereas with the interaction term of income with asset index the subjective well-being of men are significantly higher than women. Moreover, households facing food insecurity situation, has a larger significant negative impact on the subjective well-being of women than men. However, household confronted with physical insecurity scenario has a slightly larger effect on men subjective well-being than women. It means that men are prone to external physical insecurity and direct target of the unfavorable circumstances while women remains at home most of the times hence subjectively feel more secure. The food insecurity is more or less a household phenomenon, hence primarily concerned with women. The women well-being is significantly larger than men having improved sanitation facility. This finding is in line with the previous study by Jovanović (2017) for Serbia and Iran. Consequently, gender differences in subjective well-being can be related to gender specific activities (Tesch-Römer et al. 2008).

Comparing subjective well-being across provinces, women subjective well-being is lower than women in Sindh and Baluchistan provinces. It means, women of these two provinces are more deprived of compared to other provinces. Whereas, the gender difference in well-being of Punjab and KP are insignificant. In addition, women subjective well-being is significantly higher than men for urbanized localities. It means that in subjective term the rural men are happier while the 
urban women are happier. The reason could be that female has less access to urban areas that is why they prefer to live in urban areas.

Finally, as a robust test we use a multinomial models $(0,1$ and 2$)$ category- 0 where male and female subjective well-being remain the same category-1 where female (male) subjective wellbeing is less (greater) and category-2 where male (female) subjective well-being is less (greater). In this instance, we have taken category- 0 as a base category. This classification indicates a tendency of female to report high subjective economic position than male (40\% positive against $33 \%$ negative). This is consistent with the evidences reported in the previous literature (see Clark 1997) on job satisfaction, and (see Jovanovic 2017) for general satisfaction.

The households whose male subjective well-being is higher (category-1) and if he belongs to urban area having agriculture land and simultaneously faced with physical insecurity his subjective well-being will decline significantly. This can be confirmed from the findings of the statistically significant negative values of $-0.26,-0.30$ and -0.19 for physical insecurity, urban domain, and agriculture land ownership, respectively. However, the agriculture land coefficient is only significant at 10 percent significance level. This also envisages that female well-being improves with agriculture land holdings and their residence in urban areas. It means female respondent value agriculture land high that is consistent with the preceding findings. Similarly, for the households whose female subjective well-being is higher (category-2) a unit increase in per capita consumption, assets possession, and sanitation facilities improvement lead to increase subjective well-being of female by $0.40,4.50$ and 0.28 percentage points, respectively. This means that income, household assets, and sanitation play an important role in the improvement of female subjective well-being.

Moreover, the coefficient of food insecurity is negative for the households whose female subjective well-being is high. This indicates that the households experiencing food insecurity the subjective well-being of the female declines significantly. In the context of Pakistan where female have been facing discrimination historically, buffering is preferentially at male. Despite no differences in their households' food insecurity status the finding confirms that female is more likely to report being food insecure. These findings are consistent with the previous studies (Hadley et al. 2008). Furthermore, per capita consumption, assets, and improved sanitation results in increasing the subjective well-being of the households whose female subjective wellbeing is high. In addition, the negative statistically significant coefficients of interaction term 
(consumption and assets) and years of schooling can be interpreted in such a way that the male becomes better off with an additional year of schooling and increase in per capita consumption coupled with assets (for category-2 where male subjective well-being is low).

Importantly the results find no significant gender differences in well-being for the own residence, employment status, and age of the respondents. This could be due the fact that own residence has significant positive impact on both subjective well-being. Thus, we find no significant gender difference in them. In the same manner age and employment status matters individually but overall no significant gender differences exists between them.

All these findings and discussions reveal that there exit significant gender differences for some important variables in couple's subjective well-being but for most of the variables no significant differences were found. This also has been confirmed from a significant difference of mean value of couple subjective well- being, though enough overlapping between respondents response to well-being question. Hence, we conclude that there exist a significant gender differences in well-being, though the question is asked from the respondents on the household level. Similarly, the results of the multinomial models as a robust check are in line with the results of robust regression analysis. In addition, we test the link test for models specification. The results indicate that the prediction-squared coefficient is not significant. This confirms that all the models are specified correctly which are used in the analysis. The diagnostic statistics confirms the overall statistical significance of our models.

Table 3.6 Robust linear regression and multinomial models estimation results

\begin{tabular}{|c|c|c|c|c|c|c|}
\hline Variables & Model-1 ${ }^{\mathrm{a}}$ & Model-2 ${ }^{b}$ & Model-3 $3^{c}$ & & Model-4 ${ }^{\mathrm{d}}$ & \\
\hline & & & Category-2 & Category-3 & Category-2 & Category-3 \\
\hline \multicolumn{7}{|c|}{ Male Characteristics } \\
\hline \multicolumn{7}{|c|}{ Age of Respondent } \\
\hline \multirow[t]{2}{*}{ Age } & 0.029 & 0.028 & -0.004 & 0.019 & -0.003 & 0.020 \\
\hline & $(0.029)$ & $(0.028)$ & $(0.031)$ & $(0.032)$ & $(0.031)$ & $(0.031)$ \\
\hline \multirow[t]{2}{*}{ Age Square } & -0.0003 & -0.0003 & 0.0001 & 0.000 & 0.0001 & 0.000 \\
\hline & $(0.0003)$ & $(0.0002)$ & $(0.0003)$ & $(0.0002)$ & $(0.0002)$ & $(0.0002)$ \\
\hline \multicolumn{7}{|c|}{ Respondent education (years of schooling as a continuous variable) } \\
\hline \multirow{2}{*}{ Schooling } & -0.005 & -0.004 & -0.007 & $-0.018^{*}$ & -0.007 & $-0.018 *$ \\
\hline & $(0.009)$ & $(0.009)$ & $(0.011)$ & $(0.012)$ & $(0.011)$ & $(0.011)$ \\
\hline \multicolumn{7}{|c|}{ Employment status (Reference category unemployed) } \\
\hline \multirow[t]{2}{*}{ Employed } & -0.152 & -0.159 & -0.044 & -0.078 & -0.039 & -0.079 \\
\hline & $(0.132)$ & $(0.132)$ & $(0.164)$ & $(0.155)$ & $(0.164)$ & $(0.154)$ \\
\hline
\end{tabular}




\begin{tabular}{lllllll}
\hline Variables & Model- $^{\mathrm{a}}$ & Model-2 $^{\mathrm{b}}$ & Model-3 $^{\mathrm{c}}$ & \multicolumn{3}{c}{ Model-4 $^{\mathrm{d}}$} \\
\hline Age & & & Category-2 & Category-3 & Category-2 & Category-3 \\
& -0.002 & -0.008 & -0.031 & -0.036 & -0.027 & -0.038 \\
Age Square & $(0.028)$ & $(0.028)$ & $(0.033)$ & $(0.033)$ & $(0.034)$ & $(0.033)$ \\
& 0.0001 & 0.0002 & 0.0001 & 0.0002 & 0.0001 & 0.0002 \\
& $(0.0003)$ & $(0.0003)$ & $(0.0004)$ & $(0.0003)$ & $(0.0003)$ & $(0.0003)$
\end{tabular}

Respondent education (years of schooling as a continuous variable)

$\begin{array}{lllllll}\text { Schooling } & 0.030^{* *} & 0.031 * * & -0.015 & 0.016 & -0.016 & 0.016 \\ & (0.015) & (0.014) & (0.019) & (0.018) & (0.019) & (0.018)\end{array}$

Employment status (Reference category unemployed)

$\begin{array}{lllllll}\text { Employed } & -0.159 & -0.163 & 0.132 & -0.022 & 0.134 & -0.025 \\ & (0.112) & (0.111) & (0.137) & (0.139) & (0.138) & (0.138)\end{array}$

Household Characteristics

Household size as a continuous variable

$\begin{array}{lllllll}\text { Household size } & -0.003 & 0.006 & 0.026 & 0.028 & 0.020 & 0.031 \\ & (0.020) & (0.018) & (0.024) & (0.024) & (0.023) & (0.022)\end{array}$

Gender classification

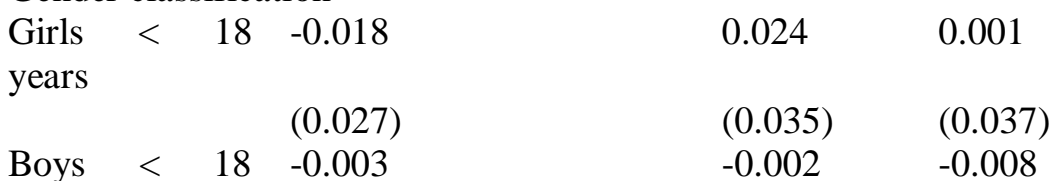

$\begin{array}{llll}\begin{array}{l}\text { Boys }<18 \\ \text { years }\end{array} & -0.003 & -0.002 & -0.008 \\ & (0.028) & (0.034) & (0.035)\end{array}$

Girls $<6$ years $\quad-0.026$

$\begin{array}{ll}\text { Boys }<6 \text { years } & (0.047) \\ & -0.108 * *\end{array}$

(0.046)

Agriculture land (Reference category No)

$\begin{array}{lllllll}\text { yes } & 0.239 * * * & 0.242 * * * & -0.190 * & -0.002 & -0.194 * & -0.004 \\ & (0.087) & (0.087) & (0.113) & (0.116) & (0.113) & (0.116)\end{array}$

Residence status (Reference category No)

$\begin{array}{lllllll}\text { Yes } & -0.077 & -0.083 & 0.005 & -0.042 & 0.012 & -0.042 \\ & (0.101) & (0.101) & (0.121) & (0.127) & (0.121) & (0.127)\end{array}$

Household Livestock (Reference category No)

$\begin{array}{lllllll}\text { Yes } & 0.040 & 0.051 & -0.099 & -0.099 & -0.103 & -0.089 \\ & (0.127) & (0.127) & (0.149) & (0.151) & (0.149) & (0.151)\end{array}$

Household asset (television) (Reference category No)

Yes $\quad 2.983 * * * 2.881 * * *-0.180$

$$
\begin{array}{lll}
2.983 * * * & 2.881 * * * & -0.180 \\
(1.025) & (1.022) & (1.208)
\end{array}
$$

$4.505^{* * *}$

$\begin{array}{ll}0.048 & 0.053 \\ (0.058) & (0.062)\end{array}$

$0.051 \quad-0.088$

$(0.058) \quad(0.060)$

Household log of per capita consumption
Consumption $0.231 * * \quad 0.214 * *$
$0.097 \quad 0.402 * * *$

$-0.113$

$4.507 * * *$

PC
$(0.100)$
$(0.097)$
$(0.118)$
$(0.127)$
$(0.116)$
$(0.125)$

Interaction term (consumption and asset)

Interation term $\quad-0.341 * * \quad-0.329 * *$

$$
\begin{aligned}
& (0.134) \quad(0.133) \\
& (\text { reference category No) }
\end{aligned}
$$

$0.018 \quad-0.534 * * * \quad 0.010 \quad-0.535 * * *$

Food insecurity (reference category No)
Yes
$-0.363 * * * \quad-0.368 * * *$
0.033
$(0.112)$
$-0.242 * *$
0.035
$-0.245^{* *}$
$(0.112)$
$(0.113)$
(0.112)

$(0.161)$

$(0.158)$

$(0.161)$

Physical insecurity (reference category No)
Yes
$0.155^{*}$
$0.155^{*}$

$\begin{array}{llll}-0.262 * * & -0.032 & -0.261 * * & -0.030\end{array}$ 
He Said, She Said: Unpacking Pakistan's Intra-household Gender...

\begin{tabular}{|c|c|c|c|c|c|c|}
\hline Variables & Model-1 $^{\mathrm{a}}$ & Model- $2^{\mathrm{b}}$ & Model-3 ${ }^{\mathrm{c}}$ & & Model-4 ${ }^{\mathrm{d}}$ & \\
\hline & $(0.086)$ & $(0.086)$ & $\begin{array}{l}\text { Category-2 } \\
(0.120)\end{array}$ & $\begin{array}{l}\text { Category-3 } \\
(0.117)\end{array}$ & $\begin{array}{l}\text { Category-2 } \\
(0.120)\end{array}$ & $\begin{array}{l}\text { Category-3 } \\
(0.117)\end{array}$ \\
\hline \multicolumn{7}{|c|}{ Water facility (reference category unimproved) } \\
\hline Improved & $\begin{array}{l}-0.206 \\
(0.134)\end{array}$ & $\begin{array}{l}-0.207 \\
(0.134)\end{array}$ & $\begin{array}{l}0.106 \\
(0.173)\end{array}$ & $\begin{array}{l}-0.220 \\
(0.181)\end{array}$ & $\begin{array}{l}0.108 \\
(0.172)\end{array}$ & $\begin{array}{l}-0.222 \\
(0.181)\end{array}$ \\
\hline \multicolumn{7}{|c|}{ Sanitation facility (reference category unimproved) } \\
\hline Improved & $\begin{array}{l}0.290 * * * \\
(0.085)\end{array}$ & $\begin{array}{l}0.288 * * * \\
(0.085)\end{array}$ & $\begin{array}{l}-0.071 \\
(0.103)\end{array}$ & $\begin{array}{l}0.286^{* * * *} \\
(0.105)\end{array}$ & $\begin{array}{l}-0.069 \\
(0.103)\end{array}$ & $\begin{array}{l}0.287 * * * \\
(0.105)\end{array}$ \\
\hline \multicolumn{7}{|c|}{ Provinces (reference category Punjab) } \\
\hline Sindh & $\begin{array}{l}-0.178 * * \\
(0.089)\end{array}$ & $\begin{array}{l}-0.171^{*} \\
(0.090)\end{array}$ & $\begin{array}{l}0.150 \\
(0.110)\end{array}$ & $\begin{array}{l}-0.171 \\
(0.113)\end{array}$ & $\begin{array}{l}0.146 \\
(0.110)\end{array}$ & $\begin{array}{l}-0.174 \\
(0.113)\end{array}$ \\
\hline $\mathrm{KP}$ & $\begin{array}{l}0.135 \\
(0.123)\end{array}$ & $\begin{array}{l}0.117 \\
(0.122)\end{array}$ & $\begin{array}{l}0.187 \\
(0.144)\end{array}$ & $\begin{array}{l}0.045 \\
(0.139)\end{array}$ & $\begin{array}{l}0.199 \\
(0.145)\end{array}$ & $\begin{array}{l}0.042 \\
(0.140)\end{array}$ \\
\hline Baluchistan & $\begin{array}{l}-0.202^{*} \\
(0.116)\end{array}$ & $\begin{array}{l}-0.209^{*} \\
(0.116)\end{array}$ & $\begin{array}{l}0.013 \\
(0.156)\end{array}$ & $\begin{array}{l}-0.048 \\
(0.153)\end{array}$ & $\begin{array}{l}0.016 \\
(0.155)\end{array}$ & $\begin{array}{l}-0.049 \\
(0.153)\end{array}$ \\
\hline \multicolumn{7}{|c|}{ Region (reference category Rural) } \\
\hline Urban & $\begin{array}{l}0.283 * * * \\
(0.102)\end{array}$ & $\begin{array}{l}0.280 * * * \\
(0.103)\end{array}$ & $\begin{array}{l}-0.305 * * \\
(0.132)\end{array}$ & $\begin{array}{l}0.081 \\
(0.128)\end{array}$ & $\begin{array}{l}-0.303 * * \\
(0.132)\end{array}$ & $\begin{array}{l}0.078 \\
(0.129)\end{array}$ \\
\hline Constant & $\begin{array}{l}-2.015^{* *} \\
(0.859) \\
\end{array}$ & $\begin{array}{l}-1.687^{*} \\
(0.862) \\
\end{array}$ & $\begin{array}{l}0.211 \\
(1.020) \\
\end{array}$ & $\begin{array}{l}-2.185^{* *} \\
(1.111) \\
\end{array}$ & $\begin{array}{l}-0.014 \\
(1.038) \\
\end{array}$ & $\begin{array}{l}-2.133^{*} \\
(1.125) \\
\end{array}$ \\
\hline \multicolumn{7}{|l|}{ Diagnostic Test } \\
\hline R-squared & 0.093 & 0.095 & & & & \\
\hline $\mathrm{F}(2,2660)$ & 105.93 & 108.23 & & & & \\
\hline Prob $>\mathrm{F}$ & 0.000 & 0.000 & & & & \\
\hline Root MSE & 1.649 & 1.647 & & & & \\
\hline Wald Chi2 (50) & & & 219.08 & & 224.43 & \\
\hline Prob $>$ Chi2 & & & 0.000 & & 0.000 & \\
\hline Pseudo & & & -199.204 & & $-198 . .914$ & \\
\hline \multirow{2}{*}{\multicolumn{7}{|c|}{$\begin{array}{l}\text { likelihood } \\
\text { Link Test for Model Specification }\end{array}$}} \\
\hline & & & & & & \\
\hline _hat & $\begin{array}{l}0.984 * * * \\
(0.077)\end{array}$ & $\begin{array}{l}0.985^{* * *} \\
(0.075)\end{array}$ & & & & \\
\hline _hatsq & $\begin{array}{l}0.037 \\
(0.110)\end{array}$ & $\begin{array}{l}0.037 \\
(0.108)\end{array}$ & & & & \\
\hline Observations & 2,663 & 2,663 & 2,663 & 2,663 & 2,663 & 2,663 \\
\hline
\end{tabular}

Robust standard errors in parentheses; $* * * p<0.01, * * p<0.05, * p<0.1$

$a=$ Model 1: Robust Least Square Regression (Gender difference subjective well-being, gender classification less the 18 years),

$b=$ Model 2: Robust Least Square Regression (Gender difference subjective well-being, gender classification less the 6 years),

$c=$ Model 3: Multinomial model based on gender classification less than 18 years (base=neutral, male, female), neutral $=0$ male well-being is greater $=1$, female well-being is greater $=2$

$d$ =Model 4: Multinomial model based on gender classification less than 6 years (base=neutral, male, female), neutral $=0$ male well-being is greater $=1$, female well-being is greater $=2$ 


\subsection{Conclusion and policy recommendations}

This study investigates the determinants of subjective well-being of male and female within household as well as their intra-household gender differences in subjective well-being. To this end, we use Pakistan Panel Household Survey 2010 data, where each respondent classify themselves on a ten-scale ranking from the lowest well-being position to the highest within household. The results indicate that per capita income, schooling, household size, own residence, asset possession, agriculture land holdings, sanitation facility, physical insecurity, and food insecurity are the main determinants of subjective well-being. Nevertheless, the findings indicate statistically significant gender differences in the mean value of subjective well- being. Similarly there exists enough overlap of respondents' responses to subjective well-being question; however there are some important variables that impact the male and female well-being differently. So we conclude a statistically significant gender differences in couple subjective well- being.

Thus gender difference in well-being results delineate that individual specific predictors play their part in the deviation or generating the gender gap in their subjective well-being. Particularly the important drivers of the gender gap are education, agriculture land holdings, children classification based on gender, physical, and food insecurity. To narrow down the analysis, female individual specific determinants are schooling, assets and agriculture land holding, food insecurity and sanitation facility. For male per capita consumption and assets interaction, gender classification of male children and physical insecurity are the driving force behind this discrepancy. Moreover, food insecurity imparts more negative impact on female subjective wellbeing, whereas, physical insecurity is mainly concerned with male subjective well-being. In addition, the results of robust check based on the multinomial model are in line with the aforementioned measures.

Keeping in view the above findings, the implication and policy recommendations of the study are first, subjective measure of well-being is influenced by numerous factors along with income. Second, categorization of gender on subjective economic grounds capture well the impact of specific determinants. Third, investigating gender differences enrich the existing literature of subjective well-being. Fourth, the study magnifies the sensitivity of different well-being measures. Hence gender difference is subjective well-being could be related to gender specific access to goal relevant resources. For example, human development indicator such as education 
and a pressing public health concern such as food insecurity, significantly affects female wellbeing. In the context of Pakistan, for policy makers it is imperative to set programs that impart education and improve food security for the enhancement of female well-being. In general, the public programs such as women education, housing policy, food policy, and security level should be in line with these findings. The local government should be involved to point out the targeted groups based on subjective measure for human development indicators and socio-economic development. The security situations should be prioritizing in order to ensure security and to open room for the improvement of living standards given the limited coping strategies. The implication of this paper is that it is not safe to rely on only one dimension to measure well-being 


\subsection{References}

Alessie, R., Crossley, T. F., Hildebrand, V. (2006). Estimating a collective household model with survey data on financial satisfaction (No. 06/19). IFS Working Papers, Institute for Fiscal Studies (IFS).

Alkire, S. (2007). The Missing Dimensions of Poverty Data: Introduction to the Special Issue. Oxford Development Studies, 35(4), 347-359

Andress, H. J., Bröckel, M. (2007). Income and life satisfaction after marital disruption in Germany. Journal of Marriage and Family, 69(2), 500-512.

Bennett, F., De Henau, J., Himmelweit, S., Sung, S. (2012). Financial togetherness and autonomy within couples. Gendered lives: Gender inequalities in production and reproduction, Cheltenham, UK and Northampton, MA, USA: Edward Elgar Publishing, 97-122.

Blanchflower, D. G., and Oswald, A. J. (2008). Is well-being U-shaped over the life cycle? Social science \& medicine, 66(8), 1733-1749.

Bonke, J., and Browning, M. (2009). The distribution of financial well-being and income within the household. Review of Economics of the Household, 7(1), 31-42.

Clark, A. E. (1997). Job satisfaction and gender: why are women so happy at work?. Labour economics, 4(4), 341-372.

Deeming, C. (2013). Addressing the Social Determinants of Subjective Wellbeing: The Latest Challenge for Social Policy. Journal of Social Policy, 42(3), 541-565.

Diener, E., Sandvik, E., Seidlitz, L., and Diener, M. (1993). The relationship between income and subjective well-being: Relative or absolute? Social Indicators Research, 28(3), 195223.

Diener, E., Suh, E. M., Lucas, R. E., and Smith, H. L. (1999). Subjective well-being: Three decades of progress. Psychological bulletin, 125(2), 276.

Diener, E., and Biswas-Diener, R. (2002). Will money increase subjective well-being?.Social indicators research, 57(2), 119-169.

Diener, E., \& Lucas, R. E. (1999). Personality and subjective well-being. Well-being: Foundations of hedonic psychology, 213-229 
Dolan, P., Peasgood, T., and White, M. (2008). Do we really know what makes us happy? A review of the economic literature on the factors associated with subjective well-being. Journal of economic psychology, 29(1), 94-122.

Easterlin, R. A. (2001). Life cycle welfare: trends and differences. Journal of happiness studies, 2(1), 1-12.

Frey, B. S., and Stutzer, A. (2002). The economics of happiness. World economics, 3(1), 1-17.

Frijters, P., and Beatton, T. (2012). The mystery of the U-shaped relationship between happiness and age. Journal of Economic Behavior \& Organization, 82(2-3), 525-542.

Gandelman, M. L. A. N. (2013). Happiness decomposition: female optimism.

Graham, C., and Pettinato, S. (2001). Happiness, markets, and democracy: Latin America in comparative perspective. Journal of Happiness Studies, 2(3), 237-268.

Graham, C., and Chattopadhyay, S. (2012). Gender and well-being around the world: Some insights from the economics of happiness. The Brookings Institution, University of Chicago, Chicago, USA.

Greene, W. H. (2011). Econometric Analysis (7 ${ }^{\text {th }}$ edition). ISBN-13, 978-0131395381.

Hadley, C., Lindstrom, D., Tessema, F., and Belachew, T. (2008).Gender bias in the food insecurity experience of Ethiopian adolescents. Social science \& medicine, 66(2), 427438.

Helliwell, John F., Richard Layard, and Jeffrey Sachs, eds. 2015. World Happiness Report 2015.New York: Sustainable Development Solutions Network.

International Labour Oragnisation (ILO), (2005). Socioeconomic security for a better World.Geneva: ILO.

Jovanovic, V., Joshanloo, M., Đunda, D., Bakhshi, A. (2017).Gender differences in the relationship between domain-specific and general life satisfaction: A study in Iran and Serbia. Applied Research in Quality of Life, 12(1), 185-204.

Kalugina, E., Radtchenko, N., Sofer, C. (2009). How do spouses share their full income? Identification of the sharing rule using self-reported income. Review of Income and Wealth, 55(2), 360-391.

Kingdon, G. G., and Knight, J. (2006). Subjective well-being poverty vs. Income poverty and capabilities poverty? The Journal of Development Studies, 42(7), 1199-1224. 
Knight, J., Lina, S. O. N. G., and Gunatilaka, R. (2009). Subjective well-being and its determinants in rural China. China economic review, 20(4), 635-649.

Lever, J. P. (2004). Poverty and Subjective Well-being in Mexico. Social Indicators Research, $68(1), 1-33$.

Mangahas, M. (1995). Self-rated poverty in the Phillippines, 1981-1992. International Journal of Public Opinion Research, 7(1), 40-52.

Mies, M. (1982). The lace makers of Narsapur: Indian house wives produce for the world market. Zed Books.

Nolen-Hoeksema, S., and Rusting, C. L. (2003). Gender Differences in Well-Being. In D. Kahneman, E. Diener, N. Schwarz. Well-being: Foundations of hedonic psychology, 330352.New York, NY: Russel Sage Foundation.

Pradhan, M., and Ravallion, M. (2000). Measuring Poverty Using Qualitative Perceptions of Consumption Adequacy. The Review of Economics and Statistics, 82(3), 462-471.

Ravallion, M., and Lokshin, M. (2002).Self-rated economic welfare in Russia. European Economic Review, 46(8), 1453-1473.

Riffault H. (1991) How Poverty is Perceived. In: Reif K., Inglehart R. (eds) Eurobarometer. Palgrave Macmillan, London

Ross, C. E. (1991). Marriage and the sense of control. Journal of Marriage and the Family, 534, 831-838.

Ross, C. E., and Van Willigen, M. (1997). Education and the subjective quality of life. Journal of health and social behavior, Vol. 38, No. 3, Health Professions: Socialization, Organization, Utilization (Sep., 1997), pp. 275-297.

Sen, A. (1988). The Standard of Living. Cambridge University Press

Sen, A. (1985). Commodities and Capabilities. New Delhi: Oxford University Press.

Senik, C. (2004). When information dominates comparison: Learning from Russian subjective panel data.Journal of Public Economics, 88(9), 2099-2123.

Shams, K. (2014). Determinants of Subjective Well-Being and Poverty in Rural Pakistan: A Micro-Level Study. Social Indicators Research, 119(3), 1755-1773.

Stevenson, B., and Wolfers, J. (2009). The paradox of declining female happiness. American Economic Journal: Economic Policy, 1(2), 190-225. 
Stevenson, B., and Wolfers, J. (2013). Subjective well-being and income: Is there any evidence of satiation? The American Economic Review, 103(3), 598-604.

Stevenson, B., and Wolfers, J. (2009). The paradox of declining female happiness. American Economic Journal: Economic Policy, 1(2), 190-225.

Stone, A. A., Schwartz, J. E., Broderick, J. E., Deaton, A. (2010).A snapshot of the age distribution of psychological well-being in the United States. Proceedings of the National Academy of Sciences, 107(22), 9985-9990.

Tesch-Römer, C., Motel-Klingebiel, A., and Tomasik, M. J. (2008). Gender differences in subjective well-being: Comparing societies with respect to gender equality. Social Indicators Research, 85(2), 329-349.

Tian, X., Yu, X., Klasen, S. (2018). Gender discrimination in China revisited: a perspective from family welfare. Journal of Chinese Economic and Business Studies, 16(1), 95-115.

Veira-Lima, Sabrina (2011). "A Cross-Country Investigation of the Determinants of the Happiness Gender Gap", Mimeo, University of Milan-Bicocca, Department of Economics, Milan, Italy.

Warr, P. (1999). Well-Being and the Workplace. In D. Kahneman, E. Diener, \& N. Schwarz (Eds.), Well-Being: The Foundations of Hedonic Psychology (pp. 392-412). New York: Russell Sage Foundation.

Winkelmann, R. (2005). Subjective well-being and the family: Results from an ordered probit model with multiple random effects. Empirical Economics, 30(3), 749-761.

Zhou, S., and Yu, X. (2017).Regional Heterogeneity of Life Satisfaction in Urban China: Evidence from Hierarchical Ordered Logit Analysis. Social Indicators Research, 132(1), 25-45.

Zweig, J. S. (2015). Are women happier than men? Evidence from the Gallup World Poll. Journal of Happiness Studies, 16(2), 515-541. 


\section{Appendix:}

Table 3.7 Weighting schemes of sample households

\begin{tabular}{|c|c|c|c|c|c|c|}
\hline Districts & $\begin{array}{l}\text { Total } \\
\text { population }\end{array}$ & $\begin{array}{l}\text { Sample } \\
\text { population }^{\mathrm{b}}\end{array}$ & $\begin{array}{l}\text { pweights } \\
{\left[(T P)_{i} /(S P)_{i}\right]}\end{array}$ & $\begin{array}{l}\text { pw- } \\
\text { normalized } \\
{\left[(P W)_{J} \wedge(P W)_{j}\right]}\end{array}$ & $\begin{array}{l}\text { Pwn-Urban } \\
{\left[(P W u)_{J}\right.} \\
\left.\sum(P W u)_{j}\right]\end{array}$ & $\begin{array}{l}\text { pwn-Rural } \\
{\left[(P W r)_{J}\right.} \\
\left.\sum \sum(P W r)_{j}\right]\end{array}$ \\
\hline & $(\mathrm{TP})_{\mathrm{j}}$ & $(\mathrm{SP})_{\mathrm{j}}$ & $(\mathrm{PW})_{\mathrm{J}}$ & $(\mathrm{PWN})_{\mathrm{J}}$ & $(\mathrm{PWNu})_{\mathrm{J}}$ & $(\mathrm{PWNr})_{\mathrm{J}}$ \\
\hline Faisalabad & 5429547 & 3031 & 1791.33 & 0.207 & 0.166 & 0.172 \\
\hline Attock & 1274935 & 1344 & 948.61 & 0.093 & 0.083 & 0.081 \\
\hline Hafizabad & 1136044 & 3648 & 311.41 & 0.049 & 0.041 & 0.023 \\
\hline Vehari & 717649 & 2563 & 280.00 & 0.045 & 0.034 & 0.021 \\
\hline Muzafargarh & 832980 & 1785 & 466.65 & 0.038 & 0.055 & 0.035 \\
\hline Bahawalpur & 2090416 & 1895 & 1103.12 & 0.090 & 0.074 & 0.097 \\
\hline Badin & 2635903 & 1972 & 1336.66 & 0.055 & 0.082 & 0.117 \\
\hline Nawabshah & 2433091 & 2406 & 1011.26 & 0.079 & 0.113 & 0.078 \\
\hline MirpurKhas & 1071533 & 2237 & 479.00 & 0.049 & 0.054 & 0.036 \\
\hline Larkana & 905935 & 1603 & 565.14 & 0.029 & 0.060 & 0.045 \\
\hline Dir & 1927066 & 2545 & 757.19 & 0.093 & 0.069 & 0.065 \\
\hline Mardan & 1460100 & 1872 & 779.96 & 0.063 & 0.049 & 0.075 \\
\hline LakkiMarwat & 490025 & 543 & 902.44 & 0.047 & 0.032 & 0.090 \\
\hline loralai & 297554 & 1409 & 211.18 & 0.019 & 0.010 & 0.019 \\
\hline Kuzdar & 417466 & 937 & 445.53 & 0.026 & 0.045 & 0.035 \\
\hline Gwadar & 185498 & 1220 & 152.04 & 0.010 & 0.026 & 0.008 \\
\hline Total & 23305743 & 31010 & 11541.59 & 1 & 1 & 1 \\
\hline
\end{tabular}




\section{Chapter 4 What determines food (in)security in Pakistan? New evidence using Food Insecurity Experience Scale Survey Module (FIES-SM)}

\subsection{Introduction}

It is often said, "Food insecurity anywhere threatens peace everywhere". In fact, food security reflects the desire to eradicate hunger and malnutrition. The World Food Summit 1996 defined food security as "when all people at all times have physical and economic access to sufficient, safe, and nutritious food to dietary needs and food preferences for an active and healthy life". Food insecurity is ubiquitous as more than 800 million people are undernourished across the globe (FAO 2013). Moreover, food insecurity on the rise in developing countries, even though production double during the last three decades to meet the rising demand of food (FAO 2009). The target of reducing extreme poverty rates by half was met five years ahead of the 2015 deadline. In addition the second United Nations Sustainable Development Goal (SDG2) aims to "end hunger, achieve food security and improved nutrition and promote sustainable agriculture" for all people by 2030. Globally hunger and malnutrition has declined but food security is still remained a big challenge. Despite the progress, one in nine individual does not have enough food to eat. Global trend in hunger reduction disguise among different region $\left(69^{\text {th }}\right.$ United Nations General Assembly debate).

Pakistan has experienced rise in food insecurity during the last decade owing to conflicts, natural disasters, and economic instability. Pakistan has ranked $11^{\text {th }}$ worst among 118 countries in the Global Hunger Index (IFPRI 2016). Importantly in 2010, worst natural disaster hit Pakistan where flood submerged the agriculture land, destroyed infrastructure and leaving 20 million people without access to food, clean drinking water, health facilities, and severely affected agriculture sector (World Food Program 2012). The estimate shows that almost 90 million people were food insecure in the aftermath of flood 2010. Furthermore, terrorist activities coupled with political instability resulted in huge financial cost which is manifested in the form of internally displaced people, widespread unemployment, skyrocketing food prices in 2010 (World Food Program 2012). Subsequently, it is imperative to discuss and examine food insecurity scenario across Pakistan. Importantly the timing and relevance of the study allow us to investigate households' food insecurity at the micro level. 
Food insecurity is a multidimensional phenomenon that encompasses different regional, community and household level factors. However, common accepted metric to measure the determinants of food insecurity across different countries has so for been lacking. Specifically, the conventional model-based (calories available per capita at the national level (FAO), household income and expenditure procedures, individuals' dietary intake, anthropometry) estimates are inconsistent (Barret 2010; Masset 2011; Klasen 2008; Svedberg 2002). This inconsistent understanding regarding food insecurity is potentially changing by using the microlevel metric food insecurity experience scale measure (FIES). Therefore, a common measure of determinants of food insecurity is inevitable to meet the target laid out by sustainable development goal 2 (SDG2) and to put forward interventionary policy options. To this end the Voices of the Hungry ( $\mathrm{VoH}) 2013$ project of the FAO has developed an experiential approach of food insecurity. The Food Insecurity Experience Scale (FIES) aimed at producing comparable annual estimates of food insecurity around different countries. This method classifies to identify households and individuals based on the ranking of food insecurity severity. Originally, this approach was adopted in the US, similar tools followed in various parts of the world that include quantitative, qualitative, psychological and social dimension of food security coupled with cost effective measure of food insecurity.

Many studies have validated experiential food insecurity scales over the past decades (Coates et al. 2003; Coates et al. 2006; Webb et al. 2006; Frongillo and Nanama 2006; Nord 2012; Smith et al. 2017a; Smith et al. 2017b). However, very limited studies are available on Pakistan's food insecurity measure. Importantly the available literature utilizes the conventional measures of food insecurity. For example the following studies have focused on Pakistan (Abdullah et al. 2017; Rasul and Hussain 2015; Mahmood et al. 2014; Asghar and Muhammad 2013; Gazdar and Mallah 2013; Bashir et al. 2013; Khan and Shah 2011; Ahmad 2009; Baig-Ansari et al. 2006; Uzma and Muhammad 2004). Among them (Bashir and Schilizzi 2015) examined the impact of short term policies on small holder farmers' food security for the Punjab province of Pakistan. The study analysis two-demand side policies such as food subsidy and minimum wage rate and two supply side policies such as wheat support price and urea subsidy. Each of these policies has improved farmers' food security. However, their potential benefits are reduced substantially due to their poor implementation. 
Food is a basic need of every human being for growth and development and is one of the important fundamental rights. According to National Nutrition Survey (2011), multiple factors that involve several sectors contribute to food insecurity and under nutrition with different levels of causalities. The report delineates very high prevalence of chronic malnutrition for Pakistan. For example, wasting is greater than 15 percent, stunting is 43.7 percent, and underweight is 31.5 percent among children under five years of age. The survey also depicts that over 50 percent of women are suffering from anemia and 15 percent of women are suffering from caloric deficiency. Therefore, the basic objective of the study is to investigate the determinants of household food insecurity. In addition, the current study point out those determinants, which are important for the food insecure vulnerable households.

Using Pakistan Panel Household Survey data 2010, we use an ordered probit, and a probit and linear probability models as robust check to investigate the determinants of food insecurity. Similarly, to understand the linkage between food security, poverty, and inflationary shocks, we use non-parametric analysis between household income, inflation, and food security. The analysis predicts significant micro level determinants of food insecurity such as conflicts, natural disasters, and escalating food prices during 2010. Importantly we find a significant positive trend between food security and poverty reduction, and negative relationship between food security and inflation. As food insecurity is a multi-dimensional phenomenon incorporating various factors in the analysis will substantially fill the research gap and enable the policy makers in better understanding the food insecurity at micro level. The current situation of the country is not quite different from the 2010 period, so the findings are equally important for future policy recommendations and implementations regarding improving the food security situation of the targeted groups. Therefore, specific interventions policies for food security, coupled with nutritional awareness and safety nets programs are required to address the issue of food insecurity.

The rest of the paper is organized as follows. Section 2 discusses data design, variables, and descriptive statistics. Section 3 presents the empirical method followed by empirical results and discussions in section 4. Finally, section 5 concludes and gives some policy recommendations. 


\subsection{Data design, hypothesis, variables, and descriptive statistics}

\subsubsection{Research design and hypothesis}

Our analysis is based on the third round Pakistan Panel Household Survey (PPHS) in 2010, a joint project of the Pakistan Institute of Development Economics (PIDE) and the World Bank. The sample size is 4142 households covering four provinces of which 2800 are rural and 1342 urban households. ${ }^{20}$ After cleaning the data with missing variables, we obtained 3730 households consisting of 2565 rural and 1165 urban samples. The PPHS covers a wide range of issues including fertility, education, employment, poverty, shocks, nutrition, food insecurity, housing, and well-being. Importantly the third round incorporates "Food Insecurity Experience Scale Survey Module (FIES-SM)". The survey module consists of nine questions designed to evaluate the adequacy of the household access to food. The questions focus on household behaviors and experiences, when they have had faced difficulty in meeting their basic food needs during the last 12 months (see Table 4.1). The FIES Survey module (FIES-SM), which measures the prevalence and severity of individuals/households food insecurity, was also included in the Gallup World Pool (GWP) in 2014 as a part of the FAO's Voice of Hungry (VoH) project. ${ }^{21}$

In this paper our main hypothesis is to test the important determinants of food insecurity using food insecurity experience measurement survey module.

\subsubsection{Dependent variable}

The dependent variables are constructed from the household food security module consisting of 9 questions that are asked from the head of the household (see Table 4.1). We have generated a 10-step food insecurity scale ranging from food secure to severe food insecure households. The ladder coded as 0 is the food secure and 9 as the most food insecure households. The households who answered all the 9 questions as food insecure (affirmed responses) are placed top most food insecure household. While the household who answered all the 9 questions as food secure are placed at the bottom and is considered as food secure households. We have also generated a binary categorical variable of food secure coded as 0 and food insecure coded as 1 . The

\footnotetext{
${ }^{20}$ Districts included in the sample from four provinces are; Dir, Mardan and Lakki Marwat from KP; Attock, Hafizabad, Faisalabad, Vehari, Bahawalpur and Muzaffargarh from Punjab; Larkana, Nawabshah, Mirpur Khas, and Badin from Sindh; and Loralai, Khuzdar, and Gwadar from Baluchistan.

${ }^{21}$ For more information, see http://www.fao.org/in-action/voices-of-the-hungry.
} 
households who answered all the questions as food secure is considered as food secure household, while the households who answered at least one question as food insecure is regarded as food secure household. This classification is termed as moderate food insecure household. Moreover, the severe food insecure household is classified as households who answered at least five questions as food insecure. Similarly, the ten-scale ladder is divided into four categories; high-food-secure scale-0, mild-food-insecure scale (1-3), average-food-insecure (4-6) and highfood-insecure (7-9). The item abbreviation, domains, and mean values of the respective item questions are shown in the last three columns of Table 4.1.

Table 4.1 Household Food Security Module

\begin{tabular}{|c|c|c|c|c|}
\hline & Item Questions/description & $\begin{array}{l}\text { Item } \\
\text { abbreviation }\end{array}$ & Domains & $\begin{array}{l}\text { Mean } \\
\text { values }\end{array}$ \\
\hline 1 & $\begin{array}{l}\text { During the last } 12 \text { months, was your household worried } \\
\text { any time that your food would run out before you had } \\
\text { money to buy more? } 1=\text { yes } 0=\text { No }\end{array}$ & Worried & $\begin{array}{l}\text { Anxiety, } \\
\text { insecurity }\end{array}$ & 0.59 \\
\hline 2 & $\begin{array}{l}\text { During the last } 12 \text { months, the food your household had } \\
\text { did not last, and you did not have enough money to buy } \\
\text { more? } 1 \text { = yes } 0=\text { No }\end{array}$ & $\begin{array}{l}\text { Did not } \\
\text { last/ran out }\end{array}$ & $\begin{array}{l}\text { Anxiety, } \\
\text { insecurity }\end{array}$ & 0.55 \\
\hline 3 & $\begin{array}{l}\text { During the last } 12 \text { months did your household has to eat } \\
\text { the same foods daily because you did not have money to } \\
\text { buy other foods? } 1=\text { yes } 0=\text { No }\end{array}$ & Same food & Quality & 0.53 \\
\hline 4 & $\begin{array}{l}\text { During the last } 12 \text { months, did your or any other adult in } \\
\text { your household cut the size of your meals because you } \\
\text { did not have enough money to buy food? } 1=\text { yes } 0=\text { No }\end{array}$ & Cut size & Quantity & 0.45 \\
\hline 5 & $\begin{array}{l}\text { During the last } 12 \text { months, did you or other member of } \\
\text { your household skip some of daily meals because you } \\
\text { did not have enough money for food? } 1=\text { yes } 0=\text { No }\end{array}$ & Skip & Quantity & 0.21 \\
\hline 6 & $\begin{array}{l}\text { During the last } 12 \text { months, did you ever eat less than you } \\
\text { felt you should because you did not have enough money } \\
\text { money to buy food? } 1=\text { yes } 0=\text { No }\end{array}$ & Eat less & Quantity & 0.30 \\
\hline 7 & $\begin{array}{l}\text { During the last } 12 \text { months, were you or other of your } \\
\text { household ever hungry and did not eat because you did } \\
\text { not have money to buy enough food? } 1=\text { yes } 0=\text { No }\end{array}$ & Hungry & $\begin{array}{l}\text { Consequence } \\
\text { of reduced } \\
\text { intake }\end{array}$ & 0.16 \\
\hline 8 & $\begin{array}{l}\text { During the last } 12 \text { months, did you lose weight because } \\
\text { you did not have enough money to buy food? } \\
1=\text { yes } 0=\text { No }\end{array}$ & Lose weight & $\begin{array}{l}\text { Consequence } \\
\text { of reduced } \\
\text { intake }\end{array}$ & 0.23 \\
\hline 9 & $\begin{array}{l}\text { During the last } 12 \text { months, did you or another adult in } \\
\text { your household ever not eat for a whole day because you } \\
\text { did not have enough money to buy food? } 1=\text { yes } 0=\text { No }\end{array}$ & Whole day & Quantity & 0.12 \\
\hline
\end{tabular}




\subsubsection{Independent variables}

The primary explanatory variables used in the analysis are the common determinants of food insecurity, which consist of individuals, households, and community and district level characteristics. Most of the determinants of the food insecurity are self-explanatory but some of them need explanation (Table 4.2). The important determinants of food insecurity included in the analysis are food inflation, livestock, shocks, and number of terrorist casualties during the 200910 periods. The casualty's variable comes from the Global Terrorism Database (GTD 2016) of the National Consortium for the study of Terrorism and Responses to Terrorism. Hence, the number of death per district during the last two years of reference period is considered as violence. We have taken the death casualties districts wise during the 2009 and 2010 period to measure their impact on households' food insecurity.

\section{Table 4.2 Definition of variables}

\begin{tabular}{|c|c|}
\hline Variables & Definitions \\
\hline \multicolumn{2}{|l|}{ Outcome variables } \\
\hline $\begin{array}{l}\text { Food insecurity experience } \\
\text { scale, }(0-9)\end{array}$ & $\begin{array}{l}\text { Constructed on a } 10 \text { scale ladder from } 0-9 \text {, zero being the food secure } \\
\text { and } 9 \text { being the most food insecure household }\end{array}$ \\
\hline Moderate Food insecure & $\begin{array}{l}\text { Divided into binary category category } 0=\text { food secure, category } 1=\text { food } \\
\text { insecure }(1-9)\end{array}$ \\
\hline Severe food insecure & Divided into two categories, secure (0-5), food insecure (6-9) \\
\hline Four categories: & The food security status divided into four ranges. Category $1=$ High- \\
\hline Category-1, Category-2 & food-secure (0), category $2=$ Mild-food-insecure (1-3), category $3=$ \\
\hline Category-3, Category-4 & Average-food-insecure (4-6), category $4=$ High-food-insecure (7-9) \\
\hline \multicolumn{2}{|l|}{ Explanatory variables } \\
\hline $\begin{array}{l}\text { Log of per capita } \\
\text { consumption }\end{array}$ & $\begin{array}{l}\text { Household natural log of per capita consumption used as proxy for } \\
\text { household per capita income per month }\end{array}$ \\
\hline Household size & Household size is used as a continuous variable \\
\hline Household head age & Included both age and age-squared \\
\hline Household head education & Years of schooling (from no education to 1 \\
\hline HH Head marital status & $\begin{array}{l}\text { We divide marital status of household head into three groups. Group- } 1 \\
\text { married. Group- } 2 \text { is equal to divorced. Group- } 3 \text { is equal to single. }\end{array}$ \\
\hline $\begin{array}{l}\text { Household } \\
\text { employment level }\end{array}$ & $\begin{array}{l}\text { We categorize employment status of the household head into whether } \\
\text { household head is employed, farmer or run his own business. } \\
\text { Yes }=1, \text { No }=0\end{array}$ \\
\hline Agriculture land holdings & $\begin{array}{l}\text { Did the father of the head of household own agriculture land? } \\
\text { Yes }=1, \text { No }=0\end{array}$ \\
\hline Shocks (floods) & $\begin{array}{l}\text { Has your household affected during the last five years from any shocks } \\
\text { such as drought, flood, earthquake, inflation etc.? yes }=1, \text { No }=0\end{array}$ \\
\hline $\begin{array}{l}\text { Agriculture land shocks } \\
\text { interaction }\end{array}$ & $\begin{array}{l}\text { We use interaction term between shocks and household having } \\
\text { agriculture land }\end{array}$ \\
\hline Residence own & $\begin{array}{l}\text { Whether household has its own house? } \\
\text { Yes }=1, \text { No }=0\end{array}$ \\
\hline
\end{tabular}




\begin{tabular}{|c|c|c|}
\hline Variables & & Definitions \\
\hline $\begin{array}{l}\text { Household } \\
\text { (television) }\end{array}$ & asset & Household having television in their houses as an asset $\mathrm{Yes}=1, \mathrm{No}=0$ \\
\hline Violence & & District wise casualties/death during the last two years \\
\hline Household borrowing & & $\begin{array}{l}\text { Have you ever tried to borrow in the past } 12 \text { months and have been } \\
\text { successful? Yes }=1, \text { No }=0\end{array}$ \\
\hline Livestock ownership & & Does your household currently own animals? Yes $=1$, No $=0$ \\
\hline Inflation shock & & $\begin{array}{l}\text { How severely has your household been affected by the recent food price } \\
\text { increase/high overall inflation? Five categories; } 1=\text { not at all affected, } 2 \\
=\text { mildly affected, } 3=\text { moderately affected, } 4=\text { highly affected, } 5= \\
\text { severely affected }\end{array}$ \\
\hline Region & & We have two region, Urban $=1$, Rural $=0$ \\
\hline Provinces & & $\begin{array}{l}\text { Province- } 1=\text { Punjab, province }-2=\text { Sind, province }-3=\mathrm{KP} \text {, province }-4= \\
\text { Baluchistan }\end{array}$ \\
\hline
\end{tabular}

\subsubsection{Descriptive statistics}

Table 4.3 delineates the sampling weight for the overall sample as well as for urban and rural domains. The population for each district is taken from the census 1998. The estimation is done with the sampling weight after cleaning the data. The last three columns from left to right represent the normalized sampling weight of overall, urban, and rural sample respectively.

Table 4.3 Weighting schemes of sample households

\begin{tabular}{|c|c|c|c|c|c|c|}
\hline \multirow[t]{2}{*}{ Districts } & $\begin{array}{l}\text { Total } \\
\text { population }^{\mathrm{a}}\end{array}$ & $\begin{array}{l}\text { Sample } \\
\text { population }^{\mathrm{b}}\end{array}$ & $\begin{array}{l}\text { pweights } \\
{\left[(T P)_{j} /(S P)_{i}\right]}\end{array}$ & $\begin{array}{l}\text { pw- } \\
\text { normalized } \\
{\left[(P W)_{J} / \sum(P W)_{j}\right]}\end{array}$ & $\begin{array}{l}\text { Pwn-Urban } \\
{\left[(P W u)_{J}\right.} \\
\left.\sum(P W u)_{i}\right]\end{array}$ & $\begin{array}{l}\text { pwn-Rural } \\
{\left[(P W r)_{J}\right.} \\
\left.\sum \sum(P W r)_{j}\right]\end{array}$ \\
\hline & $(\mathrm{TP})_{\mathrm{J}}$ & $(\mathrm{SP})_{\mathrm{J}}$ & $(\mathrm{PW})_{\mathrm{J}}$ & $(\mathrm{PWN})_{\mathrm{J}}$ & $(\mathrm{PWNu})_{\mathrm{J}}$ & $(\mathrm{PWNr})_{\mathrm{J}}$ \\
\hline Faisalabad & 5429547 & 3031 & 1791.33 & 0.155 & 0.166 & 0.172 \\
\hline Attock & 1274935 & 1344 & 948.61 & 0.082 & 0.083 & 0.081 \\
\hline Hafizabad & 1136044 & 3648 & 311.41 & 0.026 & 0.041 & 0.023 \\
\hline Vehari & 717649 & 2563 & 280.00 & 0.024 & 0.034 & 0.021 \\
\hline Muzafargarh & 832980 & 1785 & 466.65 & 0.040 & 0.055 & 0.035 \\
\hline Bahawalpur & 2090415 & 1895 & 1103.12 & 0.095 & 0.074 & 0.097 \\
\hline Badin & 2635903 & 1972 & 1336.66 & 0.115 & 0.082 & 0.117 \\
\hline Nawabshah & 2433090 & 2406 & 1011.26 & 0.087 & 0.113 & 0.078 \\
\hline Mirpur Khas & 1071533 & 2237 & 479.00 & 0.041 & 0.054 & 0.036 \\
\hline Larkana & 905935 & 1603 & 565.14 & 0.048 & 0.060 & 0.045 \\
\hline Dir & 1927065 & 2545 & 757.19 & 0.065 & 0.069 & 0.065 \\
\hline Mardan & 1460100 & 1872 & 779.96 & 0.067 & 0.049 & 0.075 \\
\hline Lakki Marwat & 490025 & 543 & 902.44 & 0.078 & 0.032 & 0.090 \\
\hline loralai & 297554 & 1409 & 211.18 & 0.018 & 0.010 & 0.019 \\
\hline Kuzdar & 417466 & 937 & 445.53 & 0.038 & 0.045 & 0.035 \\
\hline
\end{tabular}




\begin{tabular}{lllllll} 
Gwadar & 185497 & 1220 & 152.04 & 0.013 & 0.026 & 0.008 \\
Total & 23305743 & 31010 & 11541.59 & 1 & 1 & 1 \\
\hline
\end{tabular}

Table 4.4 shows descriptive statistics of the ranking of the households from food secure household to the highest food insecure households. Similarly, the generated four categories are high-food-secure (35\%), mild-food-insecure (22\%), average-food-insecure (26\%), and highfood-insecure (17\%). The moderate food insecurity stands at 65 percent at the national level, while the severe food insecurity turns out 23 percent at the national level. The regional and provincial comparison of food insecurity is reported as well.

Table 4.4 Descriptive statistics of Food Insecurity Experience Scale (FIES) in Pakistan

\begin{tabular}{|c|c|c|c|c|c|c|c|c|c|c|}
\hline \multicolumn{11}{|c|}{ Ranking from food secure to the highest food insecure household (\%) } \\
\hline Category & Secure & 1 & 2 & 3 & 4 & 5 & 6 & 7 & 8 & Insecure \\
\hline National & 34.61 & 4.53 & 6.73 & 10.91 & 13.14 & 7.53 & 5.84 & 3.65 & 2.68 & 10.38 \\
\hline Urban & 37.77 & 5.58 & 7.12 & 13.48 & 10.04 & 5.67 & 5.24 & 2.40 & 2.15 & 10.56 \\
\hline Rural & 33.18 & 4.05 & 6.55 & 9.75 & 14.54 & 8.38 & 6.12 & 4.21 & 2.92 & 10.29 \\
\hline Punjab & 31.33 & 4.90 & 6.32 & 11.96 & 11.34 & 8.09 & 6.07 & 4.35 & 3.31 & 12.32 \\
\hline Sindh & 21.54 & 6.15 & 7.78 & 8.78 & 12.31 & 9.32 & 8.96 & 4.93 & 3.80 & 16.38 \\
\hline $\mathrm{KP}$ & 40.77 & 0.87 & 4.70 & 14.46 & 26.83 & 6.97 & 2.61 & 1.57 & 0.35 & 0.87 \\
\hline Baluchistan & 73.33 & 3.81 & 8.33 & 7.62 & 3.57 & 1.43 & 1.19 & 0.24 & 0.48 & 0.00 \\
\hline \multicolumn{11}{|c|}{ Self generated categories } \\
\hline & \multicolumn{5}{|c|}{ Four categories } & \multicolumn{3}{|c|}{ Moderate category } & \multicolumn{2}{|c|}{ Severe category } \\
\hline Category & HFS & MFINS & & AFINS & HFINS & $\mathrm{Sec}$ & & Insecure & Secure & Insecure \\
\hline National & 34.61 & 22.17 & & 26.51 & 16.70 & 34. & & 65.39 & 77.45 & 22.55 \\
\hline Urban & 37.77 & 26.18 & & 20.94 & 15.11 & 37. & & 62.23 & 76.45 & 23.55 \\
\hline Rural & 33.18 & 20.35 & & 29.04 & 17.43 & 33. & & 66.82 & 79.66 & 20.34 \\
\hline Punjab & 31.33 & 23.18 & & 25.51 & 19.99 & 31 . & & 68.67 & 73.94 & 26.06 \\
\hline Sindh & 21.54 & 22.71 & & 30.59 & 25.16 & 21 . & & 78.46 & 65.88 & 34.12 \\
\hline $\mathrm{KP}$ & 40.77 & 20.03 & & 36.41 & 2.79 & 40 . & & 59.23 & 94.60 & 5.40 \\
\hline Baluchistan & 73.33 & 19.76 & & 6.19 & 0.71 & 73. & & 26.67 & 98.10 & 1.90 \\
\hline
\end{tabular}

Note: HFS stands for high-food-secure; MFINS stands for mild-food-insecure

AFINS stands for average-food-insecure; HFINS stands for high-food-insecure

The correlation matrix of food insecurity experience scale consists of nine questions that is asked from the head of the household is shown in Table 4.5. Most of the variables are highly correlated with each other. The Spearman's r correlation among the item scales are quite strong and in the expected direction and it is significant at $\mathrm{p}<0.01$. Particularly the worried-finish $(0.83)$ and hungry -whole day (0.75) are well correlated. 
Table 4.5 Correlation matrix of food insecurity experience scale (FIES)

\begin{tabular}{|l|lllllllll|}
\hline \multicolumn{2}{|c|}{ Worried } & Finish & Same & Cut & Skip & less & Hungry & Loss wt & Whday \\
\hline Worried & 1.000 & & & & & & & & \\
Finish & 0.833 & 1.000 & & & & & & & \\
Same & 0.733 & 0.738 & 1.000 & & & & & & \\
Cut & 0.608 & 0.618 & 0.726 & 1.000 & & & & & \\
Skip & 0.362 & 0.430 & 0.430 & 0.497 & 1.000 & & & & \\
Less & 0.434 & 0.450 & 0.554 & 0.650 & 0.624 & 1.000 & & & \\
Hungry & 0.319 & 0.353 & 0.397 & 0.460 & 0.654 & 0.628 & 1.000 & & \\
Loss wt & 0.335 & 0.402 & 0.437 & 0.512 & 0.579 & 0.660 & 0.686 & 1.000 & \\
Whday & 0.302 & 0.329 & 0.343 & 0.401 & 0.667 & 0.545 & 0.755 & 0.623 & 1.000 \\
\hline
\end{tabular}

Cronbach's alpha is used to assess the reliability or internal consistency of a set of scale items. Cronbach's alpha is one way of measuring the strength of that consistency. This method is a function of the number of items in a test. The coefficients of alpha lie between zero and one. Importantly if all of the scales are entirely independent from one another then alpha $=0$, otherwise, 1. Many methodologists recommend a minimum alpha coefficient between 0.65 and 0.80 and sometime above. Coefficients that are less than 0.5 are usually unacceptable. Moreover, the chance of redundancy of scale items arises when the coefficient is greater than 0.95 . In our analysis, the coefficients lie between 0.89 and 0.90 , which is well in the range set by the previous literature. Table 4.6 shows the results of Cronbach's alpha

Table 4.6 Cronbach's alpha

\begin{tabular}{llllll}
\hline Item & Sign & $\begin{array}{l}\text { Item-test } \\
\text { correlation }\end{array}$ & $\begin{array}{l}\text { Item-rest } \\
\text { correlation }\end{array}$ & $\begin{array}{l}\text { Average inter item } \\
\text { correlation }\end{array}$ & Alpha \\
\hline Worried & + & 0.717 & 0.635 & 0.541 & 0.902 \\
Finish & + & 0.750 & 0.675 & 0.533 & 0.901 \\
Same & + & 0.780 & 0.712 & 0.526 & 0.898 \\
Cut & + & 0.797 & 0.733 & 0.522 & 0.897 \\
Skip & + & 0.763 & 0.691 & 0.530 & 0.900 \\
Less & + & 0.807 & 0.747 & 0.519 & 0.896 \\
Hungry & + & 0.765 & 0.693 & 0.529 & 0.900 \\
Loss wt & + & 0.762 & 0.690 & 0.530 & 0.900 \\
Whday & + & 0.723 & 0.641 & 0.540 & 0.903 \\
Test scale & & & & 0.53 & 0.910 \\
\hline
\end{tabular}

\subsection{Empirical Method}

To analyze the determinants of food insecure households we use an ordered probit model, while a probit model and the linear probability model as robustness check (Greene 2011). 
The latent outcome variable is denoted by FInsecurity $i_{i}^{*}$ (food insecurity) ranging from $-\infty$ to $+\infty$ is estimated to be a linear function of independent explanatory variables as:

$$
\text { FInsecurity }{ }_{i}^{*}=\beta^{i} x_{i}+\epsilon_{i}
$$

Where $\mathrm{i}$ is the individual observation, $\epsilon_{i}$ is the corresponding error with standard normal distribution. We are using ten-scale (ladder) latent response variable ranging from lowest 'food secure' to the highest 'food insecure'. The observed categorical variable FInsecurity ${ }_{i}$ is related to unobserved FInsecurity ${ }_{i}^{*}$ by the threshold model define as:

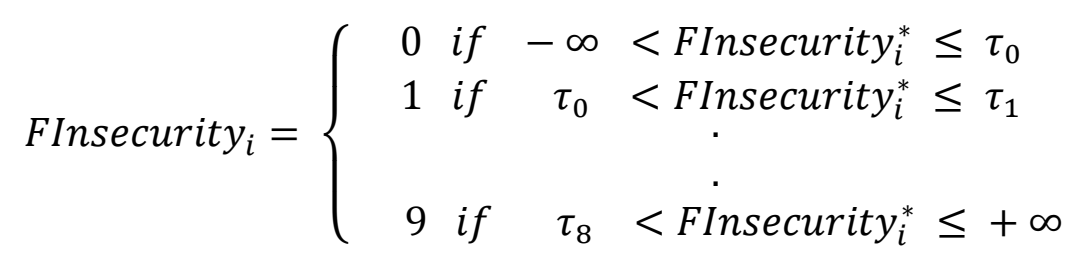

Where, $\tau_{0}$ to $\tau_{8}$ is the threshold points. Given the predictor variables the probability of being observed response variable corresponds to the probability that the latent response variable lies between the corresponding thresholds.

$\operatorname{Pr}($ FInsecurity $=1 \mid \mathrm{X})=\operatorname{Pr}\left(\right.$ FInsecurity $\left.{ }_{i}^{*} \leq \tau_{1}\right)=\Pi_{1}$ $\operatorname{Pr}($ FInsecurity $=2 \mid \mathrm{X})=\operatorname{Pr}\left(\tau_{1}<\right.$ FInsecurity $\left.{ }_{i}^{*} \leq \tau_{2}\right)=\Pi_{2}-\Pi_{1}$

$\operatorname{Pr}($ FInsecurity $=8 \mid \mathrm{X})=\operatorname{Pr}\left(\tau_{7}<\right.$ FInsecurity $\left.{ }_{i}^{*} \leq \tau_{9}\right)=\Pi_{9}-\Pi_{8}$ $\operatorname{Pr}($ FInsecurity $=9 \mid \mathrm{X})=\operatorname{Pr}\left(\tau_{8}<\right.$ FInsecurity $\left.{ }_{i}^{*}\right)=1-\Pi_{9}$

Where $\Pi_{s}$ is the Probit distribution function.

Similarly, the probit model for both moderate and severe food insecurity household is given by:

$\operatorname{Pr}($ FInsecurity $=0 \mid \mathrm{X})=\operatorname{Pr}\left(\right.$ FInsecurity $\left.{ }_{i}^{*} \leq \tau\right)=\Pi$

$\operatorname{Pr}($ FInsecurity $=1 \mid \mathrm{X})=\operatorname{Pr}\left(\right.$ FInsecurity $\left.{ }_{i}^{*}>\tau\right)=1-\Pi$

Where $\tau$ is the threshold value, below the threshold value lies the food secure and above the threshold value lies the food insecure household. Where, "FInsecurity" stands for food insecurity of household.

Table 4.1 provides information about households' demographic characteristics, households' socio-economic characteristics, shocks, and physical insecurity, terrorist activities, food inflation, regional and province dummies to control for regional heterogeneities. The econometric model is specified as follows: 


$$
\begin{aligned}
\text { FInsecurity } & b_{0}+b_{1} \text { consumption }_{i}+b_{2} \text { hh size }_{i}+b_{3} \text { gender }_{i}+b_{4} \text { age }_{i}+b_{5}\left(\text { age }^{2}{ }_{i}\right. \\
& +b_{6} \text { educ }_{i}+b_{7} \text { marital stautus }_{i}+b_{8} \text { employed }_{i}+b_{9} \text { busines }_{i} \\
& +b_{10} \text { farmer }_{i}+b_{11} \text { agri land }_{i}+b_{12} \text { shocks }_{i}+b_{13} \text { agri. shocks }_{i} \\
& +b_{14} \text { assetT }_{i}+b_{15} \text { house condition }_{i}+b_{16} \text { borrowing }_{i}+b_{17} \text { livestock }_{i} \\
& +b_{18} \text { inflation }_{i}+b_{19} \text { physical insecurity }_{i}+b_{20} \text { terrorist casualties }_{i} \\
& +b_{21} \text { region }_{i}+b_{22} \text { province }_{i}+e_{i}
\end{aligned}
$$

Household income plays an important role in the eradication of poverty and hence we expect a positive relationship between income and food security. To this end, we utilize non-parametric test to check the relationship between household income and food security level. Similarly, the household that experienced food inflation is expected to have negative impact on food security. Hence, food inflation and food security link have been established non-parametrically as well. ${ }^{22}$ We also use the linear probability model (LPM) as a robust check. We use heteroskedasticity consistent robust standard error estimates to ward off heteroskedasticity problem. Moreover, the LPM estimates can be biased and inconsistent if the relative proportion of LPM predicted probabilities fall outside the unit interval, if the predicted probabilities fall between 0 and 1 , then the estimates will be unbiased and consistent. In addition, we use the link test for models specification. Link test performs a test for model specification by regressing the response variable on the prediction and the prediction squared. If the model is correctly specified, then the prediction squared would have no explanatory power.

\subsection{Empirical Results and Discussions}

Table 4.7 shows the results of different models of food insecurity. The generated food insecurity ladder from 0-9 results are given in column 2 while the results of four-category are presented in column 3. Column 4 and column 5 show the findings of moderate food insecure and severe food insecure households, respectively. The results of robust check depicted by linear probability model are shown in the last two columns. Along with coefficients, we have also calculated the average marginal effect for both moderate and severe food insecurity.

Household per capita consumption is one of the pivotal determinants of food security (Chiputwa and Qaim 2016). With Higher household income the health, nutrition, and overall well-being of

\footnotetext{
${ }^{22}$ Nonparametric regression provide a useful way to enhance scatter plots to display underlying structure in the data. It plays an important role in diagnostic plots. Used when intrinsic nonlinearity in the data.
} 
the household improves significantly (Barret 2002). The coefficient of consumption is -0.28 and it is statistically significant which indicates as the household consumption per person increases the chances of being food insecure declines. Similarly, a one-unit increase in household per capita consumption leads to 5.3 percentage points and 9.6 percentage point lower probability of experiencing moderate food insecurity and severe food insecurity, respectively.

Importantly to better understand the relationship between household income and food security, the non-parametric Figures are documented (see Figure 4.1, and in appendix Figure 4.3, \& 4.4). The non-parametric result shows that an increase in the household income generally the food security situation of the household improves though none proportionally (unconditional measure). As the household income increases initially, the food insecurity declines quickly, after that when income approximately reaches at $\$ 1.25 /$ day, and then the food security improves but marginally declines. Finally, food security improves with an additional income, until 1.90/day, after that the trend becomes flatten. We could infer the following conclusion from the cubic relationship between income and food security. We have established a non-linear relationship between poverty and food insecurity. We could easily divide households into three categories via food security situation. Below the benchmark of $\$ 1.25$, a day the household food security improves significantly with increasing income. This category of households actually does not care about the quality of food so we expect a strong positive relationship between food security and poverty reduction. However, when the income of the households reaches a certain level, the household start thinking about the quality of the food hence, we could see a marginal increase in food security. Finally, we can see again a relatively increasing trend, which justify that households above the poverty line particularly $\$ 1.90$ per day can afford to buy quality food.

If we look at the Figure 4.1, (Figure $4.3 \& 4.4$ in appendix) food security index still increases when it crosses the poverty threshold $\$ 1.25$ a day. We can conclude here from these interesting findings that even though objectively households are not poor, but using the current method they are poor. Hence, per capita income or consumption is only one of the important determinants of measuring poverty. Therefore, it is not an end in itself but a means to an end. Consequently, due consideration should be given in understanding the prevailing conditions, existing circumstances, education level, level of development of the locality or region while making and implementing any poverty related or food security policies. 
Figure 4. 1 Relationship between food security and poverty

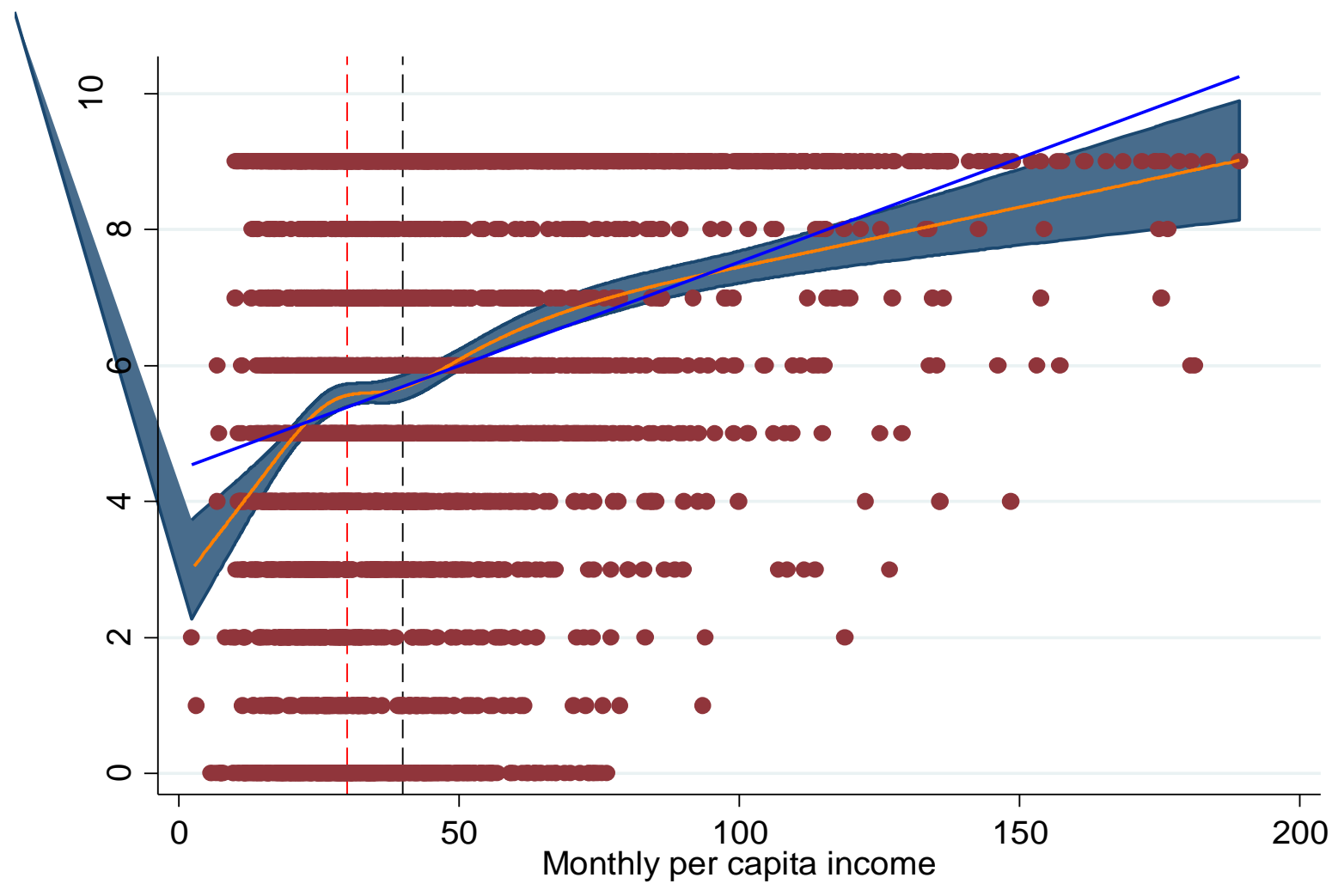

Note: gray area is $95 \%$ confidence interval.

Similarly, our analysis depicts that women being the head of the household are more likely to face food insecure situation. The household headed by female is associated with a 13.3 percentage point high chance of being moderate food insecure compared to male counterpart. Previous researches have also shown that being female are more likely to experience food insecurity (Smith 2017; Mallick and Rafi, 2010; Sraboni et al. 2014; Maitra and Prasada Rao 2017). The reason could be due to women's less access to agriculture activities, livestock, and full utilization of their own land (Maharajan and Joshi 2011). Moreover, female household head lack opportunities in education, employment compared to their male counterpart. However, study based on calorie intake measure indicates that female headed households are less likely to be food insecure on the ground that household headed by female promote better utilization of resources, spend more on food and health care than men (Chiputwa and Qaim 2016).

Generally larger is the number of adults in a household, higher is the chance of household to be food secure (Barret 2002; Smith 2017). It is also plausible that larger households have higher calorie-intake food insecurity as larger households have more mouths to feed (Greer and 
Thorbeke 1986; Kigutha et al. 1998; Maitra and Prasada Rao 2017). Our findings also confirm a significant negative impact of household size (-0.05) on food insecurity. Similarly, the average marginal effect delineates that an increase in household size is associated with 1.1 and 1.9 percentage point lower probability of experiencing moderate and severe food insecurity, respectively. The results are quite contrast to the conventional model-based estimates of food insecurity where the chances of being food insecure exacerbate with the increase in household size (Kigutha et al. 1998; Maitra and Prasada Rao 2017).

The likelihood of experiencing food insecurity falls as the household head age goes up but after certain age the food insecurity again climbs up. This could be due to the dwindling health condition of household head, which retard him from doing physical labor because most of the households' heads are illiterate. However, the results are insignificant. Our results are quite contrast to the findings of (Smith, 2017) where initially the food insecurity increases with age then after a certain period level off with increasing age. Marital status has no significant effect on food insecurity of households. More than 90 percent of household heads are married in the analysis. The distribution of being single and divorced is very few due to which the findings could be insignificant.

Education is one of the key determinants of food security (Barret 2002; Smith 2017). The likelihood of experiencing food insecurity declines with education. This could be due to the generation of income opportunities, employment, self-confidence, and overall well-being. Our findings confirm that an additional year of schooling is associated with -0.09 and -0.05 percentage points' lower probability of experiencing moderate and severe food insecurity, respectively. Pakistan is an agriculture country. Therefore, food security correlates with timely and efficient agriculture production. The result indicates that being farmer increases the chance of food security status of the households. Specifically, having the status of farmer increases the probability of food security by 8.8 percentage points for moderate food insecurity. Likewise, the household that possess agriculture land has higher chance of moderate food secure (5.1 percentage points) while for the case of severe food insecure the result is insignificant. Similarly, the household having their own business as an employment has significant negative impact on severe food insecurity (-3.5 percentage point).

The impact of shocks such as drought, flood, and earthquake is quite often on food security situation of the households. Holden et al. (2004) find that the indirect effects of drought on 
households' welfare are larger than the direct production effects of drought. The immediate impact of drought on crops and livestock are quite severe. We incorporate the shocks experienced by household in our analysis. The magnitude and significance of shocks on both moderate and severe food insecurity is the same. The households witness a shock is associated with 11.4 and 7.1 percentage point higher probability of moderate and severe food insecure, respectively. The drought and the flood critically affect the farmers. Consequently, we use the interaction term between farmers and shocks, indicating that the interaction term correlates with food insecurity positively. The primary reason of high impact of shocks on farmers could be due to severe flood in Pakistan in the year 2010.

We also include households' assets position, ownership of house, livestock, and borrowing in the analysis. The households having their own house have lower chances of being food insecure. Similarly, households that possess an assets have more chance of being food secure. A household with asset is associated with 7.4 percentage points and 10.2 percentage points' lower probability of experiencing moderate and severe food insecurity, respectively. This indicates that household with better economic position have more chance of to be food secure. Household with livestock are expected to be less vulnerable to food insecurity particularly in times of drought (Little et al. 2006). Surprisingly, our results of livestock are not significant. However, livestock is rapidly growing in Pakistan and central to the livelihood of the poor segment of the society. The livestock sector plays an important role in national food security and generates daily cash income for the 8.5 million small farmers and landless families.

One of the policy instruments of food security is to improve the access of household to financial markets (Zeller et al. 1997). In developing countries such as Bangladesh, Ghana and Pakistan credit is severely limited for small farmers, tenants and in particular for women. In Pakistan less than 5 percent of the total borrowings are obtained from formal institutions by poor people (Zeller 2000). A significant portion of the poor are discourage by the strict collateral requirements and high transaction cost. Given the aforementioned difficulties of financial access, our findings confirm the statement. Access to credit increases the probability of experiencing moderate food insecurity and severe food insecurity by 6.6 percentage point and 8.3 percentage points, respectively. In addition, disbursement of right amount of credit at the right time has also been a hurdle to reduce the likelihood of being food insecure. 
Conflicts, disasters, and migration are the main challenges faced by government of Pakistan. Similarly, two-thirds of the world food insecure people live in countries that have experienced civil conflicts in the past decade and conflicts itself are a cause of food insecurity (Hendrix et al. 2013). Terrorist activities, conflicts, and internally displaced people affect household food security and nutrition. The number of death in every district has a significant negative impact on the food security of household. For example, an increase of death casualties is associated with 0.04 and 0.01 percentage point's higher probability of experiencing moderate and severe food insecurity, respectively. Our study confirms the previous study available for Pakistan (Nasir and Rehman 2017).

Furthermore, the country experienced acute price spikes and food shortages during 2007 and 2008 corresponding with the food price spike and volatility in global markets. According to FAO (2009) report, over one billion people went hungry in 2009 from 873 million in 2005-2006. Similarly, Headey (2013) finding shows that global poverty and hunger (food insecurity) increased during food crisis 2008. Hence, food security remains an important public policy objective for nutritional improvement in Pakistan. This analysis incorporates the impact of inflation on food insecurity. The findings show that households with severe food inflation are 45.4 and 13.8 percentage points more likely to experience moderate and severe food insecurity, respectively. Inflation deteriorates the purchasing power of the households leaving the households in the abysmal of food insecurity trap. Importantly, Figure 4.2 explains this negative relationship between food security and inflationary shocks experienced by the households.

Finally, to control for regional heterogeneities, regional and provincial dummies are included in the analysis. The results reveal that the households living in rural areas have more likelihood of experiencing moderate food insecurity. Households living in rural areas have the probability of experiencing moderate food insecurity by 3.8 percentage points higher compared to food secure households. It is also obvious that in the rural areas the availability and access of food is often stringent due to transportation cost and limited income opportunities. 
Figure 4. 2 Relationship between food security and inflationary shocks

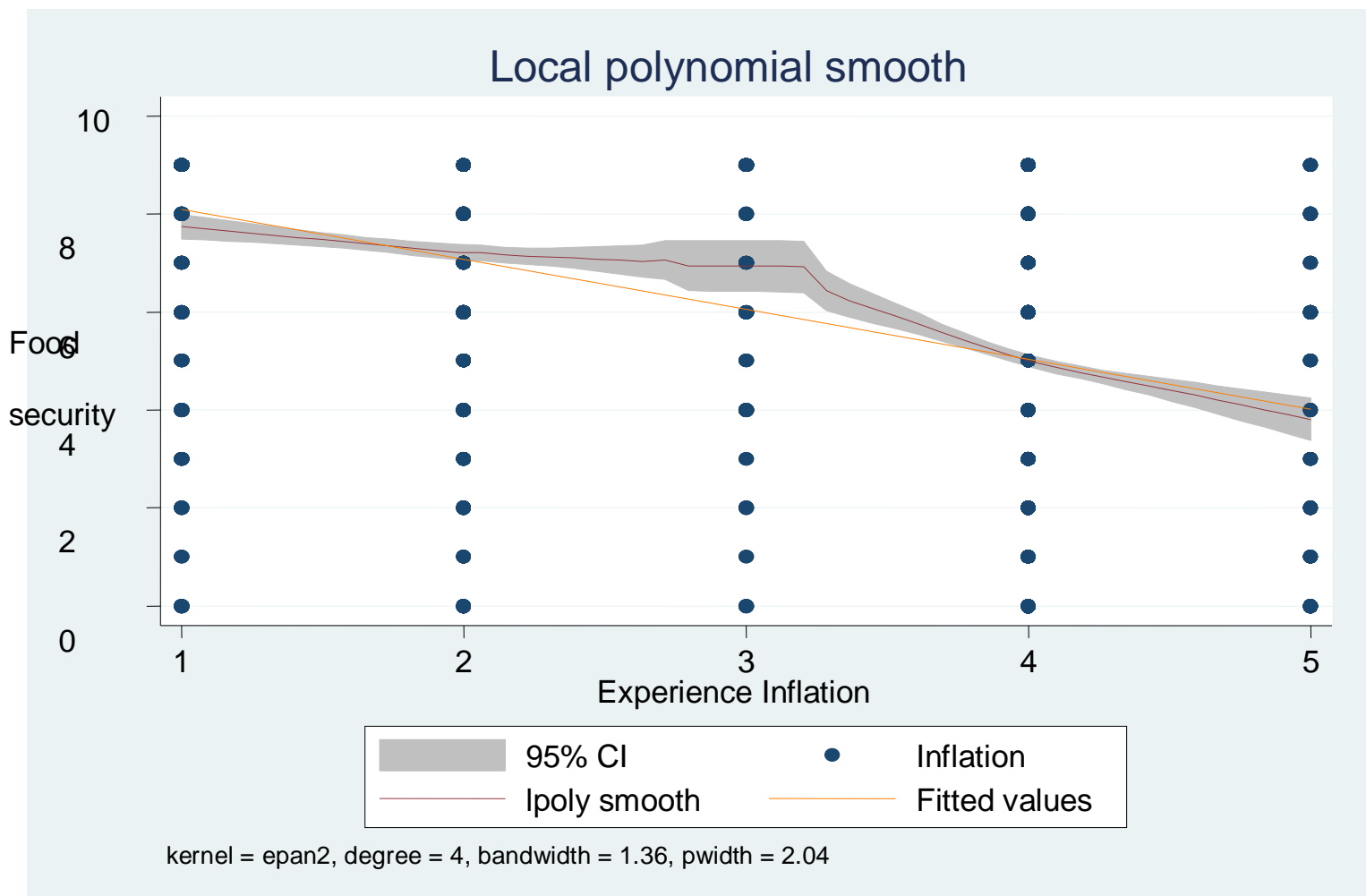

The results of the provinces are quite surprising. Pakistan is a predominantly arid agrarian country where agriculture accounts for 43 percent of labor force. Wheat is the major staple food grain, contributes approximately 45 percent of the daily consumption and important commodity in terms of contribution to national food security (Economic Survey of Pakistan 2015/16). The results indicate that Sindh province is associated with 5.8 and 6.1 percentage point more chances of moderate and severe food insecurity, respectively. Baluchistan province is the least developed province of Pakistan. However, the expected results are opposite. The reason could be due to the relatively richer and urbanized districts of Baluchistan under study compared to other districts in the said province. The results also reveal that the disparity of food insecurity is quite rampant among provinces.

We conclude that the key determinants of the food insecurity are household income, education, household affected by shocks, household assets, violence, and high food prices. In addition, regional and provincial discrepancies exist in terms of food insecurity. Importantly the results of the linear probability model are in line with the aforementioned findings. Similarly, the findings of the four-categories ordered probit model have also the same sign, direction, and magnitude. 
In addition, we test the link test for model specification. The results indicate that the predictionsquared coefficient is not significant. This confirms that all the models included in the analysis are well specified. The diagnostic statistics confirm the overall statistical significance of our models. The cut-off points are shown at the bottom of Table 4.7 where the latent variable is cut to make ten-scale ladder from food secure to food insecure and the four groups of food insecurity. Cut 1 is the estimated cut-off point on the latent variable utilized to differentiate food secure household from food insecure household increasing in ascending order. Cut-point 2 and 3 and above would be interpreted in the same manner. 
Table 4.7 Results of ordered probit model, probit model and linear probability models

\begin{tabular}{|c|c|c|c|c|c|c|c|c|}
\hline \multirow{2}{*}{ Variables } & \multirow{2}{*}{$\begin{array}{l}\text { Model } 1^{\mathrm{a}} \\
\text { Coefficients }\end{array}$} & \multirow{2}{*}{$\begin{array}{l}\text { Model } 2^{\mathrm{b}} \\
\text { Coefficients }\end{array}$} & \multirow{2}{*}{$\begin{array}{l}\text { Model } 3^{\mathrm{c}} \\
\text { Coefficients }\end{array}$} & \multicolumn{3}{|c|}{ Model $4^{\mathrm{d}}$} & \multirow{2}{*}{$\begin{array}{l}\text { Model } 5^{\mathrm{e}} \\
\text { coefficients }\end{array}$} & \multirow{2}{*}{$\begin{array}{l}\text { Model } 6^{\mathrm{f}} \\
\text { coefficients }\end{array}$} \\
\hline & & & & A.M. effect ${ }^{\mathrm{g}}$ & Coefficients & A.M. effect & & \\
\hline \multicolumn{9}{|c|}{ Per capita household consumption } \\
\hline Consumption & $\begin{array}{l}-0.283 * * * \\
(0.035)\end{array}$ & $\begin{array}{l}-0.283 * * * \\
(0.036)\end{array}$ & $\begin{array}{l}-0.205 * * * \\
(0.046)\end{array}$ & $\begin{array}{l}-0.053 * * * \\
(0.012)\end{array}$ & $\begin{array}{l}-0.446 * * * \\
(0.055)\end{array}$ & $\begin{array}{l}-0.096 * * * \\
(0.001)\end{array}$ & $\begin{array}{l}-0.053 * * * \\
(0.012)\end{array}$ & $\begin{array}{l}-0.083 * * * \\
(0.010)\end{array}$ \\
\hline \multicolumn{9}{|c|}{ Gender of household head (Reference category female) } \\
\hline Male & $\begin{array}{l}-0.366 * * * \\
(0.135)\end{array}$ & $\begin{array}{l}-0.435 * * * \\
(0.141)\end{array}$ & $\begin{array}{l}-0.509 * * \\
(0.200)\end{array}$ & $\begin{array}{l}-0.133 * * \\
(0.052)\end{array}$ & $\begin{array}{l}-0.191 \\
(0.186)\end{array}$ & $\begin{array}{l}-0.041 \\
(0.039)\end{array}$ & $\begin{array}{l}-0.114 * * \\
(0.047)\end{array}$ & $\begin{array}{l}-0.056 \\
(0.044)\end{array}$ \\
\hline \multicolumn{9}{|c|}{ Household size (continuous variable) } \\
\hline Household size & $\begin{array}{l}-0.059 * * * \\
(0.009)\end{array}$ & $\begin{array}{l}-0.056 * * * \\
(0.009)\end{array}$ & $\begin{array}{l}-0.043 * * * \\
(0.011)\end{array}$ & $\begin{array}{l}-0.011 * * * \\
(0.003)\end{array}$ & $\begin{array}{l}-0.090 * * * \\
(0.014)\end{array}$ & $\begin{array}{l}-0.019 * * * \\
(0.003)\end{array}$ & $\begin{array}{l}-0.011 * * * \\
(0.003)\end{array}$ & $\begin{array}{l}-0.014 * * * \\
(0.002)\end{array}$ \\
\hline \multicolumn{9}{|c|}{ Education of household head (continuous variable) } \\
\hline Years of schooling & $\begin{array}{l}-0.034 * * * \\
(0.004)\end{array}$ & $\begin{array}{l}-0.035 * * * \\
(0.005)\end{array}$ & $\begin{array}{l}-0.035 * * * \\
(0.006)\end{array}$ & $\begin{array}{l}-0.009 * * * \\
(0.001)\end{array}$ & $\begin{array}{l}-0.025 * * * \\
(0.007)\end{array}$ & $\begin{array}{l}-0.005^{* * *} * \\
(0.001)\end{array}$ & $\begin{array}{l}-0.010 * * * \\
(0.002)\end{array}$ & $\begin{array}{l}-0.005 * * * \\
(0.001)\end{array}$ \\
\hline \multicolumn{9}{|c|}{ Age of household head (continuous variable) } \\
\hline Age & $\begin{array}{l}-0.007 \\
(0.008)\end{array}$ & $\begin{array}{l}-0.008 \\
(0.008)\end{array}$ & $\begin{array}{l}-0.006 \\
(0.012)\end{array}$ & $\begin{array}{l}-0.001 \\
(0.002)\end{array}$ & $\begin{array}{l}-0.012 \\
(0.011)\end{array}$ & $\begin{array}{l}-0.002 \\
(0.002)\end{array}$ & $\begin{array}{l}-0.001 \\
(0.002)\end{array}$ & $\begin{array}{l}-0.004 * \\
(0.003)\end{array}$ \\
\hline Age square & $\begin{array}{l}0.000 \\
(0.000)\end{array}$ & $\begin{array}{l}0.000 \\
(0.000)\end{array}$ & $\begin{array}{l}0.000 \\
(0.0001)\end{array}$ & $\begin{array}{l}0.000 \\
(0.000)\end{array}$ & $\begin{array}{l}0.0001 \\
(0.0001)\end{array}$ & $\begin{array}{l}0.000 \\
(0.000)\end{array}$ & $\begin{array}{l}3.21 \mathrm{e}-06 \\
(2.90 \mathrm{e}-05)\end{array}$ & $\begin{array}{l}4.30 \mathrm{e}-05^{*} \\
(2.59 \mathrm{e}-05)\end{array}$ \\
\hline \multicolumn{9}{|c|}{ Marital status (Reference category married) } \\
\hline Divorced & $\begin{array}{l}-0.081 \\
(0.093)\end{array}$ & $\begin{array}{l}-0.091 \\
(0.095)\end{array}$ & $\begin{array}{l}-0.001 \\
(0.129)\end{array}$ & $\begin{array}{l}-0.0003 \\
(0.033)\end{array}$ & $\begin{array}{l}-0.114 \\
(0.144)\end{array}$ & $\begin{array}{l}-0.023 \\
(0.029)\end{array}$ & $\begin{array}{l}0.005 \\
(0.034)\end{array}$ & $\begin{array}{l}-0.037 \\
(0.032)\end{array}$ \\
\hline Single & $\begin{array}{l}0.106 \\
(0.167)\end{array}$ & $\begin{array}{l}0.101 \\
(0.180)\end{array}$ & $\begin{array}{l}0.0640 \\
(0.228)\end{array}$ & $\begin{array}{l}0.016 \\
(0.058)\end{array}$ & $\begin{array}{l}0.251 \\
(0.247)\end{array}$ & $\begin{array}{l}0.058 \\
(0.060)\end{array}$ & $\begin{array}{l}0.019 \\
(0.051)\end{array}$ & $\begin{array}{l}0.052 \\
(0.065)\end{array}$ \\
\hline \multicolumn{9}{|c|}{ Employment status (Reference category No) } \\
\hline Yes & $\begin{array}{l}-0.020 \\
(0.071)\end{array}$ & $\begin{array}{l}-0.029 \\
(0.073)\end{array}$ & $\begin{array}{l}0.0330 \\
(0.096)\end{array}$ & $\begin{array}{l}0.008 \\
(0.025)\end{array}$ & $\begin{array}{l}-0.120 \\
(0.098)\end{array}$ & $\begin{array}{l}-0.025 \\
(0.021)\end{array}$ & $\begin{array}{l}0.006 \\
(0.026)\end{array}$ & $\begin{array}{l}-0.020 \\
(0.022)\end{array}$ \\
\hline \multicolumn{9}{|c|}{ Own residence of household (Reference category No) } \\
\hline Yes & $\begin{array}{l}-0.068 \\
(0.052)\end{array}$ & $\begin{array}{l}-0.052 \\
(0.054)\end{array}$ & $\begin{array}{l}-0.002 \\
(0.077)\end{array}$ & $\begin{array}{l}-0.0007 \\
(0.020)\end{array}$ & $\begin{array}{l}-0.105 \\
(0.070)\end{array}$ & $\begin{array}{l}-0.022 \\
(0.015)\end{array}$ & $\begin{array}{l}-0.003 \\
(0.019)\end{array}$ & $\begin{array}{l}-0.032 * \\
(0.017)\end{array}$ \\
\hline \multicolumn{9}{|c|}{ Asset of household (television) (Reference category No) } \\
\hline Yes & $\begin{array}{l}-0.403 * * * \\
(0.051)\end{array}$ & $\begin{array}{l}-0.378 * * * \\
(0.052)\end{array}$ & $\begin{array}{l}-0.282 * * * \\
(0.070)\end{array}$ & $\begin{array}{l}-0.074 * * * \\
(0.018)\end{array}$ & $\begin{array}{l}-0.476 * * * \\
(0.068)\end{array}$ & $\begin{array}{l}-0.102 * * * \\
(0.014)\end{array}$ & $\begin{array}{l}-0.079 * * * \\
(0.018)\end{array}$ & $\begin{array}{l}-0.125 * * * \\
(0.015)\end{array}$ \\
\hline $\begin{array}{l}\text { Occupation: house } \\
\text { Yes }\end{array}$ & $\begin{array}{l}\text { ld head is far } \\
-0.313 * * *\end{array}$ & $\begin{array}{c}\text { er (Reference } \\
-0.309 * * *\end{array}$ & $\begin{array}{l}\text { ategory No) } \\
-0.338 * * *\end{array}$ & $-0.088 * * *$ & $-0.238 * * *$ & -0.051 & $-0.085 * * *$ & $-0.053 * * *$ \\
\hline
\end{tabular}




\begin{tabular}{|c|c|c|c|c|c|c|c|c|}
\hline \multirow{2}{*}{ Variables } & Model $1^{\mathrm{a}}$ & Model $2^{b}$ & Model $3^{\mathrm{c}}$ & \multicolumn{3}{|c|}{ Model $4^{\mathrm{d}}$} & \multirow{2}{*}{$\frac{\text { Model } 5^{\mathrm{e}}}{\text { coefficients }}$} & \multirow{2}{*}{$\begin{array}{l}{\text { Model } 6^{\mathrm{f}}}^{\text {coefficients }} \\
\end{array}$} \\
\hline & Coefficients & Coefficients & Coefficients & A.M. effect ${ }^{g}$ & Coefficients & A.M. effect & & \\
\hline & $(0.058)$ & $(0.059)$ & $(0.080)$ & $(0.021)$ & $(0.084)$ & $(0.018)$ & $(0.021)$ & $(0.019)$ \\
\hline \multicolumn{9}{|c|}{ Own business (Reference category No) } \\
\hline \multirow[t]{2}{*}{ Yes } & -0.094 & -0.064 & -0.024 & -0.006 & $-0.164 *$ & $-0.035 *$ & -0.006 & $-0.038 * *$ \\
\hline & $(0.063)$ & $(0.066)$ & $(0.089)$ & $(0.023)$ & $(0.098)$ & $(0.021)$ & $(0.025)$ & $(0.019)$ \\
\hline \multicolumn{9}{|c|}{ Household experience shocks (Reference category No) } \\
\hline \multirow[t]{2}{*}{ Yes } & $0.335^{* * *}$ & $0.327 * * *$ & $0.328 * * *$ & $0.114 * * *$ & $0.235^{*}$ & $0.071 * * *$ & $0.109 * * *$ & $0.045^{*}$ \\
\hline & $(0.091)$ & $(0.090)$ & $(0.105)$ & $(0.025)$ & $(0.124)$ & $(0.018)$ & $(0.031)$ & $(0.025)$ \\
\hline \multicolumn{9}{|c|}{ Household agriculture land (Reference category No) } \\
\hline \multirow[t]{2}{*}{ Yes } & $-0.344 * * *$ & $-0.340 * * *$ & $-0.352 * * *$ & $-0.051 * * *$ & $-0.463 * *$ & -0.017 & $-0.093 * *$ & -0.035 \\
\hline & $(0.124)$ & $(0.125)$ & $(0.135)$ & $(0.018)$ & $(0.200)$ & $(0.015)$ & $(0.036)$ & $(0.023)$ \\
\hline \multicolumn{9}{|l|}{ Interaction term } \\
\hline \multirow[t]{2}{*}{ Shock-.agri. land } & $0.261 * *$ & $0.241 *$ & 0.187 & & $0.410 * *$ & & 0.050 & 0.0216 \\
\hline & $(0.129)$ & $(0.130)$ & $(0.144)$ & & $(0.206)$ & & $(0.039)$ & $(0.0261)$ \\
\hline \multicolumn{9}{|c|}{ Household Borrowing (Reference category No) } \\
\hline \multirow[t]{2}{*}{ Yes } & $0.248 * * *$ & $0.254 * * *$ & $0.369 * * *$ & $0.097 * * *$ & $0.144 * *$ & $0.031 * *$ & $0.093 * * *$ & $0.032 *$ \\
\hline & $(0.045)$ & $(0.047)$ & $(0.067)$ & 0.017 & $(0.063)$ & 0.013 & $(0.016)$ & $(0.016)$ \\
\hline \multicolumn{9}{|c|}{ Household Livestock (Reference category No) } \\
\hline \multirow[t]{2}{*}{ Yes } & 0.078 & 0.0817 & 0.116 & 0.030 & -0.047 & -0.010 & 0.037 & -0.002 \\
\hline & $(0.063)$ & $(0.066)$ & $(0.085)$ & 0.023 & $(0.102)$ & 0.021 & $(0.024)$ & $(0.022)$ \\
\hline \multicolumn{9}{|c|}{ District-wise terrorist activities ( numbers of death) } \\
\hline \multirow[t]{2}{*}{ Total death } & $0.004 * * *$ & $0.004 * * *$ & $0.003 * * *$ & $0.0009 * * *$ & $0.004 * * *$ & $0.001 * * *$ & $0.001 * * *$ & $0.0006 * * *$ \\
\hline & $(0.0005)$ & $(0.0005)$ & $(0.0006)$ & 0.0001 & $(0.0008)$ & 0.0001 & $(0.0002)$ & $(0.0001)$ \\
\hline \multicolumn{9}{|c|}{ Inflation shock (Reference category not at all affected) } \\
\hline \multirow[t]{2}{*}{ Mildly affected } & $0.180^{*}$ & $0.197 * *$ & $0.248 * *$ & $0.082 * *$ & -0.157 & -0.026 & $0.069 * *$ & $-0.073 * * *$ \\
\hline & $(0.0924)$ & $(0.0939)$ & $(0.104)$ & 0.034 & $(0.138)$ & 0.023 & $(0.032)$ & $(0.021)$ \\
\hline \multicolumn{9}{|l|}{ Moderately } \\
\hline \multirow[t]{2}{*}{ affected } & $0.334 * *$ & $0.355^{* *}$ & $0.493 * * *$ & $0.164 * * *$ & -0.121 & -0.020 & $0.161 * * *$ & $-0.092 * *$ \\
\hline & $(0.141)$ & $(0.146)$ & $(0.166)$ & $(0.054)$ & $(0.234)$ & $(0.038)$ & $(0.055)$ & $(0.042)$ \\
\hline \multirow[t]{2}{*}{ Highly afected } & $0.881 * * *$ & $0.912 * * *$ & $1.073 * * *$ & $0.335 * * *$ & $0.440 * * *$ & $0.093 * * *$ & $0.335^{* * *} *$ & $0.043 *$ \\
\hline & $(0.0895)$ & $(0.091)$ & $(0.107)$ & $(0.035)$ & $(0.128)$ & $(0.024)$ & $(0.032)$ & $(0.024)$ \\
\hline \multirow[t]{2}{*}{ Severly affected } & $1.076^{* * *}$ & $1.101 * * *$ & $1.626^{* * *}$ & $0.454 * * *$ & $0.620 * * *$ & $0.138 * * *$ & $0.413 * * *$ & $0.128 * * *$ \\
\hline & $(0.122)$ & $(0.124)$ & $(0.185)$ & $(0.042)$ & $(0.166)$ & $(0.037)$ & $(0.037)$ & $(0.043)$ \\
\hline \multicolumn{9}{|c|}{ Region (Reference category rural) } \\
\hline Urban & $-0.127 * *$ & $-0.170 * * *$ & $-0.212 * * *$ & $-0.058 * *$ & 0.008 & 0.002 & $-0.053 * * *$ & -0.0005 \\
\hline
\end{tabular}




\begin{tabular}{|c|c|c|c|c|c|c|c|c|}
\hline \multirow{2}{*}{ Variables } & \multirow{2}{*}{$\begin{array}{l}\text { Model } 1^{\mathrm{a}} \\
\text { Coefficients }\end{array}$} & \multirow{2}{*}{$\frac{\text { Model } 2^{\mathrm{b}}}{\text { Coefficients }}$} & \multicolumn{2}{|l|}{ Model $3^{\mathrm{c}}$} & \multicolumn{2}{|l|}{ Model $4^{\mathrm{d}}$} & \multirow{2}{*}{$\begin{array}{l}\text { Model } 5^{\mathrm{e}} \\
\text { coefficients }\end{array}$} & \multirow{2}{*}{$\frac{\text { Model } 6^{\mathrm{f}}}{\text { coefficients }}$} \\
\hline & & & Coefficients & A.M. effect ${ }^{\mathrm{g}}$ & Coefficients & A.M. effect & & \\
\hline & $(0.052)$ & $(0.054)$ & $(0.073)$ & $(0.019)$ & $(0.071)$ & $(0.015)$ & $(0.019)$ & $(0.015)$ \\
\hline \multicolumn{9}{|c|}{ Provinces (Reference category Punjab) } \\
\hline \multirow[t]{2}{*}{ Sindh } & $0.220 * * *$ & $0.219 * * *$ & $0.224 * * *$ & $0.058 * *$ & $0.238 * * *$ & $0.061 * * *$ & $0.063 * * *$ & $0.048 * * *$ \\
\hline & $(0.051)$ & $(0.052)$ & $(0.069)$ & $(0.018)$ & $(0.068)$ & $(0.017)$ & $(0.017)$ & $(0.018)$ \\
\hline \multirow[t]{2}{*}{ KP } & 0.083 & 0.097 & 0.126 & 0.033 & $-0.360 * * *$ & $-0.076 * * *$ & 0.039 & $-0.088 * * *$ \\
\hline & $(0.068)$ & $(0.070)$ & $(0.092)$ & $(0.024)$ & $(0.127)$ & $(0.024)$ & $(0.026)$ & $(0.018)$ \\
\hline \multirow[t]{2}{*}{ Baluchistan } & $-2.235 * * *$ & $-2.197 * * *$ & $-2.055 * * *$ & $-0.551 * * *$ & $-2.204 * * *$ & $-0.215 * * *$ & $-0.612 * * *$ & $-0.282 * * *$ \\
\hline & $(0.138)$ & $(0.142)$ & $(0.152)$ & $(0.025)$ & $(0.285)$ & $(0.011)$ & $(0.032)$ & $(0.022)$ \\
\hline \multirow[t]{2}{*}{ Constant } & & & $2.091 * * *$ & & $3.592 * * *$ & & $0.982 * * *$ & $1.223 * * *$ \\
\hline & & & $(0.543)$ & & $(0.609)$ & & $(0.146)$ & $(0.124)$ \\
\hline Cut1 & $-3.020 * * *$ & $-3.104 * * *$ & & & & & & \\
\hline Cut2 & $-2.848 * * *$ & $-2.314 * * *$ & & & & & & \\
\hline Cut3 & $-2.621 * * *$ & $-1.218 * * *$ & & & & & & \\
\hline Cut4 & $-2.228 * * *$ & & & & & & & \\
\hline Cut5 & $-1.725 * * *$ & & & & & & & \\
\hline Cut6 & $-1.405 * * *$ & & & & & & & \\
\hline Cut7 & $-1.123 * * *$ & & & & & & & \\
\hline Cut8 & $-0.928 * *$ & & & & & & & \\
\hline Cut9 & $-0.776^{*}$ & & & & & & & \\
\hline \multicolumn{9}{|l|}{ Diagnostic Test } \\
\hline Wald chi2(27) & 1507.15 & 1395.97 & 932.08 & & 584.46 & & & \\
\hline Prob > chi 2 & 0.000 & 0.000 & 0.000 & & 0.000 & & & \\
\hline Pseudo R2 & 0.12 & 0.17 & 0.27 & & 0.24 & & & \\
\hline \multicolumn{9}{|l|}{$\log$} \\
\hline pseudolikelihood & -381.445 & -241.510 & -101.698 & & -83.836 & & & \\
\hline $\mathrm{F}(27,3702)$ & & & & & & & 99.97 & 36.35 \\
\hline Prob $>F$ & & & & & & & 0.000 & 0.000 \\
\hline R-squared & & & & & & & 0.322 & 0.198 \\
\hline Root MSE & & & & & & & .393 & .361 \\
\hline \multicolumn{9}{|c|}{ Link test (Model Specification Test) } \\
\hline _hat & $1.070 * * *$ & $1.113 * * *$ & $1.002 * * *$ & & $1.059 * * *$ & & $0.989 * * *$ & 0.346 \\
\hline & $(0.134)$ & $(0.146)$ & $(0.039)$ & & $(0.082)$ & & $(0.070)$ & $(0.045)$ \\
\hline _hatsq & 0.013 & 0.020 & -0.004 & & 0.036 & & 0.009 & $1.676 * *$ \\
\hline & $(0.025)$ & $(0.026)$ & $(0.039)$ & & $(0.043)$ & & $(0.062)$ & $(0.138)$ \\
\hline
\end{tabular}


What Determines Food (in)security in Pakistan? New Evidence...

\begin{tabular}{|c|c|c|c|c|c|c|c|c|}
\hline Models & Model $1^{\mathrm{a}}$ & Model $2^{b}$ & Model $3^{\mathrm{c}}$ & & Model $4^{\mathrm{d}}$ & & Model $5^{\mathrm{e}}$ & Model $6^{\mathrm{f}}$ \\
\hline Variables & Coefficients & Coefficients & Coefficients & A.M. effect ${ }^{g}$ & Coefficients & A.M. effect & coefficients & coefficients \\
\hline Observations & 3730 & 3730 & 3730 & & 3730 & & 3730 & 3730 \\
\hline
\end{tabular}

*** $\mathrm{p}<0.01, * * \mathrm{p}<0.05, * \mathrm{p}<0.1$

$\mathrm{a}=$ Model 1: ordered probit model scale-1 to scale-9 (scale-1 is food secure and scale-9 is most food insecure)

$\mathrm{b}=$ Model 2: Ordered Probit Model (4 categories, category $1=$ high-food-secure, category $2=$ mild-food-insecure,

category 3 = average-food-insecure, category 4 = high-food-insecure)

$\mathrm{c}=$ Model 3: Probit Model $(0=$ food secure, $1-9=$ Moderate food insecure $)$

$\mathrm{d}=$ Model 4: Probit Model (0-5 = food secure, 6-9 = Severe food insecure)

e $=$ Model 5: Linear Probability Model $(0=$ food secure, $1-9=$ Moderate food insecure $)$

$\mathrm{f}=$ Model 6: Linear Probability Model (0-5 = food secure, 6-9 = Severe food insecure)

$\mathrm{g}=$ average marginal effect 


\subsection{Conclusion and Policy Recommendations}

The current study examines the determinants of household food insecurity in Pakistan. For this purpose, the household head is asked about multidimensional nature of household food insecurity situation. For empirical purpose and concrete set up the generated food insecurity index ranging from food secure to food insecure households along with linear probability model are analyzed. The results indicate that household per capita consumption, household education, gender, household size, household assets, borrowing, shocks, violence, and high inflation are the important determinants of food insecurity. Importantly household income and food security are positively related while negative trend between food security and inflationary shocks. This study varies in some determinants when we compared it with conventional measure of food insecurity. Specifically, the study finds that with increasing household size, the likelihood of food insecurity decreases. Similarly, the household headed by female is more food insecure. The incidence of shocks on agriculture land is severe, which in turn affect household food security. Moreover, as the terrorist activities climb up district wise the probability of food insecurity also increases.

From policy perspective, our findings reveal the significance of the determinants that constitute the mainstream of development economics. Importantly an increase in the household income is inevitable particularly of the lower income brackets, which are highly vulnerable to food insecurity. Therefore, increasing productivity of major crops by diverting saved natural resources for the production of other high value crops through innovative agriculture scientific method is necessary. The short-term solution would be the provision of national food safety net program. The long run solution lies in the economic growth and equitable distribution of land and resources, which not only ensure higher income but also create opportunities for the poor to gain access to nutrition, health, education, and employment. The private sector should be given incentives to invest in the livestock sector.

Achieving food security remains a critical objective of development in Pakistan. The national average yields of almost all crops are low, coupled with low public sector investment in Pakistan's agricultural R\& D, which is only 0.18 percent of agriculture GDP. This should be at least at par with the neighboring countries. Similarly, the importance of agribusiness should be streamline. Food stability must be present at all times in terms of availability, access, and utilization. Hence, sustainable agriculture by efficient utilization and management of natural resources and market regulation to achieve transparency could be ensured to maximize stability 
of food, social, economic, and environmental benefits. The results find that farmers are compelled to avail credit from informal sources at very high cost. Creation of opportunities and promotion of low cost microfinance particularly among rural population should be the priority from the policy perspective. Importantly education is critical for the farmers to adopt improved farming practices. The government need to take measures to improve the livelihood of farmers, particularly changes in its production system. Conflicts, natural disasters, and migration are critical for food security and nutrition hence collaboration with national and international agencies in conflict affected and disaster hit areas should be encouraged. 


\subsection{References}

Abdullah, Zhou, D., Shah, T., Ali, S., Ahmad, W., Din, I.U., Ilyas, A., (2017). Factors affecting household food security in rural northern hinterland of Pakistan. J. Saudi Soc. Agric. Sci. doi:10.1016/j. jssas. 2017.05.003

Ahmad, F., (2009). Food security in Pakistan. Pak. J. Agric. Sci. 46, 83-89.

Asghar, Z., \& Muhammad, A., (2013). Socio-economic Determinants of Household Food Insecurity in Pakistan, https://mpra.ub.uni-muenchen.de/21510/

Baig-Ansari, N., Rahbar, M. H., Bhutta, Z. A., Badruddin, S. H., (2006). Child's Gender and Household Food Insecurity are Associated with Stunting among Young Pakistani Children Residing in Urban Squatter Settlements. Food Nutr. Bull. 27, 114-127. doi: $10.1177 / 156482650602700203$

Barrett, C. B. (2010). Measuring food insecurity. Science, 327(5967), 825-828.

Bashir, M. K., Schilizzi, S., (2015). Food security policy assessment in the Punjab, Pakistan: effectiveness, distortions and their perceptions. Food Secur. 7, 1071-1089.

Bashir, M. K., Schilizzi, S., Pandit, R., (2013). Impact of socio-economic characteristics of rural households on food security: the case of the Punjab, Pakistan. JAPS J. Anim. Plant Sci. 23, 611-618.

Chiputwa, B., Qaim, M. (2016). Sustainability standards, gender, and nutrition among smallholder farmers in Uganda. The Journal of Development Studies, 52(9), 12411257.

Coates, J., Webb, P., \& Houser, R. (2003). Measuring food insecurity: going beyond indicators of income and anthropometry. Food and Nutrition Technical Assistance Project, Academy for Educational Development.

Coates, J., Wilde, P. E., Webb, P., Rogers, B. L., Houser, R. F., (2006). Comparison of a Qualitative and a Quantitative Approach to Developing a Household Food Insecurity Scale for Bangladesh. J. Nutr. 136, 1420S-1430S.

FAO. (2009). The state of Food Insecurity in the World. Economic crisis-impacts and lession learned. Rome: Food and Agriculture Organization of the United Nations. http://www.fao.org/

FAO. (2013). The multiple dimensions of food security. Food and Agriculture Organization of the United Nations. http://www.fao.org/ 
Frongillo, E. A., Nanama, S., (2006). Development and Validation of an Experience-Based Measure of Household Food Insecurity within and across Seasons in Northern Burkina Faso. J. Nutr. 136, 1409S-1419S.

Gazdar, H., \& Mallah, H. B., (2013). Inflation and Food Security in Pakistan: Impact and Coping Strategies. IDS Bull. 44, 31-37. doi:10.1111/1759-5436.12028

Government of Pakistan (2014). Economic Survey 2013-14. Ministry of Finance. Islamabad.

Greene, W. H. (2011). Econometric Analysis (7 $7^{\text {th }}$ edition). ISBN-13, 978-0131395381.

Greer, J., and Thorbecke, E. (1986). A methodology for measuring food poverty applied to Kenya. Journal of Development Economics, 24(1), 59-74.

Headey, D. D. (2013). The impact of the global food crisis on self-assessed food security. The World Bank Economic Review, 27(1), 1-27.

Hendrix, C., and Brinkman, H. J. (2013). Food insecurity and conflict dynamics: Causal linkages and complex feedbacks. Stability: International Journal of Security and Development, 2(2).

Holden, S., Shiferaw, B. (2004). Land degradation, drought and food security in a lessfavoured area in the Ethiopian highlands: a bio-economic model with market imperfections. Agricultural Economics, 30(1), 31-49.

International Food Policy Research Institute (IFPRI) 2016. Global Nutrition Report 2016: From Promise to Impact: Ending Malnutrition by 2030. Washington, DC.

Khan, M. A., \& Shah, S. A. A., (2011). Food Insecurity in Pakistan: Causes and Policy Response. J. Agric. Environ. Ethics, 24, 493-509. doi:10.1007/s10806-010-9274-2

Kigutha, H. N., Van Staveren, W. A., Veerman, W., \& Hautvast, J. G. (1998). Effects of seasonality on household food availability among smallholder rural households in Kenya: Impact of land size, household size and composition. Ecology of food and nutrition, 37(1), 73-100.

Klasen, S. (2008). Poverty, undernutrition, and child mortality: Some inter-regional puzzles and their implications for research and policy. The Journal of Economic Inequality, 6(1), 89-115.

Mies, M. (1982). The lace makers of Narsapur: Indian housewives produce for the world market. Zed Books.

Little, P. D., Stone, M. P., Mogues, T., Castro, A. P., \& Negatu, W. (2006). 'Moving in place': Drought and poverty dynamics in South Wollo, Ethiopia. The Journal of Development Studies, 42(2), 200-225. 
Maharjan, K. L., \& Joshi, N. P. (2011). Determinants of household food security in Nepal: A binary logistic regression analysis. Journal of Mountain Science, 8(3), 403-413.

Mahmood, S., Tabassum, A., Khan, S. A., Jabeen, N., (2014). An Investigation of Determinants of Food Security in Rural Areas of Faisalabad, Pakistan. Mediterr. $J$. Soc. Sci. 5, 676.

Mallick, D., \& Rafi, M. (2010). Are female-headed households more food insecure? Evidence from Bangladesh. World development, 38(4), 593-605.

Maitra, C., \& Prasada Rao, D. S. (2017). An Empirical Investigation into Measurement and Determinants of Food Security. The Journal of Development Studies, 1-22.

Masset, E. (2011). A review of hunger indices and methods to monitor country commitment to Figurehting hunger. Food policy, 36, S102-S108.

National Consortium for the Study of Terrorism and Responses to Terrorism, A Center of Excellence of the U.S. Department of Homeland Security. University of Maryland, College Park, MD 20740, USA 301.405.6600

Nasir, M., \& Rehman, F. U. (2017). Correlates of Perceived Insecurity: Evidence from Pakistan. Defence and Peace Economics, 1-17.

Nord, M., 2012. How much does the Supplemental Nutrition Assistance Program alleviate food insecurity? Evidence from recent programme leavers. Public Health Nutr. 15, 811-817. doi:10.1017/S1368980011002709

Rasul, G., \& Hussain, A., (2015). Sustainable Food Security in the Mountains of Pakistan: Towards a Policy Framework. Ecol. Food Nutr. 54, 625-643, doi:10.1080/03670244.2015.1052426

Smith, M.D., Kassa, W., Winters, P., (2017a). Assessing food insecurity in Latin America and the Caribbean using FAO's Food Insecurity Experience Scale. Food Policy, 71, 48-61. doi:10.1016/j.foodpol.2017.07.005

Smith, M.D., Rabbitt, M.P., Coleman- Jensen, A., (2017b). Who are the World's Food Insecure? New Evidence from the Food and Agriculture Organization's Food Insecurity Experience Scale. World Dev. 93, 402-412.

Sraboni, E., Malapit, H. J., Quisumbing, A. R., \& Ahmed, A. U. (2014). Women's empowerment in agriculture: What role for food security in Bangladesh?. World Development, 61, 11-52.

Svedberg, P. (2002). Undernutrition overestimated. Economic Development and Cultural Change, 51(1), 5-36. 
World Food Program (2012). Pakistan, Satellite Based Flood Monitoring, 11 September 2012, http://www.wfp.org/category/country/pakistan

Uzma I., \& Muhammad S. B., (2004). Determinants of household food security: An empirical analysis for Pakistan. Int. J. Soc. Econ. 31, 753-766.

doi: $10.1108 / 03068290410546011$

Webb, P., Coates, J., Frongillo, E.A., Rogers, B.L., Swindale, A., Bilinsky, P., (2006). Measuring Household Food Insecurity: Why It's So Important and Yet So Difficult to Do. J. Nutr. 136, 1404S-1408S.

Zeller, M., Schrieder, G., von Braun, J., Heidhues, F., (1997). Rural finance for food security of the poor: Implications for research and policy. Food Policy Review No. 4. International Food Policy Research Institute (IFPRI), Washington, DC.

Zeller, M., \& Sharma, M. (2000). Many borrow, more save, and all insure: implications for food and micro-finance policy. Food policy, 25(2), 143-167. 


\section{Appendix}

Figure 4. 3 Relationship between income (poverty) and food insecurity

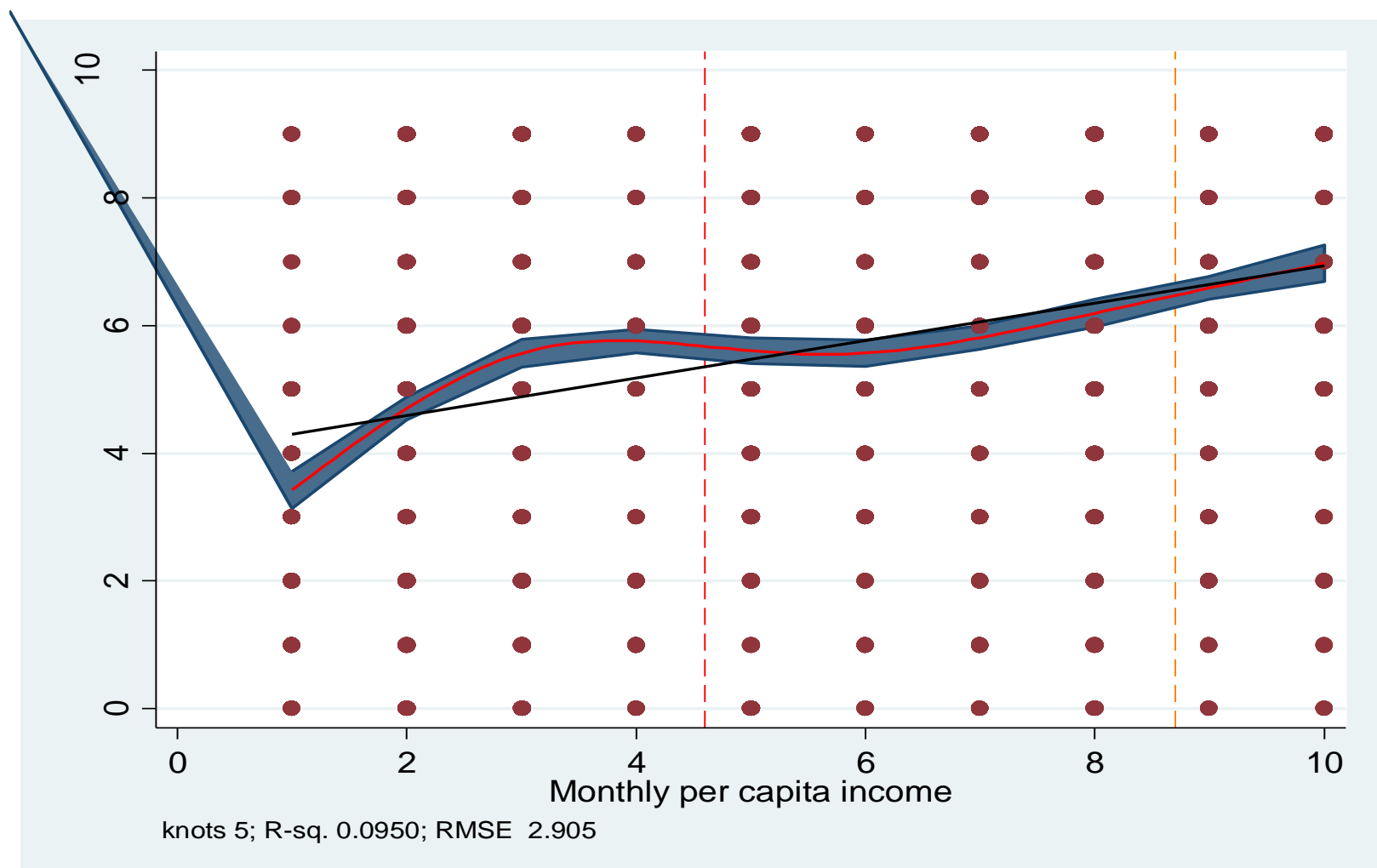

Figure 4. 4 Relationship between food security and poverty

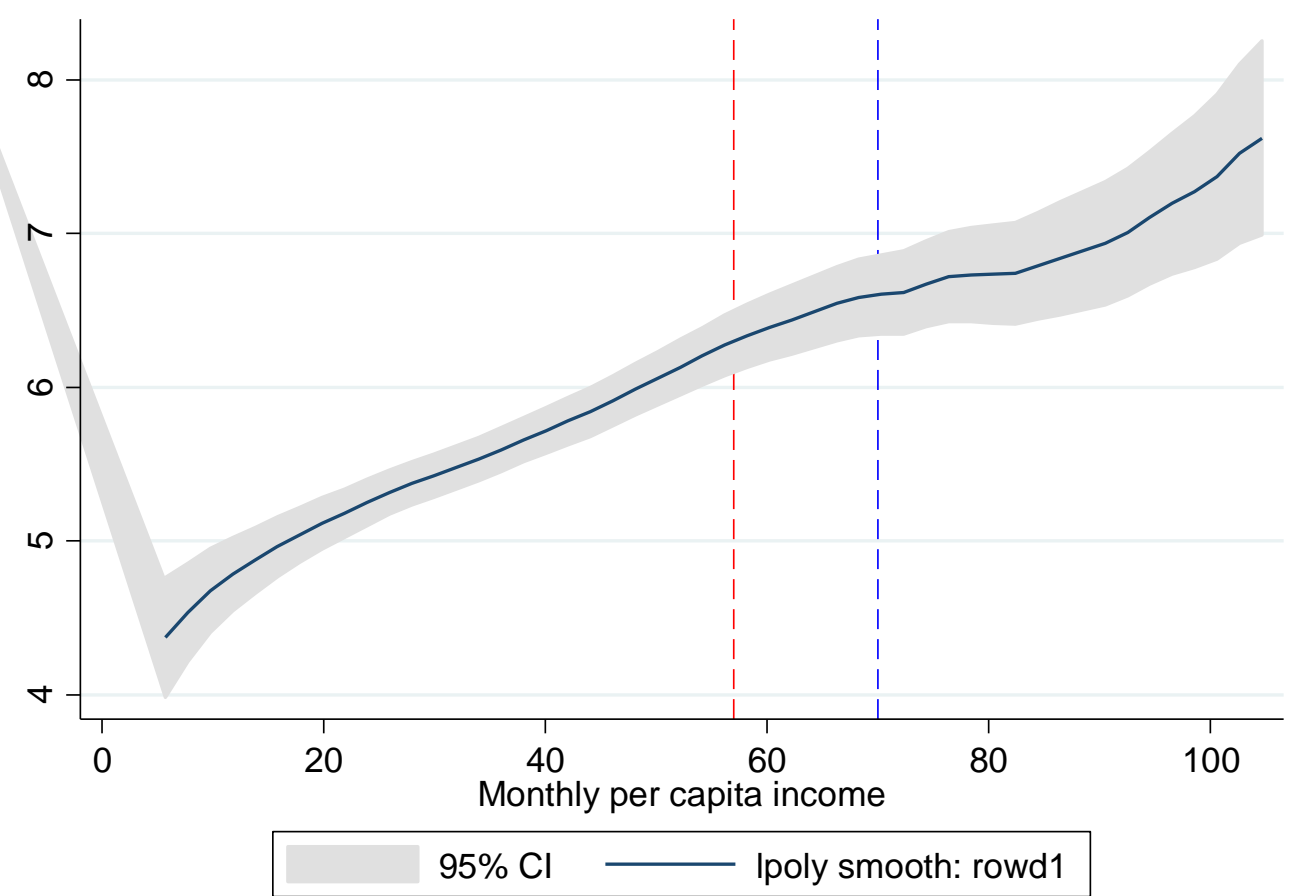

Note: gray area is $95 \%$ confidence interval. 


\section{Chapter 5 Why under five children are stunted in Punjab, Pakistan? Multilevel analysis of Multiple Indicator Cluster Survey (MICS-2014)}

\subsection{Introduction}

Globally in year 2016, about 155 million children ( 23 percent of worldwide children) of less than 5 years are stunted (UNICEF/WHO/World Bank 2017; Smith and Haddad 2015). Almost 50 percent death of children less than five years is due to under-nutrition. A stunted child is both physically short of his/her age and thus fails to grow physically as well as cognitively. Thus, this condition of undernourishment of a child undermines her potential of life from its very manifestation and affects over the life cycle (UNICEF 2014). Undernutrition leads to child morbidity and mortality, poor physical and cognitive development, poor school performance, reduced capacity to work in later life thus loss of productivity and wages (Hodinnot et.al 2008; Black et.al 2013; Aguayo, Badgaiyan and Paintal 2015). Thus, under-nutrition is one of the most pressing challenges of contemporary era due to its longlasting and detrimental consequences (Deaton and Dreze 2009).

Moreover, inadequate nutrition of mother during pregnancy and in the first two years of a child's life (known as first 1000 days of life) is an important window of opportunity to realize a child's full potential of life. If this window of opportunity is missed could cause irreversible and retarded growth, impaired learning and reduced work performance (UNICEF 2014). Stunting a key anthropometric indicator of child health, captures well the different dimensions of child health status, socio-psychological and physical development, cognitive abilities and the environment in which they live (UNICEF 2013; WHO 1995; GranthamMcGregor et al. 2007; Cumming and Cairncross 2016; Schwarz et al. 2008). Stunting is a form of chronic under-nutrition and occurs when a child is short in height of their age relative to WHO child growth standards (WHO 2006). The largest number of stunted children anywhere in the world are present in South Asia i.e., about 87 million which is 56 percent of the total stunted children globally (UNICEF/WHO/World Bank 2017). After India, Pakistan has the highest number of stunted children in South Asia (PDHS 2012-13; Bhutta, Gazdar and Haddad 2013; IFPRI 2016). According to the National Nutrition Survey 2011, of all children under 5 years nearly half are stunted in Pakistan. Moreover, malnutrition is widespread in Pakistan among all age groups and the progress in not promising in the last decades (Das, Achakzai and Bhutta 2016; Raju and D’Souza 2017). For example, in Punjab, 
the stunting prevalence in the year 2011 was 36 percent and in 2014 it is reduced to 33.5 percent (MICS 2016) and this prevalence rate of stunting is alarming for the largest and most developed province of the country.

Punjab contributes more than 52 percent to the national income as well as more than 56 percent of the population of the country resides in this province. It is therefore imperative to analyze the factors, i.e., immediate (Child level characteristics), underlying (mother, father, household and community level characteristics) and basic (i.e., areas of residence, region of residence and regional food security status) associated with stunting in Punjab, Pakistan.

Numerous empirical research studies are available on the determinants of stunting (either moderate stunting or severe stunting). For example, Adekanmbi, Kayode, and Uthman, (2013) examined the main determinants of stunting such as age, gender, multiple birth, low birth-weight, maternal education, household wealth, maternal body mass index and short birth interval. Dewey and Begum, (2011) andHaile, Azage, Mola, and Rainey, (2016) revealed that both individual and community level factors are important determinants of childhood stunting. The result also confirms that 37 percent of stunting is due to community level factors in their study. Apart from child specific characteristics and parental characteristics, the importance of water, sanitation and hygiene (WASH) has been recognized with regard to health of infants and young children, particularly when the process of stunting is concentrated during the first two years of life (Cumming and Cairncross 2016).

Recent studies show that the poor diet of children in the first year of life, poor nutritional status of mother during and after pregnancy, poor sanitation practices, food insecurity and poverty, and social inequalities are significant drivers of childhood stunting (Aguayo and Menon 2016; Joe, Rajaram, and Subramanian 2016; Sharaf, Mansouri and Rashad 2018). In addition, child nutritional status are commonly influenced by factors such as adequate health services and/or lack thereof, nutritional and social services facilities at community/village level and access to these facilities(Menon 2012; Kavosi et. al., 2014; Ahmed, et.al., 2016; Vollmer et al. 2014). Smith and Haddad (2015) using data from 1970 to 2012 for 16 countries found that safe water access, women education, gender equality, and food availability are the main drivers in reducing the stunting. Moreover, when female children suffer from under nutrition, their own children are more likely to be stunted in their first 1000 days (UNSCN 2010).

Although, literature on Pakistan is rather scant (Raju and D'Souza 2017). There are attempts to investigate the determinants of under-nutrition not only at national level but also at micro- 
geographic level (for example; city or administrative division or district level) (see inter alia: Khan et.al. 2016; Khuwaja, Selwyn and Shah 2005; Nuruddin and Haddin 2015; Shah, et.al. 2003; Mushtaq, et.al. 2011; Khalid and Martin 2017). Khuwaja, Selwyn, and Shah (2005) found that stunting is common in lower region of Sind, Pakistan. The study also pinpoints mother illiteracy, low income, and overcrowding as important risk factors of stunting. Similarly, Nuruddin and Hadden (2015) asserts that better literacy among rural mother could reduce stunting, as being female are more likely to be stunted and underweight compared to male. Contrary to this assertion, for Punjab, a study using MICS 2011 data (Khalid and Martin, 2017) explored that female headed household (a measure of female empowerment) had 26 percent lower odds of childhood stunting.

All these research studies focused on employing either ordinary least square (OLS) or binary logistic regression analyses. As standard OLS may over or under-estimate the coefficient of correlates at different points across the distribution of stunting prevalence, thus, bias the estimates. Again, these studies remained unable to quantify the hierarchy of the household level data. These hierarchies have important information to explore for better and targeted policies formulation. Therefore, this study analyzes the Multiple Indictors Cluster Survey of Punjab (MICS-2014) using the multilevel logistic hierarchical models to explore variation at various levels of hierarchy. This analysis will set up the stage for policy level debate and provide the data driven information for public policy design. It is because after the $18^{\text {th }}$ constitutional amendment, provincial autonomy is restored in Pakistan and now it is essential for provinces to formulate the public and social sector policies. This study is first to analyze the determinants of stunting in Punjab Pakistan using Multiple Indicator Cluster survey (MICS-2014) which includes more than 31,000 children of less than five years. In addition, this study uses multilevel modeling approach to unravel the variation at household, community and at district level that is not explored in case of Pakistan at micro-geographic level.

The rest of the paper is organized as follows. Sections 2 discuss data design, variables and describe them. Section 3 presents the empirical method followed by empirical results in section 4 . Section 5 deals with discussion and finally section 6 concludes and provides some suggestions for policy. 


\subsection{Data, hypothesis and variables}

\subsubsection{Data and hypothesis}

The Multiple Indicator Cluster Survey (MICS) is an international household survey program developed by United Nations Children's Fund (UNICEF). MICS is designed to collect statistically sound, internationally comparable estimates of more than one hundred and twenty five key indicators that are used to assess the situation of children and women, in Punjab Pakistan, in the areas of health including anthropometric (nutrition), education, child protection, and HIV/AIDS. MICS Punjab, 2014 was conducted as part of the fifth global round of MICS and was planned, designed and implemented by Punjab Bureau of Statistics (PBS) with a technical support from UNICEF. Fieldwork for MICS data collection across Punjab started in June and completed in September 2014. The universe for MICS consists of all the households and their members in all urban and rural areas of Punjab, which is divided administratively into 9 administrative divisions and 36 districts. A two-stage, stratified cluster sampling approach was used for the selection of the survey sample. In the urban areas, the first-stage selection unit is the Enumeration Block (EB). The stratification of the EB was done by using quality of housing and living standards of the households that make up the block. In the rural areas, the first-stage selection unit is the village. From each of first-stage sample unit, a sample of twenty households selected both in rural and urban areas. Households were considered as secondary sampling units (SSUs) for urban and rural domains. The first-stage units are selected with probability proportional to size. The secondstage units are selected with equal probability. The entire sample of households (SSUs) was drawn from 2050 Primary Sampling Units (PSUs), out of which 774 were urban and 1276 were rural adopting systematic sampling technique with a random start. The final recommended allocation is 2,050 clusters with 20 households in each, giving a total sample of 41,000 households and response rate is almost 98 percent across Punjab province. Detail on MICS Punjab 2014 is provided elsewhere (MICS Punjab Report 2016).

First, the general hypothesis is what are the determinants of stunting in Pakistan? Second we want to test whether there exist stunting variation at households, communities and districts level. We would check the variation of stunting at different levels of model hierarchy. For comparing the linear model with multilevel models we use the LR test. If the LR test rejects the linear model, we will use the multilevel model instead of linear model. 


\subsubsection{Dependent Variable}

Stunting (i.e., moderate and severe) is used as a binary variable in this analysis with not stunted being coded as zero while being stunted coded as one, similar is the case with severe stunted. Stunted is measured as moderate if the height for age $\mathrm{z}$ score of a child less than five years is less than minus 2 standard deviation from WHO reference growth standards and it is severe if $\mathrm{z}$ score is less than minus 3 standard deviation (WHO, 2006).

\subsubsection{Independent Variables}

Independent variables include; individual and household level, community level and district level characteristics. Individual and household level characteristics include; age of child in months and is categorized into (0-5 months, 6-11 months, 12-23 months, 24-35 months, 3647 months and 48-59 months). We divided first year of child into two categories because for the first six months a child is exclusively breast-fed or having milk only as his (her) diet. Moreover, between 6 and 12 months he/she is starting solid food as well. Birth order of child, this variable is a rank number of children born to women of age 15-49 years and categorized into; first born, second born and third or after born having age less than five years. Gender of child is either boy or girl. Size of child at birth is divided into three categories i.e., large (combining very large and larger than average birth size category), average and small (combining smaller than average and very small category). Diarrhea, whether a child had diarrhea in the last two weeks (15 days) is a binary variable (Yes=1; zero otherwise). Breastfeeding is a binary variable if a child is ever breast feed $(Y e s=1)$ and $(N o=0)$. Mother and father's education is categorized as; no education (less than 1 year), primary (1-5 years completed), middle (6-8 years of complete education), secondary (9-10 years of complete education) and higher (11+ years of complete education including professional or university degrees). Mother's age is a categorical variable; less than 18 years, 18-24 years, 25-35 years and 35+ years. Postnatal care is proxied by whether a lady health worker visited the household in the past three months and is a binary variable. This variable captures the knowledge and information exchange that is positively associated with child health outcomes. Antenatal care visits (ANC visits) are number of times a woman received antenatal care during pregnancy and is coded as; up to 4 times as recommended by WHO and 4+ times. Place of delivery where a woman gives birth to her child is coded as home delivery if birth occurred at her own home or at another home and institutional delivery if the delivery occurred at either public or private hospital or maternity care or basic/primary health care center. Household size includes number of household members in a household and is 
categorized into; 3-4 household members, 5-6 household members which is an average size of a family in Punjab, 7-8 household members and more than 8 household members to capture the effect of a very large family on child health outcomes. Community level variables include; ethnicity, place of residence, sanitation facilities, water facilities, and water treatment. Ethnicity is asking about the mother tongue of the head of household and is categorized into; Urdu, Punjabi, Saraiki and Others. Place of residence is a binary variable and coded as urban $=1$ and rural=0. Similarly, the sanitation facility is about the toilet facility a household possesses. It has been divided into two categories according to WHO definition. That is improved sanitation facility of improved sanitation facility which include sewer connections, septic system connection, pour flush latrines, ventilated improved pit latrines and pit latrines with a slab or covered pit, unimproved sanitation facility, which include spit latrines without slabs or platforms or open pit hanging latrines bucket latrines, open defecation in fields, forests and/or bushes. Water treatment is asking a household what household do to make water safer for drinking and is a binary variable coded as treated $=1$ and untreated $=0$. Regional characteristics include districts wise food insecurity index and administrative divisions of province of Punjab. Food insecurity index is taken from SDPI report and this index is at district level. All the three composite indicators (availability of food, access to food, and food absorption) were aggregated to determine the food insecurity level of the districts. The food insecurity indicator was not the simple sum of all composite indicators, but rather principal component analysis (PCA) was used. The PCA is based on the impact of the respective indicators determining the weight (SDPI/SDC/WFP, 2009). The food insecurity index is divided into three categories. (1) Food Insecure (0.53-0.71), (2) Vulnerable (0.72-0.80) and (3) Food Secure (0.81-0.93). Based on these categories we have divided administrative divisions of Punjab as insecure, vulnerable and food secure. Furthermore, Punjab province is divided into nine administrative divisions; Rawalpindi, Bahawalpur, D. G. Khan, Faisalabad, Gujranwala, Lahore, Multan, Sahiwal and Sargodha.

\subsection{Empirical Method}

Many kinds of data including observational data have a hierarchical or clustered structure. For example, children with same parents tend to be more alike in their physical attributes, social attitudes, and mental characteristics than children chosen randomly. Multilevel models recognize the existence of data hierarchies by varying the residual components at each level in the hierarchy. From methodological perspective the justification of using multilevel 
models are due to the fact that traditional multiple regression models treat the units of analysis as independent observations. If we do not take into account the hierarchical structure of the data, the standard errors will be underestimated and their statistical significance will be overstated which leads to the likelihood of type 1 error especially when the underlying variables are differ across the districts or at household (individual) level (Kreft and de Leeuw 1998; Snijders and Bosker 1999). Particularly standard errors of higher-level variables will be affected by ignoring clustering in relative terms. Correct standard errors will be estimated only if variation among groups is allowed and multilevel model provides an efficient way to solve the problem. Multilevel modeling makes it possible for the researchers to investigate the nature of between groups' variability and the effect of group level characteristics on individual characteristics. Alternatively, to account for group level variability in many scenarios the traditional models use dummy variables such as fixed effect model. However, in such models the effects of group level variables are often confounded with the effects of group dummies such as it is often becomes difficult to distinguish the observed and unobserved group characteristics. However, in a multilevel model the effect of both types of variables can be estimated. In a multilevel model, the groups in the sample are treated as a random sample, where it is not possible in the fixed effect model. For example, in many situations a key research question concerns with extent of grouping in individual outcomes. For instance, if we use ordinary regression analysis in finding factors associated with stunting, we assume that for all children the outcomes (in this case, moderate and severe stunting) are independent. Nevertheless, in our analysis more than one child per family are included so that outcomes for siblings may be correlated, especially if nutritional status is dependent on characteristics common to a family such as the quality of parental care, the sanitary conditions within the household etc. Because of these household effects, we would expect stunting for children in the same household or community to be more alike than stunting for children from different households or communities. Furthermore, the multiple indicator cluster survey employ cluster sampling taking census enumeration blocks as primary sampling units so that the data possess hierarchical structure. If conditions within such primary sampling units (hereafter called 'communities') are similar, clustering of nutritional status may occur. Similarly, aggregation bias might emerge, because some divisions are large/developed and some are less developed (SDPI/SDC/WFP 2009; Cheema et.al. 2008). There is likelihood of correlation of independent variables with the dependent variable in different levels. Hence, with the inclusion of cluster effect and regional effect, the 
aggregation bias would be solved. Ordinary regression cannot accommodate such hierarchies in the data. Therefore, multilevel hierarchical data analysis methods are appropriate for our analysis.

We are using three-level random intercept multilevel hierarchical model utilizing MICS 2014 data consists of 25067 children under five, for 9 administrative divisions and 36 districts of Punjab province of Pakistan. In this method, the intercept is allowed to vary randomly across groups. This simply means that the intercept is allowed to take on different values from a distribution. Consequently, a simple three level model without the explanatory variables, which is called unconditional, null or variance component model, is written as:

Stunting ${ }_{i j k}=b_{0}+v_{k}+u_{j k}+e_{i j k}$

$e_{i j k_{\sim}} \mathrm{N}\left(0, \sigma_{\epsilon}^{2}\right) ; u_{j k_{\sim}} \mathrm{N}\left(0, \sigma_{u}^{2}\right) ; v_{k_{\sim}} \mathrm{N}\left(0, \sigma_{v}^{2}\right)$

Where Stunting Sijk $_{\text {is }}$ is the observed value of being $\left(\right.$ Stunting $\left._{i j k}=1\right)$ both moderately and severely stunted and being non-stunted $\left(\right.$ Stunting $_{i j k}=0$ ) child under-five in household $i$, in community $j$ and in district $k$. The model includes intercept $\left(b_{0}\right)$, that measures the overall mean of stunting across all districts, communities and households in Punjab. $v_{k}$ is the effect of district $k, u_{j k}$ is the effect of community $j$ in the district $k$, and $e_{i j k}$ is the observational level error term here household. The district, community, and household variance components, $\sigma_{v}^{2}, \sigma_{u}^{2}, \sigma_{\epsilon}^{2}$ respectively measures variation across three different levels of hierarchy.

First, it is imperative to establish that the model fits the data significantly better than two level as well as single level model which include no cluster effects. The Likelihood ratio $(L R)$ test statistic for testing the null joint hypothesis is calculated as: $\mathrm{LR}=\left(-2 \log L_{0}\right)-\left(-2 \log L_{1}\right)$. Where $L_{0}$ and $L_{1}$ are the likelihood values for the single-level model and the three-level model, respectively. The LR test statistic is then compared to a chi2 distribution with degrees of freedom equal to the number of extra parameters in the more complex model; hence two. The resulted $p$-value is then used to assess whether the three level models fits significantly better than the single level model.

Several approaches are available to interpret variance components in multilevel models; we are considering here the; variance partition coefficients (VPCs) and intra class correlation coefficients (ICCs). The VPC statistics report the proportion of the response variance that lies at each level of the model hierarchy. Thus, the total variance is simply the sum of the three separate variance components. The district, community and household level VPCs are 
calculated as the ratio of the respective level variance to the total variance and given as follows; $V P C_{d i s t t}=\frac{\sigma_{v}^{2}}{\sigma_{v}^{2}+\sigma_{u}^{2}+\sigma_{e}^{2}}, V P C_{\text {comm }}=\frac{\sigma_{u}^{2}}{\sigma_{v}^{2}+\sigma_{u}^{2}+\sigma_{e}^{2}}, V P C_{h h}=\frac{\sigma_{e}^{2}}{\sigma_{v}^{2}+\sigma_{u}^{2}+\sigma_{e}^{2}}$. The ICC measures the expected degree of similarity between responses within specific level. The strength of the correlation depends on the extent to which different households belong to the same higher level. For example, households who share the same community or same districts are more alike and hence more correlated than households who share different geographic location. The district level ICC is the same as the VPC. While community level ICC is different from the corresponding VPC, which is given as; ICC distt $=\frac{\sigma_{v}^{2}}{\sigma_{v}^{2}+\sigma_{u}^{2}+\sigma_{e}^{2}} ; I C C_{c o m m}=\frac{\sigma_{v}^{2}+\sigma_{u}^{2}}{\sigma_{v}^{2}+\sigma_{u}^{2}+\sigma_{e}^{2}}$. Finally, the three-level model with the explanatory variables is given as under.

Stunting $_{i j k}=b_{0}+b_{i} X_{i j k}+v_{k}+u_{j k}+e_{i j k}$

where $X_{i j k}$ is a vector of explanatory variables at district, community (village), household and individual level? All other symbols are similar as in equation (1).

\subsection{Empirical Results}

\subsubsection{Bivariate Analysis Results}

Table 5.1 presents the prevalence of moderate and severe childhood stunting in percentages (\%) at various levels of covariates, the level of significance of each variable with that of response variable set at $\mathrm{P}$-value $<0.05$. A little more than a quarter $(27.4 \%)$ children are moderately stunted and one-tenth (10.4\%) are severely stunted in Punjab, Pakistan. Furthermore, 63 percent of children are moderately stunted between the age group of 36 months to 59 months whereas about 25 percent are severely stunted in the same age group. The figure for 0-11 months is 30 percent moderately stunted while 11 percent severely stunted children. Thus, child age is an important and significant predictor of the health outcomes. Childbirth order is an important risk factor for child stunting outcomes. For example, if a child birth order is 3 or above the child has more likelihood of being stunted $(30 \%)$ and severely stunted (11\%). Whereas a little more than one-fourth (27\%) of first-born are likely to be stunted and one-tenth (10\%) likely to be severely stunted. Of note, $27 \%$ boys and $28 \%$ girls are moderately stunted whereas $10 \%$ boys and 11 girls are severely stunted. Girls are facing significantly higher burden of moderate and severe stunting. Child size at birth is also an important predictor, for example, children born larger than average size are $(21 \%)$ moderately stunted and $(8 \%)$ severely stunted but those born with smaller than average birth size are $36 \%$ moderately and $15 \%$ severely stunted. Almost $24 \%$ children who 
breastfeed are moderately and about $9 \%$ severely stunted compared to $25 \%$ those who are not breast feed are moderately stunted and $12 \%$ severely stunted. Children having diarrhea are more likely to be stunted (31\%) compared to those who are not having diarrhea (27\%).

Lower the mother's education higher the chances that a child is facing stunting. For example, a woman with low education has higher likelihood of having stunted children (36\% moderate and $15 \%$ severe) compared to highly educated (9\% moderately stunted and $2 \%$ severely stunted). Children whose father is educated (13\% moderate and $4 \%$ severe stunting) are less likely to be stunted compared to those children whose father is not educated (38\% moderate and $17 \%$ severe stunting).

Table 5.1 Prevalence of moderate and severe childhood stunting at various levels of independent variables in Punjab, Pakistan (Punjab MICS-2014)

\begin{tabular}{lllllll}
\hline Variables & \multicolumn{2}{l}{ Stunting } & \multicolumn{2}{l}{ Soderate SD $<-2)$} & \multicolumn{3}{l}{ Stunting (Severe SD $<-3)$} \\
\cline { 2 - 7 } & Total & Yes & No & Total & Yes & No \\
& & $\mathrm{N}(\%)$ & $\mathrm{N}(\%)$ & & $\mathrm{N}(\%)$ & $\mathrm{N}(\%)$ \\
\hline Total & 25066 & 6865 & 18201 & 25066 & 2602 & 22464 \\
& & $(27.4)$ & $(72.6)$ & & $(10.4)$ & $(89.6)$
\end{tabular}

Individual and Household Level characteristics

$\begin{array}{lllllll}\text { Age Group } & <0.001 & & & <0.001 & \\ 0-5 & 2,177 & 247(11) & 1,930(89) & 2,177 & 99(5) & 2,078(95) \\ 6-11 & 2,767 & 531(19) & 2,236(81) & 2,767 & 157(6) & 2,609(94) \\ 12-23 & 4,827 & 1,484(31) & 3,343(69) & 4,827 & 569(12) & 4,258(88) \\ 24-35 & 4,838 & 1,266(26) & 3,572(74) & 4,838 & 478(10) & 4,360(90) \\ 36-47 & 5,373 & 1,785(33) & 3,588(76) & 5,373 & 657(12) & 4,716(88) \\ 48-59 & 5,082 & 1,549(30) & 3,533(70) & 5,082 & 641(13) & 4,441(87) \\ \text { Birth Order } & 0.04 & & & 0.023 & & \\ \text { 1st } & 16,391 & 4,415(27) & 11,976(73) & 16435 & 1641(10) & 14794(90) \\ \text { 2nd } & 7,323 & 2,046(28) & 5,277(68) & 7323 & 816(11) & 6507(89) \\ \text { 3+ } & 1,351 & 403(30) & 948(70) & 1351 & 144(11) & 1207(89) \\ \text { Gender of Child } & 0.024 & & & >0.001 & & \\ \text { Boy } & 12,712 & 3,384(27) & 9,328(73) & 12712 & 1231(10) & 11481(90) \\ \text { Girl } & 12,354 & 3,481(28) & 8,873(68) & 12354 & 1371(11) & 10983(89) \\ \text { Size at Birth } & 0.001 & & & 0.001 & & \\ \text { Large } & 1,052 & 218(21) & 834(79) & 1052 & 80(8) & 972(92) \\ \text { Average } & 8,862 & 2,281(26) & 6,581(74) & 8862 & 846(10) & 8016(90) \\ \text { Small } & 2,633 & 938(36) & 1,695(64) & 2633 & 406(15) & 2227(85) \\ \text { Diarrhea } & <0.001 & & & <0.001 & & \\ \text { Yes } & 4391 & 1344(31) & 3047(69) & 4391 & 556(13) & 3835(87) \\ \text { No } & 20676 & 5522(27) & 15154(73) & 20675 & 2046(10) & 18629(90) \\ \text { BreastFeeding } & >0.001 & & & >0.001 & & \\ \text { Yes } & 13950 & 3365(24) & 10585(76) & 13949 & 1226(9) & 12723(91) \\ \text { No } & 703 & 179(25) & 524(75) & 703 & 81(12) & 622(88) \\ \text { Mother Education } & <0.001 & & & <0.001 & & \\ \text { Noeducation } & 12,270 & 4,428(36) & 7,842(64) & 12,270 & 1,861(15) & 10,409(85) \\ \text { Primary } & 4,517 & 1,149(25) & 3,368(75) & 4,517 & 367(8) & 4,150(92) \\ \text { Middle } & 2,481 & 508(20) & 1,973(80) & 2,481 & 156(6) & 2,325(94) \\ \text { Secondary } & 3,101 & 529(17) & 2,572(83) & 3,101 & 156(5) & 2,945(95)\end{array}$




\begin{tabular}{|c|c|c|c|c|c|c|}
\hline Higher & 2,696 & 249(9) & $2,447(91)$ & 2,696 & $63(2)$ & $2,633(98)$ \\
\hline Mother Age & 0.042 & & & 0.305 & & \\
\hline$<18$ & 1,696 & 499(29) & $1,197(71)$ & 1,696 & $185(11)$ & $1,511(89)$ \\
\hline $18-24$ & 5,148 & $1,323(26)$ & $3,825(74)$ & 5,148 & $495(10)$ & $4,653(90)$ \\
\hline $25-35$ & 13,893 & $3,810(27)$ & $10,083(73)$ & 13,893 & $1,428(10)$ & $12,465(90)$ \\
\hline $36+$ & 4,327 & $1,232(28)$ & $3,095(72)$ & 4,327 & $492(11)$ & $3,835(89)$ \\
\hline Antenatal Care & $>0.001$ & & & $>0.001$ & & \\
\hline $1-4$ visits & 6169 & $1725(28)$ & $4444(72)$ & 6169 & $625(10)$ & $5544(90)$ \\
\hline $5+$ visits & 3914 & $718(18)$ & $3196(82)$ & 3914 & $253(6)$ & $3661(94)$ \\
\hline Postnatal Care & 0.723 & & & 0.431 & & \\
\hline Yes & 4764 & $1315(28)$ & $3449(72)$ & 4764 & $517(11)$ & 4247(89) \\
\hline No & 7703 & $2100(27)$ & $5603(73)$ & 7703 & $799(10)$ & $904(90)$ \\
\hline Child Delivery & $>0.001$ & & & $>0.001$ & & \\
\hline Home & 5452 & 1884(35) & $3568(65)$ & 5452 & $773(14)$ & $4679(86)$ \\
\hline Hospitals & 7150 & $1567(22)$ & $5583(78)$ & 7150 & $562(8)$ & $6588(92)$ \\
\hline Father Education & $<0.001$ & & & $<0.001$ & & \\
\hline Noeducation & 7,335 & $2,814(38)$ & $4,521(62)$ & 7,335 & $1,217(17)$ & $6,118(83)$ \\
\hline Primary & 4,536 & $1,419(31)$ & $3,117(69)$ & 4,536 & $524(12)$ & $4,012(88)$ \\
\hline Middle & 4,138 & $1,024(25)$ & $3,114(75)$ & 4,138 & $326(8)$ & $3,812(92)$ \\
\hline Secondary & 5,507 & $1,144(21)$ & $4,363(79)$ & 5,507 & $391(7)$ & $5,116(93)$ \\
\hline Higher & 3,548 & $463(13)$ & $3,085(87)$ & 3,548 & $144(4)$ & $3,405(96)$ \\
\hline WealthIndex & $<0.001$ & & & $<0.001$ & & \\
\hline Poor & 11,167 & $4,155(37)$ & $7,012(63)$ & 11167 & 1770(16) & $9397(84)$ \\
\hline Middle & 4,915 & $1,218(25)$ & $3,697(75)$ & 4915 & $395(8)$ & $4520(92)$ \\
\hline Rich & 8,983 & $1,491(17)$ & $7,492(83)$ & 8983 & $436(5)$ & $8547(95)$ \\
\hline Household Size & $>0.001$ & & & $>0.002$ & & \\
\hline 3-4 members & 2,873 & $705(25)$ & $2,168(75)$ & 2873 & $250(9)$ & $2623(91)$ \\
\hline 5-6 members & 7,179 & $1,983(28)$ & $5,196(68)$ & 7179 & $774(11)$ & $6405(89)$ \\
\hline 7-8 members & 6,177 & $1,838(30)$ & $4,339(70)$ & 6177 & $706(11)$ & 5471(89) \\
\hline $8+$ members & 8,836 & $2,339(26)$ & $6,497(74)$ & 8836 & $871(10)$ & $7965(90)$ \\
\hline \multicolumn{7}{|c|}{ Community Level Characteristics } \\
\hline Ethnicity & $>0.001$ & & & $>0.001$ & & \\
\hline Urdu & 1,267 & 243(19) & $1,024(81)$ & 1267 & $76(6)$ & 1191(94) \\
\hline Punjabi & 16,141 & $3,967(25)$ & $12,174(75)$ & 16141 & $1332(8)$ & $14808(92)$ \\
\hline Saraikai & 6,040 & $2,139(35)$ & $3,901(65)$ & 6040 & $973(16)$ & $5067(84)$ \\
\hline Others & 1,617 & $515(32)$ & $1,102(68)$ & 1617 & 221(13) & $1396(87)$ \\
\hline Region & $>0.001$ & & & $>0.001$ & & \\
\hline Urban & 7842 & $1620(21)$ & $6222(79)$ & 7842 & $538(7)$ & $7304(93)$ \\
\hline Rural & 17224 & $5245(30)$ & $11979(70)$ & 17224 & 2063(12) & $15161(88)$ \\
\hline Sanitation & $>0.001$ & & & $>0.001$ & & \\
\hline Improved & 17903 & $4185(23)$ & $13718(77)$ & 17903 & $1429(8)$ & $16474(92)$ \\
\hline Unimproved & 7163 & $2679(37)$ & $4484(63)$ & 7163 & $1173(16)$ & $5990(84)$ \\
\hline WaterFacilities & $>0.001$ & & & $>0.001$ & & \\
\hline Improved & 23613 & $6584(28)$ & 17029(72) & 23613 & $2507(11)$ & 21106(89) \\
\hline Unimproved & 1453 & 281(19) & $1172(81)$ & 1453 & $94(7)$ & $1359(93)$ \\
\hline Water Treatment & $>0.001$ & & & $>0.001$ & & \\
\hline Treated & 1524 & $228(15)$ & $1296(85)$ & 1425 & $82(5)$ & 1443(95) \\
\hline Untreated & 23542 & $6638(28)$ & $16904(72)$ & 23524 & $2521(11)$ & $21023(89)$ \\
\hline \multicolumn{7}{|c|}{ Regional LevelCharacteristics } \\
\hline $\begin{array}{l}\text { Food } \\
\text { InsecurityIndex } \\
\text { (FII) }\end{array}$ & $>0.001$ & & & $>0.001$ & & \\
\hline Insecure & 2,662 & $1,035(39)$ & $1,626(61)$ & 2662 & $482(18)$ & $2179(82)$ \\
\hline Vulnerable & 8,875 & $2,598(29)$ & $6,277(71)$ & 8875 & $1016(11)$ & $7859(89)$ \\
\hline
\end{tabular}




\begin{tabular}{lllllll}
$\begin{array}{l}\text { Secure } \\
\text { Division }\end{array}$ & $\begin{array}{l}13,529 \\
<0.001\end{array}$ & $3,232(24)$ & $10,297(76)$ & $\begin{array}{l}13529 \\
<0.001\end{array}$ & $1104(8)$ & $12425(92)$ \\
\hline Rawalpindi & 1,909 & $312(16)$ & $1,597(84)$ & 1,909 & $86(5)$ & $1,823(95)$ \\
Bahawalpur & 2,930 & $1,016(35)$ & $1,914(65)$ & 2,930 & $432(15)$ & $2,498(85)$ \\
D.G Khan & 2,822 & $1,112(39)$ & $1,710(61)$ & 2,822 & $528(19)$ & $2,294(81)$ \\
Faisalabad & 3,115 & $758(24)$ & $2,357(76)$ & 3,115 & $272(9)$ & $2,843(91)$ \\
Gujranwala & 3,234 & $727(22)$ & $2,507(78)$ & 3,234 & $235(7)$ & $2,999(93)$ \\
Lahore & 4,416 & $1,093(25)$ & $3,323(75)$ & 4,416 & $378(9)$ & $4,038(91)$ \\
Multan & 2,853 & $823(29)$ & $2,030(71)$ & 2,853 & $326(11)$ & $2,527(89)$ \\
Sahiwal & 1,880 & $522(28)$ & $1,358(71)$ & 1880 & $188(10)$ & $1691(90)$ \\
Sargoda & 1,904 & $500(26)$ & $1,404(74)$ & 1904 & $155(8)$ & $1749(92)$ \\
\hline
\end{tabular}

If a woman marries as a child (marriage age less than 18 years) about $29 \%$ of their children are moderately stunted and $11 \%$ severely stunted. Whereas those marry after 36 years of age $28 \%$ of their children are stunted and $11 \%$ are severely stunted. A significantly high number of children (30\%) living in rural areas are moderately stunted relative to $21 \%$ in urban areas where as about 12 percent severely stunted compared to 7 percent in urban areas. Every fourth Punjabi child is stunted in Punjab province. Being Siraiki (an ethnic group predominantly living in southern Punjab) significantly determines the stunting of a child compared to Urdu speaking (35\% versus 19\%). There are significant differences among the administrative divisions of the Punjab province. For example, Rawalpindi division has significantly lower prevalence of moderate and severe stunting (16\% moderate and $5 \%$ severe stunting) compared D. G. Khan, Bahawalpur and Multan (39\%, 35\% and 29\% moderate stunting and 19\%, 15\% and $11 \%$ severe stunting) respectively. Every fourth child in Lahore, the provincial capital of Punjab, is moderately stunted and every tenth child is severely stunted. Those household having unimproved water and sanitation facilities are highly likely to have more stunted children (sanitation: $37 \%$ versus $23 \%$ and Water: unimproved $19 \%$ versus improved $28 \%$ ) relative to those household having improved water and sanitation facilities. Almost 39 percent (18 percent) of those children living in food insecure districts are moderately (severely) stunted relative to 29 percent (11 percent) in vulnerable (borderline) districts and 24 percent ( 8 percent) in food secure districts.

\subsubsection{Multivariate Analysis Results}

The LR test rejects the null hypothesis of linear model instead of three level multilevel models. Table 5.2 and 5.3 presents the results of the multilevel logistic regression analyses and the results are presented as Odds ratio (OR) with their 95\% Confidence Interval (95\% CI). Furthermore, in our analysis Model 1 is empty, base, unconditional and three level hierarchical model. Whereas, Model 2 includes child and parental characters, model 3 includes household characteristics along with child, parental characters and model 4 include 
child, parental, household and regional characters (e.g., district level food insecurity index and administrative divisions). Our three level of hierarchy are household (i), community (j), and districts $(\mathrm{k})$.

Results of multilevel models 1-4 are presented in table 5.2-5.3. Model 2 in Table 5.2 presents results of only child specific and parent's level characters and their association with moderate stunting. For example, compared to reference category of zero to five months, children of 6 to 11 months are 2 and half times more likely to be stunted (OR=2.58, CI=1.9-3.5) whereas children of age 12-23 months are 7 times more prone to be stunted. Girls are significantly more likely to be stunted than boys $(\mathrm{OR}=1.14,95 \% \mathrm{CI}=1.1-1.2)$. Children whose birth order is second is significantly likely to be stunted $(\mathrm{OR}=1.5795 \% \mathrm{CI}=1.4-1.8)$ whereas children whose birth order is 3 or more is 3 times more likely to be stunted (OR=3.14 95\% CI=2.44.1). Children with no breastfeeding are significantly likely to be moderately stunted $(\mathrm{OR}=1.3595 \% \mathrm{CI}=1-1.7)$ than those children who had breastfeeding. Children with no diarrhea are significantly less likely to be stunted compared to those having an episode of diarrhea. Children whose size at birth perceived smaller are more than 2.6 times likely to be moderately stunted than those who have large size at the time of birth. Mothers' education is a significant covariate of moderate stunting. Compared to no education, reference category, children of highly educated mothers are significantly less likely to be moderately stunted $(\mathrm{OR}=0.2595 \% \mathrm{CI}=0.2-0.3)$. Whereas children of Primary $(\mathrm{OR}=0.6795 \% \mathrm{CI}=0.6-0.8)$ and Middle school completed mothers (OR=0.51 95\% CI=0.4-0.6) are significantly less likely than no educated mothers to be stunted. Children of father who has higher education are less likely to be stunted $(\mathrm{OR}=0.4095 \% \mathrm{CI}=0.3-0.5)$. Living in rural areas is a risk factor of moderate stunting. The results of severe stunting (less than minus 3 SD) are presented in table 5.3. The findings are in line with the moderate stunting with the similar magnitude and significance of coefficients. This confirms the robustness of the results.

Now we will discuss the variability of stunting among different levels. The hierarchical nature of the data set implies that the stunting at the household level may not only be correlated with the individual characteristics, but also be influenced by the community level and/or district level as well. Model 1 is an unconditional multilevel logistic regression model, which decompose the variance into three levels without incorporating any explanatory variables. The model is used as a base line model for comparison with other models to check the explanatory power of independent variables at different levels. The $L R$ test favored the multilevel logistic regression instead of conventional logistic regression, shown by the 
statistically significant $\left(L R \chi^{2}=1005.94, P<0.001\right)$ for moderate stunting and $\left(L R \chi^{2}=\right.$ 628.88, $P<0.001$ ) for severe stunting (see Table 5.2-5.3).

Table 5.4 presents the results of VPC and ICC for both moderate and severe stunting. Moreover, the unconditional models simply decompose the total outcome variance into level specific variance components. In conditional models 2-4 (incorporating the explanatory variables), however, the $V P C$ and $I C C$ are based on the residual rather than observed outcomes. Thus, VPC measure the proportion of outcome variation unexplained by the predictor variables that falls at each level of the model hierarchy. Similarly, ICC measures the similarity in unexplained outcomes.

The total variance (unconditional model 1) by combining the variation at three levels (household, community and district) is estimated to be $2.08(=0.37+0.53+1.18)$ from table 5.2 for moderate stunting. The unconditional random intercept mixed effect model for moderate stunting shows the variance at the district level explain $17 \% \quad(=0.37 / 2.08)$ proportional change in variance $(V P C)$ of total variance, a significant amount of variation across district level. The community level variance shows that $25 \%(=0.53 / 2.08)$ of variation is explained by community level. Moreover, the household level variation implies that the risk of stunting varies across household level significantly by $56 \%(=1.18 / 2.08)$. Similarly, looking at the ICC statistics of moderate stunting (unconditional model 1), we find that the district and community level ICC is 0.17 and 0.43 respectively. Thus, the correlation between two households from the same district, but different community is 0.17 , while the correlation between two households from the same district and same community is higher at 0.43 . This means that households in the same community have higher chance of correlation than the households of adjacent communities. This also shows that variance in the odds of child being stunted is explained $17 \%$ by district and $43 \%$ by community characteristics.

The total variance (unconditional model 1$)$ is estimated to be $2.19(=0.48+0.55+1.16)$ for severe stunting from table 5.3. The variance explain $22 \%(=0.48 / 2.19)$ (variance partition coefficient $V P C$ ) of total variance; a relatively significant amount of variation across district. The community level variance shows that $25 \%(=0.55 / 2.19)$ of all variation is explained by community level factors. Moreover, the household level variation implies that the risk of stunting varies across household level significantly by 53\% (=1.16/2.19). Similarly, the ICC statistics of severe stunting are estimated and interpreted.

We conclude that the VPC and ICC statistics show high degree of clustering in the Punjab stunting data. However, majority of the variation in stunting both moderate and severe lies at 
the household level. The differences could be due to income inequality, access to health care facility, food insecurity of households and etc. Hence, the findings imply that stark variation exist among households demographic and socio-economic characteristics. Therefore, for policy relevance, household level nutrition related policy should be prioritized, followed by community and districts level measures.

\subsection{Discussion}

We have analyzed the determinants of under nutrition (stunting) in Punjab Pakistan using Multiple Indicator Cluster survey (MICS-2014) which include 25,067 children of less than five years after cleaning the data. Moreover, the study utilizes multilevel hierarchical model at household, community and district level to capture the variation at various level of hierarchy. Our results indicate that stunting and severe stunting is a daunting public health challenge of the province of Punjab, Pakistan because almost a little more than one fourth $(27.4 \%)$ of children are moderately stunted and $10 \%$ are severely stunted in 2014 . This number is alarming. The key individual and household level covariates significantly associated with stunting and severe stunting are; age of child, birth order of child, being female, being smaller in size at birth, episode of diarrhea, breast feeding, mother and father education, and wealth status of household. Number of studies done on Africa and south Asia found that risk of stunting and sever stunting increases with increase in age of a child (Chirande et.al. 2015; Ahsan et.al. 2017; Khan et.al. 2016; Aheto, Keegan, Taylor and Diggle 2015; Haile, Azage, Mola and Rainy 2016; Gewa and Yandell 2012). It is due to the fact that stunting can start during pregnancy (in utero) and is confirmed by a study using WHO child malnutrition and growth database as the average $\mathrm{z}$ score of infants drop rapidly until the age of 2 years (De Onis and Branca 2016; Victora et.al. 2010). Moreover, as child grow their needs for food and diverse diet increases as well as their requirements for calorie intake. Given the limited household resources it is certain that with the growing body needs unfulfilled, stunting will result. 
Child birth order is an important risk factor for child health outcomes. The higher the birth order it is highly likely that the odds of a child being stunted increases 3 folds which is in line the studies from India and Africa (Howell, Holla and Waidmann 2016; Horton 1988; Jayachandran and Pande 2017). For India, the study by Jayachadran and Pande (2017) explains that it is due to son preference and other reasons that mother's time allocation for child care is distributed among children in the household and competition for household food and non-food resources (Rahman 2016). Gender of a child is an important factor in stunting outcome for example; Girls are facing relatively higher burden of stunting. Girls have 27\% higher odds of being severely stunted and $14 \%$ moderately stunted relative to boys. This finding is in line with the study from Nepal and Pakistan (Tiwari, Ausman and Agho 2014; Hazarika 2000) and from rural Thatta, Pakistan (Nuruddin and Hadden) but in contrast with findings from Bhutan and Bangladesh (Aguayo, Badgaiyan and Paintal 2015; Choudhury et.al. 2016). This gender bias depicts the patriarchal nature of social setup especially in Punjab, Pakistan. This is confirmed by a study of 61 countries by Bongaarts (2013) which ranked Pakistan second highest desired sex ratio for boys. Furthermore, gender discrimination and patriarchy leave female sex behind and neglect their basic rights like food. The findings of our study showed that Children with diarrhea, rural residence (only in model 2 for moderate stunting), smaller than average size at birth and less breast feeding at the earlier stages are more likely to be stunted. These results are also reported in other studies (see interalia; Rakotomanana, Gates, Hilderbrand and Stoecker 2016; Nkurunziza, Meessen, Geertruyden and Korachais 2017; Rahman 2016; Shinsugiet.al. 2015). Mother and Fathers' higher education status is associated significantly with the less likelihood of child of less than five years being stunted (moderate and severe) in Punjab, Pakistan. This result is in line with other studies from Asia and Africa (Abuya, Ciera and Kimani 2012, Khalid and Martin 2017; Som, Pal and Bharati 2007; Dorsey et.al. 2018; Vollmer et.al. 2016). Although the channels through which education of parents can affect child health outcomes are debated as it hypothesized that higher educated parents are relatively better endowed with (health care) knowledge and resources, relatively rich and better able to provide childcare (Glewwe 1999; Vollmer et al. 2015; Gautam, Adhikari, Khatri and Devkota 2016). 
There are significant differences among the administrative divisions of the Punjab province. For example, Rawalpindi division has significantly lower prevalence of moderate and severe stunting and compared to Rawalpindi, a child living in Lahore is twice likely to be stunted (moderate and severe) which is a surprising result given the relative socio-economic development of Lahore division compared to other administrative divisions of the province. One possible explanation is due to its metropolitan nature. Lahore division is relatively expensive to bear household food and non-food expenditure especially for households with limited resources. Another possible reason can be that due to urbanization (82\% population is urban in Lahore division) and expansion of Lahore it is highly congested (3500 person per square in Lahore district one of the highest in Punjab province and average household size 7.2 persons) and polluted city (poor living and unhygienic conditions) of the province which is detrimental for food absorption and health especially of children of younger ages (Cheema et al. 2008; Khalid and Martin 2017). This result also points towards nutritional inequalities that exist among the administrative divisions of the Punjab province. This area of research need further in depth empirical investigation. Mother's age at marriage, household size, pre and postnatal care, drinking water facility and region of residence are not significant predictors of moderate and severe stunting in any of the models estimated. However, communities with improved sanitation facility have less likelihood of child being moderately or severely stunted. This finding is in line with the previous results reported by other studies (Torlesse, Cronin, Sebazang and Nandz 2016; Cumming and Cairncross 2016; Spears 2013). Fink et al. (2011), analyzed the data from 172 Demographic and Health surveys and showed that likelihood of stunting in household with sanitation facilities were relatively lower.

However, this study has some limitation; as this study is representative of the province of Punjab, it is rather difficult to generalize the findings of study for other provinces of Pakistan. Nevertheless, the findings of the study will be helpful in guiding the factors associated with stunting (moderate and severe) for other provinces and thus setting the provincial priorities. This is a cross sectional data and thus causal inference cannot be concluded from the findings. Furthermore, the MICS data did not provide data about mother's nutritional status and hence we remain unable to include this variable. It is therefore recommended that next round of MICS data must include nutrition of mother as an indicator or mother and child health as well. Nevertheless, in the analyses we controlled for household wealth status, mother education and region of residence which may partly explain mother's nutritional status and child care. 


\subsection{Conclusion and Policy Implications}

The findings of this study confirm that the child specific, household, and district characteristics have strong predicting power in the explanation of stunting (moderate and severe). Furthermore, the results also reveal that stark differences exist among household level, while at the community and district level the variances decreases as we incorporate the explanatory variables. Nonetheless, the findings of the study are useful for setting up policy priorities as well as formulating multi-sectoral nutrition programs for achieving sustainable development goals related to nutrition and hunger. Similarly, this study set up the stage for debate as the year 2018 is election year in Pakistan and thus study is baseline for setting political and public policy priorities for reducing the stunting in children of less than five years in Punjab, Pakistan. The findings of this study have strong policy implication, indicating focus should be on the household while making public policy. Nevertheless, policy makers should not forget the role of community (village) and district level factors in policy priorities. 
Table 5.2 Multivariable Regression results of Multilevel Models Punjab (MICS-2014)

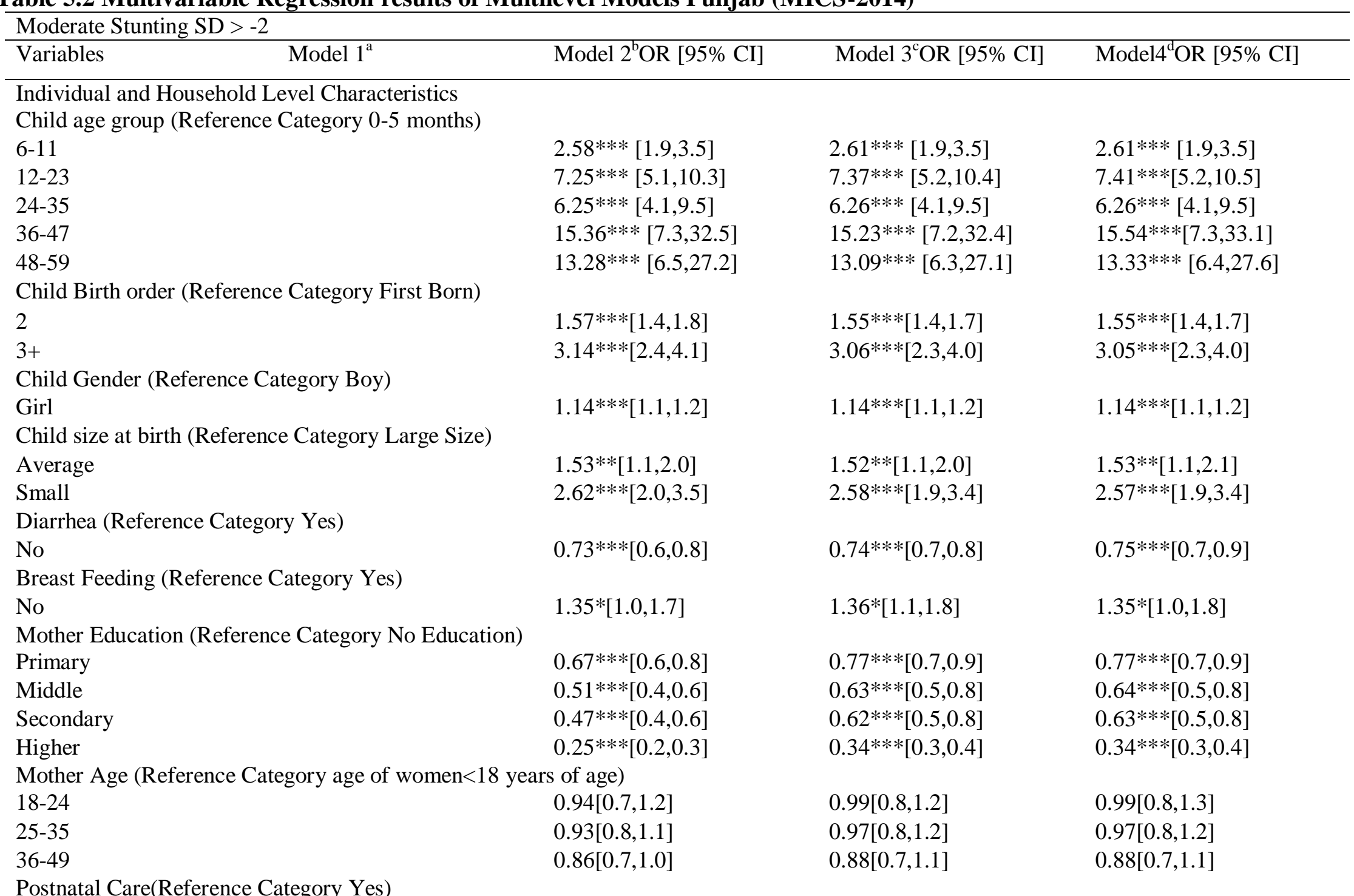




\begin{tabular}{|c|c|c|c|}
\hline \multicolumn{4}{|l|}{ Moderate Stunting SD > -2 } \\
\hline Variables $\quad{\text { Model } 1^{\mathrm{a}}}$ & Model $2{ }^{\mathrm{b}} \mathrm{OR}[95 \% \mathrm{CI}]$ & Model $3^{\mathrm{c}} \mathrm{OR}[95 \% \mathrm{CI}]$ & Model4 ${ }^{\mathrm{d}}$ OR $[95 \% \mathrm{CI}]$ \\
\hline No & $0.97[0.9,1.1]$ & $0.98[0.9,1.1]$ & $0.97[0.9,1.1]$ \\
\hline \multicolumn{4}{|c|}{ Prenatal Care(Reference category 1-4 visits) } \\
\hline More than 4 visit & $0.88[0.8,1.0]$ & $0.94[0.8,1.1]$ & $0.95[0.8,1.1]$ \\
\hline \multicolumn{4}{|l|}{ Delivery Place(Reference category Home) } \\
\hline Hospital & $0.93[0.8,1.1]$ & $0.98[0.8,1.1]$ & $0.98[0.8,1.1]$ \\
\hline \multicolumn{4}{|c|}{ Father Education(Reference category No Education) } \\
\hline Primary & $0.85 *[0.7,1.0]$ & $0.90[0.8,1.0]$ & $0.91[0.8,1.0]$ \\
\hline Middle & $0.65 * * *[0.6,0.7]$ & $0.71 * * *[0.6,0.8]$ & $0.72 * * *[0.6,0.8]$ \\
\hline Secondary & $0.56 * * *[0.5,0.6]$ & $0.64 * * *[0.5,0.7]$ & $0.65 * * *[0.6,0.8]$ \\
\hline Higher & $0.40 * * *[0.3,0.5]$ & $0.48 * * *[0.4,0.6]$ & $0.48 * * *[0.4,0.6]$ \\
\hline \multicolumn{4}{|l|}{ Wealth index(Reference category Poor) } \\
\hline Middle & & $0.64 * * *[0.7,0.8]$ & $0.65 * * *[0.6,0.8]$ \\
\hline Rich & & $0.47 * * *[0.5,0.6]$ & $0.48 * * *[0.4,0.6]$ \\
\hline \multicolumn{4}{|c|}{ HH size(Reference category HH size 3-4 members) } \\
\hline 5-6 members & & $1.11[1.0,1.4]$ & $1.10[1.0,1.3]$ \\
\hline 7-8 members & & $1.23 *[1.0,1.5]$ & $1.22 *[1.0,1.4]$ \\
\hline$>8$ members & & $1.19[1.0,1.5]$ & $1.17[1.0,1.4]$ \\
\hline \multicolumn{4}{|l|}{ Community Level Characteristics } \\
\hline \multicolumn{4}{|l|}{ Ethnicity(Refernececategory Urdu) } \\
\hline Punjabi & & $0.86[0.7,1.1]$ & $0.87[0.7,1.1]$ \\
\hline Saraikai & & $0.95[0.7,1.2]$ & $0.90[0.7,1.2]$ \\
\hline Others & & $1.08[0.8,1.4]$ & $1.08[0.8,1.4]$ \\
\hline \multicolumn{4}{|l|}{ Region (Reference category Urban) } \\
\hline Rural & $1.22 * * *[1.1,1.3]$ & $0.93[0.9,1.0]$ & $0.94[0.9,1.0]$ \\
\hline \multicolumn{4}{|c|}{ Sanitation facility(Reference category Unimproved) } \\
\hline Improved & & $0.86^{*}[0.7,1.0]$ & $0.87 *[0.8,1.0]$ \\
\hline \multicolumn{4}{|c|}{ Drinking water facility(Reference category Unimproved) } \\
\hline Improved & & $1.13[0.7,1.5]$ & $1.12[0.8,1.5]$ \\
\hline \multicolumn{4}{|c|}{ Water treatment(Reference category Treated) } \\
\hline Untreated & & $1.26[1.0,1.7]$ & $1.25[1.0,1.6]$ \\
\hline
\end{tabular}




\begin{tabular}{|c|c|c|c|c|}
\hline \multicolumn{5}{|c|}{ Moderate Stunting SD > -2 } \\
\hline Variables & Model $1^{\mathrm{a}}$ & Model $2^{b}$ OR $[95 \% \mathrm{CI}]$ & Model $3^{\mathrm{c}} \mathrm{OR}[95 \% \mathrm{CI}]$ & Model4 ${ }^{\mathrm{d}}$ OR $[95 \% \mathrm{CI}]$ \\
\hline \multicolumn{5}{|c|}{ Regional LevelCharacteristics } \\
\hline \multicolumn{5}{|c|}{ Food Insecurity index(Reference category Food Insecure) } \\
\hline Food Vulnerable & & & & $0.77 *[0.6,0.9]$ \\
\hline Food Secure & & & & $0.71 * * *[0.6,0.9]$ \\
\hline \multicolumn{5}{|c|}{ Division (Reference category Rawalpindi Division) } \\
\hline Bahawalpur & & & & $1.56^{*}[1.1,2.2]$ \\
\hline D.G Khan & & & & $1.51 *[1.0,2.2]$ \\
\hline Faisalabad & & & & $1.45^{* *}[1.1,1.9]$ \\
\hline Gujranwala & & & & $1.41 *[1.1,1.9]$ \\
\hline Lahore & & & & $1.88 * * *[1.3,2.7]$ \\
\hline Multan & & & & $1.41 *[1.1,1.9]$ \\
\hline Sahiwal & & & & $1.39 *[1.0,1.9]$ \\
\hline Sargodha & & & & $1.13[0.8,1.6]$ \\
\hline \multicolumn{5}{|c|}{ Variation at different levels } \\
\hline Level-1 (Household) & $1.18(0.10)^{* * *}$ & $2.19 * * *(1.2,3.7)$ & $2.17 * * *(1.3,3.7)$ & $2.18 * * *(1.3,3.7)$ \\
\hline Level-2 (Community) & $0.53(0,03)^{* * *}$ & $0.15 * * *(0.08,0.3)$ & $0.14 * * * 0.07,0.3)$ & $0.14 * * *(0.07,0.3)$ \\
\hline Level-3 (District) & $0.37(0.03)^{* * *}$ & $0.04 * * *(0.02,0.1)$ & $0.03 * * *(0.01,0.08)$ & $0.004(0.0,0.02)$ \\
\hline Chi2 & $(1005.94)^{* * *}$ & & & \\
\hline
\end{tabular}

OR = Odds Ratio, CI= 95\% Confidence Intervals in brackets. $* p<0.05, * * p<0.01$, *** $p<0.001$.

$a=$ base model (unconditional three level hierarchical model), $b=$ hierarchical model with child and parental characteristics, $c=$ hierarchical model with child, parental and household characteristics and $d=$ hierarchical model with child, parental, household and districts food insecurity index and division 
Table 5.3 Multivariable Regression results of Multilevel Models Punjab (MICS-2014)

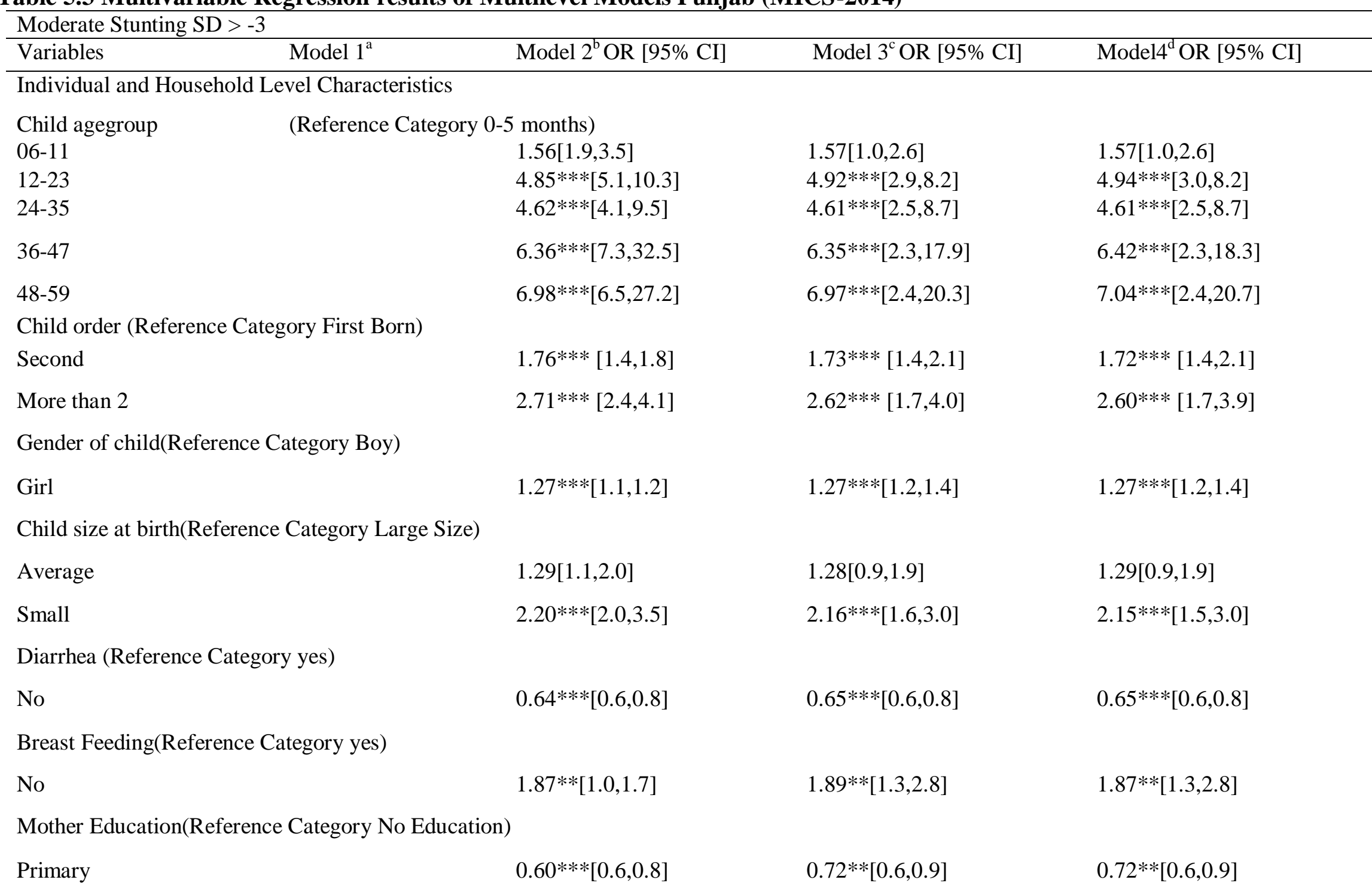




\begin{tabular}{|c|c|c|c|}
\hline \multicolumn{4}{|l|}{ Moderate Stunting SD > -3 } \\
\hline 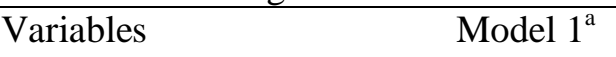 & Model $2^{b}$ OR $[95 \% \mathrm{CI}]$ & Model $3^{\mathrm{c}}$ OR $[95 \% \mathrm{CI}]$ & Model4 ${ }^{\mathrm{d}}$ OR $[95 \% \mathrm{CI}]$ \\
\hline Middle & $0.46^{* * *}[0.4,0.6]$ & $0.61 * * *[0.5,0.8]$ & $0.61 * * *[0.5,0.8]$ \\
\hline Secondary & $0.40 * * *[0.4,0.6]$ & $0.56 * * *[0.4,0.7]$ & $0.56 * * *[0.4,0.7]$ \\
\hline Higher & $0.22 * * *[0.2,0.3]$ & $0.31 * * *[0.2,0.5]$ & $0.31 * * *[0.2,0.5]$ \\
\hline \multicolumn{4}{|c|}{ Mother Age (Reference Category age of women<18 years of age) } \\
\hline Age $>=18 \&<=24$ & $0.99[0.7,1.2]$ & $1.03[0.8,1.3]$ & $1.03[0.8,1.3]$ \\
\hline Age $>24 \&<=35$ & $0.89[0.8,1.1]$ & $0.93[0.7,1.2]$ & $0.93[0.7,1.2]$ \\
\hline Age $>36$ & $0.92[0.7,1.0]$ & $0.93[0.7,1.2]$ & $0.93[0.7,1.2]$ \\
\hline \multicolumn{4}{|l|}{ Postnatal Care(Reference category yes) } \\
\hline No & $0.95[0.9,1.1]$ & $0.95[0.8,1.2]$ & $0.94[0.8,1.2]$ \\
\hline More than 4 visit & $0.99[0.8,1.0]$ & $1.06[0.9,1.3]$ & $1.07[0.9,1.3]$ \\
\hline \multicolumn{4}{|l|}{ Delivery place (Reference category Home) } \\
\hline Hospital & $0.96[0.8,1.1]$ & $1.02[0.8,1.3]$ & $1.03[0.8,1.3]$ \\
\hline \multicolumn{4}{|c|}{ Father education(Reference category No Education) } \\
\hline Primary & $0.80 *[0.7,1.0]$ & $0.86[0.7,1.0]$ & $0.87[0.7,1.0]$ \\
\hline Middle & $0.56 * * *[0.6,0.7]$ & $0.63 * * *[0.5,0.7]$ & $0.64 * * *[0.6,0.8]$ \\
\hline Secondary & $0.56 * * *[0.5,0.6]$ & $0.66 * * *[0.5,0.8]$ & $0.67 * *[0.5,0.9]$ \\
\hline Higher & $0.41 * * *[0.3,0.5]$ & $0.50 * * *[0.4,0.6]$ & $0.51 * * *[0.4,0.6]$ \\
\hline \multicolumn{4}{|l|}{ Wealth Index(Reference category Poor) } \\
\hline Middle & & $0.61 * * *[0.5,0.7]$ & $0.61 * * *[0.5,0.7]$ \\
\hline
\end{tabular}




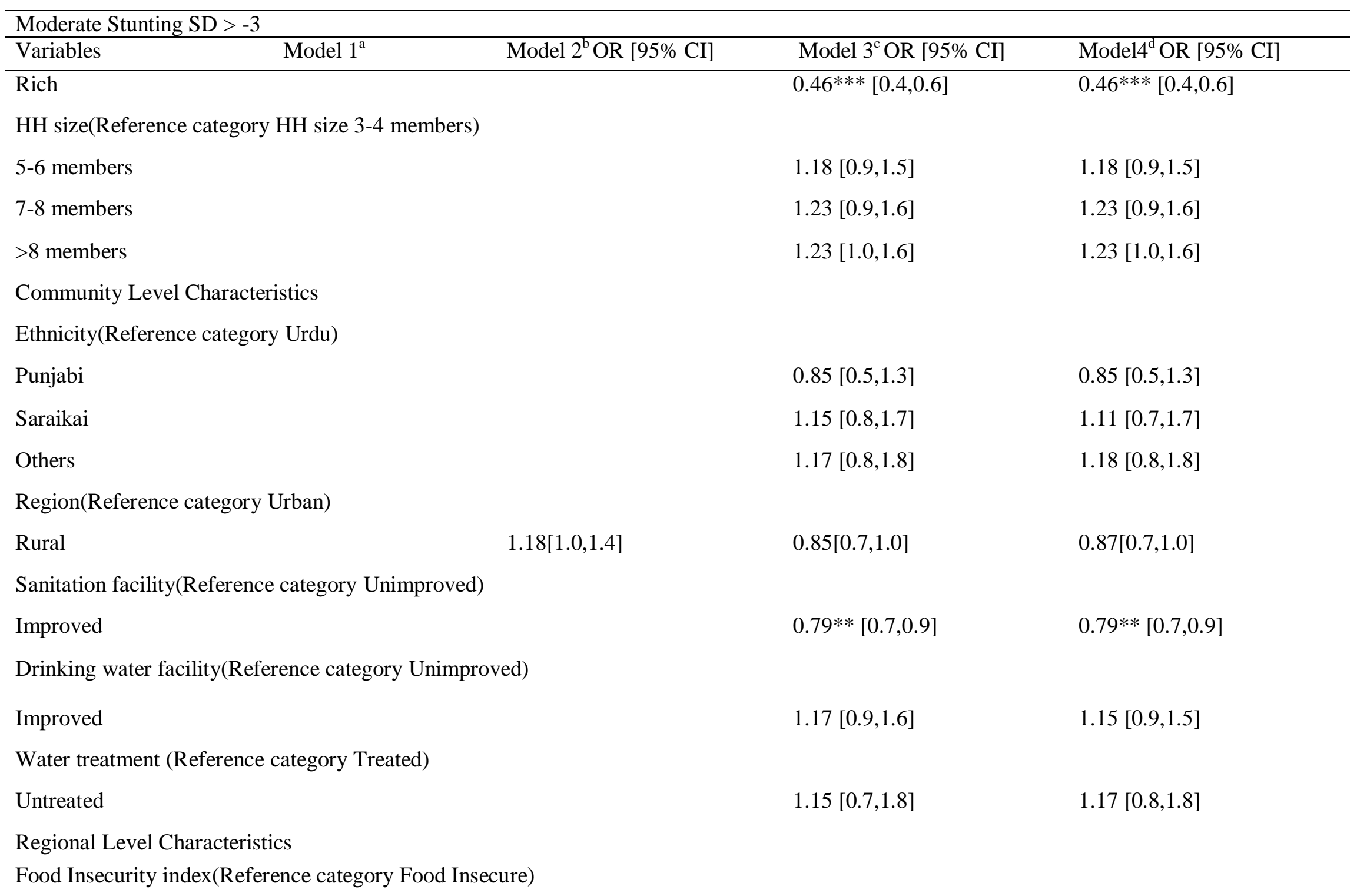




\begin{tabular}{|c|c|c|c|c|}
\hline \multicolumn{5}{|c|}{ Moderate Stunting SD > -3 } \\
\hline Variables & Model $1^{\mathrm{a}}$ & Model $2^{\mathrm{b}}$ OR $[95 \% \mathrm{CI}]$ & Model $3^{\mathrm{c}}$ OR $[95 \% \mathrm{CI}]$ & Model4 ${ }^{\mathrm{d}}$ OR [95\% CI] \\
\hline Food Vulnerable & & & & $0.87[0.6,1.2]$ \\
\hline Food Secure & & & & $0.77[0.6,1.1]$ \\
\hline \multicolumn{5}{|c|}{ Division (Reference category Rawalpindi Division) } \\
\hline Bahawalpur & & & & $1.57 *[1.0,2.4]$ \\
\hline D.G Khan & & & & $1.84 * *[1.2,2.9]$ \\
\hline Faisalabad & & & & $1.63^{*}[1.1,2.4]$ \\
\hline Gujranwala & & & & $1.60 *[1.0,2.5]$ \\
\hline Lahore & & & & $1.98 * *[1.2,3.2]$ \\
\hline Multan & & & & $1.41[0.9,2.1]$ \\
\hline Sahiwal & & & & $1.57 *[1.1,2.3]$ \\
\hline Sargodha & & & & $0.93[0.6,1.4]$ \\
\hline \multicolumn{5}{|c|}{ Variation at different level } \\
\hline Level-1 (Household) & $1.16(0.16)^{* * *}$ & $2.51 * * *(1.3,4.7)$ & $2.50 * * *(1.3,3.7)$ & $2.50 * * *(1.3,4.7)$ \\
\hline Level-2 (community) & $0.55(0.05)^{* * *}$ & $0.20 * * *(0.1,0.4)$ & $0.19 * * *(0.07,0.3)$ & $0.19 * * *(0.09 .0 .4)$ \\
\hline Level-3 (District) & $0.48(0.06)^{* * *}$ & $0.10 * * *(0.04,0.2)$ & $0.06^{* * *}(0.01,0.08)$ & $0.02 *(0.0,0.05)$ \\
\hline Chi2 & $(628.88)^{* * *}$ & & & \\
\hline
\end{tabular}


Table 5.4 Description of the Variance Partition Coefficient (VPC) and Intra Class Correlation (ICC)

\begin{tabular}{|c|c|c|c|c|c|c|c|c|}
\hline Models & \multicolumn{2}{|c|}{ Model 1} & \multicolumn{2}{|c|}{ Model 2} & \multicolumn{2}{|c|}{ Model 3} & \multicolumn{2}{|c|}{ Model 4} \\
\hline $\begin{array}{l}\text { Standard } \\
\text { Dev. }\end{array}$ & $-2 \mathrm{SD}$ & $-3 \mathrm{SD}$ & $-2 \mathrm{SD}$ & $-3 \mathrm{SD}$ & $-2 \mathrm{SD}$ & $-3 \mathrm{SD}$ & $-2 \mathrm{SD}$ & $-3 \mathrm{SD}$ \\
\hline \multicolumn{9}{|c|}{ Variance Partition Coefficient (VPC) } \\
\hline$V P C_{h h}$ & 0.56 & 0.53 & 0.92 & 0.89 & 0.927 & 0.90 & 0.938 & 0.92 \\
\hline$V P C_{\text {comm }}$ & 0.25 & 0.25 & 0.06 & 0.07 & 0.059 & 0.07 & 0.06 & 0.07 \\
\hline$V P C_{\text {distt }}$ & 0.17 & 0.22 & 0.016 & 0.035 & 0.01 & 0.02 & 0.002 & 0.007 \\
\hline \multicolumn{9}{|c|}{ Intra Class Correlation (ICC) } \\
\hline$I C C_{\text {comm }}$ & 0.43 & 0.47 & 0.096 & 0.106 & 0.07 & 0.09 & 0.06 & 0.07 \\
\hline$I C C_{\text {distt }}$ & 0.17 & 0.22 & 0.016 & 0.035 & 0.01 & 0.02 & 0.002 & 0.007 \\
\hline
\end{tabular}

Auther,s calculation 


\subsection{References}

Abuya, B.A., Ciera, J., Kimani-Murage, E., (2012).Effect of mother's education on child's nutritional status in the slums of Nairobi.BMC Pediatrics 12, 80.

Adekanmbi, V.T., Kayode, G.A., Uthman, O.A., (2013). Individual and contextual factors associated with childhood stunting in Nigeria: a multilevel analysis. Maternal and Child Nutrition 9, 244-259.

Aguayo, V.M., Badgaiyan, N., Paintal, K., (2015).Determinants of child stunting in the Royal Kingdom of Bhutan: an in-depth analysis of nationally representative data. Matern Child Nutr 11, 333-345.

Aguayo, V.M., Menon, P., (2016). Stop stunting: improving child feeding, women's nutrition, and household sanitation in South Asia. Maternal and Child Nutrition 12, 3-11.

Aheto, J.M.K., Keegan, T.J., Taylor, B.M. and Diggle, P.J., (2015). Childhood malnutrition and its determinants among under-five children in Ghana. Paediatric and perinatal epidemiology, 29(6), pp. 552-561.

Ahmed, T., Hossain, M., Mahfuz, M., Choudhury, N., Ahmed, S., 2016. Imperatives for reducing child stunting in Bangladesh. Maternal and Child Nutrition 12, 242-245.

Ahsan, K.Z., El Arifeen, S., Al-Mamun, M.A., Khan, S.H. and Chakraborty, N., (2017). Effects of individual, household and community characteristics on child nutritional status in the slums of urban Bangladesh. Archives of Public Health, 75(1), p.9.

Bhutta, Z.A., Gazdar, H. and Haddad, L., (2013). Seeing the unseen: breaking the logjam of undernutrition in Pakistan. IDS Bulletin, 44(3), pp. 1-9.

Black, R. E., Victora, C. G., Walker, S. P., Bhutta, Z. A., Christian, P., De Onis, M., and Uauy, R. (2013). Maternal and child undernutrition and overweight in low-income and middleincome countries. The lancet, 382(9890), 427-451.

Bongaarts, J., (2013). The implementation of preferences for male offspring. Population and Development Review, 39(2), pp.185-208.

Cheema, A., Khalid, L., and Patnam, M., (2008). The geography of poverty. Evidence from the Punjab. The Lahore Journal of Economics, 13, 163-188.

Chirande, L., Charwe, D., Mbwana, H., Victor, R., Kimboka, S., Issaka, A.I., Baines, S.K., Dibley, M.J. and Agho, K.E., (2015). Determinants of stunting and severe stunting 
among under-fives in Tanzania: evidence from the 2010 cross-sectional household survey. BMC pediatrics, 15(1), p. 165.

Chowdhury, M.R.K., Rahman, M.S., Khan, M.M.H., Mondal, M.N.I., Rahman, M.M., Billah, B., (2016). Risk Factors for Child Malnutrition in Bangladesh: A Multilevel Analysis of a Nationwide Population-Based Survey. The Journal of Pediatrics 172, 194-201.

Cumming, O., Cairncross, S., (2016). Can water, sanitation and hygiene help eliminate stunting? Current evidence and policy implications. Maternal and Child Nutrition 12, 91-105.

Das, J.K., Achakzai, A.B.K., Bhutta, Z.A., (2016). Stop stunting: Pakistan perspective on how this could be realized. Maternal and Child Nutrition 12, 253-256.

Deaton, A., and Drèze, J.,(2009). Food and nutrition in India: facts and interpretations. Economic and political weekly, 42-65.

Dewey, K.G., Begum, K., (2011). Long-term consequences of stunting in early life. Maternal and Child Nutrition 7, 5-18.

Dorsey, J.L., Manohar, S., Neupane, S., Shrestha, B., Klemm, R.D. and West, K.P., (2018). Individual, household, and community level risk factors of stunting in children younger than 5 years: Findings from a national surveillance system in Nepal. Maternal and child nutrition, 14(1).

Onis, M. and Branca, F., (2016). Childhood stunting: a global perspective. Maternal and child nutrition, 12(S1), pp. 12-26.

Fink, G., Günther, I. and Hill, K., (2011). The effect of water and sanitation on child health: evidence from the demographic and health surveys 1986-2007. International journal of epidemiology, 40(5), pp.1196-1204.

SDC, SDPI,WFP, (2009). Food Insecurity in Pakistan, Islamabad, Pakistan.

Gautam, K.P., Adhikari, M., Khatri, R.B. and Devkota, M.D., (2016). Determinants of infant and young child feeding practices in Rupandehi, Nepal. BMC research notes, 9(1), p. 135.

Gewa, C.A. and Yandell, N., (2012). Undernutrition among Kenyan children: contribution of child, maternal and household factors. Public health nutrition, 15(6), pp. 1029-1038.

Glewwe, P., (1999). Why does mother's schooling raise child health in developing countries? Evidence from Morocco. Journal of human resources, pp. 124-159. 
Grantham-McGregor, S., Cheung, Y.B., Cueto, S., Glewwe, P., Richter, L., Strupp, B. and International Child Development Steering Group, (2007). Developmental potential in the first 5 years for children in developing countries. The lancet, 369(9555), pp. 60-70.

Haile, D., Azage, M., Mola, T., Rainey, R., (2016). Exploring spatial variations and factors associated with childhood stunting in Ethiopia: spatial and multilevel analysis. $B M C$ Pediatrics ,16, 49.

Hazarika, G., 2000. Gender Differences in Children's Nutrition and Access to Health Care in Pakistan. The Journal of Development Studies 37, 73-92.

Hoddinott, J., Maluccio, J. A., Behrman, J. R., Flores, R., and Martorell, R. (2008). Effect of a nutrition intervention during early childhood on economic productivity in Guatemalan adults. The lancet, 371(9610), 411-416.

Horton, S., (1988). Birth order and child nutritional status: evidence from the Philippines. Economic Development and Cultural Change, 36(2), pp. 341-354.

Howell, E.M., Holla, N. and Waidmann, T., (2016). Being the younger child in a large African Family: a study of birth order as a risk factor for poor health using the demographic and health surveys for 18 countries. BMC Nutrition, 2(1), p. 61.

International Food Policy Research Institute. 2016. Global Nutrition Report 2016: From Promise to Impact: Ending Malnutrition by 2030. Washington, DC.

Jayachandran, S. and Pande, R., (2017). Why are Indian children so short? The role of birth order and son preference. American Economic Review, 107(9), pp. 2600-2629.

Joe, W., Rajaram, R. and Subramanian, S.V., (2016).Understanding the null-to-small association between increased macroeconomic growth and reducing child undernutrition in India: role of development expenditures and poverty alleviation. Maternal and child nutrition, 12(S1), pp.196-209.

Kavosi, E., Hassanzadeh Rostami, Z., Kavosi, Z., Nasihatkon, A., Moghadami, M., Heidari, M., (2014). Prevalence and determinants of under-nutrition among children under six: a cross-sectional survey in Fars province, Iran. Int J Health Policy Manag 3, 71-76.

Khalid, H. and Martin, E.G., (2017). Female-Headed Households Associated with Lower Childhood Stunting Across Culturally Diverse Regions of Pakistan: Results from a Cross-Sectional Household Survey. Maternal and child health journal, 21(10), pp.19671984. 
Khan, J.R., Awan, N. and Misu, F., (2016). Determinants of anemia among 6-59 months aged children in Bangladesh: evidence from nationally representative data. BMC pediatrics, 16(1), p.3.

Khuwaja, S., Selwyn, B.J., Shah, S.M., (2005).Prevalence and Correlates of Stunting among Primary School Children in Rural Areas of Southern Pakistan. J Trop Pediatr 51, 72-77.

Kreft, I.G., Kreft, I. and de Leeuw, J., (1998). Introducing multilevel modeling.Sage.

Menon, P., (2012). Childhood Undernutrition in South Asia: Perspectives from the Field of Nutrition. CESifo Econ Stud 58, 274-295.

Mushtaq, M.U., Gull, S., Khurshid, U., Shahid, U., Shad, M.A., Siddiqui, A.M., (2011). Prevalence and socio-demographic correlates of stunting and thinness among Pakistani primary school children. BMC Public Health 11, 790.

Nkurunziza, S., Meessen, B. and Korachais, C., (2017). Determinants of stunting and severe stunting among Burundian children aged 6-23 months: evidence from a national crosssectional household survey, 2014. BMC pediatrics, 17(1), p.176.

Nuruddin, R., Hadden, W.C., 2015. Are pre-school girls more likely to be under-nourished in rural Thatta, Pakistan?-a cross-sectional study. International Journal for Equity in Health $14,151$.

Pakistan Demographic and Health Survey (PDHS), 2012-13. ICF International USA: 2013.

Rahman, M.S., Howlader, T., Masud, M.S. and Rahman, M.L., (2016). Association of low-birth weight with malnutrition in children under five years in Bangladesh: Do mother's education, socio-economic status, and birth interval matter?.PloS one, 11(6), e0157814.

Raju, D. and Dsouza, R., (2017). Child undernutrition in Pakistan: what do we know?.

Rakotomanana, H., Gates, G., Hildebrand, D. and Stoecker, B.J., (2016). The Determinants of Stunting in Children under Five in Madagascar. The FASEB Journal.

Schwarz, N. G., Grobusch, M. P., Decker, M. L., Goesch, J., Poetschke, M., Oyakhirome, S., ... and Kremsner, P. G. (2008). WHO 2006 child growth standards: implications for the prevalence of stunting and underweight-for-age in a birth cohort of Gabonese children in comparison to the Centers for Disease Control and Prevention 2000 growth charts and the National Center for Health Statistics 1978 growth references. Public health nutrition, 11(7), 714-719. 
Shah, S.M., Selwyn, B.J., Luby, S., Merchant, A., Bano, R., (2003). Prevalence and correlates of stunting among children in rural Pakistan. Pediatrics International 45, 49-53.

Sharaf, M.F., Mansour, E.I. and Rashad, A.S., (2018). Child nutrition status in Egypt. A comprehensive analysis of socioeconomic determinants using a quantile regression approach. Journal of biosocial science, pp.1-17.

Shinsugi, C., Matsumura, M., Karama, M., Tanaka, J., Changoma, M. and Kaneko, S., (2015). Factors associated with stunting among children according to the level of food insecurity in the household: a cross-sectional study in a rural community of Southeastern Kenya. BMC public health, 15(1), p.441.

Smith, L. C., \& Haddad, L. (2015). Reducing child undernutrition: past drivers and priorities for the post-MDG era. World Development, 68, 180-204.

Snijders, T. and Bosker, R., (1999). Multilevel modeling: An introduction to basic and advanced multilevel modeling.

Som, S., Pal, M., Bharati, D.P., (2007). Role of individual and household level factors on stunting: A comparative study in three Indian states. Annals of Human Biology 34, 632646.

How much international variation in child height can sanitation explain? (2013) World Bank policy research working paper, no WPS 6351 http://go.worldbank.org/SZE5WUJBI0

Tiwari, R., Ausman, L.M., Agho, K.E., (2014). Determinants of stunting and severe stunting among under-fives: evidence from the 2011 Nepal Demographic and Health Survey. BMC Pediatrics 14, 239.

Torlesse, H., Cronin, A.A., Sebayang, S.K. and Nandy, R., (2016). Determinants of stunting in Indonesian children: evidence from a cross-sectional survey indicate a prominent role for the water, sanitation and hygiene sector in stunting reduction. BMC public health, 16(1), p.669.

United Nations Children's Fund. (2015). State of the World's Children Statistical Report, UNICEF, New York.

United Nations Children's Fund. (2014). The state of the world's Children 2014, UNICEF, 2014, New York, NY.

United Nations Children's Fund. (2013). Improving Child Nutrition. The Achievable Imperative for Global Pregress, UNICEF, New York. 
United Nations Children's Fund. (2013). Monitoring the situation of women and children. Statistics by Area, Child Nutrition.

UNSCN (2010) Sixth report on the world nutrition situation United Nations System Standing Committee on Nutrition, Geneva.

Victora, C.G., de Onis, M., Hallal, P.C., Blössner, M. and Shrimpton, R., (2010).Worldwide timing of growth faltering: revisiting implications for interventions. Pediatrics, pp. peds2009.

Vollmer, S., Bommer, C., Krishna, A., Harttgen, K. and Subramanian, S.V., (2016). The association of parental education with childhood undernutrition in low-and middleincome countries: comparing the role of paternal and maternal education. International journal of epidemiology, 46(1), pp.312-323.

Vollmer, S., Harttgen, K., Subramanyam, M. A., Finlay, J., Klasen, S., \& Subramanian, S. V. (2014). Association between economic growth and early childhood undernutrition: evidence from 121 Demographic and Health Surveys from 36 low-income and middleincome countries. The lancet global health, 2(4), e225-e234.

WHO: Physical Status: The Use and Interpretation of Anthropometry. WHO Technical Report Series, 854, WHO, Geneva (1995).

World Health Organization (WHO), (2006). Child growth standards: implications for the prevalence of stunting and underweight-for-age in a birth cohort of Gabonese children in comparison to the Centers for Disease Control and Prevention 2000 growth charts and the National Center for Health Statistics 1978 growth references. Public Health Nutrition 11, 714-719.

World Health Organization (WHO), (2006). Multi Center Growth Reference Study Group. WHO child growth standards based on length/height, weight and age. Acta Paediatrica 95. 


\section{Chapter 6 Conclusion and Policy Recommendations}

This dissertation focuses on major socioeconomic problems of Pakistan such as poverty, gender differences, food insecurity and malnutrition. First, we compare objective poverty with subjective poverty. Second, we investigate the gender differences in subjective wellbeing. Third, we analyze the correlates of food insecurity. Fourth, we examine the main determinants of stunting, which is one of the major malnutrition problems in Pakistan.

Chapter 2, analysis the determinants of subjective poverty and compare it with the objective poverty. Particularly we compared the determinants of subjective poverty and objective poverty with the poverty line of $\$ 1.25$ and $\$ 1$ per day. The findings of subjective poverty approach complement the objective poverty, but the subjective poverty has more broad contents. We have contradictory findings for some of their determinants; such as household size, gender classification, physical and food insecurity and regional domains.

Chapter 3 investigates the determinants of subjective well-being of both male and female within household as well as intra-household gender differences in subjective well-being in detail. For this purpose, the study unpacks many demographic and socio-economic factors that predict male-female discrepancy in reporting subjective well-being. Gender systems are likely to have a pivotal influence on individual well-being. The gender difference in wellbeing results delineate that individual specific predictors play their part in the deviation or generating the gender gap in their subjective well-being. Moreover, food insecurity imparts more negative impact on female subjective well-being, whereas, physical insecurity is mainly concerned with male subjective well-being.

Chapter 4 examines the determinants of household food insecurity in Pakistan. For this purpose, the household head asked about their multidimensional nature of household food insecurity situation. The results indicate that household per capita consumption, household education, gender, household size, household asset, borrowing, shocks, violence, and high inflation are the important determinants of food insecurity. Importantly, household income and food security are positively related while negative trend between food security and inflationary shocks. This study varies in some determinants, when compare with conventional measure of food insecurity. Specifically, the study finds that with increase in household size, the likelihood of food insecurity falls. Similarly, the household headed by female is more food insecure. The incidence of shock on agriculture land is severe, which in turn exacerbate 
household food insecurity. Moreover, as the terrorist activities climb up district wise, the probability of food insecurity also increases.

Chapter 5 analyzed the determinants of under nutrition (stunting) in Punjab Pakistan which consists of 25,067 children of less than five years. Moreover, the study uses multilevel hierarchical model at household, community and district level to capture the variation at various level of hierarchy. The findings confirm that the child specific, household, and district characteristics have strong predicting power in the explanation of stunting. Furthermore, the results also reveal that stark variation exist at household level, while at the community and district level the variances decrease as we incorporate the explanatory variables. Similarly, the results indicate that stunting and severe stunting is a daunting public health challenge of the province of Punjab, Pakistan because almost one fourth (27.4) percent children are moderately stunted and $10 \%$ are severely stunted in 2014 . This number is alarming. The key individual and household level covariates significantly associated with stunting and severe stunting are; age of child, birth order of child, being female, being smaller in size at birth, episode of diarrhea, breast feeding, mother and father education, and wealth status of household.

From policy perspective, poverty, gender differences, food insecurity and malnutrition are the major public policy challenges in Pakistan. Therefore, it is pivotal to consider the subjective measure of poverty while measuring poverty because categorization of subjective poor captures well the impact of specific determinants. Similarly categorization of gender on subjective economic grounds capture well the impact of specific determinants as well. The gender gap can be narrowed down by making and implementing policies related to gender specific access to goal relevant resources. For example, human development indicator such as education and a pressing public health concern such as food insecurity, significantly affects female well-being. Therefore, the public programs such as rural education, housing policy, food policy, and security level should be in line with these findings. Also, need to create opportunities for the female such as education, right of inheritance, employment to come at par with their male counterpart. The study also suggests that it is not safe to rely on only one dimension to measure well-being. Similarly, increasing household income is inevitable, particularly of the lower income brackets, which are highly vulnerable to poverty, food insecurity as well as malnutrition. The short-term solution would be the provision of national food safety net program. The long run solution lies in the economic growth and equitable distribution of land and resources, which not only ensure higher income but also create opportunities for the poor to gain access to nutrition, health, education, and employment. 
Thus, the findings have strong policy implication, indicating focus should be on the household, as stark income disparities exist among households.

Eradicating poverty and achieving food security remain a critical objective of development in Pakistan. Pakistan spends only 0.18 percent of agriculture GDP on agricultural R\& D. This should be at least at par with the neighboring countries. Similarly, the importance of agribusiness should be streamline. Creation of opportunities and promotion of low cost microfinance, particularly among rural population should be the priority from the policy perspective. Importantly, education is critical for the farmers to adopt improved farming practices. The government need to take measures to improve the livelihood of farmers, particularly, changes in its production system. Conflicts, natural disasters, and migration are critical for food security and nutrition, so collaboration with national and international agencies in conflict affected and disaster hit areas should be encouraged.

The findings of the study are useful for setting up policy priorities as well as formulating poverty reduction strategies and multi-sectoral nutrition programs for achieving sustainable development goals related to poverty, nutrition, and hunger. In addition, this study set up the stage for debate as the year 2018 is election year and this study is baseline for setting up political and public policy priorities for overcoming the challenges of poverty, gender differences, food insecurity and malnutrition in Pakistan. 